\title{
DESCRIPTIONS OF REPRESENTATIVE CONTAMINATED SITES AND FACILITIES WITHIN THE DOE COMPLEX
}
S. M. Short
J. W. Buck
L. L. Clark
J. F. Fletcher
C. S. Glantz
G. R. Holdren

L. R. Huesties

L. Oates ${ }^{(a)}$

J. Reisenauer ${ }^{(a)}$

G. Whelan

M. D. Williams

October 1994

Prepared for

the U.S. Department of Energy

under Contract DE-AC06-76RLO 1830

Pacific Northwest Laboratory

Richland, Washington 99352

(a) ICF, Richland, Washington. 


\section{DISCLAIMER}

This report was prepared as an account of work sponsored by an agency of the United States Government. Neither the United States Government nor any agency thereof, nor any of their employees, make any warranty, express or implied, or assumes any legal liability or responsibility for the accuracy, completeness, or usefulness of any information, apparatus, product, or process disclosed, or represents that its use would not infringe privately owned rights. Reference herein to any specific commercial product, process, or service by trade name, trademark, manufacturer, or otherwise does not necessarily constitute or imply its endorsement, recommendation, or favoring by the United States Government or any agency thereof. The views and opinions of authors expressed herein do not necessarily state or reflect those of the United States Government or any agency thereof. 


\section{DISCLAIMER}

Portions of this document may be illegible in electronic image products. Images are produced from the best available original document. 


\section{SUMMARY}

The U.S. Department of Energy (DOE) has initiated efforts to prepare a Programmatic Environmental Impact Statement (PEIS) that will analyze the existing environmental restoration and waste management program and evaluate alternatives for an integrated program. The alternatives being evaluated include 1) a "No Action" alternative as required by the National Environmental Policy Act (NEPA), 2) an Applicable, Relevant, and Appropriate Requirements (ARAR)-driven alternative, 3) a land-use-driven alternative, 4) a health-risk-driven alternative, and 5) a combination land-use and health-risk-driven alternative.

The analytical approach being taken to evaluate each of these alternatives is to perform a remedial engineering analysis and human health and ecosystem effects analyses on every contaminated site and facility in the DOE complex. One of Pacific Northwest Laboratory's (PNL) (a) roles in this approach has been to compile the source term and environmental setting data needed to drive each of these analyses. To date, over 10,000 individual contaminated sites and facilities located throughout the DOE complex of installations have been identified and at least some minimal data compiled on each.

The PEIS analyses have been appreciably simplified by categorizing all of these contaminated sites and facilities into six broad categories: 1) contaminated

(a) Pacific Northwest Laboratory is operated for the U.S. Department of Energy by Battelle Memorial Institute under Contract DE-AC06-76RLO 1830. 
buildings, 2) contaminated soils, 3) solid waste sites (e.g., burial grounds), 4) liquid containment structures (e.g., tanks), 5) surface water sites, and 6) contaminated groundwater sites. A report containing a complete description of each of these thousands of contaminated sites and facilities would be tremendously large and unwieldy, as would separate reports describing the application of the analytical methodologies to each.

This report, therefore, provides descriptions of just eleven typical environmental restoration problems that DOE faces. These example situations are being used in the PEIS to demonstrate how the remedial engineering analysis and health and ecological effects analyses are being conducted on the thousands of contaminated sites and facilities for each of the alternatives identified previously. At least one example has been provided for each of the six above-described categories. A list of these example sites and facilities is provided in Table S.1. The first 10 example sites listed are described in Section 3 of this report and are being used to demonstrate the PEIS analyses. The eleventh example site is described in the appendix, separate from the other 10 example sites, because schedule constraints may prevent this site from actually being used as a demonstration site.

The results of the analyses on each of these example sites are being documented in separate reports. Volume I of this report series provides a summary of the results and conclusions and is being prepared by a company named META. Volume II (this report) provides descriptions of each of the example sites being analyzed. Volume III, which is being prepared by Louis Berger \& Associates, provides the engineering and labor-hour requirements. The final volume, 
TABLE S.1. List of Illustrative Examples

\begin{tabular}{||l|l||}
\hline \multicolumn{1}{|c|}{ Site/Facility Category } & \multicolumn{1}{c|}{ Brief Description of Site/Facility } \\
\hline Contaminated Soil & Cs-137-contaminated soil site \\
\hline Surface Water & Chemically contaminated man-made pond \\
\hline Groundwater & Radioactively/chemically contaminated aquifer \\
\hline Solid Waste Sites & Chemical waste disposal shaft \\
\hline & Low-level radioactive waste burial pit \\
\hline Facilities & Chemically contaminated office/storage building \\
\hline & Plutonium separations plant \\
\hline & Plutonium production reactor \\
\hline Liquid Containment Structures & Low-level liquid waste concrete holding pond \\
\hline & Low-level liquid waste underground storage tank \\
\hline Contaminated Soil & Actinide-contaminated soil site \\
\hline
\end{tabular}

Volume IV, is being prepared by Oak Ridge National Laboratory and provides detailed results of the baseline, worker, and post-remedial risk assessments for each of the example sites. 


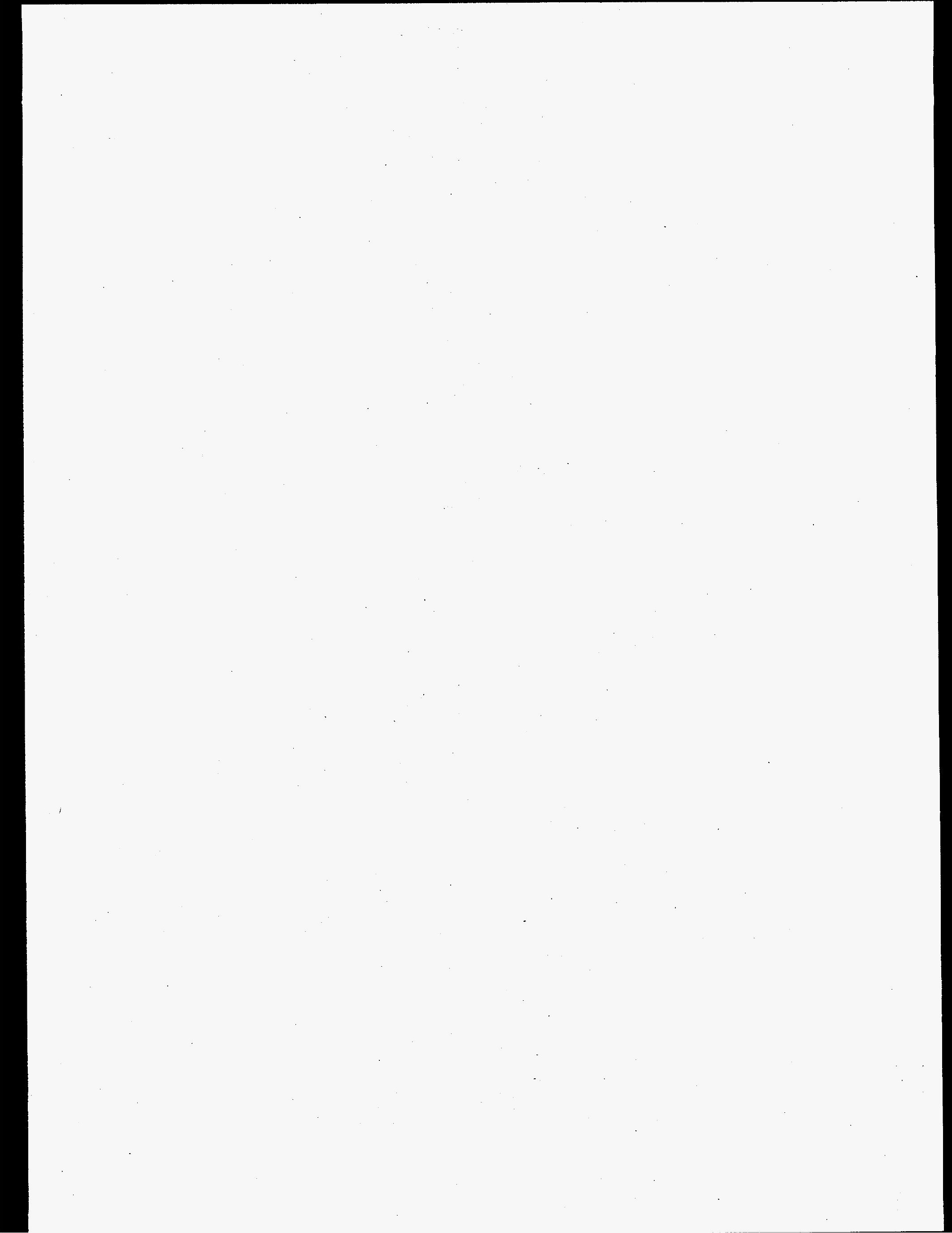




\section{CONTENTS}

SUMMARY $\ldots \ldots \ldots \ldots \ldots \ldots \ldots \ldots \ldots \ldots \ldots \ldots \ldots \ldots \ldots \ldots \ldots$

ACRONYMS

xxi

1: INTRODUCTION $\ldots \ldots \ldots \ldots \ldots \ldots \ldots \ldots \ldots \ldots \ldots \ldots$

1.1 Description Of The Peis Alternatives

1.2 SOURCE TERM DESCRIPTION TASK

2: $\quad$ APPROACH $\ldots \ldots \ldots \ldots \ldots \ldots \ldots \ldots \ldots \ldots \ldots \ldots \ldots \ldots \ldots \ldots$

2.1 Source Term Characteristics Data

2.2 Environmental SetTIng DATA $\ldots \ldots \ldots \ldots \ldots$

2.3 Representative Contaminated Sttes AND Faciltties

3: DESCRIPTIONS OF 10 EXAMPLE CONTAMINATED SITES AND BUILDINGS

3.1 Cesium-137-Contaminated Soll SIte $\ldots \ldots \ldots \ldots \ldots \ldots$

3.2 SURface Water Site $\ldots \ldots \ldots \ldots \ldots \ldots \ldots \ldots$

3.3 Groundwater StTE $\ldots \ldots \ldots \ldots \ldots \ldots \ldots \ldots$ 


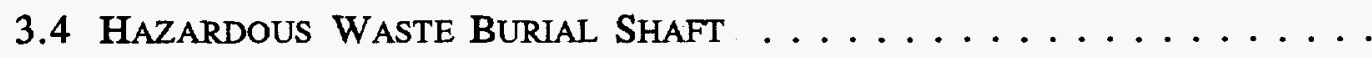

3.5 Radioactive Waste BuRIal PIT $\ldots \ldots \ldots \ldots \ldots \ldots$

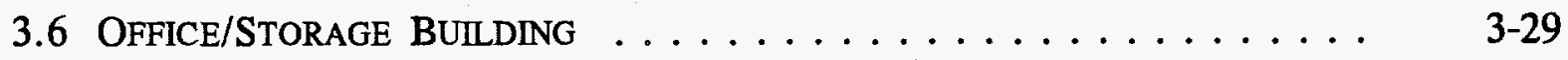

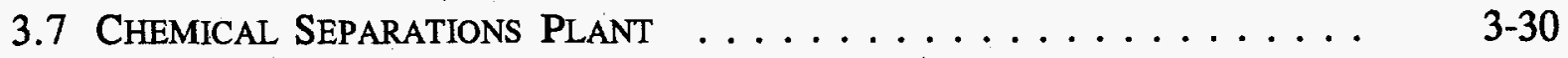

3.7.1 Canyon Processing Cells ................. 3-39

3.7.2 Pipe Tunnel and Air Tunnel . . . . . . . . . . . . . 3-45

3.7 .3 Canyon Galleries . . . . . . . . . . . . . . . 3-47

3.7 .4 Upper Canyon $\ldots \ldots \ldots \ldots \ldots \ldots \ldots \ldots \ldots$. . . . . . . . . . . . . .

3.7.5 Tower Extraction Column Shaft .............. 3-53

3.7.6 Tower Column Makeup and Operating Facilities . . . . . . . 3-57

3.7.7 Canyon East End Facilities . . . . . . . . . . . . . 3-60

3.7 .8 Service Wings $\ldots \ldots \ldots \ldots \ldots \ldots \ldots \ldots . \ldots \ldots$ 3. . . . . . . . .

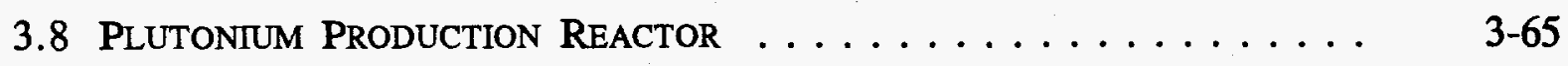

3.8.1 Reactor Graphite Stack . . . . . . . . . . . . . 3-72

3.8.2 Reactor Thermal Shield . . . . . . . . . . . . 3-76 
3.8.3 Reactor Biological Shield . . . . . . . . . . . . . 3-78

3.8.4 Reactor Process Tubes .................. 3- 30

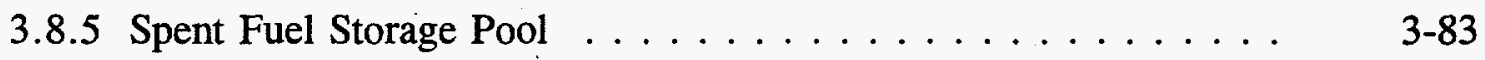

3.8.6 Reactor Control System .................. 3-86

3.8.7 Other Sub-Facilities in the Reactor . . . . . . . . . . 3-88

3.8.8 Hazardous and Mixed Waste Materials . . . . . . . . . 3-88

3.9 Concrete Holding Pond . . . . . . . . . . . . . . . 3-90

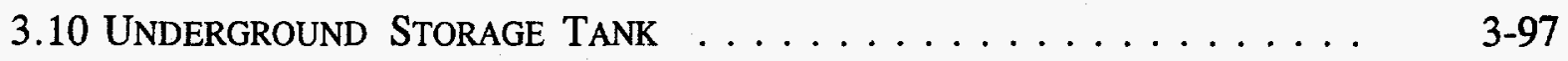

4: DESCRIPTION OF ENVIRONMENTAL SETTINGS $\ldots \ldots \ldots \ldots$. . . . . 4-1

4.1 OAK RIDGE NATIONAL LABORATORY . . . . . . . . . . . . 4-1

4.2 Pinellas Plant $\ldots \ldots \ldots \ldots \ldots \ldots \ldots \ldots \ldots \ldots$

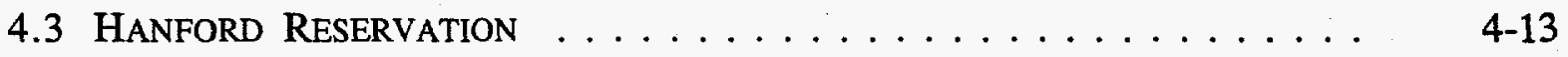

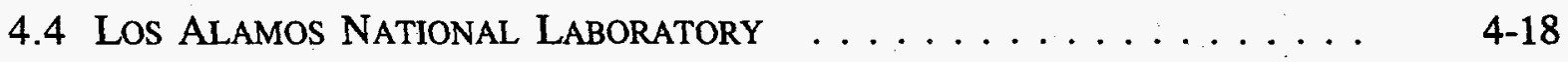

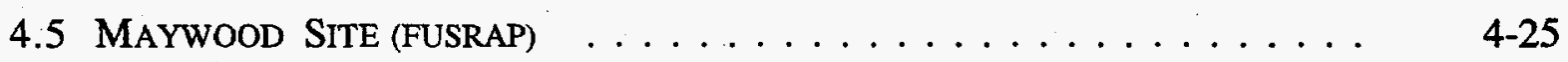

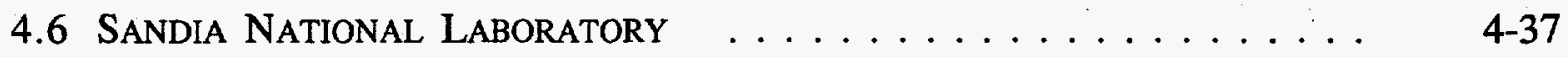


APPENDIX A: DESCRIPTION OF $11^{\mathrm{TH}}$ EXAMPLE SITE $\ldots \ldots \ldots \ldots$

A-1 


\section{FIGURES}

1.1 Approach to Technical Analysis of PEIS Alternatives . . . . . . . . . 1-4

3.1 Location of the Experimental Area $\ldots \ldots \ldots \ldots$ 3-3

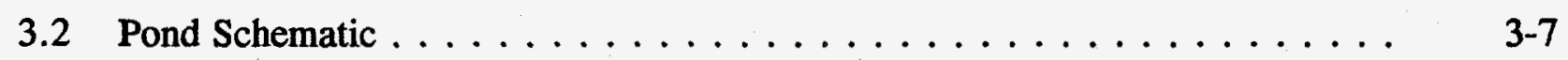

3.3 Groundwater Contours for the Cyanide Plume ............... 3-11

3.4 Groundwater Contours for the Fluoride Plume . . . . . . . . . . . . 3-12

3.5 Groundwater Contours for the Chromium Plume . . . . . . . . . . . 3-13

3.6 Groundwater Contours for the Carbon Tetrachloride Plume . . . . . . . 3-14

3.7 Groundwater Contours for the Chloroform Plume . . . . . . . . . . 3-15

3.8 Groundwater Contours for the Trichloroethylene Plume . . . . . . . . 3-16

3.9 Groundwater Contours for the Nitrate Plume $\ldots \ldots \ldots \ldots \ldots$. . . . . . .

3.10 Groundwater Contours for the Technetium-99 Plume $\ldots \ldots \ldots \ldots$. . . . . 38

3.11 Groundwater Contours for the Iodine-129 Plume . . . . . . . . . . . . 3-19

3.12 Groundwater Contours for the Uranium Plume . . . . . . . . . . . . . 3-20 
3.13 Inactive Pit, Impoundments, and Shafts at the Burial Grounds

3.14 Location and Approximate Site of Burial Pit $1 \ldots \ldots \ldots$

3.15 Plan View of the Office/Storage Building $\ldots \ldots \ldots \ldots$

3.16 Location of Chemical Separations Building Relative to Other Buildings

3.17 Cutaway View of the Chemical Separations Building $\ldots \ldots \ldots \ldots$

3.18 Plan View of Process Cells

3.20 View of Reactor Block Construction $\ldots \ldots \ldots \ldots \ldots$

3.21 Hot Pond and Surrounding Area

4.1 Location of the Oak Ridge National Laboratory $\ldots \ldots \ldots \ldots \ldots$

4.2 Location of the Pinellas Plant $\ldots \ldots \ldots \ldots \ldots \ldots$ 
4.4 Location of the Los Alamos National Laboratory . . . . . . . . . . . . . .

4.5 Location of the Maywood Site $\ldots \ldots \ldots \ldots \ldots \ldots \ldots \ldots \ldots$ 4. . . . . . . .

4.6 Location of the Sandia National Laboratory's Technical and Test Areas Within Kirtland Air Force Base . . . . . . . . . . . . 4-38

A.1 Location of the Actinide-Contaminated Soil Site $\ldots \ldots \ldots \ldots$ A-3

A.2 Approximate Areal Extent and Depth of Radiological Contamination . . . . A-5 


\section{TABLES}

S.1 List of Illustrative Examples $\ldots \ldots \ldots \ldots \ldots \ldots \ldots$

1.1 DOE Installations Included in Analysis $\ldots \ldots \ldots \ldots$ 1-6

3.1 Physical Description of Cs-137 Contaminated Soil Site . . . . . . . . . 3-4

3.2 Description of Waste Constituents Released at Experimental Site . . . . . . . 3-5

3.3 Vertical Distribution of Cs-137 in the Soil Column for the

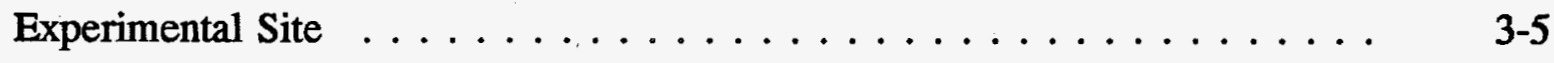

3.4 Description of the Pond $\ldots \ldots \ldots \ldots \ldots \ldots$

3.5 Contaminants Measured in the Pond $\ldots \ldots \ldots \ldots \ldots$

3.6 Contaminants Measured in the Groundwater . . . . . . . . . . . . . 3-10

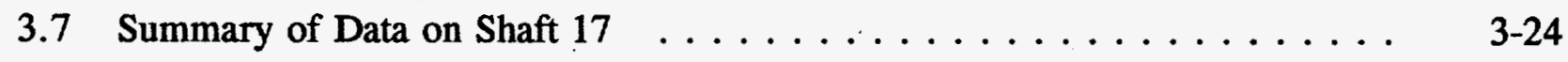

3.8 Estimated Inventory of Contaminants in Shaft $17 \ldots \ldots \ldots$

3.9 Physical Characteristics of Burial Pit $1 \ldots \ldots \ldots \ldots \ldots$ 3-28

3.10 Estimate of Contaminant Inventories in Burial Pit $1 \ldots \ldots$. . . . . . . 3-29

3.11 Physical Description of the Office/Storage Building . . . . . . . . 3-30 
3.12 Physical Description of the Chemical Separations Plant $\ldots \ldots \ldots \ldots$ 3-35

3.13 Principal Contaminants in the Chemical Separations Plant $\ldots \ldots \ldots \ldots$ 3-40

3.14 Physical Description of the Canyon Process Cells $\ldots \ldots \ldots \ldots$ 3-43

3.15 Principal Contaminants in Canyon Process Cells $\ldots \ldots \ldots \ldots \ldots . . . .4-44$

3.16 Physical Description of the Canyon Tunnels $\ldots \ldots \ldots \ldots \ldots \ldots$ 3-46

3.17 Principal Contaminants in the Pipe and Exhaust Air Tunnels . . . . . . 3-47

3.18 Physical Description of the Canyon Galleries $\ldots \ldots \ldots \ldots$ 3-49 . . . .

3.19 Principal Contaminants in Canyon Galleries $\ldots \ldots \ldots \ldots \ldots \ldots \ldots$ 3-50

3.20 Physical Description of the Upper Canyon $\ldots \ldots \ldots \ldots \ldots \ldots \ldots$. $\ldots \ldots 2$

3.21 Principal Contaminants in Upper Canyon $\ldots \ldots \ldots \ldots \ldots \ldots . . \ldots \ldots$

3.22 Physical Description of the Tower Extraction Column Shaft $\ldots \ldots \ldots \ldots$ 3-55

3.23 Principal Contaminants in Column Shaft $\ldots \ldots \ldots \ldots \ldots \ldots . \ldots \ldots$ 3-57

3.24 Physical Description of the Tower Column Makeup and Operating Facilities $\ldots \ldots \ldots \ldots \ldots \ldots \ldots \ldots \ldots \ldots \ldots$ 3-59

3.25 Principal Contaminants in Tower Column Makeup and Operating Facilities $\ldots \ldots \ldots \ldots \ldots \ldots \ldots \ldots \ldots$ 
3.26 Physical Description of the East End Facilities $\ldots \ldots \ldots \ldots$ 3-63

3.27 Principal Contaminants in East End Facilities $\ldots \ldots \ldots \ldots \ldots \ldots$ 3-64

3.28 Physical Description of the Reactor Building $\ldots \ldots \ldots \ldots \ldots \ldots \ldots$ 3-71

3.29 Total Content of Radionuclides in the Reactor Building $\ldots \ldots \ldots$ 3-73

3.30 Total Content of Chemical Contaminants $\ldots \ldots \ldots \ldots \ldots$ 3-73

3.31 Description of the Reactor Graphite Stack $\ldots \ldots \ldots \ldots \ldots$ 3-75

3.32 Principal Contaminants in Graphite Stack $\ldots \ldots \ldots \ldots \ldots$ 3-75

3.33 Description of Reactor Thermal Shield $\ldots \ldots \ldots \ldots \ldots \ldots \ldots$ 3-77

3.34 Principal Contaminants in Thermal Shield $\ldots \ldots \ldots \ldots \ldots$ 3-78

3.35 Description of the Biological Shield $\ldots \ldots \ldots \ldots \ldots \ldots \ldots \ldots$ 3-80

3.36 Principal Contaminants in Biological Shield $\ldots \ldots \ldots \ldots \ldots \ldots \ldots$ 3-81

3.37 Description of the Process Tube Assemblies . . . . . . . . . . 3-82

3.38 Principal Contaminants in Process Tube Assemblies $\ldots \ldots \ldots \ldots$. . . . . .

3.39 Description of the Spent Fuel Storage Pool $\ldots \ldots \ldots \ldots \ldots \ldots$ 3-84

3.40 Principal Contaminants in the Spent Fuel Storage Pool $\ldots \ldots \ldots \ldots$ 3-85 
3.41 Description of the Reactor Control System $\ldots \ldots \ldots$. . . . . . . . . .

3.42 Principal Contaminants in the Reactor Control System . . . . . . . . 3-88

3.43 Lead and Cadmium Located in Reactor Building . . . . . . . . . 3-89

3.44 Lead and Cadmium in Reactor Building . . . . . . . . . . . . . 3-90

3.45 Description of Hot Pond $\ldots \ldots \ldots \ldots \ldots \ldots \ldots \ldots$

3.46 Residual Contaminants in the Concrete $\ldots \ldots \ldots \ldots$ 3-93

3.47 Description of Contaminants in the Soil . . . . . . . . . . . . 3-95

3.48 Vertical Distribution of Contaminants in the Soil Column Beneath the Hot Pond . . . . . . . . . . . . . . . . . . . . . 266

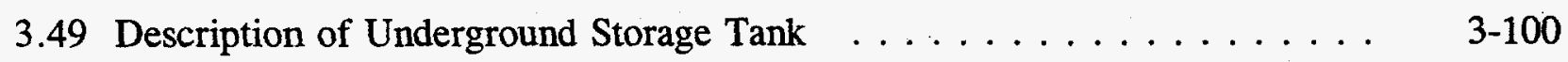

3.50 Description of Contaminants in Tank Sludge . . . . . . . . . . . . 3-101

4.1 ORNL Average Local Climatology $\ldots \ldots \ldots \ldots \ldots \ldots$

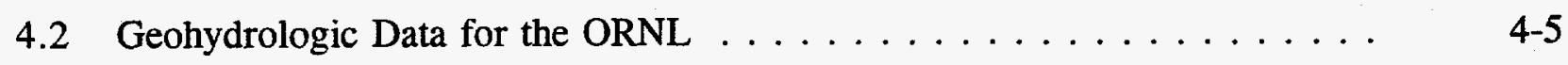

4.3 Exposure Data for the ORNL $\ldots \ldots \ldots \ldots \ldots \ldots$

4.4 ORNL Population Distribution for Atmospheric Pathway $\ldots \ldots \ldots$. . . . . 
4.5 Distribution of Agriculture Products Around the ORNL . . . . . . . . 4 4-8

4.6 Pinellas Plant Average Local Climatology . . . . . . . . . . . . . . . 4-10

4.7 Geohydrologic Data for the Pinellas Plant . . . . . . . . . . . . . 4-11

4.8 Exposure Data for the Pinellas Plant $\ldots \ldots \ldots \ldots \ldots$. . . . . . . . . .

4.9 Pinellas Plant Population Distribution for Atmospheric Pathway . . . . . . . 4-14

4.10 Distribution of Agriculture Products Around the Pinellas Plant . . . . . . 4-15

4.11 Hanford Reservation Average Local Climatology . . . . . . . . . . . . 4-17

4.12 Geohydrologic Data for the Hanford Reservation . . . . . . . . . . . . 4-19

4.13 Exposure Data for the Hanford Reservation $\ldots \ldots$. . . . . . . . . . 4-20

4.14 Hanford Reservation Population Distribution for Atmospheric Pathway $\ldots \ldots \ldots \ldots \ldots \ldots \ldots$ 4. . . . . . . . . . . .

4.15 Distribution of Agriculture Products Around the Reservation . . . . . . . 4-22

4.16 LANL Average Local Climatology . . . . . . . . . . . . . . . . . . . 4-24

4.17 Geohydrologic Data for the LANL . . . . . . . . . . . . . . 4-26

4.18 Exposure Data for the LANL . . . . . . . . . . . . . . . 4-27 
4.19 LANL Population Distribution for Atmospheric Pathway . . . . . . . . .

4.20 Distribution of Agriculture Products Around the LANL . . . . . . . . . .

4.21 Maywood Average Local Climatology $\ldots \ldots \ldots \ldots \ldots \ldots$. . . . . . . . . .

4.22 Geohydrologic Data for Maywood . . . . . . . . . . . . . . 4-33

4.23 Sandia National Laboratory Average Local Climatology _ . . . . . . . . 4-39

4.24 Geohydrologic Data for the Sandia National Laboratory . . . . . . . . . . 4-39

4.25 Exposure Data for the Sandia National Laboratory . . . . . . . . . . . . 4-40

4.26 Sandia National Laboratory Population Distribution for Atmospheric Pathway $\ldots \ldots \ldots \ldots \ldots \ldots \ldots \ldots \ldots \ldots \ldots \ldots \ldots \ldots$

4.27 Distribution of Agriculture Products Around the Sandia National Laboratory $\ldots \ldots \ldots \ldots \ldots \ldots \ldots$

A.1 Physical Characteristics of Contaminated Soil $\ldots \ldots \ldots \ldots$ A-3

A.2 Constituent Concentrations and Inventories Present in the Contaminated Soil $\ldots \ldots \ldots \ldots \ldots \ldots \ldots$

A.3 Concentration Profile of Radionuclides in the Soil Column . . . . . . . A-10

A.4 Concentration Profile of Organics in the Soil Column ........... 
A.5 Ashland 1 Average Local Climatology . . . . . . . . . . . A-14

A.6 Geohydrologic Data for Tonawanda $\ldots \ldots \ldots \ldots \ldots \ldots \ldots$ A-16 


\section{ACRONYMS}

AMU

ARAR

CEARP

CERCLA

D\&D

DOE

EM

EPA

FEMP

FUSRAP

HLW

HVAC

LANL
Aqueous makeup facility

Applicable, Relevant, and Appropriate Requirements

Comprehensive Environmental Assessment and Response Program

Comprehensive Environmental Response, Compensation, and Liability Act

Decontamination and decommissioning

U.S. Department of Energy

Office of Environment and Waste Management

Environmental Protection Agency

Fernald Environmental Management Project

Formerly Utilized Sites Remedial Action Program

High-level (radioactive) waste

Heating, ventilation, and air conditioning

Los Alamos National Laboratory 
NEPA

National Environmental Policy Act

NPL

National Priority List

NRF

Naval Reactor Facility

ORNL

Oak Ridge National Laboratory

PCBs

Polychlorinated biphenyls

PEIS

Programmatic Environmental Impact Statement

PNL

Pacific Northwest Laboratory

PVC

Polyvinyl chloride

RCRA

Resource Conservation and Recovery Act

RI/FS

Remedial Investigation/Feasibility Study

SNL

Sandia National Laboratory 
SWP

$\mathbf{t}$

TRU

UMTRA

UNH

VSR
Special work permit

metric ton

Transuranic

Uranium Mill Tailings Remedial Action

Uranyl nitrate

Vertical safety rod 


\section{CHAPTER 1: INTRODUCTION}

The U.S. Department of Energy (DOE) has dozens of installations located throughout the U.S. that have historically been, and continue to be, used to carry out various national missions, including providing for nuclear weapons research, development, and production; conducting research to develop new and/or improve existing energy technologies; maintaining a supply of oil reserves for national emergencies; and developing repositories for the disposal of high-level radioactive wastes (HLW) and spent nuclear fuels generated by both DOE and commercial facilities. In addition, the DOE has missions to remediate sites and facilities contaminated as a result of DOE activities, develop remedial and decontamination and decommissioning (D\&D) technologies needed to remediate DOE facilities, and manage the hazardous and radioactive wastes generated from all DOE activities. These latter three missions are the responsibility of the DOE Office of Environmental Restoration and Waste Management (EM), which has initiated a program with the established goal of cleaning up the current inventory of inactive sites and surplus facilities by the year 2019.

Currently, this program, for the most part, does not integrate environmental restoration and waste management activities conducted at each of the individual DOE installations but rather allows each of the installations to operate autonomously. The DOE believes that the efficiency and effectiveness of the program could be improved by implementing a consistent national approach to environmental restoration and waste management activities. For this reason, the DOE has initiated efforts to prepare a Programmatic Environmental Impact Statement (PEIS) that will analyze the existing EM program and evaluate alternatives for an integrated EM program. 


\subsection{Description Of The Peis alternatives}

Five alternative policies for DOE environmental restoration are considered in the PEIS. The first of these alternatives, the "No Action" alternative, is required by the National Environmental Policy Act (NEPA) and is analyzed as a baseline, not because DOE considers it to be an acceptable strategy. Although DOE does not intend to drop contaminated sites and facilities from its program without appropriate investigation, characterization, and evaluation, NEPA requires a "No Action" alternative for comparison with other alternatives. It should be noted that, unlike a programmatic policy, site-specific decisions may lead to no remedial action after appropriate investigation, characterization, and evaluation.

These are the remaining four alternatives:

- The ARAR-Driven Alternative. In the ARAR-driven alternative, remedy selection would be driven by the goal of cleaning up the site to achieve environmental standards regardless of current land use or risk.

- The Land Use-Driven Alternative. In the land use-driven alternative, remedy selection would be driven by the goal of achieving specified land uses. Since it is not feasible in the PEIS to consider all possible land uses for all sites/facilities, the following three bounding land uses are considered: 1) totally restricted access (no access to the site/facility), 2) restriction of access to groundwater, and 3) no restrictions to access. 
- The Health Risk-Driven Alternative. In the health risk-driven alternative, remedy selection is driven by the goal of minimizing overall risk. There are two key concepts in the health risk-driven alternative. First, the decision to remediate a site would be made in the context of the ability of the remedial action to reduce risk to the public associated with some use of the local land or resources. Second, the mode and extent of remediation would be determined by balancing achievable risk reduction (reduction of risk to the local public) with risk incurred to remedial workers, risk associated with transportation for remedial construction, risk sustained by the local public and non-involved workers during remedial activities, risk associated with construction-operation-maintenance of waste treatment/storage/disposal facilities, and risk to the local residents around the disposal site.

- Combination Land Use and Health Risk-Driven Alternative. In the land use and health risk-driven alternative, remedy selection is driven by the goal of achieving a desired land use as described in the land use-driven alternative, but the initial remediation design is evaluated (as in the health risk-driven alternative) to determine the effectiveness of the approach in reducing risk. Once these factors are understood, the land plan is examined for opportunities to make modifications that will achieve most of the original land use goals and improve the effectiveness and efficiency of the plan in reducing risk. 


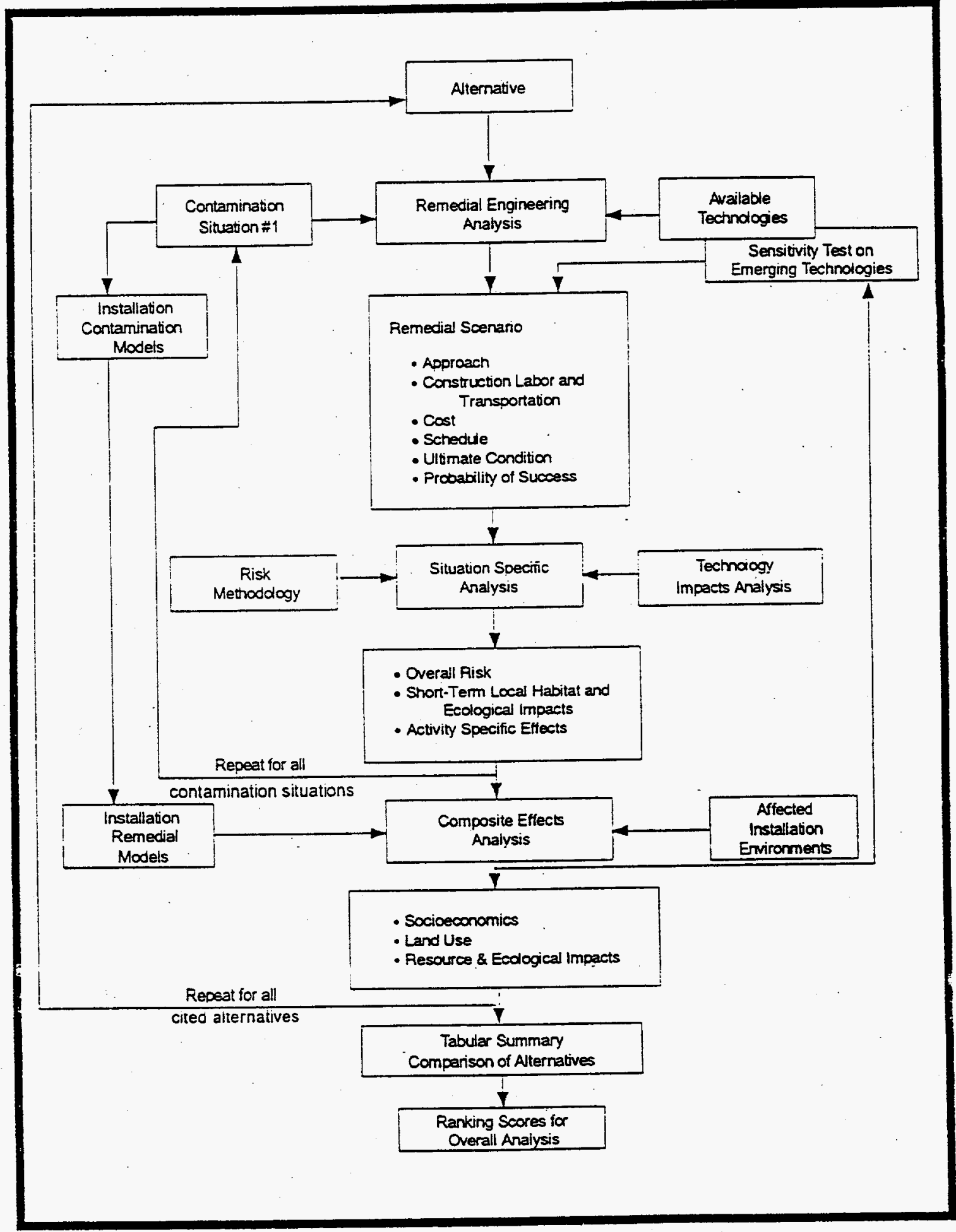

FIGURE 1.1. Approach to Technical Analysis of PEIS Alternatives 
The analytical approach being taken to evaluate each of these alternatives is shown in Figure 1.1. The initial steps in this process are to 1) identify and describe environmental releases and contaminated facilities (e.g., source terms) that exist within the DOE complex, 2) identify appropriate remedial technologies and define the parameters of each needed to do a remedial engineering analysis, 3) develop health and ecological risk methodologies that will allow a risk assessment of each alternative, and 4) analyze the generic impacts of each remedial technology on the environment. The results of each of these tasks are then used to evaluate the health and ecological effects and the socioeconomic impacts of each alternative as applied to all environmental releases and contaminated facilities within the DOE complex.

One of PNL's primary responsibilities within this analytical approach is to identify and describe environmental releases and contaminated facilities that exist within the DOE complex. The DOE complex, for the purposes of the PEIS, includes those DOE installations that were/are part of the Nuclear Weapons Complex and/or have radiologically contaminated sites or facilities. A list of specific DOE installations is provided in Table 1.1. Specifically excluded from the PEIS are these:

- Uranium Mill Tailings Remedial Action (UMTRA) Projects

- Naval Reactor Facility (NRF) located on the Idaho Reservation

- Atomic power laboratories and other DOE facilities supporting naval defense programs 
TABLE 1.1. DOE Installations Included in Analysis

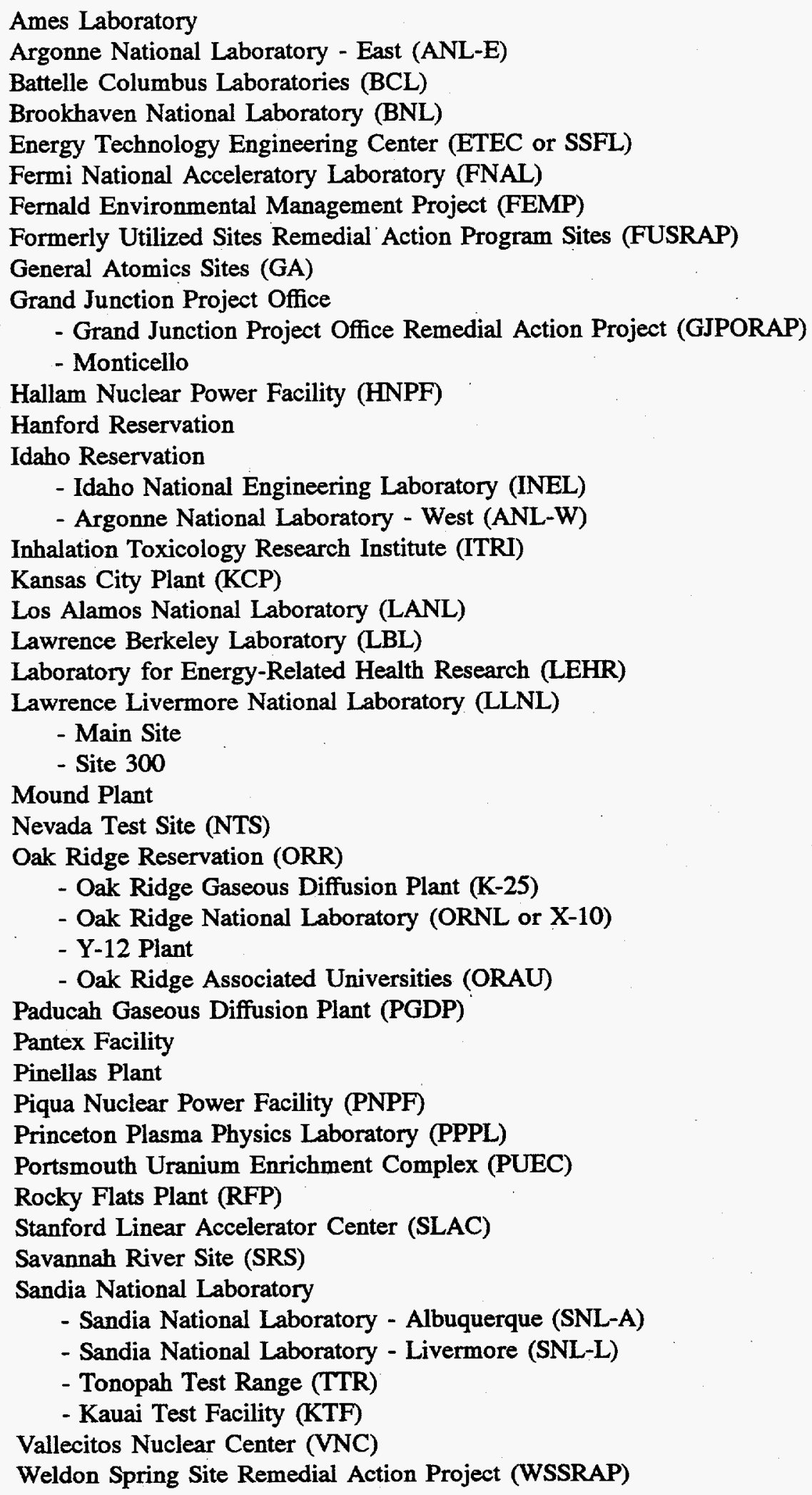


- Naval petroleum, oil, and shale reserves, and strategic petroleum reserves

- Nonradiologically contaminated DOE installations that were never part of the DOE Nuclear Weapons Complex.

\subsection{SOURCE Term Description TASK}

A complete and thorough technical analysis of the programmatic alternatives for each of the more than 10,000 contaminated sites and facilities that have been identified throughout the DOE complex is an unrealistic task within the budget and schedule constraints of the PEIS. However, the analytical approach being taken within the PEIS does allow for a scoping analysis to be done on each contaminated site and facility, assuming that sufficient data exists. The primary responsibility of the source term description task is to identify and scan documents describing contaminated sites and facilities, to extract pertinent data, and enter them into an electronic database. The electronic database has been designed and structured to allow data being extracted from various types of reports and that may have been written for any of a number of different purposes to be organized into a consistent format for easier analysis. Consequently, the analytical models being developed for the PEIS will be able to perform scoping analyses on all contaminated sites and facilities that have sufficient data to drive the models.

While populating the database with data on contaminated sites and facilities is the primary objective of the source term description task, the specific purpose of this report is to describe eleven typical environmental restoration problems that DOE faces. These example situations are being used in the PEIS to 
demonstrate how the remedial engineering analysis and health and ecological effects analyses are being conducted on the thousands of contaminated sites and facilities for each of the alternatives described previously. 


\section{CHAPTER 2: APPROACH}

The process of compiling data on contaminated sites and facilities within the DOE complex began using data that PNL had already compiled for the DOE during a project that began in 1990, preceding initiation of work on the PEIS. While the scope and budget of this earlier project were much smaller than that for the PEIS work, the data were anticipated to be used in total systems analyses very similar to those being done for the PEIS. However, these data were determined to be insufficient for the analyses being done within the PEIS. Consequently, a major effort was initiated during FY1992 to improve and significantly expand upon the data that had been gathered during this earlier effort.

The process of collecting data under this expanded effort has been a multistep process. The first step focused on reviewing data originally gathered as part of the Environmental Survey study that was completed in 1989. Many of the data compiled for this study were, in turn, obtained from individual installation assessment reports generated under the Comprehensive Environmental Assessment and Response Program (CEARP), the predecessor to DOEs current Environmental Restoration Program.

The second step in the process was to obtain more up-to-date data by acquiring more recent reports directly from the individual DOE installations. This step was implemented through the DOE PEIS liaison located at each DOE field or operations office, through whom additional information was passed to PNL. To limit the quantity of material being requested, PNL generally focused on the following types of documents: 
- Remedial investigation/feasibility studies (RI/FS)

- $\quad \mathrm{RI} / \mathrm{FS}$ workplans

- RCRA closure plans

- Records of Decision

- Environmental surveillance reports

- Groundwater monitoring reports

- Federal Facility Agreements

- $\quad$ Site characterization reports

- Decommissioning and decontamination (D\&D) plans.

The third step in the process was to send the extracted data back to the DOE PEIS liaisons for review and concurrence. Since the PEIS analyses focused on contaminated sites and facilities located on the Hanford Reservation, Idaho National Engineering Laboratory, Fernald Environmental Management Project, Oak Ridge Reservation, Rocky Flats Plant, and Portsmouth Uranium Enrichment Complex, Pacific Northwest Laboratory staff also made site visits to each of these installations to review with the appropriate site characterization managers the compiled data. Comments received on the data were, in turn, incorporated into the database. 
The final step in the process is to continue to update the data in the database as new data became available. This final step will continue until completion of the final PEIS.

This entire process of data collection, extraction into an electronic database, and DOE review was followed for both data that were specific to characteristics of the source term and data that were specific to the environmental setting within which each source term existed.

\subsection{Source Term Characteristics Data}

The source term characteristics data included any data that described the physical and/or contaminant characteristics of both sites where known or suspected environmental releases have occurred and sites where there is a potential for environmental releases. Given the wide variation in the production and/or research missions of the numerous DOE facilities, there is a significant diversity in the types of environmental releases and contaminated structures that exist among DOE installations. To compile the data on this wide diversity of sites into a consistent format for use in the PEIS analyses, sites have been grouped into six classes:

- contaminated facilities

- contaminated soils

- $\quad$ solid waste sites (e.g., burial grounds)

- liquid containment structures (e.g., tanks) 
- $\quad$ surface water sites

- groundwater sites.

The data being collected on each of these classes of sites can be grouped into three different categories: site identification data, physical characteristics data, and contaminant data.

The purpose of site identification data is to 1) allow relatively easy correlation of sites included in the PEIS database to sites identified at each individual installation and 2) to provide an overview of the historical use and current status of each site. This includes information such as:

- the name of the site

- the DOE-assigned I.D. for the site

- the DOE Work Breakdown Structure (W.B.S.) number used to fund characterization and remedial action activities on the site

- the operable unit designator (for Comprehensive Environmental Response, Compensation, and Liability Act [CERCLA] sites)

- the current status (active/inactive) of the site

- the cleanup status of the site

- the area on the installation within which the site is located 
- the years of operation of the site

- an overview description of the site and its historical uses.

The physical description data, for the most part, apply to sites that have some sort of structure associated with them. The types of data being collected include physical dimension/size, depth of overburden on top of the structure, the depth to groundwater from the site surface, a description of the construction material used in the structure, and a description of the types of wastes disposed on the site. The database also allows an overview description of the physical characteristics of the site to be entered.

Finally, the contaminant data include descriptions of the types, quantities, and concentrations of each contaminant known or suspected to have been disposed of or released on the site. For soil, groundwater, and surface water classes of sites, data are also collected on the extent of contamination and how deep the contamination is known or suspected to have spread. Contaminant data for liquid containment structures and surface water sites also allow for specifying the form of the contaminated material (e.g., sludge, liquid, sediment). Once again, the database allows an overview description of the contamination associated with the site to be entered.

\subsection{Environmental Setting Data}

Information on environmental settings is classified into three categories: geology/hydrology, climatology, and atmospheric dispersion. The geology/ hydrology data that are compiled on each partially saturated and saturated zone identified for a given area within a DOE installation include the following parameters: 
- thickness of the zone

- $\quad$ soil classification

- sand, silt, and clay composition of the soil

- carbon and iron content in the soil

- soil pH

- $\quad$ soil bulk density

- total porosity of the soil

- $\quad$ soil field capacity

- $\quad$ saturated hydraulic conductivity

- $\quad$ soil capacity

- longitudinal dispersivity.

The climatology data include monthly averages for temperature, amount of precipitation, number of days having precipitation, wind speed, cloud cover, and minimum and maximum daily relative humidity.

Atmospheric dispersion data comprise several tables containing the number of hours within a year that the wind is blowing from any of 16 different directions 
and at eight different wind speeds. Each table containing this data represents a different wind stability class or measure of wind turbulence. The maximum number of wind stability classes is seven.

\subsection{Representative Contaminated Sites ANd Fachities}

This report provides source term characteristics and environmental setting data for eleven situations that broadly represent the types of contaminated sites and facilities that exist throughout the DOE complex. At least one situation has been provided for each class of sites described in Section 2.1. Chapter 3 provides the descriptions for ten of the eleven example sites while Chapter 4 provides six example environmental settings. There are fewer environmental settings than contaminated sites and buildings because an environmental setting may apply to more than one example site.

Because the 11th example site and its associated environmental setting may not be used as additional examples in the PEIS, they are included in an appendix at the end of the report. 


\section{CHAPTER 3: DESCRIPTIONS OF 10 EXAMPLE CONTAMINATED SITES AND BUILDINGS}

This chapter provides descriptions of ten of the eleven example contaminated sites and buildings. These examples are representative of the types of contaminated situations that exist within the DOE complex of installations. The first contamination situation provided is a plot of soil contaminated with the radionuclide cesium- 137 .

A man-made pond contaminated with several organic and inorganic compounds is the second contamination description. The third situation provided is an aquifer contaminated with both radioactive and nonradioactive contaminants.

Two buried waste sites are provided as the fourth and fifth contamination situations. The first is a shaft augured into the ground and used for the disposal of drummed liquid organic wastes. The second situation describes a burial pit for radioactive tailings and slurries.

The sixth, seventh, and eighth contamination situations represent different types of contaminated buildings. The first of these is a small office/storage building whose exterior walls are covered with asbestos shakes. The second building is a chemical separations plant used to separate plutonium from irradiated spent fuel. The final example building is a large nuclear reactor used to produce plutonium for the nuclear weapons program.

Finally, the last two contamination situations represent two different types of contaminated liquid containment structures. The first of these is a concrete holding pond used for temporary storage of low-level liquid radioactive waste. 
The tenth contamination description is for an underground storage tank used as a collection tank for concentrated radioactive liquid low-level waste. An eleventh representative contamination description is provided in Appendix A.

\subsection{Cesium-137-Contaminated SoIL Site}

\section{Overview of Release Site}

The representative contaminated soil site is an experimental site similar to one located at the Oak Ridge National Laboratory (ORNL) that was used to determine the behavior of radioactivity in the environment (DOE 1988b and DOE 1992c). Most of the sites where these experiments took place have very low remaining activity levels. The site included in this report, however, has substantial quantities of $\mathrm{Cs}-137$ remaining.

\section{Description of Release Site}

Experiments were conducted on a field in August 1968 using Cs-137 to provide information on fallout conditions. A plot showing the location of the experimental area, designated WAG 13, is shown in Figure 3.1. Eight 10-x$10-\mathrm{m}$ plots were created for the experiment; they were vegetated with fescue. Each treatment plot was initially surrounded by metal sheeting extending 0.46 $\mathrm{m}$ below ground and $0.61 \mathrm{~m}$ above ground. This metal sheeting has rusted through at various places. In August 1968, four of the plots were contaminated with 8.8 curie $(\mathrm{Ci})$ of $\mathrm{Cs}-137$ fused at high temperatures to silica particles $(100 \mu \mathrm{Ci} / \mathrm{g})$. The other four plots were used as noncontaminated controls. The site physical description is shown in Table 3.1. 


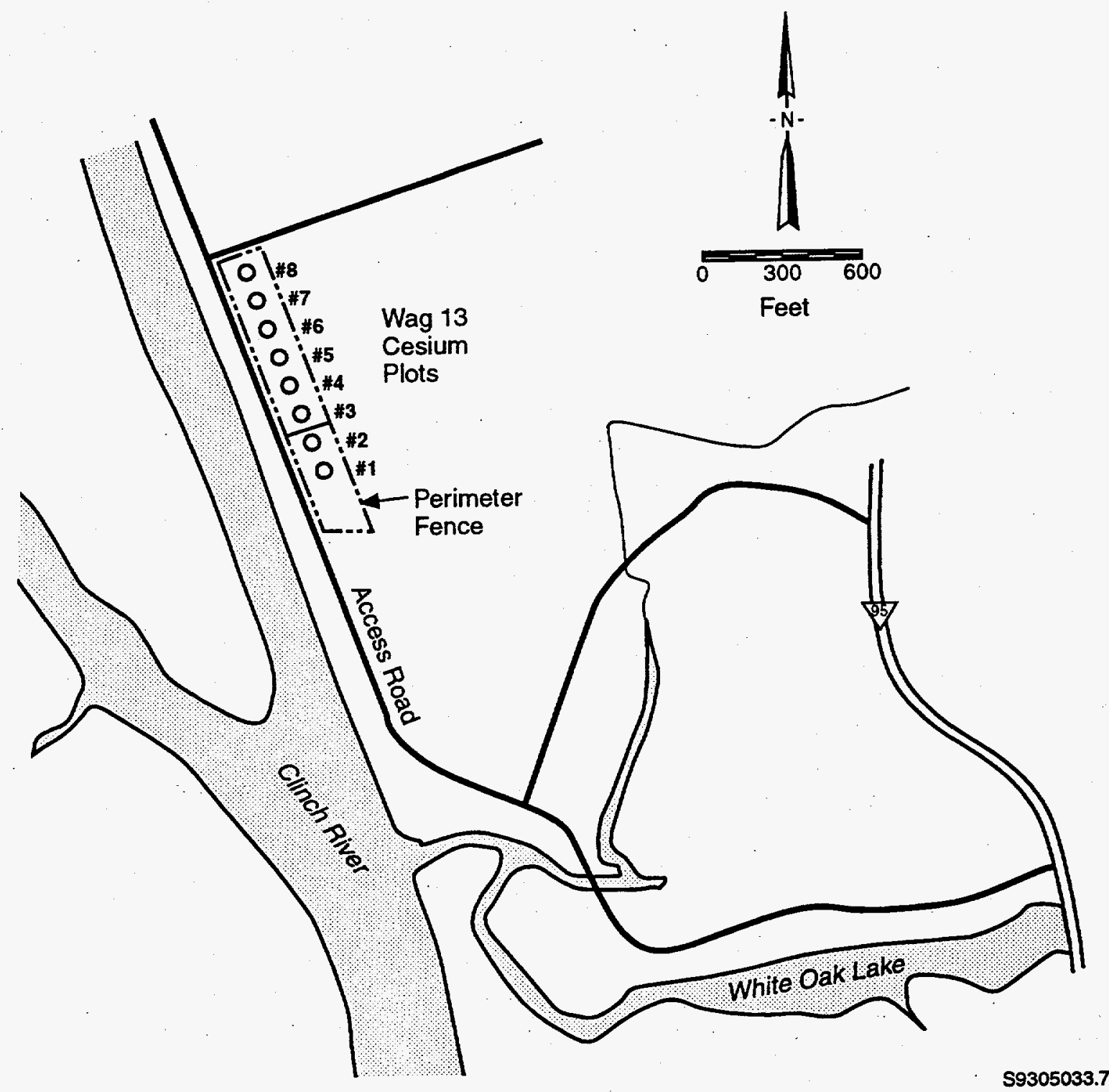

FIGURE 3.1. Location of the Experimental Area 
TABLE 3.1. Physical Description of Cs-137 Contaminated Soil Site

\begin{tabular}{|l|c|c|}
\hline \multicolumn{1}{|c|}{ Dimension } & Values & Units \\
\hline \hline Length & 40 & $\mathrm{~m}$ \\
\hline Width & 10 & $\mathrm{~m}$ \\
\hline Area & 400 & $\mathrm{~m}^{2}$ \\
\hline Overburden & None & \\
\hline Year release initiated & 1968 & \\
\hline Year release terminated & 1968 & \\
\hline
\end{tabular}

\section{Description of Contamination}

A total of $8.8 \mathrm{Ci}$ of $\mathrm{Cs}-137$ was released to the vegetated soil plot. About $5.66 \mathrm{Ci}$ of activity remained in the field in 1987 . Direct radiation levels exceeding $5 \mathrm{mR} / \mathrm{hr}$ were measured at the field by the DOE survey. Table 3.2 lists the waste constituents.

Since data were not available on the extent or depth of contamination in the soil, the distribution of the Cs-137 in the soil was estimated using a onedimensional contaminant transport model that used the environmental parameters for the environmental setting described below and accounted for decay of the radioisotope. The results of this effort are presented in Table 3.3.

\section{Environmental Setting}

The environmental setting for this source term description is provided in Section 4.1. 
TABLE 3.2. Description of Waste Constituents Released at Experimental Site

\begin{tabular}{|l|c|c|c|}
\hline \multirow{2}{*}{ Waste Type } & \multicolumn{2}{|c|}{ Total Quantity } & \multirow{2}{*}{} \\
\cline { 2 - 3 } & Values & Units & Date Released \\
\hline \hline Cs-137 & 8.8 & Ci & August 1968 \\
\hline
\end{tabular}

TABLE 3.3. Vertical Distribution of Cs-137 in the Soil Column for the Experimental Site

\begin{tabular}{||c|c|c|c||}
\hline Depth (cm) & Concentration $(\mathrm{Ci} / \mathrm{g})$ & $\begin{array}{c}\text { Fraction of Total } \\
\text { Inventory } \\
\text { Discharged }(\%)\end{array}$ & Soil Volume $\left(\mathrm{m}^{3}\right)$ \\
\hline \hline Surface & $4.4 \times 10^{-8}$ & $-\cdots$ & $\cdots$ \\
\hline 3.0 & $8.4 \times 10^{-8}$ & 35.2 & 12.2 \\
\hline 6.1 & $5.9 \times 10^{-8}$ & 74.3 & 24.3 \\
\hline 9.1 & $2.0 \times 10^{-8}$ & 93.8 & 36.5 \\
\hline 12.2 & $3.9 \times 10^{-9}$ & 99.0 & 48.6 \\
\hline 15.2 & $4.7 \times 10^{-10}$ & 99.9 & 60.8 \\
\hline 18.2 & $4.0 \times 10^{-11}$ & 100.0 & 73.0 \\
\hline
\end{tabular}

\subsection{Surface Water Site}

\section{Overview of Site}

The representative contaminated surface water site is a man-made pond, similar to a pond located at the Pinellas plant $\left(\mathrm{CH}_{2} \mathrm{M}\right.$ Hill 1987). Past practices at this pond have resulted in contamination of the surface water. Historically, the pond received treated waste water, including neutralized industrial and sanitary waste waters, and storm water runoff. 
Physical Description

Although the pond is man-made, it has been designated a wetlands by the U.S. Department of Interior Fish and Wildlife Service and the National Wetlands Inventory. The elevation of the site is about $5.3 \mathrm{~m}$ above mean sea level (msl); it is not within the 100-year tidal flood elevation of $3.35 \mathrm{~m} \mathrm{msl}$. A schematic of the pond is provided in Figure 3.2. Dimensions and capacity of the pond are provided in Table 3.4 .

\section{Description of Contamination}

Preliminary laboratory analysis of shallow groundwater samples and surface water samples at both the inflow and outflow locations of the pond indicate groundwater contamination with common industrial solvents. Concentrations of dissolved volatile organic constituents, ranging from 0.2 to $60.0 \mu \mathrm{g} / \mathrm{L}$, were detected at some locations. These are listed in Table 3.5.

Reevaluation of surface water quality in the pond was performed as part of a RCRA Facility Investigation. The Environmental Protection Agency (EPA) is currently evaluating this site to determine if a corrective measures study or a "no further actions" report is required.

\section{Environmental Setting}

The environmental setting for this site is provided in Section 4.2.

\subsection{Groundwater Site}

Overview of Site

The typical contaminated groundwater situation is a contaminated unconfined aquifer, similar to a site located beneath the Hanford Reservation (Evans 1992; 


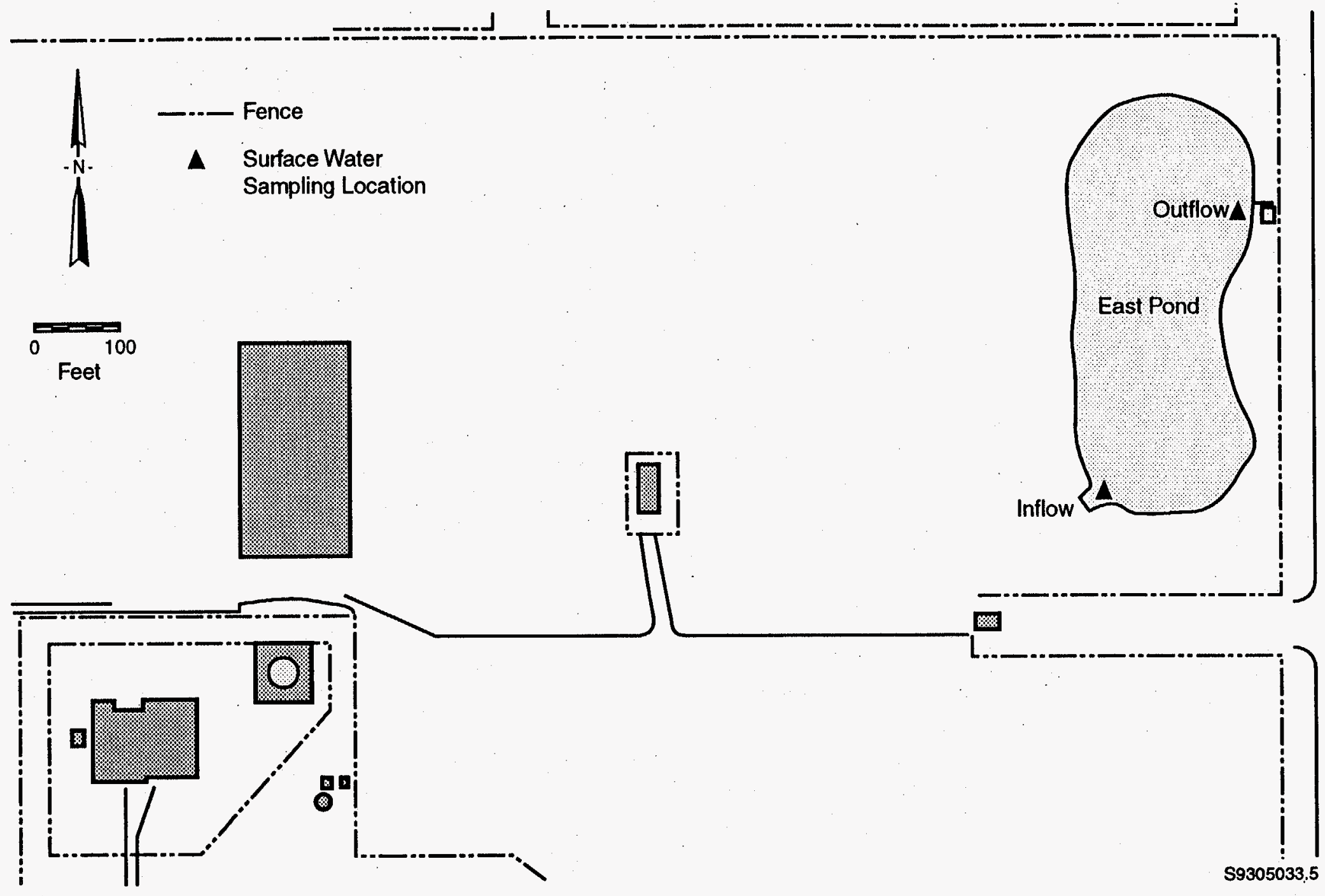

FIGURE 3.2. Pond Schematic 
TABLE 3.4. Description of the Pond

\begin{tabular}{|l|l|c|}
\hline \multicolumn{1}{|c|}{ Dimension } & \multicolumn{1}{c|}{ Values } & Units \\
\hline \hline Length & 152.4 & $\mathrm{~m}$ \\
\hline Width & 67.1 & $\mathrm{~m}$ \\
\hline Average Water Depth & 1.22 & $\mathrm{~m}$ \\
\hline Capacity & $1.23 \times 10^{7}$ & $\mathrm{~L}$ \\
\hline
\end{tabular}

TABLE 3.5. Contaminants Measured in the Pond

\begin{tabular}{||l|c|c|c|c||}
\hline \multirow{2}{*}{$\begin{array}{c}\text { Water Column } \\
\text { Constituent }\end{array}$} & \multicolumn{3}{|c|}{ Concentration } & $\begin{array}{c}\text { Calculated } \\
\text { Remaining } \\
\text { Inventory }\end{array}$ \\
\cline { 2 - 4 } & Min & Max & Average & $123 \mathrm{~g}$ \\
\hline \hline 1,1 Dichloroethylene & 6 & 14 & $10 \mu \mathrm{g} / \mathrm{L}$ & $344 \mathrm{~g}$ \\
\hline Chromium VI & 5 & 50 & $28 \mu \mathrm{g} / \mathrm{L}$ & $738 \mathrm{~g}$ \\
\hline Methylene chloride & 29 & 90 & $60 \mu \mathrm{g} / \mathrm{L}$ & $381 \mathrm{~g}$ \\
\hline Trichloroethylene & 5 & 57 & $31 \mu \mathrm{g} / \mathrm{L}$ & $172 \mathrm{~g}$ \\
\hline Vinyl chloride & 11 & 18 & $14 \mu \mathrm{g} / \mathrm{L}$ & $6,150 \mathrm{~g}$ \\
\hline Cadmium & bmdl ${ }^{(a)}$ & 1 & $0.5 \mathrm{mg} / \mathrm{L}$ & $69,950 \mathrm{~g}$ \\
\hline Lead & bmdl & 13 & $6.5 \mathrm{mg} / \mathrm{L}$ & $79,460 \mathrm{~g}$ \\
\hline Mercury & & & $0.2 \mathrm{mg} / \mathrm{L}$ & 2,46 \\
\hline \hline (a) bmdl = below method detection limit. \\
\hline
\end{tabular}

Newcomer et al. 1991; HEIS 1993). This aquifer underlies a site that has been used extensively for various chemical separations and waste management activities since the mid-1940s. Standard disposal practices for liquid wastes generated from these various activities included discharging the wastes directly into cribs, trenches, ponds, French drains, and reverse wells for percolation 
into the vadose zone. The unconfined aquifer has, as a result, been significantly contaminated from these activities. The area has been placed on the EPA's National Priority List (NPL) for characterization and remediation.

\section{Description of Contamination}

Most of the wells currently used for groundwater surveillance activities are completed in the upper $6.1 \mathrm{~m}$ of the aquifer. Consequently, the vertical extent of contamination in the unconfined aquifer is not well defined. The approximate thickness of the aquifer should be the upper limit of the plume thickness. The lower limit of the plume thickness is the distance between the water table and the bottom of the well screen (sampling thickness).

The average surface elevation of this area is about $213 \mathrm{~m}$. The average water table elevation of this area was $141 \mathrm{~m}$ in June 1990. Thus the average depth to the water table is assumed to be about $72 \mathrm{~m}$ in this area. The thickness of the unconfined aquifer in this area is assumed to be approximately $76 \mathrm{~m}$. The average sampling thickness of the wells in this area is $16.5 \mathrm{~m}$. From these estimates, the contaminant plume thickness in this area could range anywhere from $16.5 \mathrm{~m}$ to $76 \mathrm{~m}$, but it is conservatively assumed to be $76 \mathrm{~m}$ for this situation. The depth to the top of the contaminant plume is the same as the depth to the water table. Finally, a groundwater mound was formed by the extensive discharging of liquid wastes into the vadose zone in this area. The water table elevation has been dropping as much as $0.46 \mathrm{~m} / \mathrm{year}$ the last few years, because much of the liquid waste discharging has stopped.

Constituents detected in the unconfined aquifer are shown in Table 3.6. Groundwater plume maps are also provided in Figures 3.3 through 3.12 for each of the contaminants shown in Table 3.6. The average concentration for 
each plume was calculated using a weighted average for each area within a contour interval. The contaminant inventories provided in Table 3.6 were estimated using the surface area provided (which is the total area contained within the lowest concentration contour) and assuming a 76-m plume thickness and an average porosity of $20 \%$. The total area of the plume confined within the lowest concentration contour is assumed to contain $99.9999 \%$ of the total contaminant inventory. Residual inventory outside of the lowest concentration contour is, therefore, assumed to be $0.0001 \%$ of the total inventory.

TABLE 3.6. Contaminants Measured in the Groundwater

\begin{tabular}{|c|c|c|c|c|c|c|}
\hline \multirow[b]{2}{*}{ Constituent } & \multirow[b]{2}{*}{ Inventory } & \multirow{2}{*}{$\begin{array}{c}\text { Depth to } \\
\text { Plume }\end{array}$} & \multirow{2}{*}{$\begin{array}{c}\text { Surface } \\
\text { Area }\end{array}$} & \multicolumn{3}{|c|}{ Concentration } \\
\hline & & & & Min & $\operatorname{Max}$ & Average \\
\hline Cyanide & 270 kilogram $(\mathrm{kg})$ & $72 \mathrm{~m}$ & $9.48 \times 10^{5} \mathrm{~m}^{2}$ & 15 & 69 & $0.019 \mathrm{mg} / \mathrm{L}$ \\
\hline Fluoride & $53,860 \mathrm{~kg}$ & $72 \mathrm{~m}$ & $1.43 \times 10^{6} \mathrm{~m}^{2}$ & 1.5 & 12.8 & $2.47 \mathrm{mg} / \mathrm{L}$ \\
\hline Chromium $^{(a)}$ & $2,230 \mathrm{~kg}$ & $72 \mathrm{~m}$ & $1.60 \times 10^{6} \mathrm{~m}^{2}$ & 50 & 339 & $0.0914 \mathrm{mg} / \mathrm{L}$ \\
\hline Carbon Tetrachloride & $97,390 \mathrm{~kg}$ & $72 \mathrm{~m}$ & $8.21 \times 10^{6} \cdot \mathrm{m}^{2}$ & 5 & 8,700 & $0.778 \mathrm{mg} / \mathrm{L}$ \\
\hline Chloroform & $2,490 \mathrm{~kg}$ & $72 \mathrm{~m}$ & $1.51 \times 10^{6} \mathrm{~m}^{2}$ & 10 & 1,550 & $0.108 \mathrm{mg} / \mathrm{L}$ \\
\hline 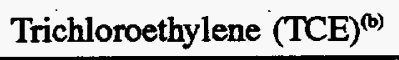 & $230 \mathrm{~kg}$ & $72 \mathrm{~m}$ & $1.18 \times 10^{6} \mathrm{~m}^{2}$ & 10 & 41 & $0.0129 \mathrm{mg} / \mathrm{L}$ \\
\hline Nitrate & $6.328 \mathrm{E} 7 \mathrm{~kg}$ & $72 \mathrm{~m}$ & $2.12 \times 10^{7} \mathrm{~m}^{2}$ & 45 & 1,360 & $196 \mathrm{mg} / \mathrm{L}$ \\
\hline Technetium-99 & $57 \mathrm{~kg}$ & $72 \mathrm{~m}$ & $1.07 \times 10^{7} \mathrm{~m}^{2}$ & 900 & 25,900 & $6,020 \mathrm{pCi} / \mathrm{L}$ \\
\hline Iodine-129 & $7.36 \mathrm{~kg}$ & $72 \mathrm{~m}$ & $1.29 \times 10^{7} \mathrm{~m}^{2}$ & 1 & 33.4 & $6.17 \mathrm{pCi} / \mathrm{L}$ \\
\hline Uranium $^{(\mathrm{c})}$ & $79,160 \mathrm{~kg}$ & $72 \mathrm{~m}$ & $3.21 \times 10^{6} \mathrm{~m}^{2}$ & 35 & 2,000 & $546 \mathrm{pCi} / \mathrm{L}$ \\
\hline
\end{tabular}




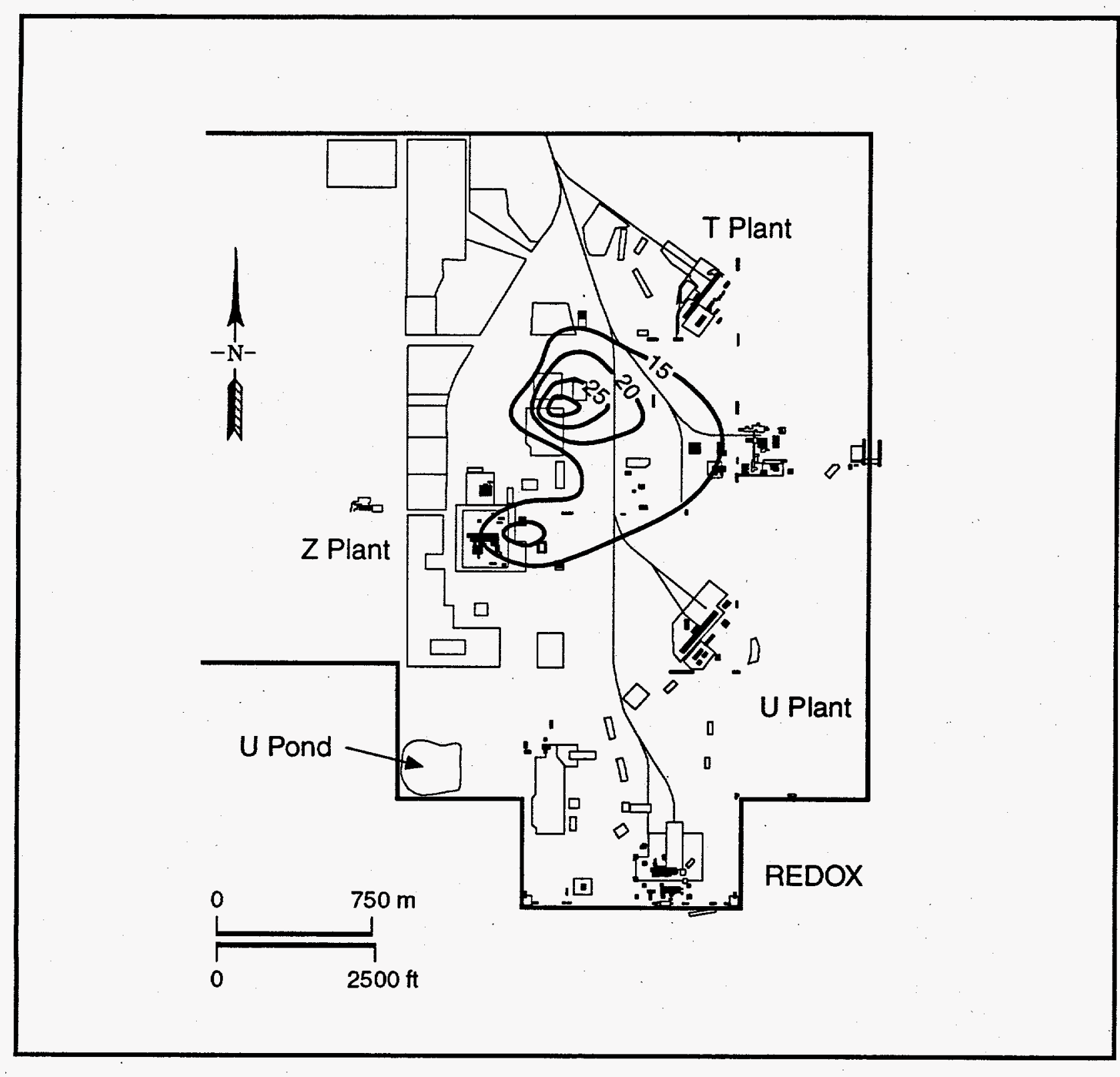

$\$ 9305033.17$

FIGURE 3.3. Groundwater Contours for the Cyanide Plume ( $\mu \mathrm{g} / \mathrm{L})$ 


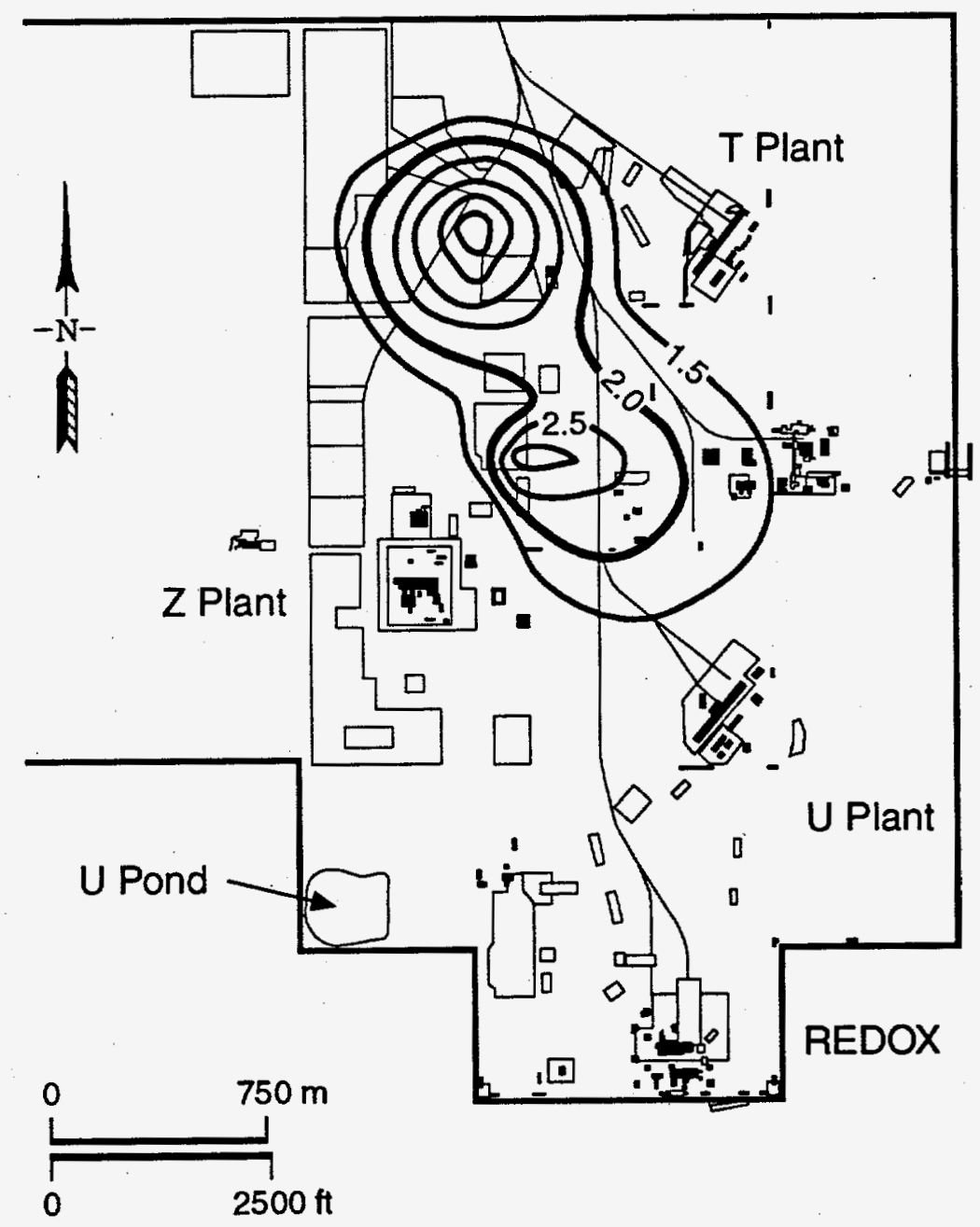

$\$ 9305033.16$

FIGURE 3.4. Groundwater Contours for the Fluoride Plume (mg/L) 


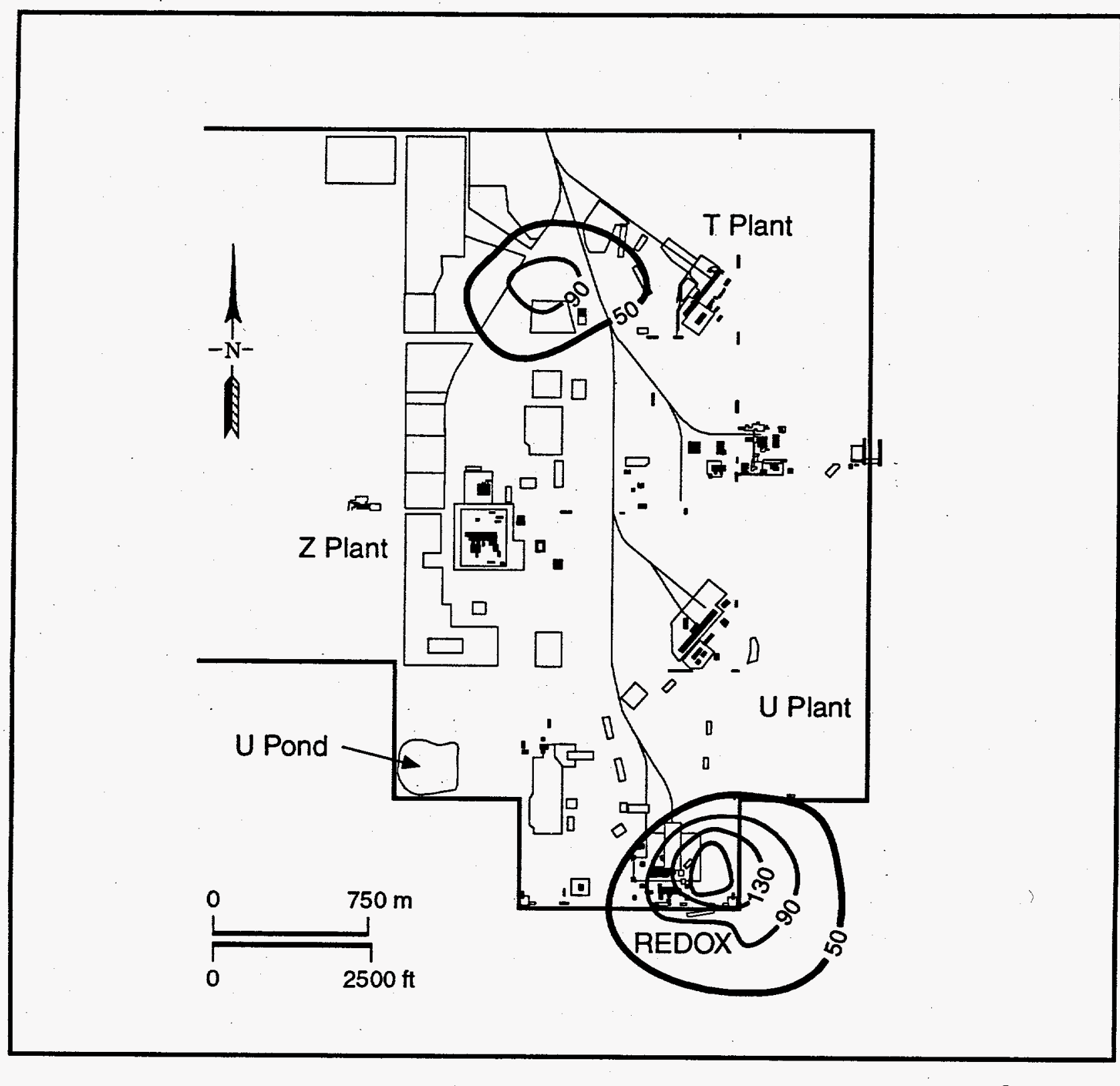

\$9305033.15

FIGURE 3.5. Groundwater Contours for the Chromium Plume $(\mu \mathrm{g} / \mathrm{L})$ 


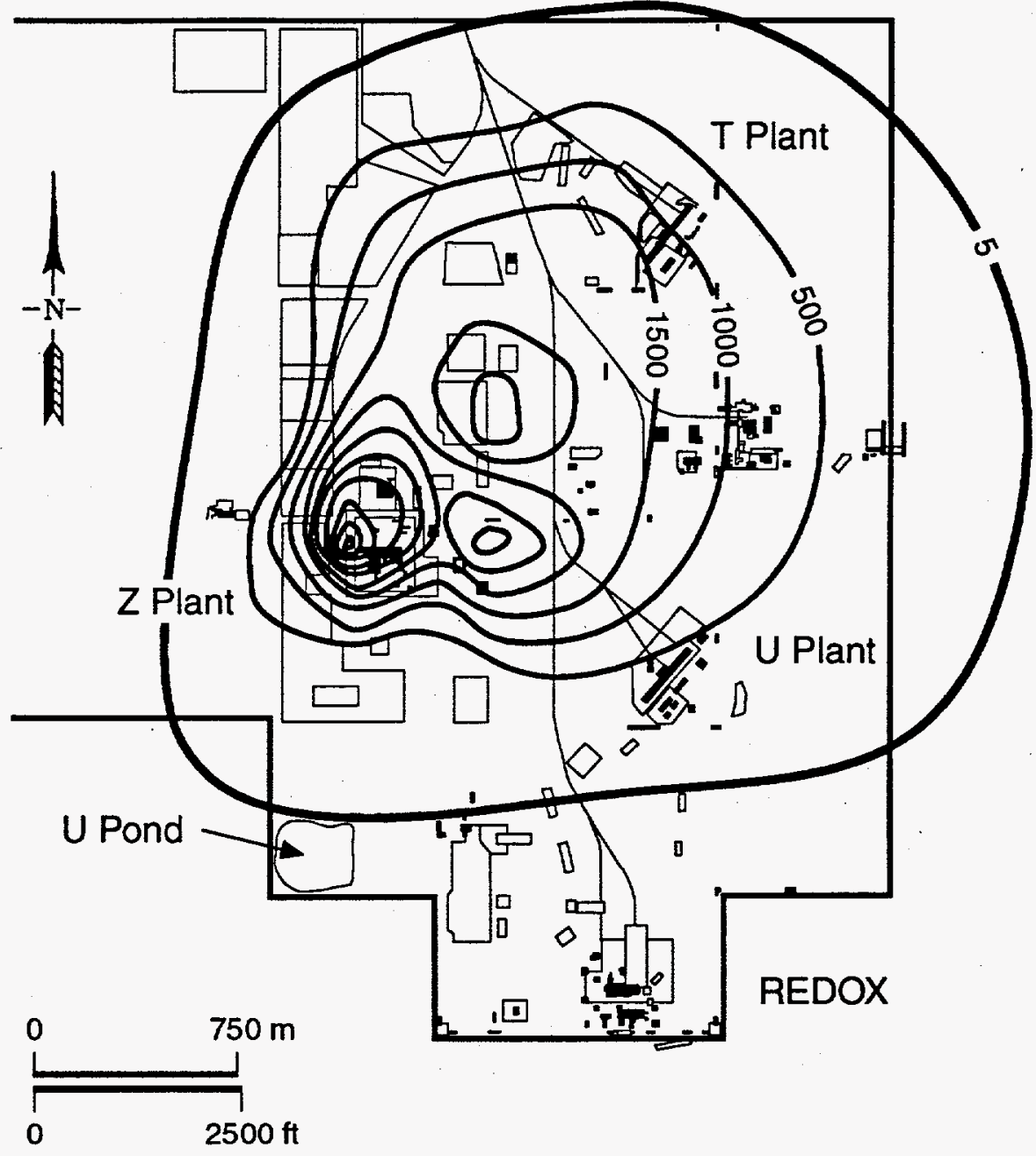

59305033.14

FIGURE 3.6. Groundwater Contours for the Carbon Tetrachloride Plume $(\mu \mathrm{g} / \mathrm{L})$ 


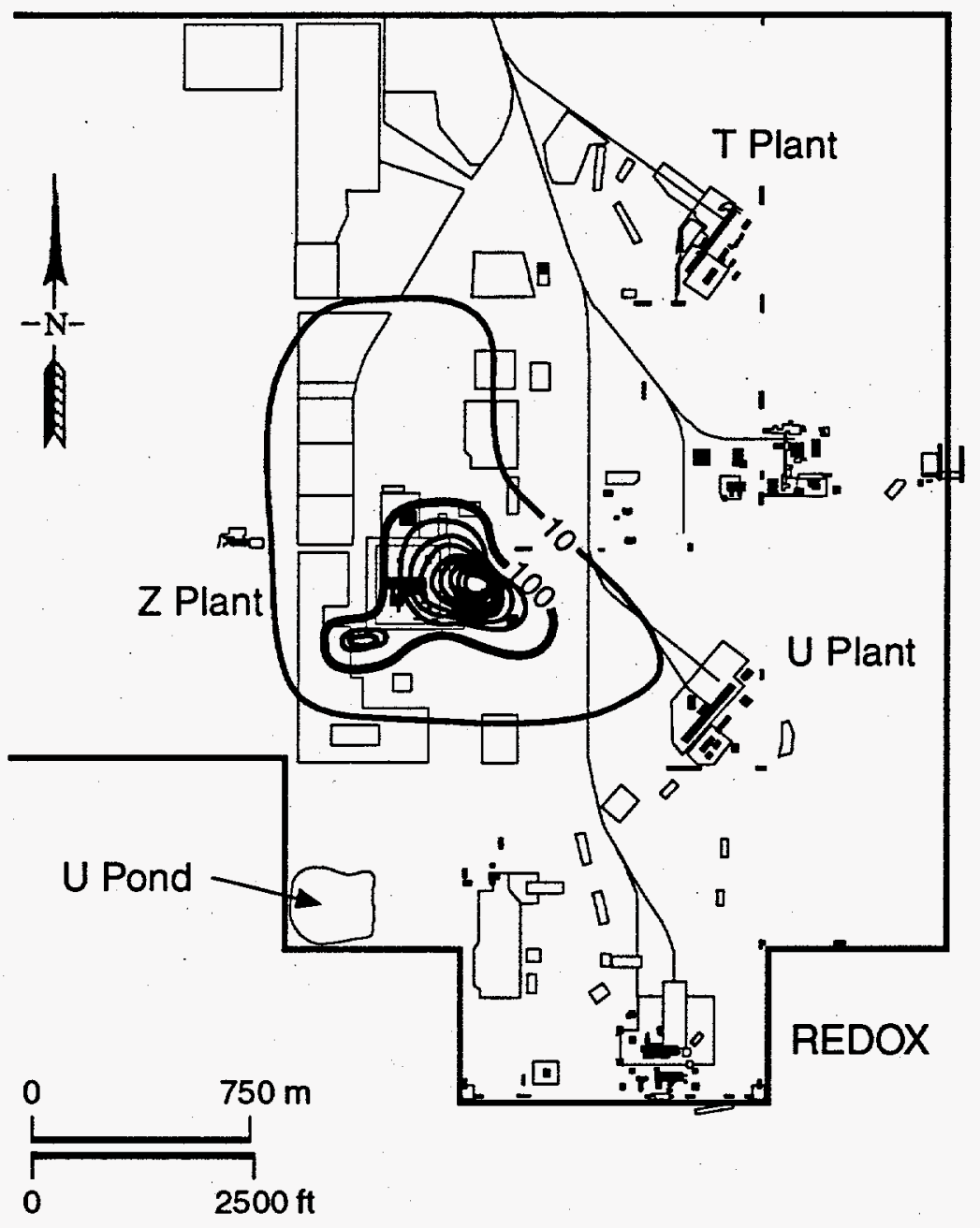

S9305033.13

FIGURE 3.7. Groundwater Contours for the Chloroform Plume $(\mu \mathrm{g} / \mathrm{L})$ 


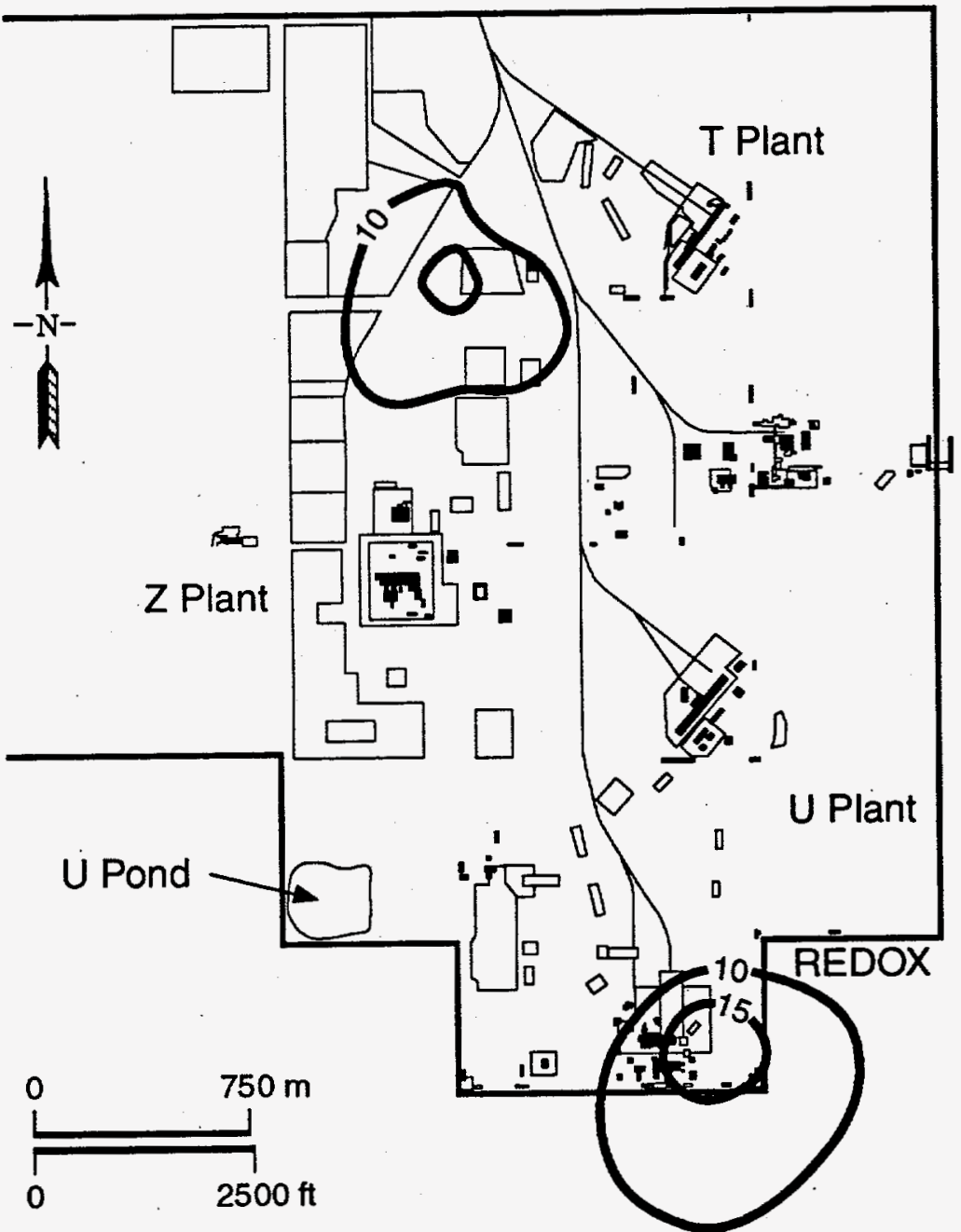

$\$ 9305033.12$

FIGURE 3.8. Groundwater Contours for the Trichloroethylene Plume ( $\mu \mathrm{g} / \mathrm{L})$ 


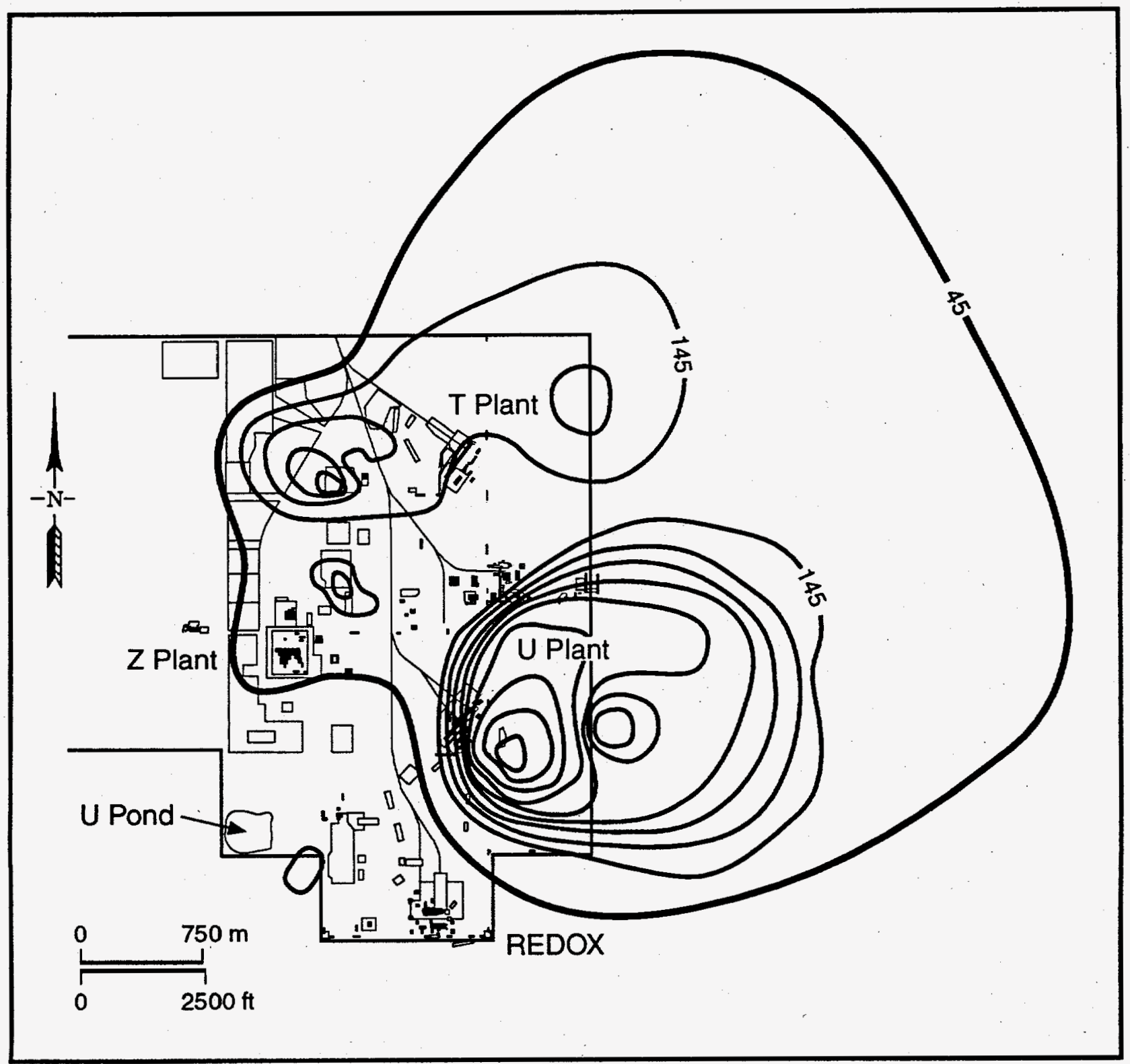

59305033.11

FIGURE 3.9. Groundwater Contours for the Nitrate Plume (mg/L) 


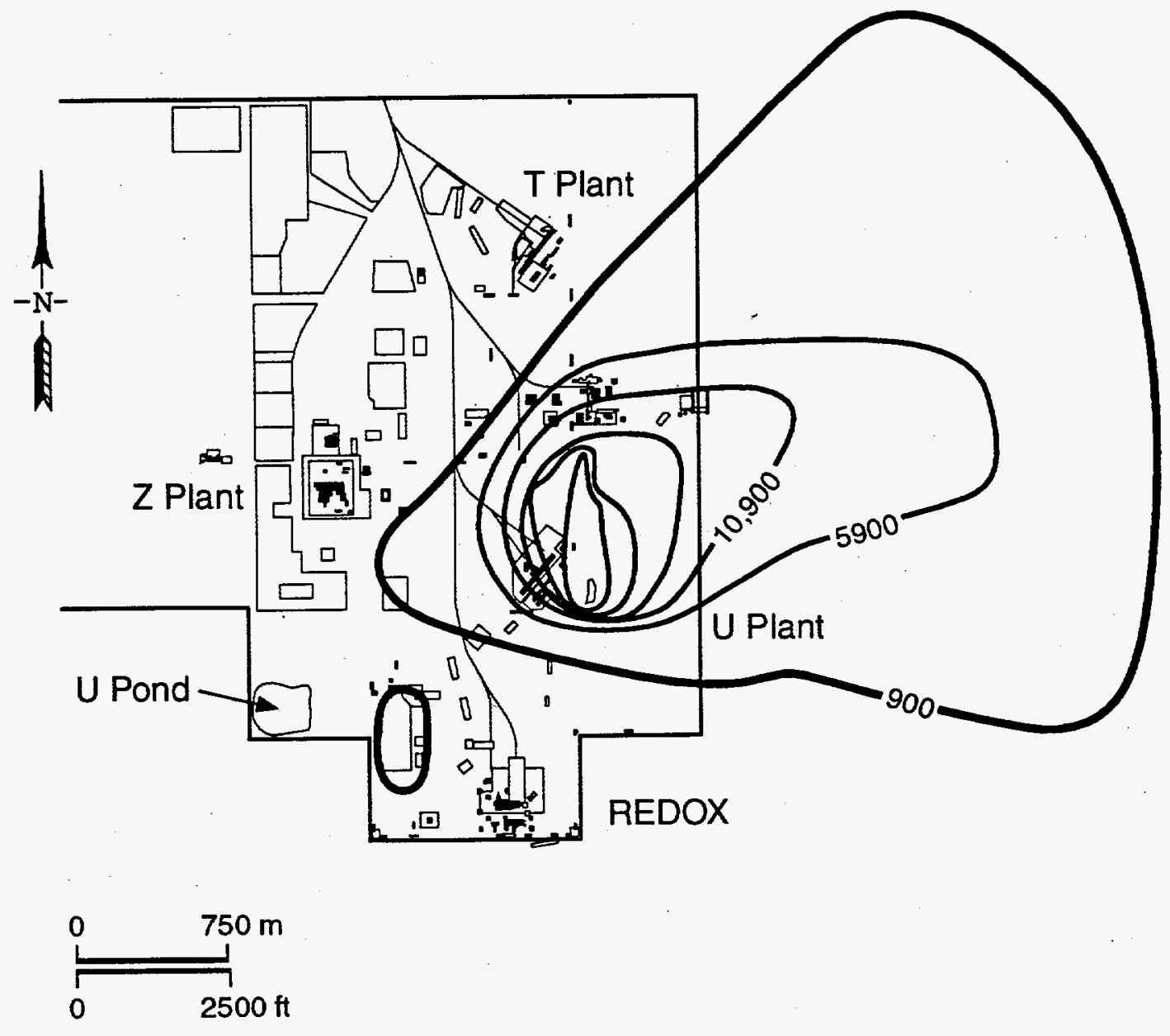

59305033.20

FIGURE 3.10. Groundwater Contours for the Technetium-99 Plume (pCi/L) 


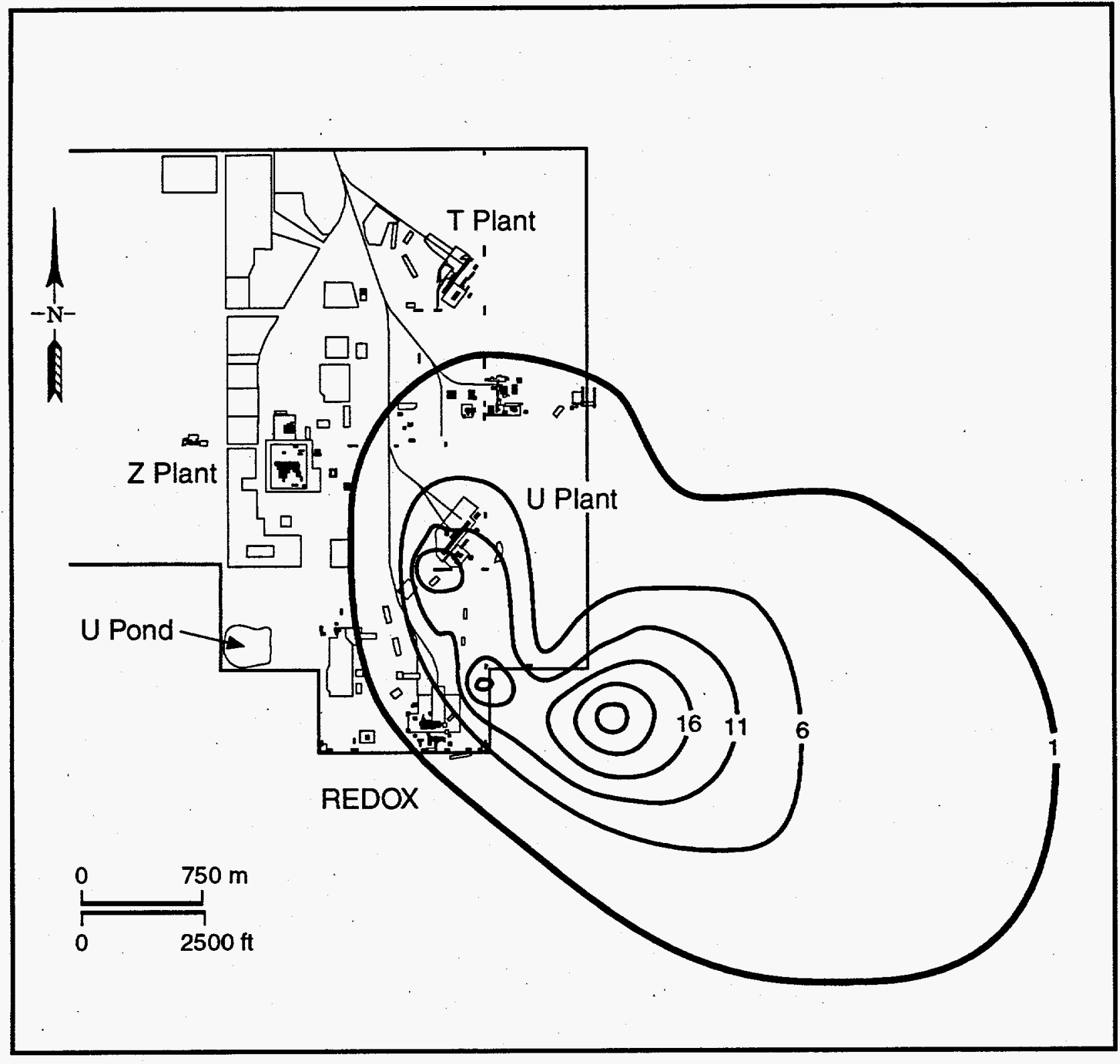

S9305033.19

FIGURE 3.11. Groundwater Contours for the Iodine-129 Plume (pCi/L) 


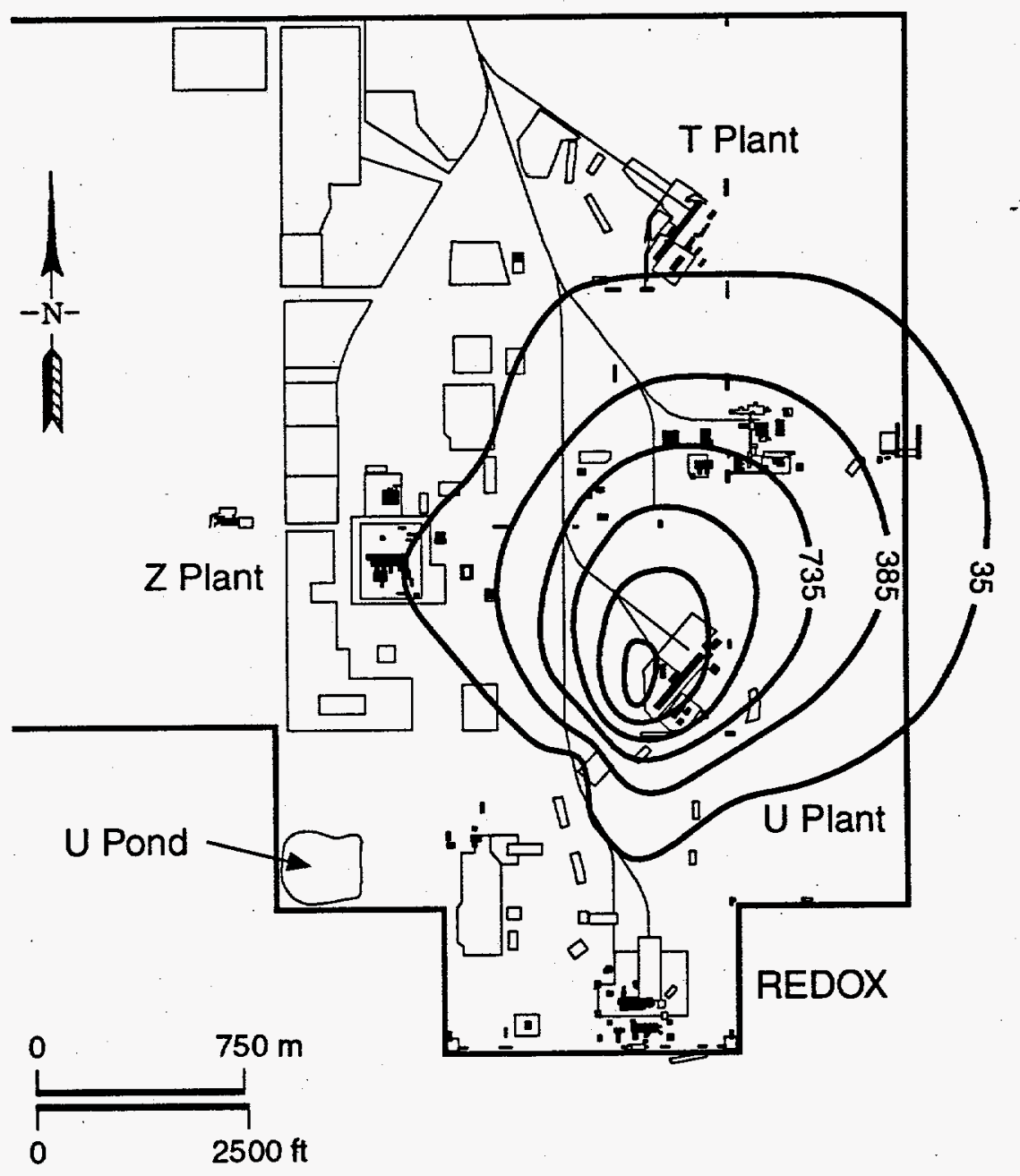

$\$ 9305033.18$

FIGURE 3.12. Groundwater Contours for the Uranium Plume (pCi/L) 
Of the plumes described, only the nitrate plume (Figure 3.9) shows a minimum concentration contour that is greater than the established cleanup criterion. The reason for this is that the outer edges of this plume have merged with other nitrate plumes on the site. For the purposes of this analysis, only the area within the outer concentration contour shown in Figure 3.9 is included as part of the remedial action for this groundwater site. The remainder of the nitrate plume is assumed to be addressed as part of other remedial actions.

\section{Environmental Setting}

The Environmental setting for this contaminated groundwater plume is provided in Section 4.3.

\subsection{Hazardous Waste BuRial Shaft}

\section{Overview of Süte}

The representative burial ground is a $10,440-\mathrm{m}^{2}$ site, similar to a site located at the Los Alamos National Laboratory (LANL) that is presently used for RCRApermitted chemical waste storage and treatment and for mixed waste storage under interim status authority (LANL 1992). This site is located on flat land on top of a mesa, with all surface water runoff directed through a flume to discharge down the mesa wall into the canyon below. The groundwater table is approximately 870 feet below the mesa top.

Before 1985, this site was used for land disposal of hazardous chemicals, which were disposed in a pit (Pit A), three unlined surface impoundments (Impoundments B, C, and D), and 34 drilled shafts (Shafts 1 through 34). Records 
indicate disposal of $690 \mathrm{~m}^{3}$ of organic and inorganic wastes between 1975 and 1985. Figure 3.13 shows the locations of Pit A, the shafts, and the surface impoundments at this burial ground.

\section{Physical Description}

Shaft 17 is indicative of practices and wastes common to the shafts used for permanent disposal of hazardous wastes. The shaft, $0.91 \mathrm{~m}$ in diameter, was dry-drilled into the mesa tuff to a depth of $18.3 \mathrm{~m}$. The bottom was lined with $0.91 \mathrm{~m}$ of crushed tuff and capped with a hinged steel cap until closure, when the steel cap was replaced with a permanent $0.91-\mathrm{m}$-thick concrete plug.

Individual drums of waste were lowered by crane down into the shaft through the hinged door one at a time and stacked on one another in layers of one drum each. The space between the shaft walls and the drums was filled with crushed tuff for protection and to increase vertical bearing strength. An average $0.15 \mathrm{~m}$ of crushed tuff was layered between drums. Adsorbents were not added to the drums of liquid waste; smaller containers and noncontainerized wastes were often simply dropped down the shaft without procedure.

Table 3.7 gives a summary of the physical dimensions of the burial shaft, the years of operation, and an estimate of the quantities of various waste types disposed of in Shaft 17. Radioactive wastes do not appear to have been disposed at the site. A maximum of sixteen 55-gallon drums could have been disposed of in this shaft, accounting for approximately $3.3 \mathrm{~m}^{3}$ of the wastes disposed. The remainder of the waste volume disposal must have been either in smaller containers or uncontainerized, or a combination of both. 


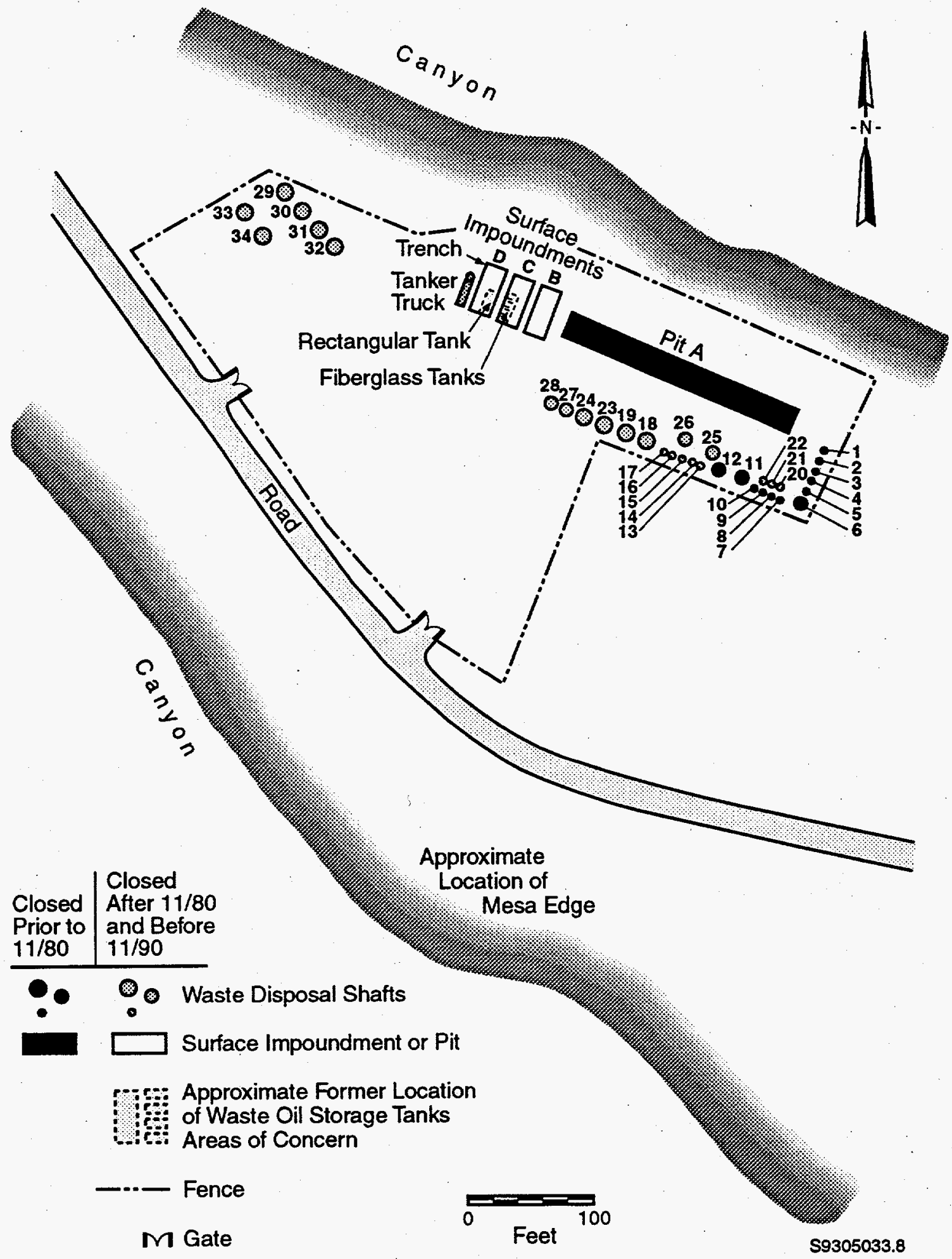

FIGURE 3.13. Inactive Pit, Impoundments, and Shafts at the Burial Grounds 
TABLE 3.7. Summary of Data on Shaft 17

\begin{tabular}{||l|c|c||}
\hline \hline Start operations & \multicolumn{2}{|c|}{ June 1979 } \\
\hline End operations & \multicolumn{2}{|c|}{ April 1982 } \\
\hline Diameter & 0.91 & $\mathrm{~m}$ \\
\hline Depth & 18.3 & $\mathrm{~m}$ \\
\hline Total capacity & 12 & $\mathrm{~m}^{3}$ \\
\hline Total waste volume disposed & 11.1 & $\mathrm{~m}^{3}$ \\
\hline Total organic waste disposed & 9.24 & $\mathrm{~m}^{3}$ \\
\hline Total inorganic waste disposed & 0.61 & $\mathrm{~m}^{3}$ \\
\hline Total unclassifiable waste disposed & 1.27 & $\mathrm{~m}^{3}$ \\
\hline
\end{tabular}

\section{Description of Contamination}

This site was used for the disposal of $11.1 \mathrm{~m}^{3}$ of wastes from 1979 to 1982 . These wastes were classified at the time of disposal according to their organic content; however, detailed records were not kept identifying the specific quantity of hazardous chemicals disposed. The contaminant inventories provided in Table 3.8 were estimated using engineering judgment by assuming that the ratio of contaminant concentrations detected in the vadose zone was the same as that of what was originally disposed of in the shaft.

\section{Environmental Setting}

The environmental setting for this burial ground is provided in Section 4.4. 
TABLE 3.8. Estimated Inventory of Contaminants in Shaft 17

\begin{tabular}{||l|c|c||}
\hline \multicolumn{1}{|c|}{ Contaminant } & Inventory & Units \\
\hline \hline 1,1,1-trichloroethane & 10,940 & $\mathrm{~kg}$ \\
\hline Trichloroethane & 1,604 & $\mathrm{~kg}$ \\
\hline Chloroform & 207 & $\mathrm{~kg}$ \\
\hline Toluene & 70 & $\mathrm{~kg}$ \\
\hline Carbon tetrachloride & 116 & $\mathrm{~kg}$ \\
\hline Tetrachloroethane & 115 & $\mathrm{~kg}$ \\
\hline
\end{tabular}

\subsection{Radioactive Waste Burial Pit}

\section{Overview of Site}

The representative radioactive waste burial pit is similar to a burial pit located at the Maywood Site, ${ }^{(a)}$ whose remediation is being addressed under the Formerly Utilized Sites Remedial Action Program (FUSRAP) (DOE 1992a; DOE 1992b). This pit, referred to as Burial Pit 1, is similar to two other burial pits located on the same site and was used to dispose of radioactive tailings and slurries generated from a thorium extraction process. In this process, thorium was extracted from monazite sand for use in manufacturing industrial products such as mantles for gas lanterns. The manufacturing process involved the production of mantle-grade thorium nitrate.

Unrecoverable wastes from the thorium processing operations (e.g., residues and tailings) were piped to a large pile. The pile, containing several tons of

(a) U.S. Department of Energy (DOE). 1993. "Feasibility Study Environmental Impact Statement for the Maywood Site." Former Sites Restoration Division, Washington, D.C. 
waste slurry, was surrounded by earthen dikes but remained exposed to the weather. Wastes from this pile were subsequently excavated and buried in three different burial pits; disposal in Burial Pit 1 occurred in 1966.

\section{Physical Description}

The location and approximate site of Pit 1 is shown in Figure 3.14. It has dimensions of approximately $60 \mathrm{~m}$ by $30.5 \mathrm{~m}$, thereby occupying more than $1800 \mathrm{~m}^{2}$ of land. The pit was excavated to a depth of about $4.7 \mathrm{~m}$ and was not lined with a synthetic liner. In 1966 , approximately $6,400 \mathrm{~m}^{3}$ of radioactive waste from a tailings pile and a slurry pile was placed into this pit. The waste was subsequently covered to a depth of 0.9 to $1.2 \mathrm{~m}$ with clean fill material. This area is now covered with grass. Table 3.9 summarizes the physical characteristics of this pit.

\section{Description of Contamination}

The primary radioactive contaminant at this site is thorium-232 (Th-232) and its associated daughter products, with lesser amounts of radionuclides in the uranium-238 (U-238) decay chain. These are the primary contaminants of interest, because natural thorium was a direct product of the thorium processing operations at this site and was a component of the original monazite sands used as feed material. Historical information about the thorium processing operations indicates that no organic contaminants were introduced during processing. 


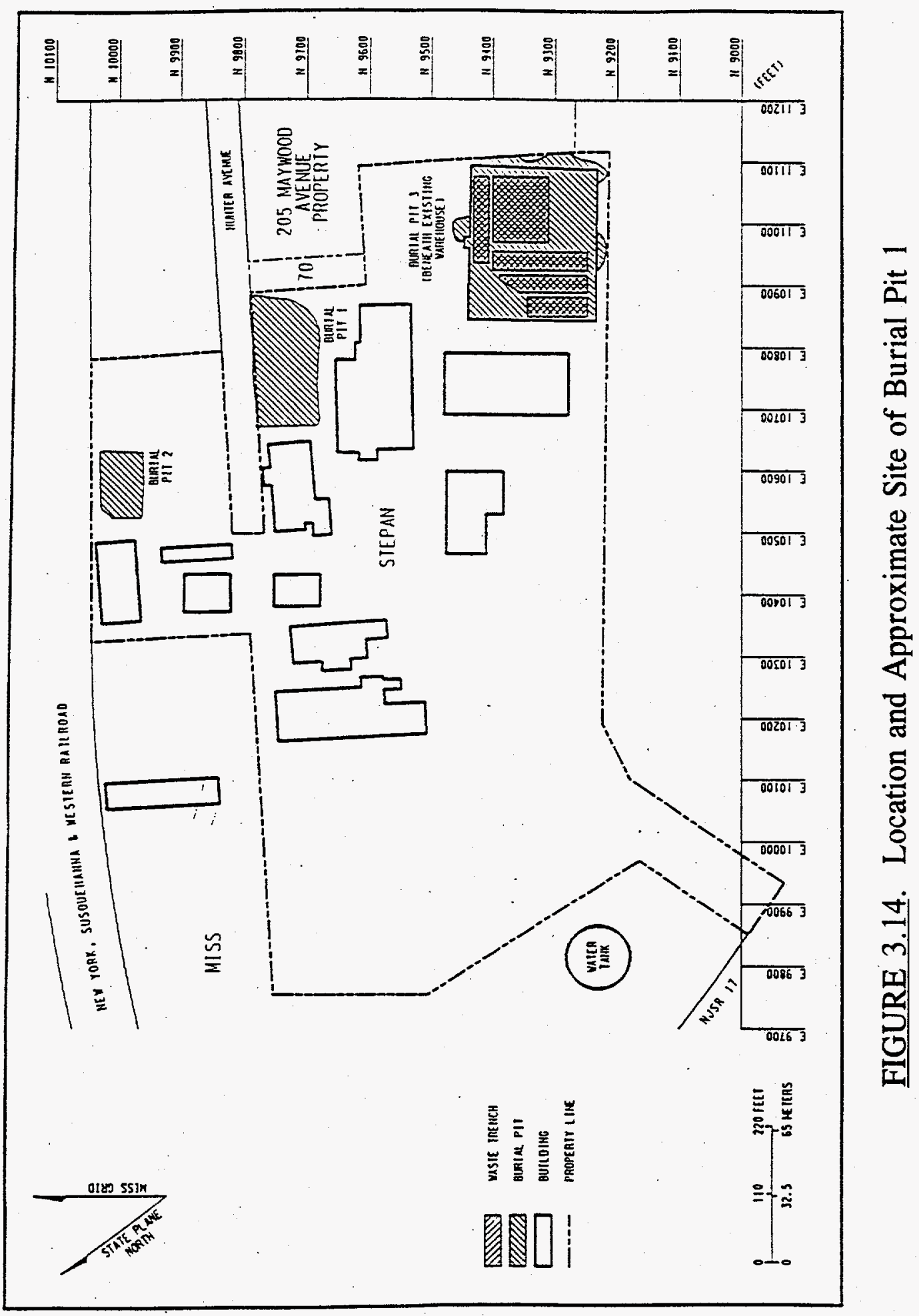


TABLE 3.9. Physical Characteristics of Burial Pit 1

\begin{tabular}{|l|c|c||}
\hline \multicolumn{1}{|c|}{ Dimension } & Values & Units \\
\hline \hline Length & 60 & $\mathrm{~m}$ \\
\hline Width & 30.5 & $\mathrm{~m}$ \\
\hline Depth & 4.7 & $\mathrm{~m}$ \\
\hline Overburden depth & 1.2 & $\mathrm{~m}$ \\
\hline Surface area & 1,830 & $\mathrm{~m}^{2}$ \\
\hline Liner material & None & \\
\hline Volume of waste disposed & 6,400 & $\mathrm{~m}^{3}$ \\
\hline Year of disposal & 1966 & \\
\hline Elevation of site surface & 19.8 & $\mathrm{~m} \mathrm{msl}^{(\mathrm{a})}$ \\
\hline (a) Mean sea level. & & \\
\hline
\end{tabular}

Sampling the material within the burial pit resulted in detecting the presence of three different radioisotopes: Th-232, Ra-226, and U-238. Samples were taken from about 15 different locations around the pit and from a number of depths at each location. The highest concentration of $\mathrm{Th}-232$ detected was $1,592 \mathrm{pCi} / \mathrm{g}$ from a borehole near the northwest corner of the pit. Ra-226 had a high concentration of $333 \mathrm{pCi} / \mathrm{g}$, while the highest concentration for U-238 was $170 \mathrm{pCi} / \mathrm{g}$ along the eastern and southern edges, respectively, of the pit.

Nuclear Regulatory Commission (NRC) records indicate that the waste placed in both Burial Pits 1 and 2 contained a total of 980,640 kilogram (kg) $\left(1,530 \mathrm{~m}^{3}\right)$ of thorium waste material that is $1.5 \%$ thorium phosphate, yielding a total quantity of approximately $8,100 \mathrm{~kg}$ of thorium containing approximately $880 \mathrm{mCi}$ of Th-232. Based on these NRC records, it is estimated that the total inventory of the $\mathrm{Th}-232$ in $\mathrm{Pit} 1$ is $704 \mathrm{mCi}$ within a total waste volume of $6,400 \mathrm{~m}^{3}$. 
Also, since both Ra-226 and U-238 were detected in the samples taken from the waste material within Burial Pit 1, estimates were made of the inventory of each of these radioisotopes based on their average measured concentration. The average $\mathrm{Ra}-226$ concentration was determined to be approximately $52.6 \mathrm{pCi} / \mathrm{g}$, while the average U-238 concentration was determined to be approximately $15.6 \mathrm{pCi} / \mathrm{g}$. Refer to Table 3.10 for a summary of the estimated inventory of each of the radioisotopes present in Burial Pit 1.

\section{Environmental Setting}

The environmental setting for this source term description is provided in Section 4.5.

\subsection{OFFICE/STORAge BUILDING}

\section{Overview of Facility}

A typical nonradioactively contaminated facility is a custodial service building used as an office and storage area for supplies and equipment. This facility is a single-story, wood-frame structure on grade with concrete block foundation and

TABLE 3.10. Estimate of Contaminant Inventories in Burial Pit 1

\begin{tabular}{||c|c|c||}
\hline Contaminant & Inventory & Units \\
\hline \hline Th-232 & 6,480 & $\mathrm{~kg}$ \\
& 704 & $\mathrm{mCi}$ \\
\hline Ra-226 & 0.14 & $\mathrm{~g}$ \\
& 143 & $\mathrm{mCi}$ \\
\hline U-238 & 125 & $\mathrm{~kg}$ \\
& 43 & $\mathrm{mCi}$ \\
\hline
\end{tabular}


concrete slab floor. The office floor is covered with asphalt tile, and the exterior walls are covered with asbestos shakes. The building dimensions are provided in Table 3.11. A plan view of the facility is provided in Figure 3.15.

\section{Environmental Setting}

The environmental setting for this building is provided in Section 4.3.

\subsection{Chemical Separations Plant}

\section{Overview of Facility}

The representative chemical separations plant, similar to those constructed on the Hanford Site, is a spent fuel reprocessing facility used to separate plutonium from spent fuel for use in the nation's nuclear weapons program (Egge 1992; Keele et al. 1992; PNL 1975; Speer 1992). This building was placed in service in 1952 and retired in 1967. It was designed to reprocess irradiated

TABLE 3.11. Physical Description of the Office/Storage Building

\begin{tabular}{|l|c|c||}
\hline \multicolumn{1}{|c|}{ Dimensions } & Values & Units \\
\hline \hline Floor area & 64 & $\mathrm{~m}^{2}$ \\
\hline Length & 13.3 & $\mathrm{~m}$ \\
\hline Width & 4.8 & $\mathrm{~m}$ \\
\hline Height & 4 & $\mathrm{~m}$ \\
\hline
\end{tabular}




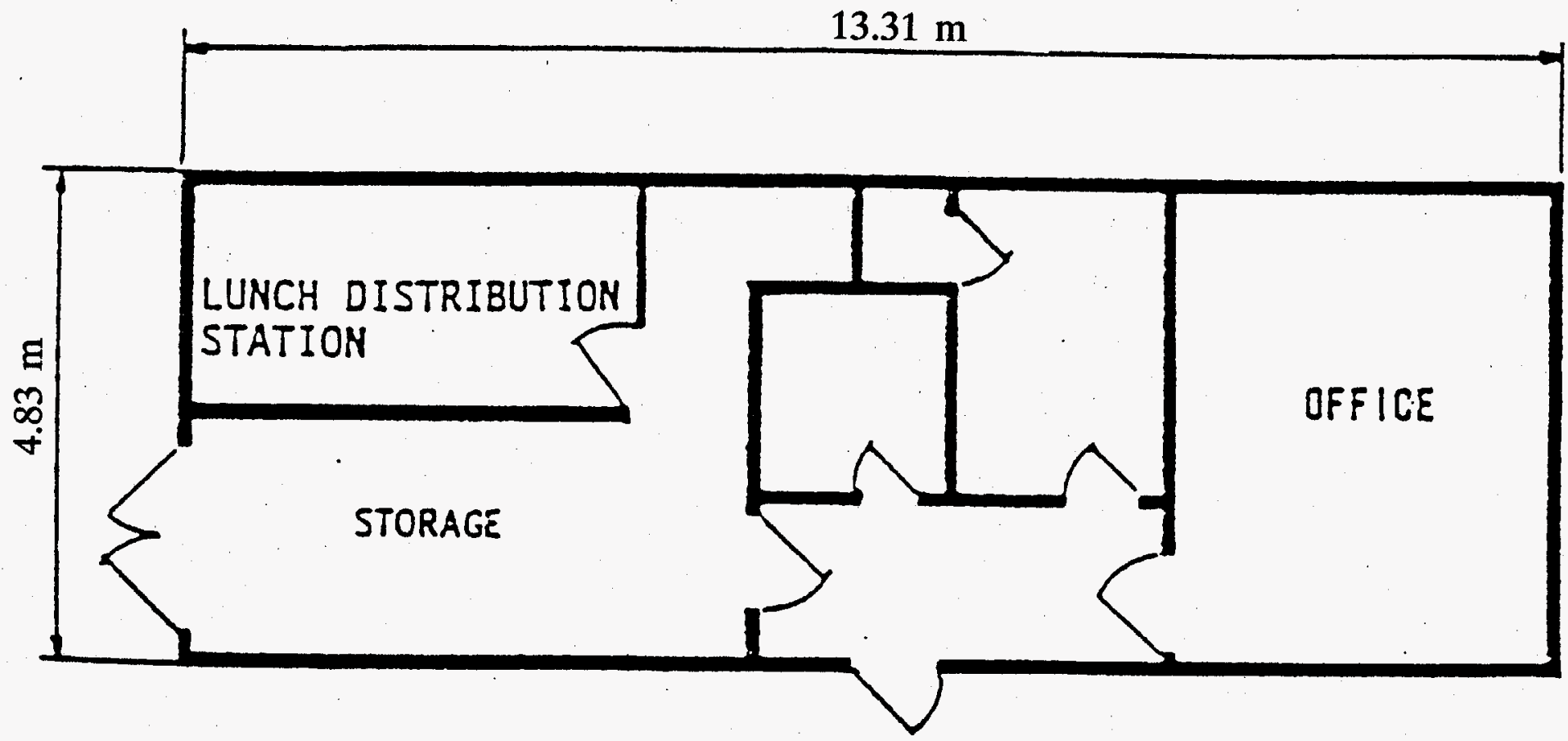

FIGURE 3.15. Plan View of the Office/Storage Building 
fuel from production reactors and to provide separate product streams of plutonium, neptunium, and uranium, as well as a waste stream of fission products. The process used a liquid-liquid solvent extraction process involving an aqueous nitric acid solution "salted" with aluminum nitrate to promote transfer of selected ions into the second liquid phase, hexone (methyl isobutyl ketone). The oxidation state of the aqueous solution was altered by chemical additions at selected stages of the process, to modify the solution equilibria between the two solutes for "target" ionic species, thus enhancing the separation process. This building is currently scheduled for decommissioning starting in 2004.

\section{Physical Description}

Figure 3.16 shows the location of the building relative to other surrounding facilities, and Figure 3.17 is a cutaway view of the building. A summary description of this facility is given in Table 3.12.

This building features a long, concrete "canyon," which contains the major portion of the process vessels and piping, and a tall "silo" that contains the packed columns used for solvent extraction operations. The process cells in the canyon are shielded by concrete walls up to $1.8 \mathrm{~m}$ thick. The process cells are arranged in two parallel rows within the canyon building; between the rows are a pipe tunnel, containing the piping interconnecting the process vessels in the building and carrying radioactive fluids, and a tunnel carrying exhaust air from the facility to a filter bank and stack. Paralleling each row of process cells, outside their shielding walls, are two vertical banks of service galleries used for operating the cells and providing needed services and utilities.

The silo, used primarily for partitioning the dissolved fuel into product and waste streams in the extraction columns, has external walls about $1 \mathrm{~m}$ thick. This tower is located at the west end of the canyon building and includes an 


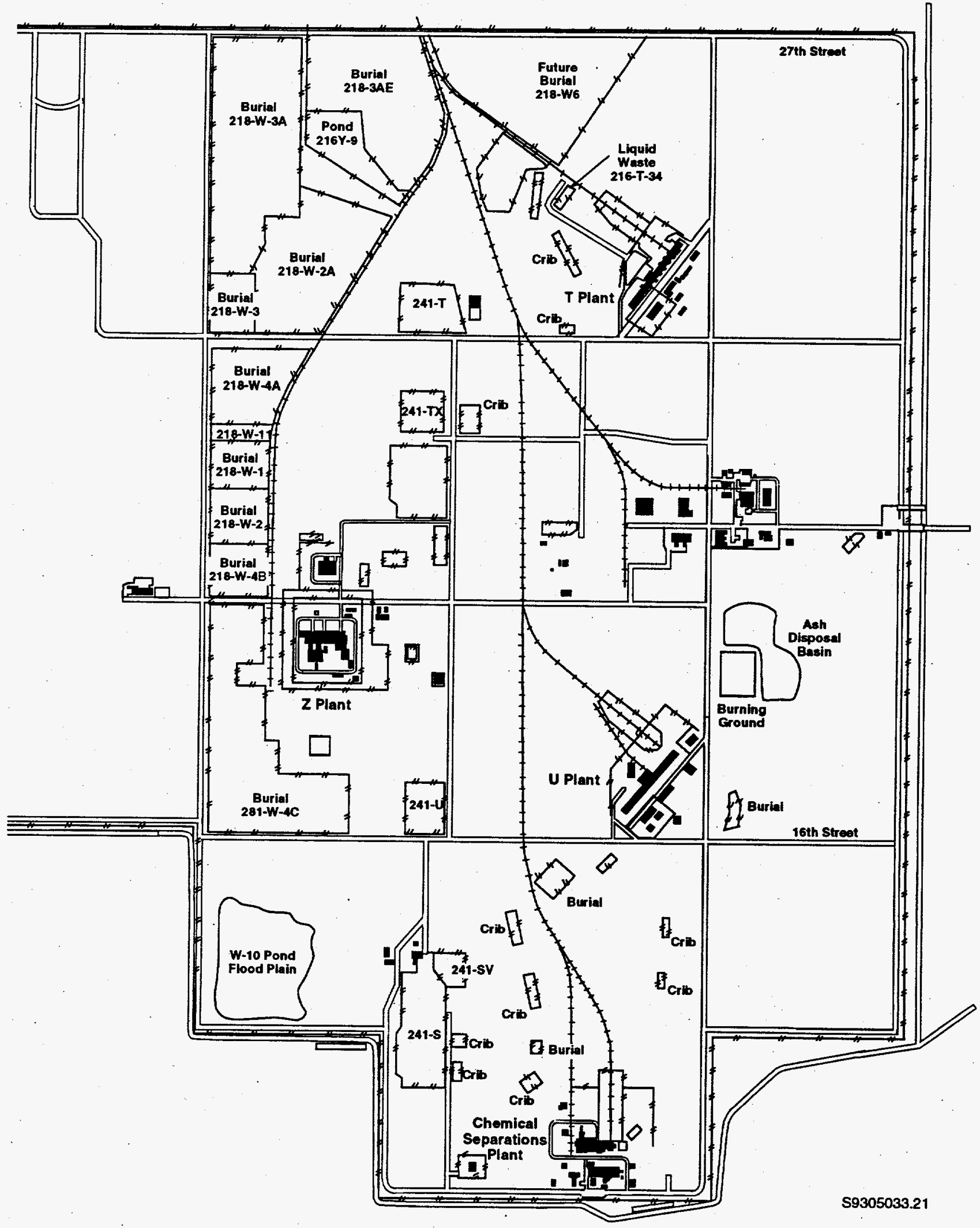

FIGURE 3.16. Location of Chemical Separations Building Relative to Other Buildings 


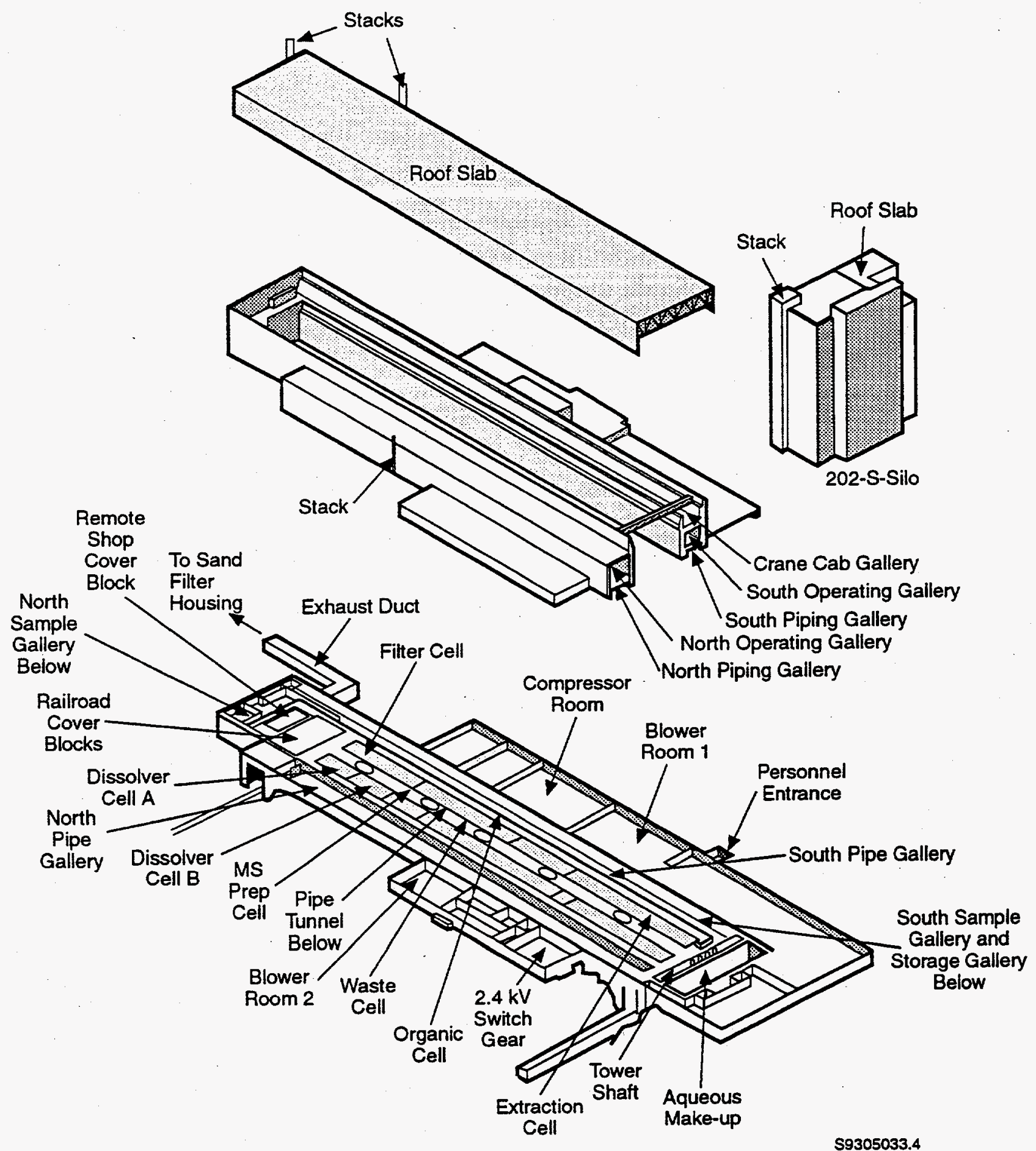

FIGURE 3.17. Cutaway View of the Chemical Separations Building 


\section{TABLE 3.12. Physical Description of the Chemical Separations Plant}

Type of construction: poured, reinforced concrete

Present integrity of the confinement structure: average

Active confinement systems required during storage: yes

Facility operations began: 1952

Facility operations ceased: 1967

\begin{tabular}{|l|c|c|}
\hline \multicolumn{1}{|c|}{ Description/Dimensions } & Values & Units \\
\hline \hline Grade elevation above sea level & 207 & $\mathrm{~m}$ \\
\hline Grade elevation above Standard Project Flood & 92 & $\mathrm{~m}$ \\
\hline Depth to groundwater & 65 & $\mathrm{~m}$ \\
\hline Maximum length & 142.5 & $\mathrm{~m}$ \\
\hline Maximum width & 49.1 & $\mathrm{~m}$ \\
\hline Maximum height (tower) & 38.5 & $\mathrm{~m}$ \\
\hline Maximum height (Canyon Bldg) & 19 & $\mathrm{~m}$ \\
\hline Maximum height (rest of bldg) & 5 to 11 & $\mathrm{~m}$ \\
\hline Maximum depth below grade & 7 & $\mathrm{~m}$ \\
\hline Floor thickness, shield & 1 to 1.7 & $\mathrm{~m}$ \\
\hline Non-shield & 0.15 to 1 & $\mathrm{~m}$ \\
\hline Wall thickness, shield & 1 to 1.7 & $\mathrm{~m}$ \\
\hline Non-shield & 0.3 to 1 & $\mathrm{~m}$ \\
\hline Total interior volume & 76,038 & $\mathrm{~m}^{3}$ \\
\hline "Heavy" concrete volume & $21,988.6$ & $\mathrm{~m}^{3}$ \\
\hline Total floor area & 13,929 & $\mathrm{~m}^{2}$ \\
\hline Building "footprint" area at ground level & $5,308.2$ & $\mathrm{~m}^{2}$ \\
\hline Wall construction & Concrete, concrete blocks, steel w/siding & \\
\hline
\end{tabular}

operating gallery for the extraction columns, sampling facilities, and multilevel process feed facilities for additions to the columns. An underground pit connecting to the tower provides for removal of expended columns from the tower and their replacement with fresh columns. 
A receiving facility for the spent fuel "feed" for the facility, as well as "hot" cells and special work permit (SWP) change facilities, is at the east end of the canyon building. Service and office facilities are constructed adjoining the west, south, and north sides of the production facility.

Underground piping carried the product plutonium solution to an adjacent building for concentration and shipment to plutonium "finishing" facilities. Uranyl nitrate product solutions (UNH) were piped to a storage facility for transfer to uranium recovery. The fission product wastes and dissolved cladding materials were piped to underground storage tanks.

The "grade" elevation of the building is $207 \mathrm{~m}$ above sea level. It is about $82 \mathrm{~m}$ above the Standard Project Flood (dam-regulated 500-year flood) and 60 to $65 \mathrm{~m}$ above the groundwater table.

For this source description, the building is described in terms of eight subfacilities, covered in subsequent pages. These subfacilities are the following:

- The canyon reprocessing cells

- The pipe tunnel and exhaust air tunnel, situated between the rows of canyon cells, and the waste tunnel that exits the north side of the building from the waste processing cell

- The service galleries, paralleling the canyon process cells

- The upper canyon, above the reprocessing cells 
- The silo column shaft, containing the extraction columns, the silo crane gallery directly above the shaft, and the extraction column removal facility

- The tower makeup and operating area

- The fuel receiving area, hot shops, and health physics facility

- The service wings.

\section{Description of Contamination}

The facility was highly successful, but it suffered from deterioration of gasket materials used in the processing vessels and piping, resulting in considerable leakage of the process liquids into the canyon cells. In addition, the piping and vessels in the plant accumulated considerable quantities of plutonium-containing sludge.

The process equipment, process cells, and adjacent area were flushed repeatedly with a series of cleaning solutions when the facility was deactivated in 1967; about $9.5 \mathrm{~kg}$ of plutonium were recovered in that operation. However, considerable plutonium is estimated to remain in the vessels and associated piping. Current estimates are that $1,500 \mathrm{Ci}$ (about 5,200 g) of plutonium still remain in the confines of the building, along with about 9,000 $\mathrm{Ci}$ of beta emitters. The isotopic composition of the plutonium (and accompanying neptunium and americium) are assumed to be the same as for the building that concentrated the separated plutonium. Since about 27 years have passed since shutdown of the 
facility, the radionuclides represented as "beta emitters" are assumed to consist primarily of longer-lived fission products dominated by strontium, cesium, and the longer-lived rare earths.

Prior to the decontamination of the equipment, radiation levels well above $1,000 \mathrm{rads}$ per hour $(\mathrm{rad} / \mathrm{hr})$ were reported in the process cells. Following the decontamination, the activity level had fallen from 100 to $500 \mathrm{rad} / \mathrm{hr}$ within the cells; with the shield plugs above the cells removed, levels of 5 to $10 \mathrm{rad} / \mathrm{hr}$ were obtained in the canyon floor above the cells. By 1974, the levels of radiation had fallen by a factor of 10. Radioactive decay has since lowered those levels further, but no recent measurements have been taken within the canyon cells.

The canyon process cells and extraction column shaft have remained sealed since the 1967 shutdown. The operating galleries in both the canyon and the tower have been monitored and maintained as "clean" areas, or areas of minimal contamination. In addition, the column makeup levels in the tower have only occasional regions of low-level contamination.

In the receiving end (east end) of the building, the remote hot cell may have moderate levels of contamination; initial deactivation procedures called for decontamination to below $100 \mathrm{mR} / \mathrm{hr}$ at $0.61 \mathrm{~m}$ from room surfaces. The decontamination room and regulated shop, adjacent to the remote shop, have low to moderate levels of contamination, as does the rail tunnel. The remainder of the east end rooms, which make up the health physics facility, have been largely decontaminated and maintained in clean status.

For purposes of this description, the radioactive contamination is assumed to be confined primarily to the currently excluded areas of the building: the process cells in the canyon, the adjacent "hot" pipe tunnel and exhaust air tunnel, and 
the extraction column shaft in the silo on the west end of the building (approximately $6-10 \%$ of the entire facility floor area). In lieu of characterization data for those areas, the contaminants are assumed to be apportioned approximately as:

\begin{tabular}{|c|c|c|c|}
\hline Contaminant & Process Cells & Tunnels & Extraction Tower \\
\hline Plutonium & $80 \%$ & $5 \%$ & $15 \%$ \\
\hline Fission Products & $85 \%$ & $10 \%$ & $5 \%$ \\
\hline
\end{tabular}

The amount of this contamination that is in a dispersable form, as opposed to being fixed to the facility surfaces, is currently unknown.

A summary of the contamination status of the building is shown in Table 3.13.

\section{Environmental Setting}

The environmental setting for this source term description is given in Section 4.3.

\subsubsection{Canyon Processing Cells}

\section{Physical Description}

The canyon, one of the major subdivisions of the building, is situated between the silo tower on the west end of the building and the receiving area on the east. The deck, the main operating floor of the canyon sector, is about $2.9 \mathrm{~m}$ above building grade. The canyon building extends about $7.3 \mathrm{~m}$ above the deck (as a single room) and $10.4 \mathrm{~m}$ below the deck surface. The process cells are a group of nine rectangular cavities in the concrete structure beneath the operating floor. These cells are $3.7 \mathrm{~m}$ in width, $8.4 \mathrm{~m}$ high, and from 8 to $32 \mathrm{~m}$ in 
TABLE 3.13. Principal Contaminants in the Chemical Separations Plant

\begin{tabular}{|c|c|c|c|c|c|c|}
\hline \multirow[b]{2}{*}{ Contaminant } & \multicolumn{2}{|c|}{ Quantity } & \multirow{2}{*}{$\begin{array}{l}\text { \% Total } \\
\text { Facility } \\
\text { Contam. }\end{array}$} & \multicolumn{2}{|c|}{ Activity } & \multirow[b]{2}{*}{$\begin{array}{c}\text { Activity } \\
\text { Survey Date }\end{array}$} \\
\hline & Values & Units & & Level & Unit & \\
\hline \multirow[t]{2}{*}{ Plutonium } & 1,500 & $\mathrm{Ci}$ & $6-10$ & & & 1992 \\
\hline & & & \multicolumn{4}{|c|}{$\begin{array}{l}\text { Assuming this plutonium is of the same isotopic mix } \\
\text { (including } \mathrm{Np} \text { and } \mathrm{Am} \text { ) as the plutonium processing } \\
\text { facility, the following mix is imputed: }\end{array}$} \\
\hline $\mathrm{Pu}-239$ & $4,870.8$ & $\mathrm{~g}$ & $6-10$ & 302.3 & $\mathrm{Ci}$ & \\
\hline $\mathrm{Pu}-240$ & 312.6 & $\mathrm{~g}$ & $6-10$ & 71.0 & $\mathrm{Ci}$ & \\
\hline $\mathrm{Pu}-241$ & 10.4 & $\mathrm{~g}$ & $6-10$ & $1,073.2$ & $\mathrm{Ci}$ & \\
\hline Am-241 & 15.6 & g & $6-10$ & 53.6 & $\mathrm{Ci}$ & \\
\hline $\mathrm{Np}-237$ & 10.9 & $g$ & $6-10$ & 8 & $\mathrm{mCi}$ & \\
\hline Beta emitters & 9,000 & $\mathrm{Ci}$ & $6-10$ & 9,000 & $\mathrm{Ci}$ & 1992 \\
\hline Gamma radiation & & & & $>1,000$ & $\mathrm{R} / \mathrm{hr}$ & $1967^{(\mathrm{a})}$ \\
\hline Gamma radiation & & & & $100-500$ & $\mathrm{R} / \mathrm{hr}$ & $1967^{(b)}$ \\
\hline Gamma radiation & & & & $10-50$ & $\mathrm{R} / \mathrm{hr}$ & $1974^{(\mathrm{c})}$ \\
\hline Asbestos & & \multicolumn{5}{|c|}{$\begin{array}{l}\text { Quantity of asbestos is uncertain. Asbestos was used for } \\
\text { lagging steam lines, other process lines, and for roofing } \\
\text { insulation. Any asbestos in process areas would be grossly } \\
\text { contaminated. Uncontaminated asbestos is scheduled for } \\
\text { removal under surveillance program. }\end{array}$} \\
\hline \multicolumn{7}{|c|}{$\begin{array}{l}\text { (a) Measured prior to decontamination of process equipment. } \\
\text { (b) Measured after process decontamination. } \\
\text { (c) Radiation level after decay to } 1974 \text {. }\end{array}$} \\
\hline
\end{tabular}

length; they are arrayed in two parallel rows on either side of a pipe tunnel that provides process connections to equipment in the cells.

The waste tunnel extends from the east end of the waste cell through the north side of the building and carries the process waste stream (fission products and cladding wastes) to waste storage tanks. For convenience in calculations, this subfacility is combined with the process cells. 
The equipment in the canyon cells includes about 65 vessels, consisting of fuel dissolvers, mixing vessels, heat exchangers, evaporators, filters, and pumps to move the fluids through the process. The actual partition of process fluids into product and waste streams occurred in packed solvent extraction columns in the tower silo, using hexone (methyl isobutyl ketone) as extractant. All other steps in dissolving the fuel, preparing feed to the columns, preparing the separated streams for delivery to adjacent buildings for further processing, and concentrating the waste stream for delivery to waste storage tanks took place in the canyon cells.

A plan view sketch of the cells is shown in Figure 3.18. Table 3.14 provides a summary description of the process cells.

\section{Description of Contamination}

During operation of the plant, the process cells became highly contaminated from leakage of process fluids, mainly through failed gaskets and "burping" dissolvers during early stages of operation and from leakage occurring during changeout of equipment. In addition, defective piping "jumpers" were on occasion dropped during their removal for replacement, and their remote retrieval from the canyon floor was impractical. Following removal of the plant from operation in 1966, the process lines and vessels were put through a "terminal run" in 1967 to process all fluids left in the lines, then cleaned out using several successive chemical flushes. At the same time, the exterior surfaces of the equipment and piping, the cells, the tower silo, and the pipe tunnel and air exhaust tunnel were cleaned with remotely applied decontaminating solutions. During decontamination, about $9.5 \mathrm{~kg}$ of plutonium were recovered, along with over one-hundred kilograms (kg) of uranium. 


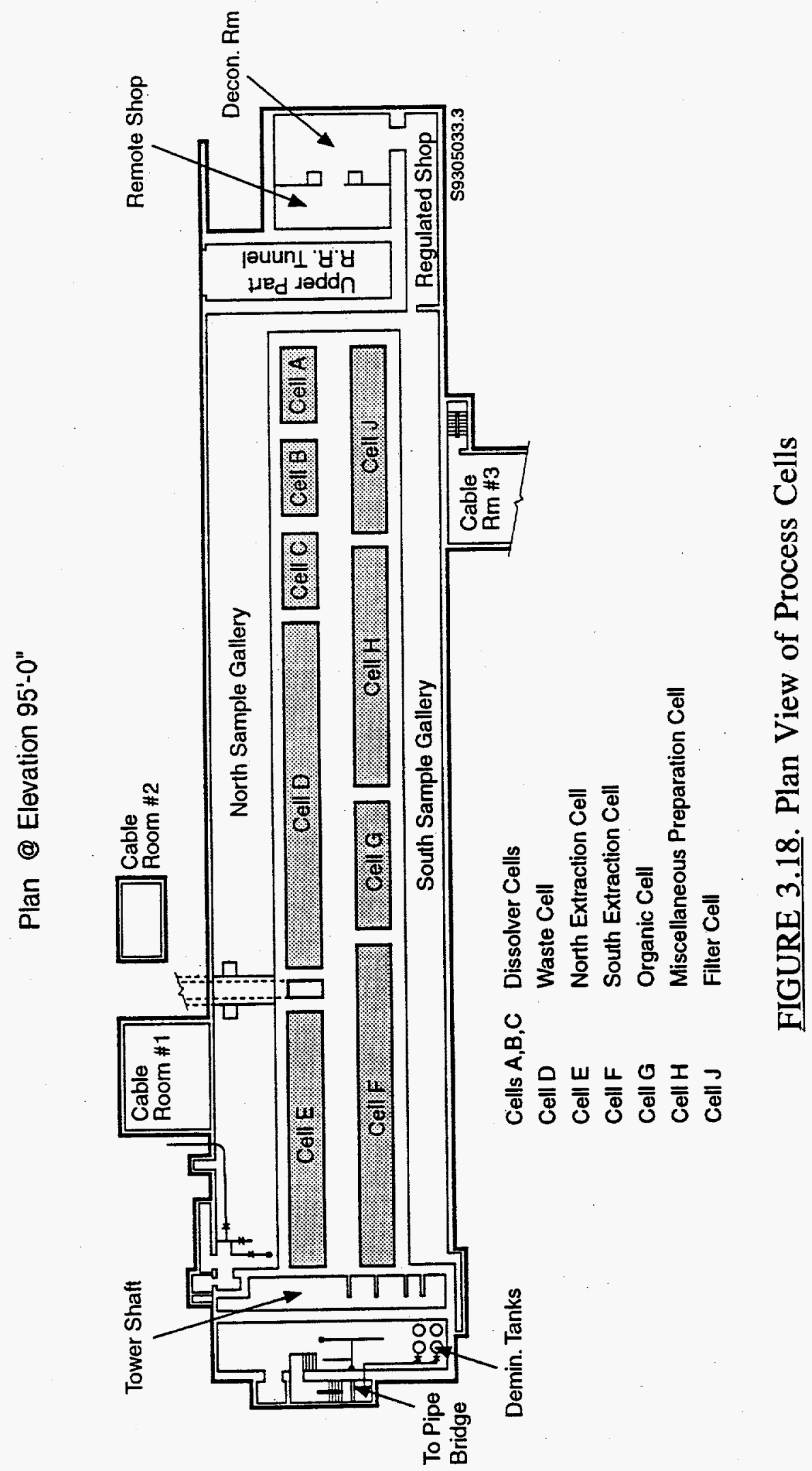


TABLE 3.14. Physical Description of the Canyon Process Cells

\begin{tabular}{|c|c|c|}
\hline Description/Dimensions & Values & Units \\
\hline Number of cells & 9 & \\
\hline Floor area & 645 & $\mathrm{~m}^{2}$ \\
\hline Length & Varies; 8 to 36.5 & $\mathrm{~m}$ \\
\hline Width & 3.7 & $\mathbf{m}$ \\
\hline Height & 6.1 to 8.4 & $\mathbf{m}$ \\
\hline Maximum height above grade & 1.7 & $\mathrm{~m}$ \\
\hline Maximum depth below grade & 6.7 & $\mathbf{m}$ \\
\hline Floor thickness & 0.3 & $\mathbf{m}$ \\
\hline Wall thickness, opposite galleries and at end of cells & 1.5 to 1.7 & $\mathbf{m}$ \\
\hline Wall thickness, opposite pipe tunnel & 0.5 & $\mathbf{m}$ \\
\hline Ceiling thickness & 1.2 & $\mathrm{~m}$ \\
\hline Ceiling construction & \multicolumn{2}{|c|}{$\begin{array}{l}\text { Removable concrete shield plugs in } \\
\text { canyon floor above }\end{array}$} \\
\hline Waste tunnel height & 1.5 & $\mathrm{~m}$ \\
\hline Waste tunnel width & 1.83 & $\mathbf{m}$ \\
\hline Waste tunnel length (within building) & 12 & $\mathrm{~m}$ \\
\hline Total interior volume & $5,260.7$ & $\mathrm{~m}^{3}$ \\
\hline "Heavy" concrete volume & 7,583 & $\mathrm{~m}^{3}$ \\
\hline Total floor surface & 644.6 & $\mathrm{~m}^{2}$ \\
\hline Cell contents & \multicolumn{2}{|c|}{$\begin{array}{l}\text { Grossly contaminated process } \\
\text { equipment and piping }\end{array}$} \\
\hline Equipment piping & \multicolumn{2}{|c|}{$\begin{array}{l}\text { Remotely installed jumpers to ports } \\
\text { through side wall to pipe tunnel }\end{array}$} \\
\hline Cell construction & \multicolumn{2}{|c|}{ Heavy reinforced concrete } \\
\hline
\end{tabular}

Following the terminal run and system decontamination, radiation levels in the process cell (initially well above $1,000 \mathrm{rad} / \mathrm{hr}$ ) were lowered by about a factor of 10 , although readings of up to $500 \mathrm{rad} / \mathrm{hr}$ were made in some of the cells. It is estimated that about $1,500 \mathrm{Ci}$ of plutonium remain in the building, along with considerable quantities of uranium and about $9,000 \mathrm{Ci}$ of beta emitters, assumed 
to be mixed fission products. Virtually all of this remaining contamination is in the process equipment, the canyon process cells and waste tunnel, the pipe and exhaust air tunnels, and the portion of the silo containing the extraction columns.

Table 3.15 summarizes the contamination status of the canyon cells.

TABLE 3.15. Principal Contaminants in Canyon Process Cells

\begin{tabular}{|c|c|c|c|c|c|c|}
\hline \multirow[b]{2}{*}{ Contaminant } & \multirow[b]{2}{*}{ Values } & \multirow[b]{2}{*}{ Units } & \multirow{2}{*}{$\begin{array}{l}\% \text { Total } \\
\text { Facility } \\
\text { Contam. }\end{array}$} & \multicolumn{2}{|c|}{ Activity } & \multirow{2}{*}{$\begin{array}{l}\text { Activity } \\
\text { Survey } \\
\text { Date }\end{array}$} \\
\hline & & & & Level & Unit & \\
\hline \multirow[t]{2}{*}{ Plutonium } & 1,200 & $\mathrm{Ci}$ & \multicolumn{3}{|c|}{$\begin{array}{l}\text { Assumed to contain }-80 \% \text { of total } \\
\text { facility Pu contamination and } 85 \% \\
\text { of fission products }\end{array}$} & 1992 \\
\hline & & & \multicolumn{4}{|c|}{$\begin{array}{l}\text { Assuming this plutonium is of the same isotopic } \\
\text { mix (including Np and Am) as the plutonium } \\
\text { processing facility, the following mix is } \\
\text { imputed: }\end{array}$} \\
\hline $\mathrm{Pu}-239$ & 3,896 & $\mathrm{~g}$ & 80 est & 241.8 & $\mathrm{Ci}$ & \\
\hline $\mathrm{Pu}-240$ & 250 & $\mathrm{~g}$ & 80 est & 56.8 & $\mathrm{Ci}$ & \\
\hline $\mathrm{Pu}-241$ & 8.3 & $\mathbf{g}$ & 80 est & 858.6 & $\mathrm{Ci}$ & \\
\hline Am-241 & 12.5 & $g$ & 80 est & 42.9 & $\mathrm{Ci}$ & \\
\hline Np-237 & 8.7 & $\mathrm{~g}$ & 80 est & 6.4 & $\mathrm{mCi}$ & \\
\hline \multirow[t]{2}{*}{ Beta emitters } & 7,650 & $\mathrm{Ci}$ & 85 est & 7,650 & $\mathrm{Ci}$ & 1992 \\
\hline & & & \multicolumn{4}{|c|}{$\begin{array}{l}\text { The beta emitters are assumed to represent the } \\
\text { remnants of the fission products in the fuel at } \\
\text { the time of reprocessing. }\end{array}$} \\
\hline Gamma radiation & & & & $>1,000$ & $\mathrm{R} / \mathrm{hr}$ & $1967^{(\mathrm{a})}$ \\
\hline Gamma radiation & & & & $100-500$ & $\mathrm{R} / \mathrm{hr}$ & $1967^{(\mathrm{b})}$ \\
\hline Gamma radiation & & & & $10-50$ & $\mathrm{R} / \mathrm{hr}$ & $1974^{(\mathrm{c})}$ \\
\hline Asbestos & Unk. & Unk. & & & & \\
\hline \multicolumn{7}{|c|}{$\begin{array}{l}\text { (a) Measured prior to decontamination of process equipment. } \\
\text { (b) Measured after process decontamination. } \\
\text { (c) Radiation level after decay to } 1974 \text {. }\end{array}$} \\
\hline
\end{tabular}




\subsubsection{Pipe Tunnel and Air Tunnel}

\section{Physical Description}

The pipe tunnel and the air tunnel underneath it run the length of the canyon between the rows of process cells and extend into the tower at the west end of the building. The pipe tunnel contains lengths of pipe that interconnect equipment in the various cells and the extraction columns in the tower and remove product and waste streams from the process areas. Pipeline terminations within the tunnel are to junctions with lines penetrating the side walls of the tunnel for remote connection to the process equipment.

The air tunnel, running beneath the pipe tunnel, extends into the tower and removes contaminated air from the process cells and the tower shaft containing the extraction columns and the pipe tunnel. At the east end of the canyon, the air tunnel leaves the building; it continues under ground to the filter station and thence to the stack. In the balanced-pressure ventilation system providing atmospheric confinement to the building, the areas connecting directly to the air tunnel are maintained at the lowest pressures.

Drain and vent passages are provided at the base of the wall separating the pipe tunnel from the north process cells, to provide air flow from the tunnel into the cells and carry any free liquid in the tunnel into sumps within the cells. A second set of drains and vents carries any liquids from the air tunnel to both the north and south cell sumps and vents the cells to the air tunnel.

Table 3.16 provides a summary description of the tunnels. 
TABLE 3.16. Physical Description of the Canyon Tunnels

\begin{tabular}{|c|c|c|}
\hline Description/Dimensions & Values & Units \\
\hline Number of tunnels & 2 & \\
\hline Pipe tunnel location & $\begin{array}{l}\text { Between rows of process } \\
\text { cells, beneath canyon floor }\end{array}$ & \\
\hline Air tunnel location & $\begin{array}{l}\text { Beneath pipe tunnel, extends } \\
\text { into tower }\end{array}$ & \\
\hline Floor area & 621 & $\mathrm{~m}^{2}$ \\
\hline Length, pipe tunnel & 105 & m \\
\hline Length, air tunnel & 129 & $\mathbf{m}$ \\
\hline Width & 2.9 & $\mathrm{~m}$ \\
\hline Height, pipe tunnel & 3.8 & m \\
\hline Height, air tunnel & 0.9 & $\mathrm{~m}$ \\
\hline Max. height above grade (pipe tunnel) & 1.7 & $\mathrm{~m}$ \\
\hline Max. depth below grade (air tunnel) & 6.7 & $\mathrm{~m}$ \\
\hline Floor thickness & 0.3 & m \\
\hline Wall thickness, opposite pipe tunnel & 0.5 & $\mathrm{~m}$ \\
\hline Ceiling thickness & 1.2 & $\mathbf{m}$ \\
\hline Ceiling construction & \multicolumn{2}{|c|}{$\begin{array}{l}\text { Concrete (floor of canyon above) with } \\
\text { removable concrete shield plugs. }\end{array}$} \\
\hline Total interior volume & 2,170 & $\mathrm{~m}^{3}$ \\
\hline "Heavy" concrete volume & 7,583 & $\mathrm{~m}^{3}$ \\
\hline Total floor surface & 644.6 & $\mathrm{~m}^{2}$ \\
\hline Pipe tunnel contents & \multicolumn{2}{|c|}{ Grossly contaminated process piping } \\
\hline Tunnel construction & \multicolumn{2}{|l|}{ Concrete } \\
\hline
\end{tabular}

\section{Description of Contamination}

The pipe tunnel and air tunnel both accumulated considerable contamination during the life of the plant. Pipe leaks within the pipe tunnel resulted in high contamination levels. The air tunnel receives contaminated air from the entire building and on occasion has received "blowover" liquid from air jet discharge lines; both tunnels are considered highly contaminated areas. 
Table 3.17 shows estimates of contamination in the pipe and exhaust air tunnels.

\subsubsection{Canyon Galleries}

\section{Physical Description}

Galleries used in operating the canyon cells and providing essential services to the cells are located outside the outer shielding walls of the cells, running the length of the cells and connecting to facilities on both ends of the canyon building. The galleries are arranged vertically on each side of the cells and are used

TABLE 3.17. Principal Contaminants in the Pipe and Exhaust Air Tunnels

\begin{tabular}{|c|c|c|c|c|c|c|}
\hline \multirow[b]{2}{*}{ Contaminant } & \multirow[b]{2}{*}{ Values } & \multirow[b]{2}{*}{ Units } & \multirow{2}{*}{$\begin{array}{l}\% \text { Total } \\
\text { Facility } \\
\text { Contam. }\end{array}$} & \multicolumn{2}{|c|}{ Activity } & \multirow{2}{*}{$\begin{array}{l}\text { Activity } \\
\text { Survey } \\
\text { Date }\end{array}$} \\
\hline & & & & Level & Unit & \\
\hline \multirow[t]{2}{*}{ Plutonium } & 75 & $\mathrm{Ci}$ & \multicolumn{3}{|c|}{$\begin{array}{l}\text { Assumed to contain } \sim 5 \% \text { of total facil- } \\
\text { ity Pu contamination, } 10 \% \text { of total fis- } \\
\text { sion products }\end{array}$} & 1992 \\
\hline & & & \multicolumn{4}{|c|}{$\begin{array}{l}\text { Assuming this plutonium is of the same isotopic mix } \\
\text { (including } \mathrm{Np} \text { and } \mathrm{Am} \text { ) as in the } 233-\mathrm{S} \text { Building, the } \\
\text { following mix is imputed: }\end{array}$} \\
\hline $\mathrm{Pu}-239$ & 243.5 & g & 80 est & 15.1 & $\mathrm{Ci}$ & \\
\hline $\mathrm{Pu}-240$ & 15.63 & $\mathrm{~g}$ & 80 est & 3.6 & $\mathrm{Ci}$ & \\
\hline Pu-241 & 0.52 & $\mathrm{~g}$ & 80 est & 53.7 & $\mathrm{Ci}$ & \\
\hline Am-241 & 0.78 & $\mathrm{~g}$ & 80 est & 2.7 & $\mathrm{Ci}$ & \\
\hline Np-237 & 0.55 & g & 80 est & 0.4 & $\mathrm{mCi}$ & \\
\hline \multirow[t]{2}{*}{ Beta emitters } & 900 & $\mathrm{Ci}$ & 85 est & 900 & $\mathrm{Ci}$ & 1992 \\
\hline & & & \multicolumn{4}{|c|}{$\begin{array}{l}\text { The beta emitters are assumed to represent the } \\
\text { remnants of the fission products in the fuel at the } \\
\text { time of reprocessing. }\end{array}$} \\
\hline Asbestos & Unk. & Unk. & & & & \\
\hline
\end{tabular}


for (in top-to-bottom order) 1) process operation control, 2) nonradioactive piping serving the process equipment, 3) sampling of process fluids, and 4) (on the south side only) a storage gallery. A fifth gallery, running along the south canyon wall above the south operating gallery and open to the upper canyon area, is provided to shield the canyon crane cab that travels within that gallery. Cross-canyon passageways connect the two banks of galleries.

The south side galleries occupy the space between the process cell shield wall and the south wall of the canyon building. On the north side, the process cells use the north canyon wall for a shield; the galleries are located outside the canyon wall proper, in an extension to the building.

Table 3.18 gives a summary description of the canyon galleries.

\section{Description of Contamination}

During operation, the canyon galleries were maintained as low-level or clean areas. All levels were working areas, and the pipe galleries handled only nonradioactive fluids being introduced to the canyon cells. The cells have been monitored and maintained on a regular basis since the facility was shut down in 1967.

Recent surveys indicate the presence of transuranic (TRU) contamination in the sample galleries and moderate levels in the south operating gallery. Apart from those, only low-level contamination appears to be present.

The roof over the north galleries is of concrete, covered by about $75 \mathrm{~mm}$ of asbestos-containing insulation compound. The asbestos is reported to be scheduled for removal under the building maintenance program and, therefore, would not be included as part of a D\&D activity.

Table 3.19 presents principal contaminants in the canyon galleries. 
TABLE 3.18. Physical Description of the Canyon Galleries

\begin{tabular}{|c|c|c|}
\hline Description/Dimensions & Values & Units \\
\hline Number of galleries, south side & 5 & \\
\hline Number of galleries, north side & 3 & \\
\hline Length, south side & 94.9 to 118.1 & $\mathbf{m}$ \\
\hline Length, north side & 97.5 to 108.5 & $\mathrm{~m}$ \\
\hline Width, south side & 3.86 to 3.94 & $\mathrm{~m}$ \\
\hline Width, north side & 5.5 & m \\
\hline Height, south side & 18.31 & $\mathrm{~m}$ \\
\hline Height, north side & 12.95 & m \\
\hline Maximum height above grade, south side & 11.38 & $\mathbf{m}$ \\
\hline Maximum height above grade, north side & 10.52 & $\mathbf{m}$ \\
\hline Maximum depth below grade, south side & 6.93 & $\mathrm{~m}$ \\
\hline Maximum depth below grade, north side & 2.44 & $\mathrm{~m}$ \\
\hline Floor thickness & 0.3 to 0.46 & $\mathbf{m}$ \\
\hline Ceiling thickness, north side & 0.46 & m \\
\hline Ceiling construction & \multicolumn{2}{|c|}{ Concrete $\mathrm{w} / 76 \mathrm{~mm}$ asbestos compound } \\
\hline Total interior volume & $12,329.8$ & $\mathrm{~m}^{3}$ \\
\hline Concrete volume & $5,102.6$ & $\mathrm{~m}^{3}$ \\
\hline Floor area & $1,525.5$ & $\mathrm{~m}^{2}$ \\
\hline Cell contents & \multicolumn{2}{|c|}{$\begin{array}{l}\text { Control panels, wiring, instr. tubing; } \\
\text { electrical panels }\end{array}$} \\
\hline Equipment piping & \multicolumn{2}{|c|}{ Nonradioactive piping in pipe gallery } \\
\hline Cell construction & \multicolumn{2}{|l|}{ Concrete } \\
\hline
\end{tabular}


TABLE 3.19. Principal Contaminants in Canyon Galleries

\begin{tabular}{||l|l|l|}
\hline \multicolumn{1}{|c|}{ Contaminant } & \multicolumn{1}{|c|}{ Values } & Units \\
\hline \hline $\begin{array}{l}\text { Radioactive } \\
\text { Contaminants }\end{array}$ & $\begin{array}{l}\text { Little if any contamination is expected, except in the sample } \\
\text { galleries (alpha radiation) and the south operating gallery } \\
\text { (moderate contamination). The galleries have been regularly } \\
\text { surveyed since shutdown. }\end{array}$ & \\
\hline Asbestos & $\begin{array}{l}\text { Steam lines and possibly other lines in pipe gallery may have } \\
\text { asbestos lagging. }\end{array}$ & \\
\hline
\end{tabular}

\subsubsection{Upper Canyon}

\section{Physical Description}

The upper canyon, that portion of the canyon building above the canyon deck (the floor above the process cells), is a single room, the canyon hall, running the length of the canyon building. This room has two subcomponents: the shielded canyon and the canyon subroof space. The shielded canyon extends $8.5 \mathrm{~m}$ above the deck, overlying the canyon cells, tunnels, and south galleries, a railroad tunnel serving as the receiving point for spent fuel entering the reprocessing cells, and a remote "hot" shop. The canyon subroof space, above the shielded canyon, extends the length of the building. A 60-ton crane runs the length of the subroof space; a crane maintenance area east of the shielding walls extends to the east end of the building and connects to the crane cab gallery along the south side of the building.

The canyon deck is a massive concrete slab $1.2 \mathrm{~m}$ thick, $110.6 \mathrm{~m}$ long, and $12.4 \mathrm{~m}$ wide. A continuous line of stepped concrete shield plugs, also $1.2 \mathrm{~m}$ thick, is placed in the deck above each of the lines of process cells. Six additional shield plugs provide entry to the pipe tunnel, and the remote shop at the 
east end of the canyon has two additional plugs. The entire length of the railroad tunnel within the canyon is covered by removable steel plates at deck level.

The shielding wall at the south side of the shielded canyon is $1.17 \mathrm{~m}$ thick up to the level of the crane cab gallery, $6.9 \mathrm{~m}$ above the deck. Above that level, it tapers to a thickness of $0.6 \mathrm{~m}$, forming the wall of the crane cab gallery and extending to $8.5 \mathrm{~m}$ above the deck. At the east side, the shielding wall is $1.2 \mathrm{~m}$ thick up to the crane maintenance platform, then increases to $0.6 \mathrm{~m}$ thick, up to its maximum height of $6.9 \mathrm{~m}$.

The subroof space of the canyon building, above the shielded canyon, covers the entire length and width of the building (118.8 by $18.6 \mathrm{~m})$. It extends upward to the roof, $16 \mathrm{~m}$ above the canyon deck.

The two side walls of the building are each $25.8 \mathrm{~m}$ in overall height $(19 \mathrm{~m}$ above grade). The south wall is $0.9 \mathrm{~m}$ thick up to the level of the crane rails, then steps down to $0.46 \mathrm{~m}$ for another $4.4 \mathrm{~m}$, where it steps to $0.2 \mathrm{~m}$, forming a support for the roof trusses. It then continues $2.9 \mathrm{~m}$ further to roof level. The north wall is $1.5 \mathrm{~m}$ thick below the canyon floor, then drops to $1.17 \mathrm{~m}$ thick up to the level of the crane. Above this point, it is identical to the south wall.

The east wall of the building is $25.5 \mathrm{~m}$ high and $19.5 \mathrm{~m}$ wide. It is $0.46 \mathrm{~m}$ thick throughout.

The roof, $130 \mathrm{~m}$ by $19.5 \mathrm{~m}$, is constructed of concrete and is $23 \mathrm{~cm}$ thick. It is coated with asbestos-containing insulating compound $75 \mathrm{~mm}$ thick. This roof is the largest single asbestos source in the building. The roof is supported by a system of steel trusses anchored to the side walls.

A summary description of the upper canyon is given in Table 3.20. 
TABLE 3.20. Physical Description of the Upper Canyon

\begin{tabular}{|c|c|c|}
\hline Description/Dimensions & Values & Units \\
\hline \multicolumn{3}{|l|}{ Shielded canyon } \\
\hline Length & 110.6 & $\mathrm{~m}$ \\
\hline Width & 12.4 & $\mathbf{m}$ \\
\hline Height above deck & 8.5 & $\mathrm{~m}$ \\
\hline Maximum height above grade & 11.4 & $\mathrm{~m}$ \\
\hline Deck thickness & 1.2 & m \\
\hline Deck construction & \multicolumn{2}{|c|}{$\begin{array}{l}\text { Concrete slab; shield plugs over canyon } \\
\text { cells, pipe tunnel, remote cell; steel } \\
\text { plates over RR Tunnel }\end{array}$} \\
\hline Deck surface area & 1,372 & $\mathbf{m}^{2}$ \\
\hline Shielded canyon interior volume & 11,662 & $\mathrm{~m}^{3}$ \\
\hline \multicolumn{3}{|l|}{ Canyon subroof space } \\
\hline Length & 118.0 & $\mathbf{m}$ \\
\hline Width & 18.6 & $\mathrm{~m}$ \\
\hline Height & 7.5 & $\mathrm{~m}$ \\
\hline $\begin{array}{l}\text { Canyon subroof interior volume (Includes crane } \\
\text { galley and maint. area) }\end{array}$ & 18,142 & $\mathrm{~m}^{3}$ \\
\hline \multicolumn{3}{|l|}{ Canyon building roof } \\
\hline Length & 118.4 & $\mathbf{m}^{3}$ \\
\hline Width & 19.5 & $\mathrm{~m}^{2}$ \\
\hline Thickness & 0.23 & m \\
\hline Maximum height above grade & 18.9 & $\mathrm{~m}$ \\
\hline Roof area & $2,308.8$ & $\mathrm{~m}^{2}$ \\
\hline Roof construction & \multicolumn{2}{|c|}{$\begin{array}{l}\text { Concrete slab, covered with } 8 \mathrm{~mm} \\
\text { asbestos insulation compound }\end{array}$} \\
\hline Total interior volume & 29,804 & $\mathrm{~m}^{3}$ \\
\hline Total concrete volume & 11,318 & $\mathbf{m}^{3}$ \\
\hline Total asbestos compound volume & 175.9 & $\mathrm{~m}^{3}$ \\
\hline
\end{tabular}




\section{Description of Contamination}

The contamination levels within the canyon have not been surveyed recently but are believed to be relatively low. During operation, the canyon floor was subject to contamination. However, it was washed down frequently with water sprays from nozzles installed along the ceiling. During the post-shutdown decontamination, it was flushed with potassium permanganate and oxalic acid. Although technically outside the confinement zone, the canyon deck has been inaccessible for routine monitoring in recent years; the present state of contamination is therefore not known. It is unlikely that any high levels of contamination would remain, but this is uncertain. Since the canyon was directly exposed to the process cells during phases of the facility operation, it is likely that the contamination present includes TRU isotopes.

Table 3.21 presents the estimates of contamination in the upper canyon.

\subsubsection{Tower Extraction Column Shaft}

\section{Physical Description}

The east end of the silo, adjacent to the canyon process cells, contains a single opening, the tower extraction column shaft, to accommodate 13 packed solvent extraction columns. The columns are from 9.75 to $16.75 \mathrm{~m}$ in height and from 8 to $25 \mathrm{~cm}$ in diameter. They are aligned vertically, side by side, on the east wall of the shaft. Four vertical shielding walls, $30.5 \mathrm{~cm}$ thick and $2 \mathrm{~m}$ in width, extend from the east wall of the shaft to provide auxiliary shielding for the columns used in partition of waste products from the dissolved fuel.

The west and north walls of the shaft are provided with radiation-absorbing viewing windows to allow visual observation of the columns and their associated piping. 
TABLE 3.21. Principal Contaminants in Upper Canyon

\begin{tabular}{||l|l|l|}
\hline \multicolumn{1}{|c|}{ Contaminant } & \multicolumn{1}{|c|}{ Values } & Units \\
\hline \hline $\begin{array}{l}\text { Radioactive } \\
\text { contaminants }\end{array}$ & $\begin{array}{l}\text { The canyon deck may have some residual contamination, but } \\
\text { there are no data. Upper reaches of the canyon should have } \\
\text { little if any contamination. }\end{array}$ & \\
\hline Asbestos & $\begin{array}{l}\text { About } 176 \text { cubic meters of asbestos roofing compound, } \\
\text { probably reasonably well fixed. }\end{array}$ & \\
\hline
\end{tabular}

Directly above the column shaft is a crane gallery containing a 10-ton crane, which was used for remote maintenance and replacement of the columns and piping attachments. The crane has been left in operating condition.

A pair of rails is mounted on the floor of the canyon shaft and runs through a short tunnel to the column disposal pit outside the north side of the silo.

Expended extraction columns were disconnected from facility piping and drained, then laid horizontally on rail-mounted column carriers by the silo crane and moved out to the removal pit.

From the pit they were removed in shielded casks for product recovery and column disposal. Replacement columns were taken into the column shaft using the rail carriers and mounted.

A summary description of the column shaft and column removal system is given in Table 3.22 .

\section{Description of Contamination}

Contamination of the column shaft resulted from basically the same causes as the canyon cells. Leakage from equipment and piping and from replacing 
TABLE 3.22. Physical Description of the Tower Extraction Column Shaft

\begin{tabular}{|c|c|c|}
\hline Description/Dimensions & Values & Units \\
\hline \multicolumn{3}{|l|}{ Column shaft } \\
\hline Floor area & 69.7 & $\mathrm{~m}^{2}$ \\
\hline Length & 20.6 & $\mathbf{m}$ \\
\hline Width & 3.5 & m \\
\hline Height & 25.8 & $\mathbf{m}$ \\
\hline Maximum height above grade & 21.1 & $\mathrm{~m}$ \\
\hline Maximum depth below grade & 1.45 & $\mathbf{m}$ \\
\hline Floor thickness & 0.3 & $\mathrm{~m}$ \\
\hline Wall thickness - west, south, east & 1 & $\mathrm{~m}$ \\
\hline Wall thickness - north & 0.3 & $\mathbf{m}$ \\
\hline Column shield volume & 62.3 & $\mathrm{~m}^{3}$ \\
\hline Shaft interior volume & $1,051.4$ & $\mathrm{~m}^{3}$ \\
\hline Concrete volume & 1.838 .9 & $\mathbf{m}^{3}$ \\
\hline Cell contents & \multicolumn{2}{|c|}{$\begin{array}{l}\text { Grossly contaminated process } \\
\text { equipment and piping }\end{array}$} \\
\hline Equipment piping & \multicolumn{2}{|c|}{$\begin{array}{l}\text { Remotely installed jumpers to ports } \\
\text { through side wall to pipe tunnel }\end{array}$} \\
\hline \multicolumn{3}{|l|}{ Silo crane gallery } \\
\hline Floor area & 250.5 & $\mathrm{~m}^{2}$ \\
\hline Length & 24.5 & $\mathbf{m}$ \\
\hline Width & 10.2 & $\mathbf{m}$ \\
\hline Height & 4.9 & $\mathbf{m}$ \\
\hline Max. height above grade & 26.6 & m \\
\hline Floor thickness & 0.15 & $\mathbf{m}$ \\
\hline Floor construction & \multicolumn{2}{|c|}{$\begin{array}{l}\text { Concrete; metal covers over } \\
\text { column shaft }\end{array}$} \\
\hline Wall thickness - east, west & 1.07 & $\mathbf{m}$ \\
\hline Wall thickness - north, south & 0.46 & m \\
\hline
\end{tabular}


TABLE 3.22. (Contd)

\begin{tabular}{||l|c|c||}
\hline \multicolumn{1}{|c|}{ Description/Dimensions } & Values & Units \\
\hline \hline Silo crane gallery (cont). & & \\
\hline Crane gallery interior volume & $1,241.8$ & $\mathrm{~m}^{3}$ \\
\hline Crane gallery concrete volume & 314.6 & $\mathrm{~m}^{3}$ \\
\hline Crane gallery contents & 110 -ton crane & \\
\hline Total subfacility floor area & 320.2 & $\mathrm{~m}^{2}$ \\
\hline Total subfacility interior volume & $2,293.2$ & $\mathrm{~m}^{3}$ \\
\hline Total subfacility concrete volume & $2,153.5$ & $\mathrm{~m}^{3}$ \\
\hline
\end{tabular}

spent columns subjected the shaft to fluids containing plutonium and other transuranic elements, uranium, and fission products. Because of the smaller size and relative simplicity of equipment in the shaft, less contamination was probably received here than in the canyon process cells. Fission product contamination would be relatively less severe than in the canyons, because only a few of the columns in the shaft were used in fission product partition.

The column carrier tunnel adjoins the lower part of the shaft column and shares a common floor surface. Those portions of the tunnel within the confines of the silo structure would therefore be expected to have contamination levels similar to those in the shaft column. The outer end of the tunnel is closed by a steel door at the column carrier outlet pit. It is not known how effective this door is at inhibiting spread of contamination out of the shaft column, or whether additional sealing was applied to provide further inhibition of spreading. Contamination, including TRU contamination, may persist in the pit area.

Similarly, the silo crane gallery probably received moderate contamination during the period of operations; however, it is accessible for decontamination (the 
crane is maintained in operable condition), and current levels of contamination should be relatively low. The crane gallery is indicated to be TRUcontaminated.

An estimate of contamination in the shaft is given in Table 3.23.

\subsubsection{Tower Column Makeup and Operating Facilities}

\section{Physical Description}

The west end of the silo tower contains aqueous makeup facilities (AMUs) for the extraction columns. These facilities occupy five levels of the tower and

\section{TABLE 3.23. Principal Contaminants in Column Shaft}

\begin{tabular}{|c|c|c|c|c|c|c|}
\hline \multirow[b]{2}{*}{ Contaminant } & \multirow[b]{2}{*}{ Values } & \multirow[b]{2}{*}{ Units } & \multirow{2}{*}{$\begin{array}{l}\% \text { Total } \\
\text { Facility } \\
\text { Contam. }\end{array}$} & \multicolumn{2}{|c|}{ Activity } & \multirow{2}{*}{$\begin{array}{l}\text { Activity } \\
\text { Survey } \\
\text { Date }\end{array}$} \\
\hline & & & & Level & Unit & \\
\hline \multirow[t]{2}{*}{ Plutonium } & 225 & $\mathrm{Ci}$ & \multicolumn{3}{|c|}{$\begin{array}{l}\text { Assumed to contain }-15 \% \text { of total facil- } \\
\text { ity Pu contamination, } 5 \% \text { of total fission } \\
\text { products }\end{array}$} & 1992 \\
\hline & & & \multicolumn{4}{|c|}{$\begin{array}{l}\text { Assuming this plutonium is of the same isotopic mix } \\
\text { (including } \mathrm{Np} \text { and } \mathrm{Am} \text { ) as in the } 233-\mathrm{S} \text { Building, the } \\
\text { following mix is imputed: }\end{array}$} \\
\hline Pu-239 & 730.6 & g & 80 est & 45.3 & $\mathrm{Ci}$ & \\
\hline Pu-240 & 46.9 & g & 80 est & 10.7 & $\mathrm{Ci}$ & \\
\hline $\mathrm{Pu}-241$ & 1.56 & g & 80 est & 161 & $\mathrm{Ci}$ & \\
\hline Am-241 & 2.34 & g & 80 est & 8 & $\mathrm{Ci}$ & \\
\hline $\mathrm{Np}-237$ & 1.63 & g & 80 est & 1.2 & $\mathrm{mCi}$ & \\
\hline Beta emitters ${ }^{(a)}$ & 450 & $\mathrm{Ci}$ & 85 est & 450 & $\mathrm{Ci}$ & 1992 \\
\hline Asbestos & Unk. & Unk. & \multicolumn{4}{|c|}{$\begin{array}{l}\text { Asbestos can be expected to be found on steam piping, } \\
\text { and may have been used elsewhere in this subfacility. } \\
\text { Any asbestos within the column shaft will be con- } \\
\text { taminated and will be removed with the contaminated } \\
\text { equipment. }\end{array}$} \\
\hline $\begin{array}{l}\text { (a) The beta } \\
\text { fuel at the }\end{array}$ & $\begin{array}{l}\text { ters are } \\
e \text { of re }\end{array}$ & $\begin{array}{l}\text { umed } \\
\text { essing }\end{array}$ & represent the & s of the & n prod & in the \\
\hline
\end{tabular}


consist of various mixing tanks for adjusting the chemistry of the makeup feed and pumps for introducing the additives as feed.

The five levels of makeup facilities extend to the top of the column shaft. The west part of the silo crane gallery is directly above the fifth makeup level. Above this gallery is a floor divided into a column operating room and a column sampling room. The eighth floor of the tower holds the feed tank room, which contains feed tanks for the extraction column. An air conditioning blower is located in another room on this floor.

Table 3.24 summarizes the description of this subfacility.

\section{Description of Contamination}

The entire west end of the tower, containing the noted equipment, was basically a "clean" area during operation. Currently, this area is open to maintenance personnel and is monitored frequently for radiation. The surveys indicate sporadic small areas of low-level radiation, typically beta or beta-gamma radiation, near penetrations into the tower column shaft. The smearability of these areas appears to be very low.

The roof of the silo contains about $28 \mathrm{~m}^{3}$ of asbestos-containing roofing compound, applied in a $75-\mathrm{mm}$ layer.

Table 3.25 describes the contamination status of this subfacility. 
TABLE 3.24. Physical Description of the Tower Column Makeup and Operating Facilities

\begin{tabular}{||l|c|c||}
\hline \multicolumn{1}{|c|}{ Description/Dimensions } & Values & Units \\
\hline \hline Makeup levels & & \\
\hline Number of levels & 5 & $\mathrm{~m}$ \\
\hline Maximum height & 25.56 & $\mathrm{~m}$ \\
\hline Maximum height above grade & 21.06 & $\mathrm{~m}$ \\
\hline Maximum depth below grade & 4.50 & $\mathrm{~m}$ \\
\hline Total floor area & 635.69 & $\mathrm{~m}^{2}$ \\
\hline Total interior volume & $3,132.42$ & $\mathrm{~m}^{3}$ \\
\hline Total concrete volume & $1,034.73$ & $\mathrm{~m}^{3}$ \\
\hline Control and sample rooms and feed tank level & & \\
\hline Maximum height & 9.1 & $\mathrm{~m}$ \\
\hline Max. height above grade & 35.69 & $\mathrm{~m}$ \\
\hline Total floor area & 503 & $\mathrm{~m}^{2}$ \\
\hline Total interior volume & $2,193.71$ & $\mathrm{~m}^{3}$ \\
\hline Total concrete volume & 968.39 & $\mathrm{~m}^{3}$ \\
\hline Total asbestos compound volume & 20.8 & $\mathrm{~m}^{3}$ \\
\hline Total subfacility & $2,138.4$ & $\mathrm{~m}^{2}$ \\
\hline Total floor area & $5,326.1$ & $\mathrm{~m}^{3}$ \\
\hline Total interior volume & $2,003.12$ & $\mathrm{~m}^{3}$ \\
\hline Total concrete volume & 20.8 & $\mathrm{~m}^{3}$ \\
\hline Total asbestos compound volume & & \\
\hline
\end{tabular}


TABLE 3.25. Principal Contaminants in Tower Column

Makeup and Operating Facilities

\begin{tabular}{|l|l|l|}
\hline \multicolumn{1}{|c|}{ Contaminant } & & \multicolumn{1}{|c|}{ Values } \\
\hline \hline $\begin{array}{l}\text { Radioactive } \\
\text { Contaminants }\end{array}$ & $\begin{array}{l}\text { Surveys reveal isolated spots of low-level beta-gamma } \\
\text { radiation. }\end{array}$ & Units \\
\hline Asbestos & $\begin{array}{l}\text { About } 21 \mathrm{~m}^{3} \text { of asbestos roofing compound, probably } \\
\text { reasonably well fixed. }\end{array}$ & \\
\hline
\end{tabular}

\subsubsection{Canyon East End Facilities}

\section{Physical Description}

At the east end of the canyon is a massive concrete structure that forms the east wall to the process cells. This structure, which reaches from $1 \mathrm{~m}$ above the canyon deck to the building foundations, is $4.6 \mathrm{~m}$ in thickness and extends across the ends of the process cells and the tunnels between them. Within this structure are three vertically-stacked north-south channels. The lowest channel, extending from the air tunnel south, is an extension of the air tunnel by which it leaves the building enroute to the filter house and stack. The upper two channels form passageways between the pipe galleries and sample galleries on the north and south sides of the process cell array.

East of the cross-canyon passageways, a railroad tunnel enters the building from the north, extending along the end wall of the north bank of canyon galleries and for the width of the shielded canyon. The deck slab does not extend over the tunnel (except for a walkway above the north end of the tunnel). Metal plates cover the opening above the tunnel when it is not in use. The deck slab resumes beyond the tunnel and extends to the end of the canyon. 
A concrete slab $1.2 \mathrm{~m}$ thick extends above the north end of the tunnel, from the north canyon wall north along the end of the north gallery structure, acting as a roof for the part of the tunnel outside the canyon. The tunnel is closed at its north end with a rolling steel door.

The rail tunnel was the entry point for spent fuel delivered to the facility for reprocessing. It was also the point at which replacement processing equipment for use in the canyons entered the building and from which replaced equipment was shipped for disposal.

Directly to the east of the rail tunnel, beneath the end of the canyon deck, is a shielded remote shop. The deck above the remote shop is fitted with concrete shield plugs. This shop was used for maintenance and repair of highly contaminated process equipment and for preparing replaced equipment for shipment.

The shop extends the width of the shielded canyon and eastward $4.6 \mathrm{~m}$ to the east shield wall of the canyon. The shield wall extends to about $5.4 \mathrm{~m}$ above the floor of the remote shop; it is supported by concrete columns placed at the east end of the shop. The east wall of the remote shop is formed by steel plates extending along the column line between the walls of the shielded canyon.

East of the remote shop is a decontamination room, for decontaminating equipment and materials to be removed from the building or for entry into the regulated shop. This shop is south of the remote shop and decontamination room, east of the cross-canyon passageways, and in line with the south galleries. A monorail crane runs from the remote shop through the decontamination room and into the regulated shop.

Above the decontamination room and regulated shop, with floors at building grade elevation, are three rooms providing building entry: an SWP change 
room, an SWP lobby, and a store room for health physics equipment. An airlock from outside the building enters the change area. These rooms use the space above the shop area and under the canyon crane maintenance area. A stairwell rises from the ground floor to the crane maintenance platform.

Table 3.26 contains a summary description of the east end facilities.

\section{Description of Contamination}

The rail tunnel was used in the transportation of radioactive materials and was subject to contamination. However, as an interface to the outside environment, it was routinely decontaminated following shipments, and it was given a final decontamination following closure of the facility. Some contamination, however, remains along and under the rails.

The remote shop was used in handling pieces of equipment which may have been highly contaminated; the floor of the shop was partially decontaminated when the facility was shut down, but moderate contamination levels remain. The entire area of the remote shop, decontamination room, and regulated shop will likely require removal of the surface concrete containing the contamination.

The SWP change room and lobby were initially maintained as "clean" areas; there are indications, however, that some low-level contamination exists in the change room. The health physics storage room, which is serving as a storage room for some contaminated equipment, may have become contaminated from the stored material.

Estimated contamination in the east end facilities is shown in Table 3.27. 
TABLE 3.26. Physical Description of the East End Facilities

\begin{tabular}{||l|r|c||}
\hline \multicolumn{1}{|c|}{ Description/Dimensions } & \multicolumn{1}{c|}{ Values } & Units \\
\hline \hline Railroad tunnel & & \\
\hline Maximum height & 7.15 & $\mathrm{~m}$ \\
\hline Maximum height above grade & 2.9 & $\mathrm{~m}$ \\
\hline Maximum depth below grade & 4.8 & $\mathrm{~m}$ \\
\hline Total floor area & 191.75 & $\mathrm{~m}^{2}$ \\
\hline Total interior volume & 685.07 & $\mathrm{~m}^{3}$ \\
\hline Total concrete volume & 651.46 & $\mathrm{~m}^{3}$ \\
\hline Shop areas & & \\
\hline Maximum height & 9.1 & $\mathrm{~m}$ \\
\hline Max height above grade & 5.5 & $\mathrm{~m}$ \\
\hline Total floor area & 219.08 & $\mathrm{~m}^{2}$ \\
\hline Total interior volume & $1,439.60$ & $\mathrm{~m}^{3}$ \\
\hline Total concrete volume & 138.96 & $\mathrm{~m}^{3}$ \\
\hline Health physics facilities & & \\
\hline Maximum height & 8.2 & $\mathrm{~m}$ \\
\hline Max height above grade & 8.2 & $\mathrm{~m}$ \\
\hline Total floor area & 157.69 & $\mathrm{~m}^{2}$ \\
\hline Total interior volume & $1,297.72$ & $\mathrm{~m}^{3}$ \\
\hline Total concrete volume & 48.06 & $\mathrm{~m}^{3}$ \\
\hline Total subfacility & 3.442 .38 & $\mathrm{~m}^{3}$ \\
\hline Total floor area & 838.47 & $\mathrm{~m}^{3}$ \\
\hline Total interior volume & $\mathrm{m}^{3}$ \\
\hline Total concrete volume & & \\
\hline Total asbestos compound volume & & \\
\hline \hline
\end{tabular}


TABLE 3.27. Principal Contaminants in East End Facilities

\begin{tabular}{|l|l|l||}
\hline \multicolumn{1}{|c|}{ Contaminant } & \multicolumn{1}{|c||}{ Values } & Units \\
\hline $\begin{array}{l}\text { Radioactive } \\
\text { Contamination }\end{array}$ & $\begin{array}{l}\text { Possible moderate to heavy, non-smearable contamination } \\
\text { in remote shop; light to moderate in decontamination area, } \\
\text { regulated shop. Some light, non-smearable contamination } \\
\text { on tunnel floor. HP area basically clean. }\end{array}$ & \\
\hline Asbestos & About $4 \mathrm{~m}^{3}$ roofing compound on tunnel roof. & \\
\hline
\end{tabular}

\subsubsection{Service Wings}

\section{Physical Description}

The building contains three service wings, along the north, south and west sides of the canyon building. The south and west wings join to make an ell-shaped structure one to two stories ( 3.6 to $8.3 \mathrm{~m}$ ) above ground floor level.

The north wing contains an air conditioning blower, electrical switchgear rooms, and a battery room. Two subgrade rooms are designated for routing electrical cables. The west and south wings contain primarily offices and shops; the west wing also contains a chemical storage area, and the south wing holds three air conditioning blowers, a compressor room, and a room for ozone-generating equipment. Another cable room is located below grade under the south wing.

The wings are built to light industrial standards and would require only razing for their demolishment. The three cable rooms may contain some low-level contamination from diffusion from the canyon cells and galleries, but the wings appear to be otherwise essentially free of contamination. 


\subsection{Plutonium Production Reactor}

\section{Overview of Facility}

The representative reactor facility, similar to those constructed on the Hanford site, is a graphite-moderated, water-cooled nuclear reactor constructed to produce plutonium for the national defense program (Miller and Steffes 1986; DOE 1989). This reactor featured once-through cooling, where the effluent water discharged from the reactor was returned to the same river from which the original source of cooling water for the reactor was obtained. Aluminum process tubes extending through the reactor structure carried the cooling water and aluminum-clad uranium fuel elements.

This reactor facility was built and placed into operation in the mid-1940s and was retired in the mid-1960s. The primary sources of contamination remaining within the reactor are located within the graphite reactor block and within the spent fuel storage basin. The reactor building is $76 \mathrm{~m}$ in length and $70 \mathrm{~m}$ in width, with a height of $29 \mathrm{~m}$. The floor area (footprint) of the building is $5,073 \mathrm{~m}^{2}$. The building grade is $125.7 \mathrm{~m}$ above $\mathrm{msl}$, or about $7 \mathrm{~m}$ above the 500-year Standard Project Flood.

For purposes of this description, the building is described in terms of ten subfacilities differing in construction, operational use, or levels/types of contamination. These subfacilities are the following:

- The graphite stack, or core of the reactor

- The thermal shield for the reactor 
- The process tubes that held the fuel assemblies in the reactor and carried cooling water

- The reactor control system

- The reactor biological shield

- The storage basin

- The reactor control room

- Reactor operations support offices

- A machine shop

- An analytical laboratory.

A cutaway view of the reactor building is shown in Figure 3.19, and a similar view detailing the structure of the reactor block is shown in Figure 3.20. The reactor building was constructed without confinement capabilities. Atmospheric balance and directed air flows were relied on for control of airborne contamination; reactor cooling water flow was once-through.

The building is constructed mainly of reinforced, poured concrete and concrete blocks. The reactor structure, referred to as the reactor block, consists of the graphite stack, thermal and biological shields, channels for process tubes and control rods, and a massive concrete base, $2.4 \mathrm{~m}$ thick, underlying the graphite stack and the surrounding thermal shields. This base and the biological shield enclosing the reactor block rest on a foundation block about $4.5 \mathrm{~m}$ in depth and 


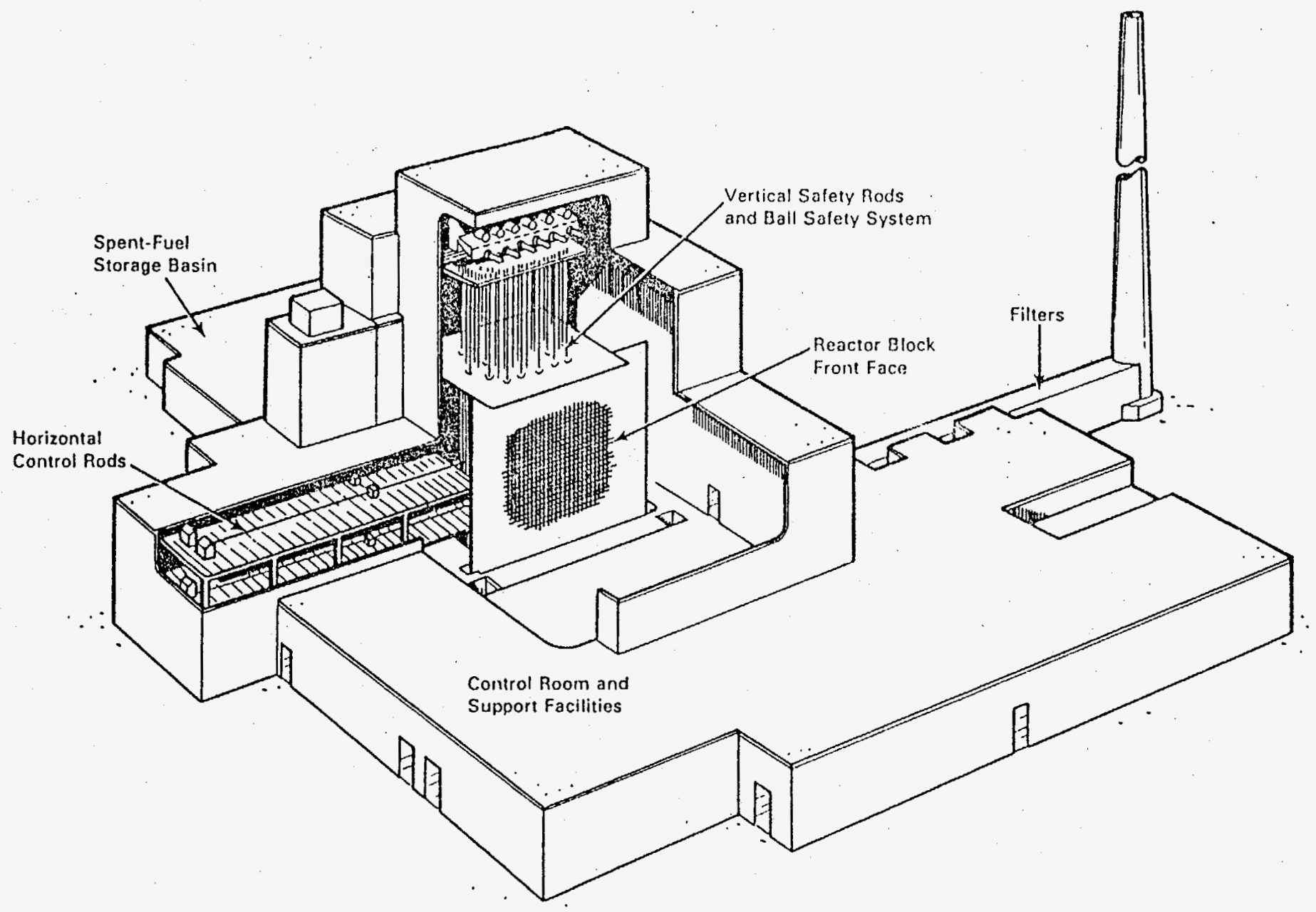

FIGURE 3.19. Cutaway View of Reactor Building 


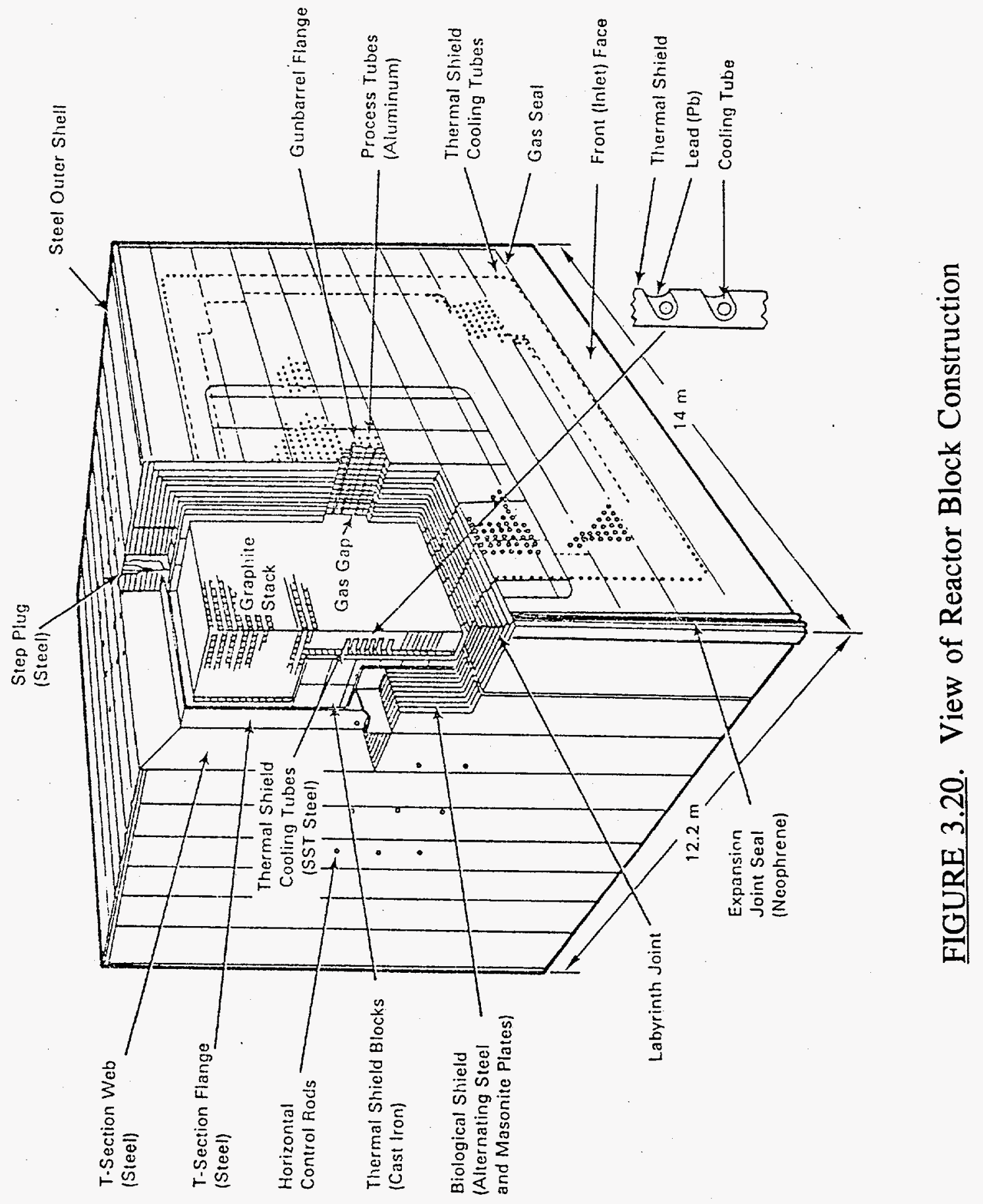


extending to $7 \mathrm{~m}$ beneath ground level. The entire reactor block is surrounded by a $0.635 \mathrm{~cm}(1 / 4$-inch) steel plate and equipped with gas seals at all penetrations to contain the helium-based cover gas of the reactor.

Portions of the building surrounding the reactor block are largely constructed of reinforced concrete, to provide added radiation shielding and provide adequate equipment support. The major concrete structure is a shielding wall, $17.2 \mathrm{~m}$ in height, that surrounds the reactor block and several work areas. The sections composing this wall include

- A 1.5-m-thick concrete shielding wall structure forming an inverted "box" enclosing the rear (discharge) face of the reactor and extending from the reactor foundation to an elevation about $17.2 \mathrm{~m}$ above grade elevation ( $4.2 \mathrm{~m}$ above the top of the reactor block). The interior of this "box" contains the rear face of the reactor, the discharge elevator and its associated work area, and the discharge pool into which fuel assemblies drop when discharged from the process tubes. Labyrinth entries permit personnel access to the rear face area during reactor shutdown. Extensions from the sides of this "box" form rectangular channels carrying discharge pipe risers and a baffled "downcomer" channel through which the radioactive discharged cooling water flows down to the exit line from the building.

- A continuous, stepped wall, $1 \mathrm{~m}$ thick, extending parallel to the "near" side of the reactor block (the left side as viewed from the front of the reactor) and enclosing one side of the work area at the front face. An extension from this wall provides a shielding wall 
enclosing the inner rod room (containing the radioactive sections of the horizontal control rods) and a 1.2-m-thick ceiling shield for the reactor control room, situated directly under the inner rod room.

- Another continuous, stepped wall, $1 \mathrm{~m}$ thick, on the "far" side of the reactor, enclosing the far side of the reactor block, several experimental areas (the " $\mathrm{X}$ " levels) adjacent to the reactor, and the far side of the front face work area.

- A 1 -m-thick wall approximately $14 \mathrm{~m}$ in front of the reactor front face, closing in the work area and providing, with the "near" side shield wall, a baffled entrance to the work area.

Another major concrete structure is the spent fuel storage pool, which will be described later.

The total volume of reinforced concrete in the building is approximately $8,400 \mathrm{~m}^{3}$.

Other portions of the building are of concrete frame construction with concrete block walls, or steel-framed with concrete block or corrugated asbestos-cement board walls.

A summary description of the reactor building is given in Table 3.28. More detailed descriptions are provided for the subfacilities of this building in later sections. 
TABLE 3.28. Physical Description of the Reactor Building

\begin{tabular}{|c|c|c|}
\hline Description/Dimensions & Values & Units \\
\hline Facility type & Production reactor & \\
\hline Facility description & $\begin{array}{l}\text { Graphite-moderated, water-cooled, } \\
\text { once-through }\end{array}$ & \\
\hline Maximum length & 76 & $\mathrm{~m}$ \\
\hline Maximum width & 70 & $\mathrm{~m}$ \\
\hline Height above grade & 29 & m \\
\hline Depth below grade & 7 & $\mathrm{~m}$ \\
\hline Building footprint at grade & 5,073 & $\mathrm{~m}^{2}$ \\
\hline Building grade rel. to sea level & 125.7 & $\mathrm{~m}$ \\
\hline Grade rel to Standard Project Flood & 7 & $\mathrm{~m}$ \\
\hline Construction type & Reinforced concrete, concrete blocks & \\
\hline Maximum wall thickness & $1.7^{c}$ & $\mathbf{m}$ \\
\hline $\begin{array}{l}\text { Reinforced concrete volume (excluding reactor } \\
\text { base and concrete }>1 \mathrm{~m} \text { below grade) }\end{array}$ & 8,400 & $\mathrm{~m}^{3}$ \\
\hline $\begin{array}{l}\text { Reactor block volume } \\
\text { (excluding base) }\end{array}$ & 2,450 & $\mathrm{~m}^{3}$ \\
\hline Reactor base volume & 2,304 & $\mathrm{~m}^{3}$ \\
\hline Reactor block weight (excluding base) & 7,279 & tonne $(t)$ \\
\hline Reactor base weight & 808 & $\mathrm{t}$ \\
\hline
\end{tabular}

\section{Description of Contamination}

Radioactive contaminants in this facility consist of fission products and transuranic isotopes produced in nuclear fission and released from failed fuel assemblies and products of neutron irradiation of reactor construction materials and cooling water contained in the construction materials or released by corrosion and subsequently deposited as "crud" in the spent fuel storage basin or in water transfer lines. Approximately $15,200 \mathrm{Ci}$ of radioactivity are contained within 
the reactor block; an additional $110 \mathrm{Ci}$ are estimated to be located outside the block, primarily in the spent fuel storage basin. This contamination is estimated to be present in $35.9 \%$ of the total facility surface area. The amount of this contamination that is in a disposable form, as opposed to being fixed to the facility surfaces, is currently unknown.

In addition, substantial quantities of lead were used in the facility, as a construction material in portions of the shields and in shielding applications external to the reactor. About 85 metric tons ( $t$ ) of lead and small quantities of cadmium are estimated to remain in the facility.

A summary of contamination in the reactor building is given in Tables 3.29 and 3.30. More detailed listings are given in descriptions of the sub-facilities in later sections of this report.

The data used for radioactive contamination of the facility are based on estimates made in 1986; many of the radiological surveys were performed in 1985. Since that time, there has been some lowering of total radionuclide content through decay. No credit for this decay was taken in the description.

\section{Environmental Setting}

The environmental setting for this source term description is given in Section 4.3.

\subsubsection{Reactor Graphite Stack}

\section{Physical Description}

The graphite core of the reactor constituted the neutron moderator for the reactor and also provided physical support for the reactor process tubes, control 
TABLE 3.29. Total Content of Radionuclides in the Reactor Building

\begin{tabular}{||l|r|c|c|c||}
\hline \multicolumn{5}{|c|}{ Radioactive Contaminants } \\
\hline \hline Radionuclide & Values & Units & $\begin{array}{c}\text { \% Total } \\
\text { Facility } \\
\text { Contam. }\end{array}$ & $\begin{array}{c}\text { Activity } \\
\text { Survey } \\
\text { Date }\end{array}$ \\
\hline \hline Tritium (H) & 5,500 & $\mathrm{Ci}$ & 35.9 & $3-1-85$ \\
\hline Carbon-14 & 3,500 & $\mathrm{Ci}$ & 22.8 & $3-1-85$ \\
\hline Calcium-41 & 56 & $\mathrm{Ci}$ & 0.4 & $3-1-85$ \\
\hline Cobalt-60 & 5,241 & $\mathrm{Ci}$ & 34.2 & $3-1-85$ \\
\hline Nickel-59 & 7.6 & $\mathrm{Ci}$ & $<0.1$ & $3-1-85$ \\
\hline Nickel-63 & 871 & $\mathrm{Ci}$ & 5.7 & $3-1-85$ \\
\hline Chlorine-36 & 17 & $\mathrm{Ci}$ & 0.1 & $3-1-85$ \\
\hline Strontium-90 & 24.2 & $\mathrm{Ci}$ & 0.2 & $3-1-85$ \\
\hline Cesium-137 & 47 & $\mathrm{Ci}$ & 0.3 & $3-1-85$ \\
\hline Europium-152 & 43 & $\mathrm{Ci}$ & 0.3 & $3-1-85$ \\
\hline Europium-154 & 25.3 & $\mathrm{Ci}$ & 0.2 & $3-1-85$ \\
\hline & & & & \\
\hline Plutonium-238 & 0.1 & $\mathrm{Ci}$ & $<0.1$ & $3-1-85$ \\
\hline Plutonium-239 & 2.6 & $\mathrm{Ci}$ & $<0.1$ & $3-1-85$ \\
\hline Americium-241 & 0.8 & $\mathrm{Ci}$ & $<0.1$ & $3-1-85$ \\
\hline TOTAL & $15,335.6$ & $\mathrm{Ci}$ & & $3-1-85$ \\
\hline
\end{tabular}

TABLE 3.30. Total Content of Chemical Contaminants

\begin{tabular}{||l|c|c|c||}
\hline \multicolumn{4}{|c|}{ Chemical/Mixed Contaminants } \\
\hline \hline \multicolumn{1}{|c|}{ Component } & Values & Units & $\begin{array}{c}\text { \% Total } \\
\text { Facility } \\
\text { Contam. }\end{array}$ \\
\hline \hline Irradiated Lead & 72.6 & $\mathrm{t}$ & 85.2 \\
\hline Nonirradiated Lead & 12.6 & $\mathrm{t}$ & 14.8 \\
\hline Cadmium & 13.6 & $\mathrm{~kg}$ & $<0.1$ \\
\hline TOTAL & 85.2 & $\mathrm{t}$ & \\
\hline
\end{tabular}


rods, the top shield, and other reactor components. The stack is composed of a large number of machined, hand-laid, keyed blocks of high-purity graphite. The primary blocks are each $10.6 \mathrm{~cm}$ square and $121.9 \mathrm{~cm}$ in length, machined to fit closely and locked in place by thin graphite keys. The blocks were laid in alternating layers, one layer running from front to rear and the next side to side. Designated blocks contain machined channels to accommodate the reactor process tubes (front to rear), control rods (side to side), and the vertical safety rods (VSRs) (top to bottom). The graphite was permeated by a reactor cover gas. Initially this gas was helium; in later years of operation, gas mixtures containing helium were used to provide finer control of graphite temperatures.

Dimensions and weight of the graphite block are shown in Table 3.31.

\section{Description of Contamination}

The graphite in the reactor was fully exposed to the reactor neutron flux, which resulted in formation of comparably large quantities of carbon-14, from the graphite itself, and also of tritium $\left({ }^{3} \mathrm{H}\right)$. The tritium in the graphite is generated primarily from neutron reaction with nitrogen-14, which is present as an impurity in the graphite and also as a component of the reactor cover gas. To a lesser extent, it is formed by neutron activation of deuterium in transient water within the stack. In addition, occasional ruptures of process tubes occurred during operation. Water, with any chemicals it held, entered the stack by this means. Also, if the ruptured tube contained failed fuel assemblies, both transuranic isotopes and fission products could enter the stack. Any nuclides entering the stack area would likely remain there until they decayed.

The principal contaminant species and their levels within the graphite stack are summarized in Table 3.32 . 
TABLE 3.31. Description of the Reactor Graphite Stack

\begin{tabular}{|l|c|c|}
\hline \multicolumn{1}{|c|}{ Description/Dimensions } & Values & Units \\
\hline \hline Length (front-rear) & 8.5 & $\mathrm{~m}$ \\
\hline Width (side-side) & 11 & $\mathrm{~m}$ \\
\hline Height & 11 & $\mathrm{~m}$ \\
\hline Horizontal Area & 93.5 & $\mathrm{~m}^{2}$ \\
\hline Weight & 1,636 & $\mathrm{t}$ \\
\hline Construction materials & \multicolumn{2}{|c|}{ Stacked carbon blocks } \\
\hline
\end{tabular}

TABLE 3.32. Principal Contaminants in Graphite Stack

\begin{tabular}{|l|c|c|c|c||}
\hline \multicolumn{5}{|c|}{ Radioactive Contaminants } \\
\hline \hline Radionuclide & Values & Units & $\begin{array}{c}\text { \% Total } \\
\text { Facility } \\
\text { Contam. }\end{array}$ & $\begin{array}{c}\text { Activity } \\
\text { Survey } \\
\text { Date }\end{array}$ \\
\hline \hline Tritium ( $\left.{ }^{3} \mathrm{H}\right)$ & 5,500 & $\mathrm{Ci}$ & 100 & $3-1-85$ \\
\hline Carbon-14 & 3,500 & $\mathrm{Ci}$ & 100 & $3-1-85$ \\
\hline Calcium-41 & 54 & $\mathrm{Ci}$ & 96.4 & $3-1-85$ \\
\hline Cobalt-60 & 40 & $\mathrm{Ci}$ & 0.8 & $3-1-85$ \\
\hline Nickel-59 & 1 & $\mathrm{Ci}$ & 13.1 & $3-1-85$ \\
\hline Nickel-63 & 120 & $\mathrm{Ci}$ & 13.8 & $3-1-85$ \\
\hline Chlorine-36 & 17 & $\mathrm{Ci}$ & 100 & $3-1-85$ \\
\hline Strontium-90 & 10 & $\mathrm{Ci}$ & 41.3 & $3-1-85$ \\
\hline Cesium-137 & 30 & $\mathrm{Ci}$ & 63.8 & $3-1-85$ \\
\hline Europium-152 & 40 & $\mathrm{Ci}$ & 93 & $3-1-85$ \\
\hline Europium-154 & 20 & $\mathrm{Ci}$ & 79.1 & $3-1-85$ \\
\hline Plutonium-239 & 1 & $\mathrm{Ci}$ & 38.5 & $3-1-85$ \\
\hline Americium-241 & 0.3 & $\mathrm{Ci}$ & 37.5 & $3-1-85$ \\
\hline \hline
\end{tabular}




\subsubsection{Reactor Thermal Shield}

\section{Physical Description}

The reactor thermal shield surrounds the graphite reactor core and absorbs radiation, principally gamma rays, and a portion of the neutrons streaming from the reactor core. The thermal shield converts the impacted radiation to heat, lowering radiation levels outside its boundaries and protecting the outer biological shield from excess heating.

The thermal shield, from 20 to $26 \mathrm{~cm}$ thick, completely surrounds the graphite stack. The shield is composed of approximately 3,300 cast-iron blocks arranged in a continuous, single layer on all six sides of the stack. The bottom shield layer rests directly on the concrete reactor base; the shield on the top and sides of the stack is a continuous layer of blocks between the stack and the biological shield. On the front and rear faces of the reactor, designated blocks have holes to allow passage of the process tubes. Similar holes in blocks on the top and sides of the stack allow entry of control rods, VSRs, and experimental channels.

The top, bottom, and side thermal shields are water-cooled; stainless steel cooling tubes were fitted into slots in blocks in these locations and secured by filling the slots with poured lead.

A summary of the dimensions and weight of the thermal shield is given in Table 3.33. 
TABLE 3.33. Description of Reactor Thermal Shield

\begin{tabular}{|l|l|l||}
\hline \multicolumn{1}{|c|}{ Description/Dimension } & \multicolumn{1}{|c|}{ Values } & Units \\
\hline \hline Shield coverage & All six faces of stack & \\
\hline Shield materials & Cast iron blocks & \\
\hline Number of blocks & 3,300 & \\
\hline Water-cooled blocks & Top, bottom, left, and right side blocks & \\
\hline Water cooling means & Stainless steel water tubes (except front, rear shields) & \\
\hline Means of securing cooling tubes & Slots in blocks, tubes held by poured lead & \\
\hline Weight of shield blocks & 1,019 & $t$ \\
\hline
\end{tabular}

\section{Description of Contamination}

Radioactive contamination in the thermal shield results primarily from neutron activation of constituents of the cast-iron blocks. The lead used to secure cooling lines to the shield blocks has been irradiated in place, adding to the overall radioactive burden as well as to the hazardous nature of the lead itself.

Since the cooling tubes were stainless steel, they added disproportionately to the burden of nickel-59 and nickel-63 isotopes, although their contribution to the cobalt -60 content of the shield was minor.

The contaminants and the levels of contamination in the thermal shield are shown in Table 3.34. 
TABLE 3.34. Principal Contaminants in Thermal Shield

\begin{tabular}{||l|r|r|r|r|r|r||}
\hline \multicolumn{7}{|c|}{ Radioactive Contaminants } \\
\hline \hline \multicolumn{1}{|c|}{ Radionuclide } & Values & Units & $\begin{array}{c}\text { F Total } \\
\text { Contam. }\end{array}$ & \multicolumn{2}{|c|}{ Activity } & $\begin{array}{c}\text { Activity } \\
\text { Survey } \\
\text { Date }\end{array}$ \\
\hline \hline Shield Blocks & & & & & & \\
\hline \hline Cobalt-60 & 4,800 & $\mathrm{Ci}$ & $\mathrm{U}^{\text {(a) }}$ & & & $3-1-85$ \\
\hline Nickel-59 & 2 & $\mathrm{Ci}$ & $\mathrm{U}$ & & & $3-1-85$ \\
\hline Nickel-63 & 310 & $\mathrm{Ci}$ & $\mathrm{U}$ & & & $3-1-85$ \\
\hline \hline Cooling Tubes & & & & & & \\
\hline \hline Cobalt-60 & 70 & $\mathrm{Ci}$ & $\mathrm{U}$ & & & $3-1-85$ \\
\hline Nickel-59 & 4 & $\mathrm{Ci}$ & $\mathrm{U}$ & & & $3-1-85$ \\
\hline Nickel-63 & 370 & $\mathrm{Ci}$ & $\mathrm{U}$ & & & $3-1-85$ \\
\hline \hline Total System & & & & & & \\
\hline Cobalt-60 & 4,870 & $\mathrm{Ci}$ & 92.9 & & & $3-1-85$ \\
\hline Nickel-59 & 6 & $\mathrm{Ci}$ & 78.8 & & & $3-1-85$ \\
\hline Nickel-63 & 680 & $\mathrm{Ci}$ & 78.1 & & & $3-1-85$ \\
\hline (a) Unknown & & & & & & \\
\hline
\end{tabular}

\subsubsection{Reactor Biological Shield}

\section{Physical Description}

The biological shield surrounds the reactor thermal shield on the top and four sides of the reactor. It is designed to attenuate neutrons and gamma radiation passing through the thermal shield to levels commensurate with habitable working locations (concrete walls on the sides of the reactor provide additional shielding to further reduce radiation). This shield, $132 \mathrm{~cm}$ in thickness, is a composite of laminated, alternating sheets of steel and masonite, bound together on steel-plate, T-section flanges whose bases form the inner wall of the shield. 
On the top and sides of the reactor the flanges, welded in place, form cells that are filled with alternating layers of steel and masonite to form the laminated shield. On the front and rear faces of the reactor, the biological shield is composed of sectioned steel blocks containing the laminated steel and masonite filling. These blocks are welded together to form the composite shields on those faces; 69 blocks on each face contain fittings for process tube support sleeves, or "gunbarrels" (2004 gunbarrels in all on each face). Other shield openings are provided on the "near" side of the reactor (the left side as viewed from the front face) to accommodate the horizontal control rods; on the "far" side for experimental penetrations; and on top for the VSRs. Additional penetrations are provided for cooling lines for the shields. The four sides of the shield are welded together; the top shield was placed on top of the sides with labyrinthstepped joints to prevent streaming of radiation through the joints. The top shield was not welded to the side shields.

The entire biological shield is covered by a steel plate $0.635 \mathrm{~cm}$ in thickness, which is welded to a similar plate passing under the reactor base and fitted with gas seals at all openings. This plate provides containment for the reactor cover gas.

A summary of dimensions of the biological shield is given in Table 3.35.

\section{Description of Contamination}

The primary contaminant in the biological shield is calcium-41, formed from neutron activation of calcium in the upper portions of the concrete reactor base. No significant activation of components of the masonite appears to have occurred. The bases of the steel T-flanges contain some activated contaminants; 
TABLE 3.35. Description of the Biological Shield

\begin{tabular}{|l|l|c|}
\hline \multicolumn{1}{|c|}{ Description/Dimensions } & \multicolumn{1}{c|}{ Values } & Units \\
\hline \hline Shield location & Outside thermal shield & \\
\hline Extent of shield coverage & Four sides and top of reactor & \\
\hline Shield thickness & 132 & $\mathrm{~cm}$ \\
\hline Base of shield & Steel T-flanges against thermal shield & \\
\hline Body of shield & $\begin{array}{l}\text { Laminated layers of steel and masonite } \\
\text { between flanges }\end{array}$ & \\
\hline Side and top shield construction & Continuous layer of filled flanges & \\
\hline Front and rear shield construction & $\begin{array}{l}\text { Sectioned composite blocks containing proc- } \\
\text { ess tube openings and gunbarrel supports }\end{array}$ & \\
\hline Outer shield surface & Steel plate (cover gas seal) & \\
\hline Outer plate thickness & 0.635 & $\mathrm{~cm}$ \\
\hline Overall shield height & 14 & $\mathrm{~m}$ \\
\hline Overall shield width & 14 & $\mathrm{~m}$ \\
\hline Overall shield depth (front-rear) & 12.2 & $\mathrm{~m}$ \\
\hline Weight, top and side shields & $2,454.6$ & $\mathrm{t}$ \\
\hline Weight, front and rear shields & $2,002.6$ & $\mathrm{t}$ \\
\hline \hline
\end{tabular}

however, this is substantially lower than contamination in the thermal shield due to neutron attenuation. Steel activation in the biological shield is considered insignificant in reviews of the reactors.

Contamination in the biological shield is summarized in Table 3.36.

\subsubsection{Reactor Process Tubes}

\section{Physical Description}

The aluminum-clad uranium fuel assemblies irradiated in the reactor were held in 2,004 aluminum process tubes extending from the front face to the rear face 
TABLE 3.36. - Principal Contaminants in Biological Shield

\begin{tabular}{||c|c|c|c|c||}
\hline \multicolumn{5}{|c|}{ Radioactive Contaminants } \\
\hline \hline & & & $\begin{array}{c}\% \text { Total } \\
\text { Racility } \\
\text { Radionuclide }\end{array}$ & $\begin{array}{c}\text { Activity } \\
\text { Survey } \\
\text { Date }\end{array}$ \\
\hline \hline Calcium-41 & 2 & $\mathrm{Ci}$ & 96.4 & $3-1-85$ \\
\hline
\end{tabular}

of the reactor. These tubes were fabricated from Type 1100 aluminum alloy, containing a minimum of $99 \%$ aluminum and with maximum impurity levels limited by specifications for those impurities likely to produce long-lived activation products. The process tubes run from the front to the rear of the reactor block through channels drilled in graphite blocks and are arrayed in a square lattice formation centered on the front face of the reactor. In passing through the reactor shields they are contained within supporting gunbarrels, mild steel tubes providing both support for the tubes and seals at the reactor faces. The gunbarrels are considered a part of the process tube assemblies and are responsible for the greater part of the residual contamination reported for these assemblies.

Each process tube is approximately $4.4 \mathrm{~cm}$ in diameter and about $12.5 \mathrm{~m}$ in length. The gunbarrels provide support for the process tubes at the front and rear faces of the reactor block; at each face they extend into the reactor from sealing flanges and gas seals at the face through the shields to mating fittings in the ends of the graphite channel blocks. Several annular cast-iron sections, or 
"doughnuts," serve as radiation baffles in the annuli around the gunbarrels. The doughnut shield pieces are considered part of the biological shield.

Dimensions and characteristics of the process tube assemblies are summarized in Table 3.37.

\section{Description of Contamination}

The process tubes themselves, fabricated from high-purity aluminum, contain minimal residual long-lived activity from neutron activation. The tips of the gunbarrels, exposed directly to the neutron flux within the shields, are activated to the point where the residual cobalt- 60 activity is the predominant contribution to activity of the process tube assembly. Film deposited on the inner surface of

TABLE 3.37. Description of the Process Tube Assemblies

\begin{tabular}{|l|l|c|}
\hline \multicolumn{1}{|c|}{ Description/Dimensions } & \multicolumn{1}{c|}{ Values } & Units \\
\hline \hline Process tube length & Approx. 12.5 & $\mathrm{~m}$ \\
\hline Process tube diameter & 4.4 & $\mathrm{~cm}$ \\
\hline Process tube material & Type 1100 aluminum $(99+\% \mathrm{Al})$ & \\
\hline Number of process tubes & 2,004 & \\
\hline Gunbarrel material & Mild steel & \\
\hline Gunbarrels per tube & 2 (at front and rear faces) & \\
\hline $\begin{array}{l}\text { Process tube assembly weight } \\
\text { (including gunbarrels) }\end{array}$ & 196.8 (all tubes) & $\mathrm{t}$ \\
\hline
\end{tabular}


the process tubes contains precipitates, which resulted from activation of contaminants from corrosion of steel piping and aluminum alloy fuel element cladding, in addition to fission products and actinides released during occasional failure of fuel assemblies within a tube.

Radiological characteristics of the process tube assemblies are summarized in Table 3.38.

\subsubsection{Spent Fuel Storage Pool}

\section{Physical Description}

The spent fuel storage pool is located at the rear of the reactor block, in a single-story concrete-block wing of the reactor building. Beneath the rear face of the reactor is a smaller pool for receiving the spent fuel discharged from the reactor. This pool is separate from the storage pool but is accessible to the working space above the storage pool. A massive shielding wall separates this working area from the rear face area of the reactor and extends down into the

TABLE 3.38. Principal Contaminants in Process Tube Assemblies

\begin{tabular}{||l|c|c|c|c||}
\hline \multirow{4}{*}{ Radionuclide } & Values & Units & $\begin{array}{c}\text { \% Total } \\
\text { Facility } \\
\text { Contam. }\end{array}$ & $\begin{array}{c}\text { Activity } \\
\text { Survey } \\
\text { Date }\end{array}$ \\
\hline \hline Cobalt-60 & 210 & $\mathrm{Ci}$ & 4 & $3-1-85$ \\
\hline Nickel-59 & 0.1 & $\mathrm{Ci}$ & 1.3 & $3-1-85$ \\
\hline Nickel-63 & 10 & $\mathrm{Ci}$ & 1.1 & $3-1-85$ \\
\hline Strontium-90 & 0.2 & $\mathrm{Ci}$ & 0.8 & $3-1-85$ \\
\hline Europium-152 & 1.4 & $\mathrm{Ci}$ & 3.3 & $3-1-85$ \\
\hline Europium-154 & 1.0 & $\mathrm{Ci}$ & 4 & $3-1-85$ \\
\hline
\end{tabular}


discharge pool. The discharge pool has a steeply sloped floor, to cause the discharged assemblies to roll to the accessible area of the pool. From this point, the assemblies were collected into steel transfer buckets and moved to the storage pool, and eventually to an adjacent fuel transfer area for transfer into shielded cask cars and transportation to another site for reprocessing.

The storage pool is about $6 \mathrm{~m}$ deep and has a surface area of about $640 \mathrm{~m}^{2}$. The basin walls average about $0.6 \mathrm{~m}$ thick, and the floor is $0.15 \mathrm{~m}$ thick. Within the pool, a square array of concrete columns rises from the floor to above the surface of the pool. These columns support beams carrying hangers for the metal buckets used for handling fuel.

A summary description of the spent fuel storage pool is given in Table 3.39.

\section{Description of Contamination}

Over its years of operation, about $50,000 \mathrm{~kg}$ of sludge was estimated to have accumulated in the pool, primarily from process tube scale, failed fuel assemblies discharged into the pool, and corrosion products in transient water

TABLE 3.39. Description of the Spent Fuel Storage Pool

\begin{tabular}{|l|l|c|}
\hline \multicolumn{1}{|c|}{ Description/Dimensions } & \multicolumn{1}{|c|}{ Values } & Units \\
\hline \hline Pool surface area & 640 & $\mathrm{~m}^{2}$ \\
\hline Pool depth & 6 & $\mathrm{~m}$ \\
\hline Normal pool contents & $\begin{array}{l}\text { Spent fuel assemblies in transfer buckets; } \\
\text { radioactive components awaiting disposition }\end{array}$ & \\
\hline Estimated sludge contents & 50,000 & $\mathrm{~kg}$ \\
\hline Current pool condition & $\begin{array}{l}\text { Backfilled with earth to pool surface. Sludge, } \\
\text { other components under backfill }\end{array}$ & \\
\hline
\end{tabular}


introduced to the pool during fuel transfer operations. Following permanent shutdown of the reactor, all the fuel contained in the reactor was discharged, and any remaining in the pool was transferred to another site for reprocessing. Subsequently, the pool was emptied to within a few feet of the floor, and a detailed survey of the pool contents was made. Identified objects with high radiation levels were removed for disposal; however, several items, including process tubing, irradiated fuel assembly spacers, miscellaneous reactor hardware, and metal fuel transfer buckets, were left in the pool. Afterward, in 1970 , the pool was backfilled with soil.

There remains the possibility that a few low-exposure fuel elements may still be under the backfill in the reactor pool.

Estimates of contamination in the reactor storage pool are given in Table 3.40.

TABLE 3.40. Principal Contaminants in the Spent Fuel Storage Pool

\begin{tabular}{|c|c|c|c|c|c|c|}
\hline \multicolumn{7}{|c|}{ Radioactive Contaminants } \\
\hline \multirow[b]{2}{*}{ Radionuclide } & \multirow[b]{2}{*}{ Values } & \multirow[b]{2}{*}{ Units } & \multicolumn{2}{|c|}{ Physical Form } & \multirow{2}{*}{$\begin{array}{l}\text { \% Total } \\
\text { Facility } \\
\text { Contam. }\end{array}$} & \multirow{2}{*}{$\begin{array}{l}\text { Activity } \\
\text { Survey } \\
\text { Date }\end{array}$} \\
\hline & & & Fix $\%$ & Disp \% & & \\
\hline Nickel-59 & 0.51 & $\mathrm{Ci}$ & 100 & 0 & 6.7 & $3-1-85$ \\
\hline Nickel-63 & 61 & $\mathrm{Ci}$ & 100 & 0 & 7 & $3-1-85$ \\
\hline Cobalt- 60 & 11 & $\mathrm{Ci}$ & 100 & 0 & 4 & $3-1-85$ \\
\hline Strontium-90 & 14 & $\mathrm{Ci}$ & 100 & 0 & 0.8 & $3-1-85$ \\
\hline Cesium-137 & 17 & $\mathrm{Ci}$ & 100 & 0 & 36.2 & $3-1-85$ \\
\hline Europium-152 & 1.6 & $\mathrm{Ci}$ & 100 & 0 & 3.7 & $3-1-85$ \\
\hline Europium-154 & 4.3 & $\mathrm{Ci}$ & 100 & 0 & 17 & $3-1-85$ \\
\hline Uranium-238 ${ }^{\text {(a) }}$ & 0.009 & $\mathrm{Ci}$ & 100 & 0 & 100 & See note \\
\hline Plutonium-238 ${ }^{(a)}$ & 0.075 & $\mathrm{Ci}$ & $U^{(b)}$ & $\mathrm{U}$ & 100 & See note \\
\hline Plutonium-239 & 1.6 & $\mathrm{Ci}$ & $\mathrm{U}$ & $\mathrm{U}$ & 61.5 & See note \\
\hline Americium-241 ${ }^{\text {(a) }}$ & 0.5 & $\mathrm{Ci}$ & $\mathrm{U}$ & $\mathrm{U}$ & 62.5 & See note \\
\hline \multicolumn{7}{|c|}{$\begin{array}{l}\text { (a) Represents speculative content; allows for possible presence of up to five } \\
\text { spent fuel assemblies. } \\
\text { (b) Unknown. }\end{array}$} \\
\hline
\end{tabular}


It should be emphasized that this estimate is approximate, that the inventory of "tramp" irradiated materials is not known, and that there is a possibility that some fuel assemblies may have been buried beneath the backfill.

\subsubsection{Reactor Control System}

\section{Physical Description}

The reactor control system consists of three major components:

- Reactor control rods, which enter the reactor horizontally through the "near" side of the reactor (the left side as viewed from the frontface of the block) were used for normal control of power level, flux flattening, and suppression of power transients during reactor startup.

- VSRs positioned on top of the reactor top shield and dropped vertically into the graphite core when released manually or automatically. These rods were used for manual or automatic shutdown of the reactor.

- The "ball-3X" system, which was added to all production reactors during the later years of their operation. This system consisted of hoppers filled with small boron-steel balls adjacent to the VSRs. In the event that activation of the VSRs failed to shut the reactor down, the ball hoppers would automatically open, and the balls would roll down the vertical channels in the graphite used by the VSRs. The ball system was never required at any of the reactors; however, periodic testing of the system was required. On occasion, some of the balls would become stuck in the graphite stack and become activated in subsequent operations. 
A description of the reactor safety system is given in Table 3.41 .

\section{Description of Contamination}

The predominant radioactivity induced in any of the safety system components was cobalt- 60 from steel in the rods or balls entering the reactor. The control rods were replaced frequently, thus any one set of rods did not build up high inventories of radioactivity. The safety rods became irradiated on their tips only, since their entry into the reactor stopped the neutron flux. The $3 \mathrm{X}$ balls never entered the reactor during operation; however, during testing, some of the balls became stuck in the graphite stack and were subsequently irradiated.

Analysis of the reactor indicated that the safety system contributed a total of about $100 \mathrm{Ci}$ of cobalt- 60 . The induced activity in the control rods was estimated to be about equivalent to that which would have been produced in the material removed from the thermal shield to provide the holes through which the rods passed.

The contribution of the reactor control system to the inventory of radioactivity is shown in Table 3.42 .

TABLE 3.41. Description of the Reactor Control System

\begin{tabular}{|c|c|c|}
\hline Description/Dimensions & Values & Units \\
\hline Control rods & $\begin{array}{l}\text { Moveable rods entering the reactor horizontally } \\
\text { through the "near" side of the reactor block }\end{array}$ & \\
\hline Safety rods & $\begin{array}{l}\text { "Shut-down" rods moving down into reactor core } \\
\text { when released }\end{array}$ & \\
\hline Ball-3X system & $\begin{array}{l}\text { Safety backup system: hoppers near VSR locations } \\
\text { drop boron-steel balls into safety rod channels if } \\
\text { safety rods fail }\end{array}$ & \\
\hline
\end{tabular}


TABLE 3.42. Principal Contaminants in the Reactor Control System

\begin{tabular}{|c|c|c|c|c|c|c|}
\hline \multicolumn{7}{|c|}{ Radioactive Contaminants } \\
\hline \multirow[b]{2}{*}{ Radionuclide } & \multirow[b]{2}{*}{ Values } & \multirow[b]{2}{*}{ Units } & \multicolumn{2}{|c|}{ Physical Form } & \multirow{2}{*}{$\begin{array}{l}\text { \% Total } \\
\text { Facility } \\
\text { Contam. }\end{array}$} & \multirow{2}{*}{$\begin{array}{c}\text { Activity } \\
\text { Survey } \\
\text { Date }\end{array}$} \\
\hline & & & Fix \% & Disp \% & & \\
\hline Cobalt -60 & 110 & $\mathrm{Ci}$ & 100 & 0 & 2.1 & $3-1-85$ \\
\hline
\end{tabular}

\subsubsection{Other Sub-Facilities in the Reactor}

Four of the identified sub-facilities (the reactor control room, machine shop, analytical laboratory, and an office wing) have no recorded radioactive contamination. Some of these areas may have minor contamination, but no significant sources are on record.

It has been estimated that the recorded radioactivity inventories constitute roughly $95 \%$ of the total radioactivity in the reactor building. The remaining $5 \%$ is postulated to be contained in reactor piping, tunnels within the building, the HVAC system and exhaust filters, and potential but unknown sources in the earth-filled spent fuel storage pool. Thorough radiation surveys of the building have not indicated any significant radiation beyond those sources noted.

\subsubsection{Hazardous and Mixed Waste Materials}

Surveys of the reactor in 1985 and 1986 indicated the presence of nonradioactive hazardous materials, mainly lead and cadmium, but also friable asbestos, mercury, polychlorinated biphenyls (PCBs), and some solvents. The asbestos, mercury, PCBs, and similar materials are being removed under other remediation programs. The primary hazardous materials of concern are the quantities of irradiated and unirradiated lead and unirradiated cadmium stored in various 
locations in the reactor building. These total about $72.6 \mathrm{t}$ of irradiated lead (primarily in the thermal shield as noted earlier); $12.6 \mathrm{t}$ of unirradiated lead, and $13.6 \mathrm{~kg}(0.014 \mathrm{t})$ of cadmium sheets and shaped pieces.

The inventory and locations of lead and cadmium in the reactor building are summarized in Table 3.43; total contaminant levels are indicated in Table 3.44.

TABLE 3.43. Lead and Cadmium Located in Reactor Building

\begin{tabular}{||l|c|c||}
\hline \multicolumn{1}{|c|}{ Description/Location } & Values & Units \\
\hline \hline Experimental Levels & & \\
\hline Unirradiated Lead & 1.46 & $\mathrm{t}$ \\
\hline Cadmium & 13.61 & $\mathrm{~kg}$ \\
\hline Tip of Reactor & & \\
\hline Unirradiated Lead & 7.71 & $\mathrm{t}$ \\
\hline Sample Rooms & & \\
\hline Unirradiated Lead & 2.27 & $\mathrm{t}$ \\
\hline Rod Rooms and Lower Levels & & \\
\hline Unirradiated Lead & 1.15 & $\mathrm{t}$ \\
\hline Reactor Front Face Area & & \\
\hline Unirradiated Lead & 0.011 & $\mathrm{t}$ \\
\hline Reactor Thermal Shield & & \\
\hline Irradiated Lead & 72.6 & $\mathrm{t}$ \\
\hline \hline
\end{tabular}


TABLE 3.44. Lead and Cadmium in Reactor Building

\begin{tabular}{|c|c|c|c|c|c|c|}
\hline \multicolumn{7}{|c|}{ Radioactive and Chemical Contaminants } \\
\hline \multirow[b]{2}{*}{ Contaminant } & \multirow[b]{2}{*}{ Values } & \multirow[b]{2}{*}{ Units } & \multicolumn{2}{|c|}{ Physical Form } & \multirow{2}{*}{$\begin{array}{l}\text { \% Total } \\
\text { Facility } \\
\text { Contam. }\end{array}$} & \multirow{2}{*}{$\begin{array}{c}\text { Activity } \\
\text { Survey } \\
\text { Date }\end{array}$} \\
\hline & & & Fix \% & Disp \% & & \\
\hline Irradiated lead & 72.6 & $t$ & 100 & 0 & 100 & $10-08-85$ \\
\hline Unirradiated lead & 12.6 & $\mathrm{t}$ & 100 & 0 & 100 & $10-08-85$ \\
\hline Cadmium & 13.6 & kg & 100 & 0 & 100 & $10-08-85$ \\
\hline
\end{tabular}

\subsection{Concrete Holding Pond}

\section{Overview of Site}

The representative above-ground liquid storage basin is a concrete-lined radioactive liquid waste holding pond ("hot pond"), similar to a basin located at the Inhalation Toxicology Research Institute (ITRI), that received Class B low-level liquid radioactive wastes and other hazardous substances from 1963 to 1986 (ITRI 1992 and DOE 1988a). This waste was made up of rinsate from radioactively contaminated equipment, samples, gloves, gauze, and other miscellaneous laboratory waste. No effluent has been routed to the pond since 1986 . Figure 3.21 presents a schematic of the pond and the surrounding area.

\section{Physical Description}

The 68,130-L South Pond, which is the particular subject of interest in this source term description, is constructed of concrete and topped with a polyethylene liner. The thickness of the concrete varies from 5.1 to $10.2 \mathrm{~cm}$. In 1990 , the partially disintegrated polyethylene liner and the residual sludge was 


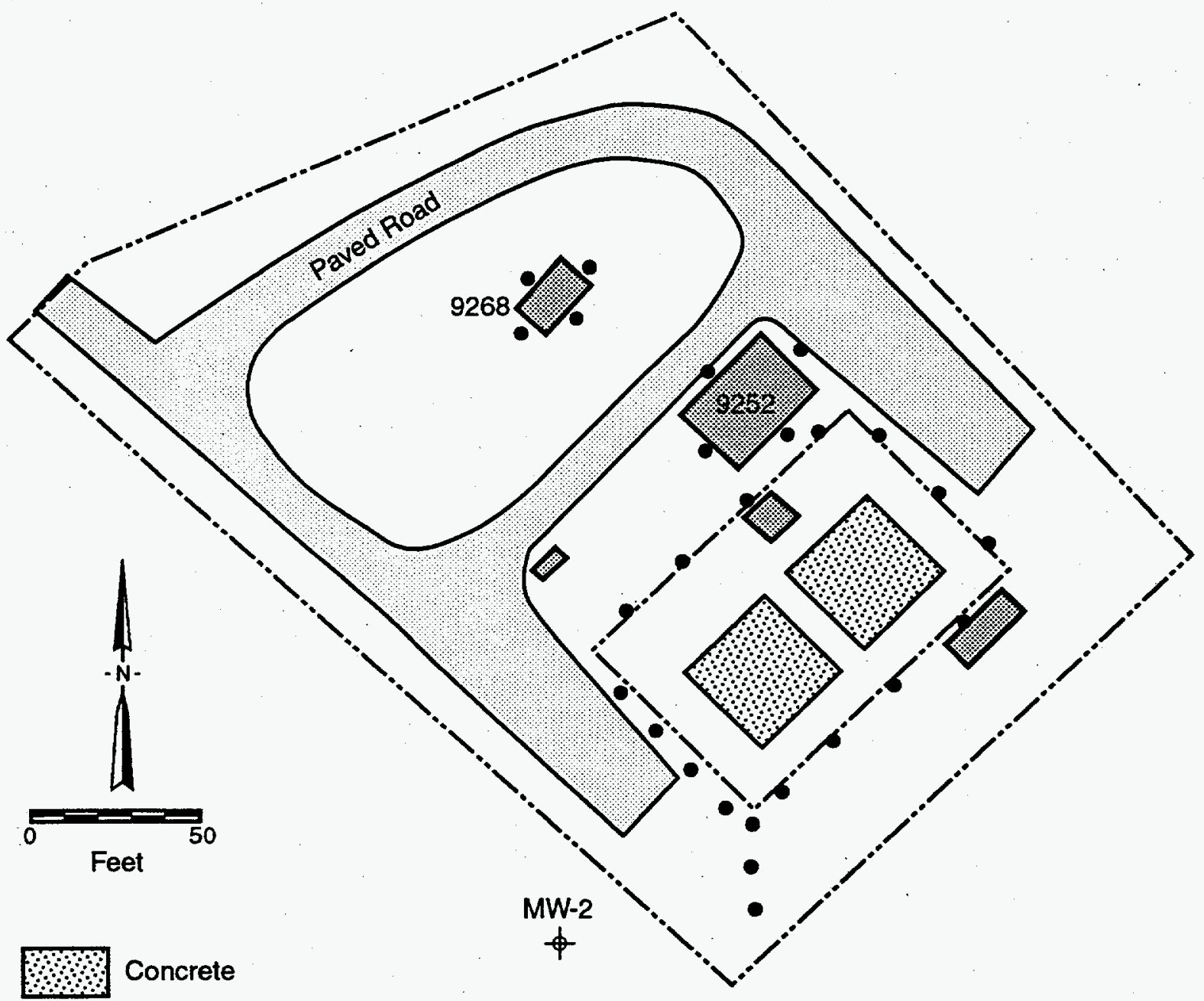

- Proposed Soil Sample Location

Buildings

Chain Link Fence \& Gates

\& Monitoring Well

FIGURE 3.21. Hot Pond and Surrounding Area 
packaged and shipped to a low-level waste (LLW) repository. The concrete, which showed no visible cracks as of 1990 , was then cleaned and scrubbed, a sealer was applied, and the site was surveyed for residual radiation. No sludge or polyethylene remains in the ponds.

The pond is $8.84 \mathrm{~m}$ square and $0.87 \mathrm{~m}$ deep. It is surrounded by a $4.57-\mathrm{m}$ wide concrete apron and a fence with a locked gate. The apron was installed some time after the pond began operation. The pond is covered with a $1.27-\mathrm{cm}$ wire mesh screen supported by an I-beam frame, a covering that prohibits inadvertent entry. Normally the pond is dry, although rainstorms can cover the pond bottom with rainwater. The amount of water depends on precipitation and evaporation.

The depth to groundwater under the site varies from 23 to $41 \mathrm{~m}$. The site is approximately $1,707 \mathrm{~m}$ above msl. Table 3.45 provides a physical description of the site.

\section{Description of Contamination}

Since the sludge and liquid in the pond have already been removed, only residual contamination in the concrete and in the soil beneath the pond are of concern. Table 3.46 provides an estimate of the quantity of various contaminants that may be present in the pond concrete. These estimates were based on beta/ gamma measurements made in 1992 that varied between 360 and $1200 \mu \mathrm{R} / \mathrm{hr}$ at five different locations within the pond (one at each corner and one right in the middle of the pond) and on the relative ratio of measured contaminant concentrations in the sludge before it was removed. 
TABLE 3.45. Description of Hot Pond

\begin{tabular}{||l|c|c||}
\hline \multicolumn{1}{|c|}{ Dimension } & Values & Units \\
\hline \hline Length & 8.84 & $\mathrm{~m}$ \\
\hline Width & 8.84 & $\mathrm{~m}$ \\
\hline Depth & 0.87 & $\mathrm{~m}$ \\
\hline Capacity & 68,130 & $\mathrm{~L}$ \\
\hline Construction material & concrete & \\
\hline Liner material & polyethylene & \\
\hline Thickness of Concrete & 10.2 & $\mathrm{~cm}$ \\
\hline Length of Operation & $1963-1985$ & $\mathrm{yr}$ \\
\hline
\end{tabular}

TABLE 3.46. Residual Contaminants in the Concrete

\begin{tabular}{|l|l|c|}
\hline \multicolumn{1}{|c|}{ Contaminant } & \multicolumn{1}{|c|}{ Inventory } & Units \\
\hline \hline $\mathrm{Pu}-238$ & $5.7 \times 10^{-2}$ & $\mathrm{Ci}$ \\
\hline $\mathrm{Pu}-239$ & $1.1 \times 10^{-2}$ & $\mathrm{Ci}$ \\
\hline $\mathrm{Am}-241$ & 0.29 & $\mathrm{Ci}$ \\
\hline $\mathrm{Cm}-244$ & $1.8 \times 10^{-3}$ & $\mathrm{Ci}$ \\
\hline $\mathrm{Sr}-90$ & 0.72 & $\mathrm{Ci}$ \\
\hline $\mathrm{Cs}-137$ & $6.3 \times 10^{-3}$ & $\mathrm{Ci}$ \\
\hline $\mathrm{Co}-60$ & $1.5 \times 10^{-6}$ & $\mathrm{Ci}$ \\
\hline $\mathrm{Cs}-134$ & $2.9 \times 10^{-6}$ & $\mathrm{Ci}$ \\
\hline
\end{tabular}

\section{Description of Soil Contamination}

In 1990, ten soil samples were taken from immediately beneath the concrete of the north and south ponds: one each from the center and from corners of both ponds. These cores were scanned for beta and gamma radiation; radiation levels decreased with increasing depth throughout the length of each core plug. 
Investigators took 20 soil samples below the core holes: ten from the 0 - to 15.24- cm depth, and ten from the 15.24- to 30.48-cm depth. Three of the 0 - to $15.24-\mathrm{cm}$ samples had elevated Cs-137 levels ranging from 11.3 to $71.1 \mathrm{pCi} / \mathrm{g}$. All samples from the $15.24-$ to $30.48-\mathrm{cm}$ depth had beta and gamma activity equal to background levels, which is $1 \mathrm{pCi} / \mathrm{g}$.

It is possible that contaminated concrete or core drilling fluid had mixed with the surface soil and caused the elevated Cs-137 levels. However, because three of the samples had activities of 10 to 70 times the background level, it is also possible that the pond leaked contaminants to the underlying soil. The available information suggests that contamination beneath the ponds is likely due to random leakage.

Table 3.47 provides an estimate of the quantity of various contaminants believed to have leaked into the soil beneath the pond. These estimates were based on assuming an average Cs-137 concentration in the soil of $9.4 \mathrm{pCi} / \mathrm{g}$ and using the MEPAS model to simulate infiltration from the pond sludge (using the concentration of each contaminant in the sludge before it was removed) into the soil. The flux rate for $\mathrm{Cs}-137$ through the pond floor was calibrated using the MEPAS model to yield the measured average concentration of Cs-137 in the soil. The flux rate for each of the other contaminants is directly proportional to the Cs-137 flux rate and the following ratio:

$\left[\frac{\text { contaminant concentration in sludge }}{\text { distribution coefficient }\left(\mathrm{k}_{\mathrm{d}}\right) \text { of contaminant in pond floor medium }}\right]$

$\left[\frac{\mathrm{Cs}-137 \text { concentration in sludge }}{\mathrm{k}_{\mathrm{d}} \text { of } \mathrm{Cs}-137 \text { in pond floor medium }}\right]$


TABLE 3.47. Description of Contaminants in the Soil

\begin{tabular}{|l|c|c|}
\hline Contaminant & Inventory & Units \\
\hline \hline $\mathrm{Pu}-238$ & $1.47 \times 10^{-2}$ & $\mathrm{Ci}$ \\
\hline $\mathrm{Pu}-239$ & $8.84 \times 10^{-3}$ & $\mathrm{Ci}$ \\
\hline $\mathrm{Am}-241$ & $5.3 \times 10^{-10}$ & $\mathrm{Ci}$ \\
\hline $\mathrm{Cm}-243$ & $3.92 \times 10^{-11}$ & $\mathrm{Ci}$ \\
\hline $\mathrm{Cm}-244$ & $1.69 \times 10^{-11}$ & $\mathrm{Ci}$ \\
\hline $\mathrm{Sr}-90$ & $2.33 \times 10^{-2}$ & $\mathrm{Ci}$ \\
\hline $\mathrm{Co}-60$ & $1.29 \times 10^{-15}$ & $\mathrm{Ci}$ \\
\hline $\mathrm{Cs}-134$ & $3.92 \times 10^{-11}$ & $\mathrm{Ci}$ \\
\hline $\mathrm{Cs}-137$ & $1.68 \times 10^{-4}$ & $\mathrm{Ci}$ \\
\hline
\end{tabular}

The soil concentration and inventory for each contaminant was then estimated from the flux rate using the MEPAS model. Because detailed data were not available on the extent or depth of contamination in the soil, the distribution of each contaminant in the soil was estimated with a one-dimensional contaminant transport model that used the environmental parameters for the environmental setting described below. The results of this effort are presented in Table 3.48.

\section{Environmental Setting}

The environmental setting for this source term description is provided in Section 4.6. 
TABLE 3.48. Vertical Distribution of Contaminants in the Soil Column Beneath the Hot Pond

\begin{tabular}{|c|c|c|c|c|c|c|c|c|}
\hline \multirow[b]{2}{*}{$\begin{array}{l}\text { Inventory } \\
\text { Fraction (\%) }\end{array}$} & \multicolumn{4}{|c|}{ Pu-238 } & \multicolumn{4}{|c|}{$\mathrm{Pu}-239$} \\
\hline & $\begin{array}{c}\text { Depth } \\
\text { (cm) }\end{array}$ & $\begin{array}{c}\text { Concentration } \\
(\mathrm{pCi} / \mathrm{g})\end{array}$ & $\begin{array}{l}\text { Inventory } \\
\text { (Ci) }\end{array}$ & $\begin{array}{c}\text { Soil } \\
\text { Volume } \\
\left(\mathrm{m}^{3}\right)\end{array}$ & $\begin{array}{c}\text { Depth } \\
\text { (cm) }\end{array}$ & $\begin{array}{c}\text { Concentration } \\
(\mathrm{pCi} / \mathrm{g})\end{array}$ & $\begin{array}{c}\text { Inventory } \\
\text { (Ci) }\end{array}$ & $\begin{array}{c}\text { Soil } \\
\text { Volume } \\
\left(\mathrm{m}^{3}\right)\end{array}$ \\
\hline 0.0 & $=$ & 3330 & -- & $-\cdots$ & -- & 2300 & -- & -- \\
\hline 50.0 & 1.9 & 2590 & $7.35 \times 10^{-3}$ & $\overline{1.5}$ & 1.9 & 1800 & $4.42 \times 10^{-3}$ & $\overline{1.5}$ \\
\hline 90.0 & 4.3 & 870 & $1.3 \times 10^{-2}$ & 3.4 & 4.3 & 620 & $7.96 \times 10^{-3}$ & 3.4 \\
\hline 99.0 & 7.2 & 115 & $1.46 \times 10^{-2}$ & 5.6 & 7.2 & 83 & $8.75 \times 10^{-3}$ & 5.6 \\
\hline 99.9 & 9.5 & 13 & $1.47 \times 10^{-2}$ & 7.5 & 9.5 & 10 & $8.83 \times 10^{-3}$ & 7.5 \\
\hline \multirow[t]{3}{*}{100.0} & 15.7 & $6.3 \times 10^{-3}$ & $1.47 \times 10^{-2}$ & 12.3 & 15.7 & $4.7 \times 10^{-3}$ & $8.84 \times 10^{-3}$ & 12.3 \\
\hline & \multicolumn{4}{|c|}{$\mathrm{Am}-241$} & \multicolumn{4}{|c|}{$\mathrm{Cm}-244$} \\
\hline & $\begin{array}{l}\text { Depth } \\
\text { (cm) }\end{array}$ & $\begin{array}{c}\text { Concentration } \\
(\mathrm{pCi} / \mathrm{g})\end{array}$ & $\begin{array}{l}\text { Inventory } \\
\text { (Ci) }\end{array}$ & $\begin{array}{c}\text { Soil } \\
\text { Volume } \\
\left(\mathrm{m}^{3}\right)\end{array}$ & $\begin{array}{l}\text { Depth } \\
\text { (cm) }\end{array}$ & $\begin{array}{l}\text { Concentration } \\
(\mathrm{pCi} / \mathrm{g})\end{array}$ & $\begin{array}{c}\text { Inventory } \\
\text { (Ci) }\end{array}$ & $\begin{array}{c}\text { Soil } \\
\text { Volume } \\
\left(\mathrm{m}^{3}\right)\end{array}$ \\
\hline 0.0 & - & $3.9 \times 10^{-4}$ & - & -- & - & $6.6 \times 10^{-6}$ & -- & -- \\
\hline$\overline{50.0}$ & 0.6 & $3.2 \times 10^{-4}$ & $2.65 \times 10^{-10}$ & 0.47 & 0.58 & $5.3 \times 10^{-6}$ & $8.45 \times 10^{-12}$ & 0.45 \\
\hline 90.0 & 1.5 & $9.9 \times 10^{-5}$ & $4.77 \times 10^{-10}$ & 1.2 & 1.4 & $1.7 \times 10^{-6}$ & $1.52 \times 10^{-11}$ & 1.1 \\
\hline 99.0 & 2.6 & $1.1 \times 10^{-5}$ & $5.25 \times 10^{-10}$ & 2.0 & 2.45 & $2.0 \times 10^{-7}$ & $1.67 \times 10^{-11}$ & 1.9 \\
\hline 99.9 & 3.3 & $1.6 \times 10^{-6}$ & $5.29 \times 10^{-10}$ & 2.55 & 3.3 & $2.0 \times 10^{-8}$ & $1.69 \times 10^{-11}$ & 2.6 \\
\hline \multirow[t]{3}{*}{100.0} & 5.7 & $2.6 \times 10^{-10}$ & $5.3 \times 10^{-10}$ & 4.5 & $\overline{5.3}$ & $1.7 \times 10^{-11}$ & $1.69 \times 10^{-11}$ & 4.2 \\
\hline & \multicolumn{4}{|c|}{ Sr-90 } & \multicolumn{4}{|c|}{ Cs-137 } \\
\hline & $\begin{array}{l}\text { Depth } \\
\text { (cm) }\end{array}$ & $\begin{array}{c}\text { Concentration } \\
(\mathrm{pCi} / \mathrm{g})\end{array}$ & $\begin{array}{l}\text { Inventory } \\
\text { (Ci) }\end{array}$ & $\begin{array}{c}\text { Soil } \\
\text { Volume } \\
\left(\mathrm{m}^{3}\right)\end{array}$ & $\begin{array}{l}\text { Depth } \\
\text { (cm) }\end{array}$ & $\begin{array}{c}\text { Concentration } \\
(\mathrm{pCi} / \mathrm{g})\end{array}$ & $\begin{array}{l}\text { Inventory } \\
\text { (Ci) }\end{array}$ & $\begin{array}{c}\text { Soil } \\
\text { Volume } \\
\left(\mathbf{m}^{3}\right) \\
\end{array}$ \\
\hline 0.0 & - & 6250 & - & -- & -- & 67 & - & -- \\
\hline 50.0 & 1.2 & 4720 & $1.17 \times 10^{-2}$ & 0.97 & 0.85 & 50 & $8.4 \times 10^{-5}$ & 0.67 \\
\hline 90.0 & 2.8 & 1460 & $2.1 \times 10^{-2}$ & 2.2 & 1.9 & 16 & $1.5 \times 10^{-4}$ & 1.5 \\
\hline 99.0 & 4.7 & 170 & $2.31 \times 10^{-2}$ & 3.7 & 3.2 & 1.9 & $1.66 \times 10^{-4}$ & 2.5 \\
\hline 99.9 & 6.2 & 18 & $2.33 \times 10^{-2}$ & 4.9 & 4.3 & 0.21 & $1.68 \times 10^{-4}$ & 3.3 \\
\hline \multirow[t]{3}{*}{100.0} & 10.0 & $1.4 \times 10^{-2}$ & $2.33 \times 10^{-2}$ & 7.8 & 6.8 & $1.7 \times 10^{-4}$ & $1.68 \times 10^{-4}$ & 5.3 \\
\hline & \multicolumn{4}{|c|}{$\mathrm{Co}-60$} & \multicolumn{4}{|c|}{ Cs-134 } \\
\hline & $\begin{array}{l}\text { Depth } \\
\text { (cm) }\end{array}$ & $\begin{array}{c}\text { Concentration } \\
(\mathrm{pCi} / \mathrm{g})\end{array}$ & $\begin{array}{l}\text { Inventory } \\
\text { (Ci) }\end{array}$ & $\begin{array}{c}\text { Soil } \\
\text { Volume } \\
\left(\mathrm{m}^{3}\right)\end{array}$ & $\begin{array}{l}\text { Depth } \\
\text { (cm) }\end{array}$ & $\begin{array}{c}\text { Concentration } \\
(\mathrm{pCi} / \mathrm{g})\end{array}$ & $\begin{array}{l}\text { Inventory } \\
\text { (Ci) }\end{array}$ & $\begin{array}{c}\text { Soil } \\
\text { Volume } \\
\left(\mathbf{m}^{\mathbf{3}}\right)\end{array}$ \\
\hline 0.0 & - & $1.9 \times 10^{-1}$ & -- & - & -- & $2.7 \times 10^{-7}$ & -- & -- \\
\hline 50.0 & 3.9 & $1.5 \times 10^{-1}$ & $6.5 \times 10^{-6}$ & 3.0 & 0.64 & $2.1 \times 10^{-7}$ & $1.96 \times 10^{-11}$ & $\overline{0.5}$ \\
\hline 90.0 & 8.7 & $4.7 \times 10^{-2}$ & $1.16 \times 10^{-5}$ & 6.8 & 1.5 & $7.2 \times 10^{-8}$ & $3.53 \times 10^{-11}$ & 1.1 \\
\hline 99.0 & 14.5 & $5.4 \times 10^{-3}$ & $1.28 \times 10^{-5}$ & 11.3 & 2.4 & $7.9 \times 10^{-9}$ & $3.88 \times 10^{-11}$ & 1.9 \\
\hline 99.9 & 19.3 & $6.5 \times 10^{-4}$ & $1.29 \times 10^{-5}$ & 15.1 & 3.2 & $7.8 \times 10^{-10}$ & $3.92 \times 10^{-11}$ & 2.5 \\
\hline \multirow[t]{3}{*}{100.0} & 32.8 & $4.2 \times 10^{-7}$ & $1.29 \times 10^{-5}$ & 25.7 & 5.6 & $3.9 \times 10^{-12}$ & $3.92 \times 10^{-11}$ & 4.4 \\
\hline & \multicolumn{4}{|c|}{$\mathrm{Cm}-243$} & & & & \\
\hline & $\begin{array}{l}\text { Depth } \\
\text { (cm) }\end{array}$ & $\begin{array}{l}\text { Concentration } \\
(\mathrm{pCi} / \mathrm{g})\end{array}$ & $\begin{array}{l}\text { Inventory } \\
\text { (Ci) }\end{array}$ & $\begin{array}{c}\text { Soil } \\
\text { Volume } \\
\left(\mathrm{m}^{3}\right)\end{array}$ & & & & \\
\hline 0.0 & -- & $1.9 \times 10^{-5}$ & -- & -- & & & & \\
\hline 50.0 & 0.59 & $1.6 \times 10^{-5}$ & $1.96 \times 10^{-11}$ & 0.46 & & & & \\
\hline 90.0 & 1.5 & $4.8 \times 10^{-6}$ & $3.53 \times 10^{-11}$ & 1.2 & & & & \\
\hline 99.0 & 2.5 & $5.4 \times 10^{-7}$ & $3.88 \times 10^{-11}$ & 2.0 & & & & \\
\hline 99.9 & 3.3 & $7.8 \times 10^{-8}$ & $3.92 \times 10^{-11}$ & 2.6 & & & & \\
\hline 100.0 & 5.5 & $3.1 \times 10^{-11}$ & $3.92 \times 10^{-11}$ & 4.3 & & & & \\
\hline
\end{tabular}




\subsection{UNDERGROUND STORAgE TANK}

\section{Overview of Release Site}

The representative underground storage tank is a collection tank for concentrated low-level liquid waste (LLLW), similar to an underground tank located at the Oak Ridge National Laboratory (ORNL) (Autrey et al. 1990; Horton 1984). Figure 3.22 presents a plan view of the South Tank Farm and the location of Tank W-7, the particular subject of this source description. The sources of the wastes are laboratory and process buildings. The waste that was discharged to the LLW system is not well characterized, partly due to the radioactivity of some of the waste. The activity of radioactive wastes was generally greater than $10,000 \mathrm{pCi} / \mathrm{L}$.

\section{Physical Description}

The tank is constructed of concrete (gunite) with $19.05-\mathrm{cm}$-thick, 3.66-m-tall sidewalls and a 7.62-cm-thick bottom gunite liner on top of a concrete pad. The inside diameter of the tank is $15.24 \mathrm{~m}$. The tank dome is $25.4 \mathrm{~cm}$ thick at the center and thicker toward the sidewalls. The dome is $1.9 \mathrm{~m}$ higher in the center than at the sidewalls. The roof and sidewalls include $0.95-\mathrm{cm}$ and $1.27-\mathrm{cm}$ steel reinforcement bars as well as wire mesh. Overburden depth is approximately $1.52 \mathrm{~m}$. Figure 3.23 presents a schematic of a gunite tank. The thickness of the pad beneath the tank is unknown, but it has a larger diameter than the tank plus a curb and gutter system that drains to a drywell. The drywell is accessible and connects to a common drain for pumping to an equalization basin. In 1980, 86-cm access shafts were installed through the soil cover and tank dome. The depth to groundwater at the site is 3.05 to $4.57 \mathrm{~m}$. Table 3.49 provides a physical description of the tank. 


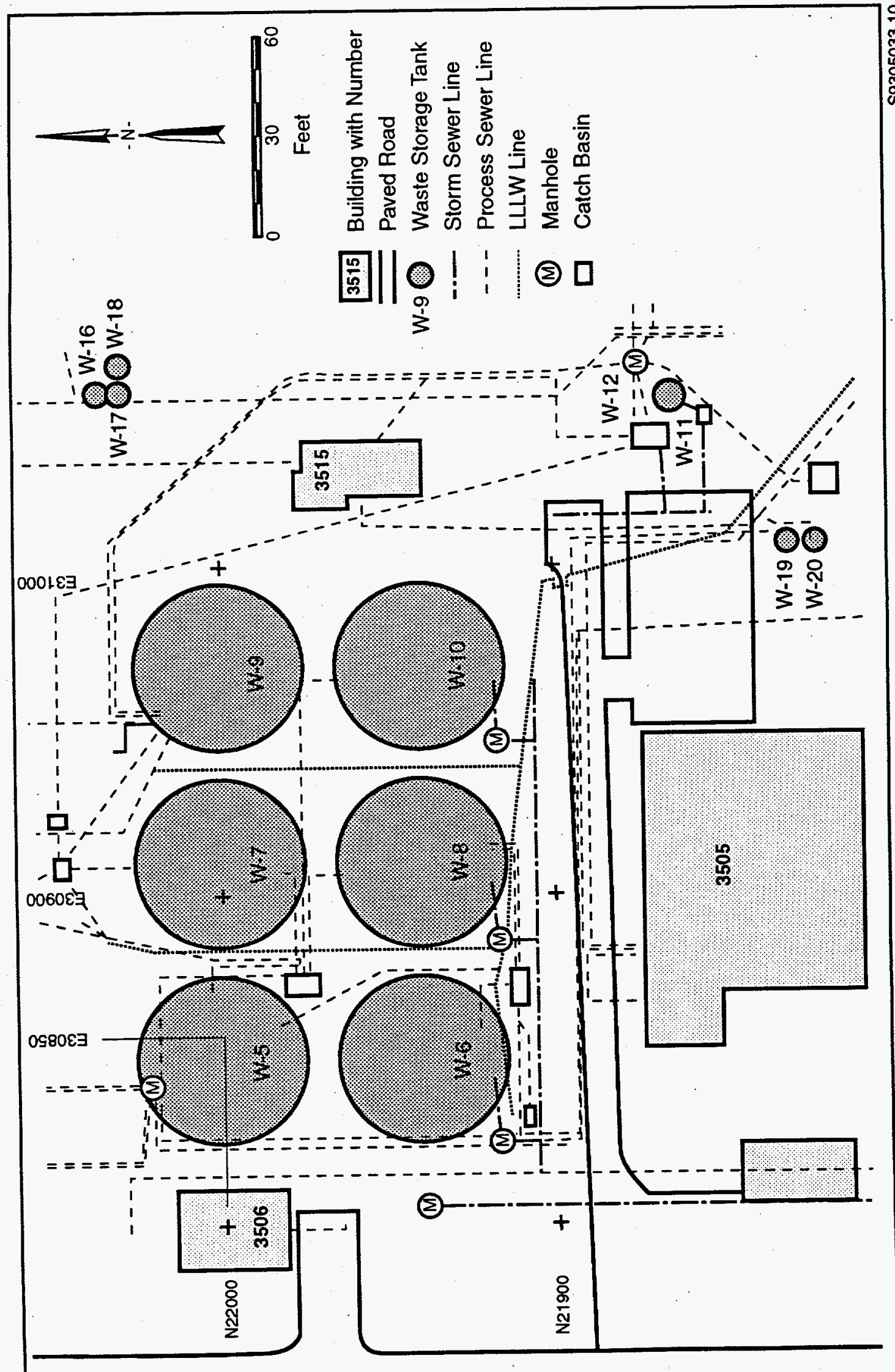

है 


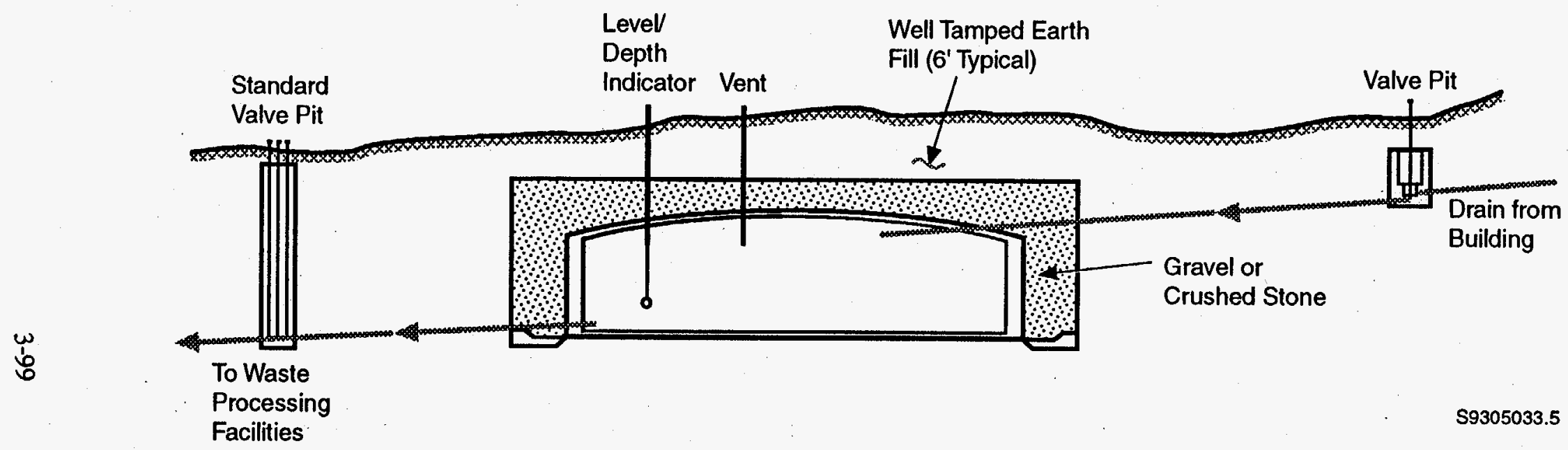

FIGURE 3.23. Typical Concrete (Gunite) Waste Tank Installation 
TABLE 3.49. Description of Underground Storage Tank

\begin{tabular}{|l|c|c||}
\hline \multicolumn{1}{|c|}{ Dimension } & Values & Units \\
\hline \hline Inside Diameter & 15.24 & $\mathrm{~m}$ \\
\hline Height & 5.56 & $\mathrm{~m}$ \\
\hline Wall Thickness & 19.05 & $\mathrm{~cm}$ \\
\hline Overburden & 1.83 & $\mathrm{~m}$ \\
\hline Construction material & \multicolumn{2}{|c|}{ reinforced concrete } \\
\hline Operating period & $1943-1978$ & \\
\hline Service life & 35 & $\mathrm{yr}$ \\
\hline Tank capacity & 643,520 & $\mathrm{~L}$ \\
\hline Residual sludge (volume) & 6,435 & $\mathrm{~L}$ \\
\hline
\end{tabular}

\section{Description of Contamination}

It is known that $45,800 \mathrm{~L}$ of liquid/sludge residual exist in the tank, of which $26,500 \mathrm{~L}$ is liquid and $19,300 \mathrm{~L}$ is sludge. For the purposes of remediation only $1 \%$ of the tank capacity, or $6,435 \mathrm{~L}$, is assumed to be occupied by contaminated sludge. All of the pumpable liquid and most of the sludge residual known to be in the tank are assumed to be removed as a waste management operation.

Table 3.50 provides a description of the sludge contaminants in the tank. The primary contaminant in the sludge is uranium.

\section{Environmental Setting}

The environmental setting for this source term description is provided in Section 4.1. 
TABLE 3.50. Description of Contaminants in Tank Sludge

\begin{tabular}{||l|c|c|c|c||}
\hline \multirow{2}{*}{ Constituent } & \multicolumn{4}{|c|}{ Sludge } \\
\cline { 2 - 5 } & Concentration & Units & Inventory & Units \\
\hline \hline $\mathrm{Cr}$ & 600 & $\mathrm{mg} / \mathrm{kg}$ & 8.5 & $\mathrm{~kg}$ \\
\hline $\mathrm{Hg}$ & 141 & $\mathrm{mg} / \mathrm{kg}$ & 1.8 & $\mathrm{~kg}$ \\
\hline $\mathrm{Pb}$ & 300 & $\mathrm{mg} / \mathrm{kg}$ & 3.87 & $\mathrm{~kg}$ \\
\hline $\mathrm{U}$ & 45,000 & $\mathrm{mg} / \mathrm{kg}$ & 580 & $\mathrm{~kg}$ \\
\hline $\mathrm{Bis}(2-$-ethylthexyl) phthalate & 57 & $\mathrm{mg} / \mathrm{kg}$ & 0.73 & $\mathrm{~kg}$ \\
\hline $\mathrm{Sr}-90$ & $3.2 \times 10^{4}$ & $\mathrm{nCi} / \mathrm{g}$ & 412 & $\mathrm{Ci}$ \\
\hline $\mathrm{U}-233$ & $2.1 \times 10^{4}$ & $\mathrm{nCi} / \mathrm{g}$ & 270 & $\mathrm{Ci}$ \\
\hline $\mathrm{Am}-241$ & 14.6 & $\mathrm{nCi} / \mathrm{g}$ & 0.187 & $\mathrm{Ci}$ \\
\hline $\mathrm{Pu}-238$ & 15.4 & $\mathrm{nCi} / \mathrm{g}$ & 0.197 & $\mathrm{Ci}$ \\
\hline $\mathrm{Pu}-239$ & 29.7 & $\mathrm{nCi} / \mathrm{g}$ & 0.38 & $\mathrm{Ci}$ \\
\hline $\mathrm{Cm}-244$ & 64.9 & $\mathrm{nCi} / \mathrm{g}$ & 0.84 & $\mathrm{Ci}$ \\
\hline $\mathrm{Cs}-134$ & 114 & $\mathrm{nCi} / \mathrm{g}$ & 1.47 & $\mathrm{Ci}$ \\
\hline Eu-152 & 2.7 & $\mathrm{nCi} / \mathrm{g}$ & 0.035 & $\mathrm{Ci}$ \\
\hline Eu-154 & 43 & $\mathrm{nCi} / \mathrm{g}$ & 0.33 & $\mathrm{Ci}$ \\
\hline $\mathrm{H}-3$ & 35 & $\mathrm{nCi} / \mathrm{g}$ & 0.45 & $\mathrm{Ci}$ \\
\hline $\mathrm{Co}-60$ & 3.2 & $\mathrm{nCi} / \mathrm{g}$ & 0.041 & $\mathrm{Ci}$ \\
\hline
\end{tabular}




\section{CHAPTER 4: DESCRIPTIONS OF ENVIRONMENTAL SETTINGS}

This section contains six different representative environmental settings ranging from arid to humid climates, rural to urban locations, and shallow to deep groundwater depths. The environmental setting information consists of climatological data, geohydrologic data, population distribution data, exposure location data (receptor information), and data on the distribution of agricultural products.

\subsection{OAK RIDGe National Laboratory}

The Oak Ridge National Laboratory (ORNL) is located on $36 \mathrm{~km}^{2}\left(14 \mathrm{mi}^{2}\right.$ ) (the main laboratory area covers $4.5 \mathrm{~km}^{2}\left[1.7 \mathrm{mi}^{2}\right]$ ) in the southcentral portion of the $143 \mathrm{~km}^{2}$ (55 $\mathrm{mi}^{2}$ ) Oak Ridge Reservation (Figure 4.1). The site is located in the rolling topography of the Bethel and Melton Valleys between the Cumberland and Great Smoky Mountains. Surrounding areas are agricultural and residential.

The climate of the region can be categorized as continental - warm summer, a climate characteristic of much of the mid-western and eastern states (see Table 4.1 for detailed climatic information). Meteorological data are available from the site and from Oak Ridge, Tennessee. Precipitation averages about $140 \mathrm{~cm}$ (55 in.) per year. Site winds are characterized using joint frequency distributions obtained from ORNL. 


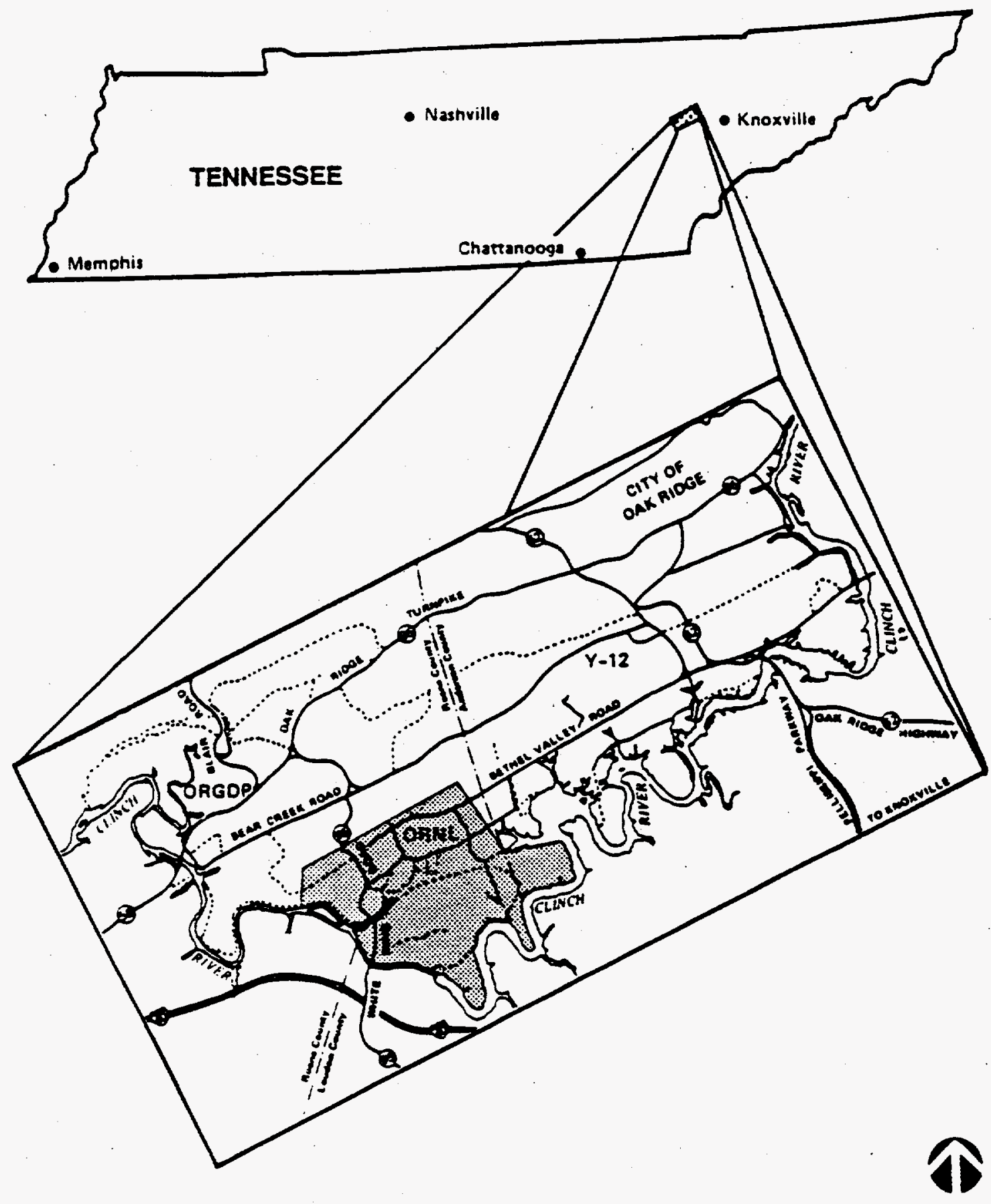

FIGURE 4.1. Location of the Oak Ridge National Laboratory 


\section{TABLE 4.1. ORNL Average Local Climatology ${ }^{(\mathrm{a}, \mathrm{b})}$}

Oak Ridge Airport, Oak Ridge, Tennessee

Elevation:

Latitude:

Annual mean air temp:

Anemometer height:

Mean annual wind speed:

Fastest 1-min Wind speed:

Annual precipitation:

Precipitation days:

Thunderstorms freq:

Avg morning mixing ht:

Avg afternoon mixing ht:

Topsoil moisture capacity:
$268 \mathrm{~m}$

$35.93^{\circ} \mathrm{N}$

$57.0^{\circ} \mathrm{F}$

$9.1 \mathrm{~m}$

4 mph

$59 \mathrm{mph}$

54.8 in.

$128 \mathrm{yr}^{-1}$

$51 \mathrm{yr}^{-1}$

$450 \mathrm{~m}$

$1600 \mathrm{~m}$

$19 \mathrm{~cm}$

\begin{tabular}{|c|c|c|c|c|c|c|c|}
\hline \multirow[b]{2}{*}{ Month } & \multicolumn{5}{|c|}{ Monthly Averages } & \multicolumn{2}{|c|}{ Daily RH } \\
\hline & $\begin{array}{c}\text { Temp. } \\
\left({ }^{\circ} \mathrm{F}\right)\end{array}$ & $\begin{array}{l}\text { Precip. } \\
\text { (inches) }\end{array}$ & Wind Speed (mph) & $\begin{array}{l}\text { Cloud Cover } \\
\text { (tenths) }\end{array}$ & $\begin{array}{l}\text { Precip. } \\
\text { Days (\#) }\end{array}$ & $\begin{array}{c}\operatorname{Max} \\
(\%)\end{array}$ & $\begin{array}{l}\text { Min } \\
(\%)\end{array}$ \\
\hline Jan & 37 & 5.25 & 4.8 & 6.7 & 12.4 & 80 & 64 \\
\hline Feb & 40 & 4.60 & 5.0 & 6.5 & 11.4 & 79 & 59 \\
\hline Mar & 48 & 6.21 & 5.3 & 6.5 & 12.6 & 79 & 55 \\
\hline Apr & 58 & 4.41 & 5.7 & 5.9 & 10.8 & 80 & 52 \\
\hline May & 66 & 4.23 & 4.5 & 5.9 & 10.7 & 86 & 57 \\
\hline Jun & 73 & 4.26 & 4.2 & 5.5 & 10.3 & 88 & 59 \\
\hline Jul & 77 & 5.21 & 3.9 & 5.8 & 11.9 & 90 & 62 \\
\hline Aug & 76 & 3.75 & 3.75 & 5.5 & 10.4 & 92 & 61 \\
\hline Sep & 70 & 3.80 & 3.8 & 5.6 & 8.3 & 91 & 60 \\
\hline Oct & 58 & 2.89 & 3.6 & 5.0 & 7.9 & 89 & 5.6 \\
\hline Nov & 57 & 4.50 & 4.1 & 6.1 & 10.1 & 83 & 59 \\
\hline Dec & 40 & 5.65 & 4.5 & 6.5 & 10.9 & 82 & 63 \\
\hline
\end{tabular}

(a) Meteorological parameters are presented using the units with which they are routinely measured (e.g., temperature in ${ }^{\circ} \mathrm{F}$, wind speed in $\mathrm{mph}$ ). Temperature and precipitation averages are based on a 30-year climatologically representative period (1951 - 1980). Other averages are based on 26 to 47 years of data.

(b) MEPAS Parameters: Climatic region index: 6

Precipitation-evaporation index: 116

Soil cons. serv. curve number: 71

The site is bounded by the Clinch River to the south and west. The White Oak Creek flows through the site and empties into White Oak Lake, which drains into the Clinch River. Tributaries of the White Oak include First Creek, Fifth 
Creek, and Northwest Tributary. Raccoon Creek flows through the site directly into the Clinch River. The Clinch River flows to the southwest into Watts Bar Lake on the Tennessee River. Water levels in the Clinch River are regulated by the Tennessee Valley Authority. Groundwater occurs in all formations that outcrop at the ORNL. Groundwater flow can be modeled as having two flow regimes: a residual soil flow system and a bedrock flow system. The two flow regimes are hydraulically connected through a transition zone of weathered rock. The flow of groundwater in the soil system is from the ridge crests toward the valleys (where water discharges to streams and to White Oak Lake). The bedrock aquifer consists of shales, siltstones, and limestones. Detailed geohydrologic data are presented in Table 4.2 and exposure/receptor data are presented in Table 4.3.

Within a few $\mathrm{km}$ of the site, the local population is about 30,000 . Within $80 \mathrm{~km}(50 \mathrm{mi})$ of the facility, the population numbers about one million people. Detailed population data are presented in Table 4.4, and data on the distribution of agricultural products are presented in Table 4.5.

\subsection{Pinellas Plant}

The Pinellas Plant occupies about $0.40 \mathrm{~km}^{2}\left(0.16 \mathrm{mi}^{2}\right)$ of land in Pinellas County near St. Petersburg, Florida, between the Largo and Pinellas Parks (see Figure 4.2).

The climate of the region can be categorized as subtropical marine, a climate characteristic of much of the gulf and southern Atlantic coastal areas (see Table 4.6 for detailed climatic information). Meteorological data are obtained from Tampa International Airport in Tampa, Florida. Precipitation averages about $120 \mathrm{~cm}$ (47 in.) per year. Site winds are characterized using joint frequency distributions. 
TABLE 4.2. Geohydrologic Data for the ORNL

\begin{tabular}{|c|c|c|c|c|c|c|c|c|c|c|}
\hline \multirow[b]{2}{*}{ Layer(s) } & \multirow[b]{2}{*}{ Textural Name } & \multirow[b]{2}{*}{$\begin{array}{l}\text { Thickness } \\
\text { (m) }\end{array}$} & \multirow[b]{2}{*}{$\begin{array}{l}\text { Bulk } \\
\text { Density } \\
\left(\mathrm{g} / \mathrm{cm}^{3}\right)\end{array}$} & \multirow[b]{2}{*}{$\begin{array}{l}\text { Porosity } \\
\text { (\%) }\end{array}$} & \multirow[b]{2}{*}{$\begin{array}{l}\text { Field } \\
\text { Capacity } \\
(\%)\end{array}$} & \multirow{2}{*}{$\begin{array}{c}\text { Saturated } \\
\text { Hydraulic } \\
\text { Conductivity } \\
\text { (m/day) }\end{array}$} & \multicolumn{4}{|c|}{ Soil Classification ${ }^{(\text {b) }}$} \\
\hline & & & & & & & $\begin{array}{c}\text { Sand } \\
\%\end{array}$ & $\begin{array}{l}\text { Silt } \\
\%\end{array}$ & $\begin{array}{c}\text { Clay } \\
\%\end{array}$ & $\begin{array}{c}\text { Organic } \\
\%\end{array}$ \\
\hline$\overline{\text { PSZ-1 }}$ & Silty clay loam & $1.524 \mathrm{E} 0$ & 2.0 & 49.0 & 37.5 & $3.000 \mathrm{E}-1$ & $\overline{10}$ & $\overline{58}$ & $\overline{32}$ & $\overline{0}$ \\
\hline SZ & $\begin{array}{l}\text { Silty clay loam } \\
\text { Groundwater velocity }=0.25 \mathrm{~m} / \mathrm{day} \\
\text { Effective porosity }=18.0 \%\end{array}$ & $6.096 \mathrm{E} 0$ & 2.0 & 49.0 & - & $-\cdot$ & 10 & 58 & 32 & 0 \\
\hline SW & $\begin{array}{l}\text { Width of river }=115 \mathrm{~m} \\
\text { Depth of river }=4.9 \mathrm{~m} \\
\text { Annual average velocity of river }= \\
21,070 \mathrm{~m} / \text { day } \\
\text { Sediment soil classification = silty clay } \\
\text { loam }(8 \%, 48 \%, 32 \%)\end{array}$ & & & & & & & & & 3 \\
\hline
\end{tabular}


TABLE 4.3. Exposure Data for the ORNL

\begin{tabular}{|c|c|c|c|c|c|c|c|c|c|c|c|}
\hline $\begin{array}{l}\text { Receptor } \\
\text { Name }\end{array}$ & $\begin{array}{c}\text { Drinking Water } \\
\text { Population }\end{array}$ & $\begin{array}{l}\text { Distance to } \\
\text { Receptor (m) }\end{array}$ & $\begin{array}{c}\text { Leafy } \\
\text { Vegetable } \\
(\mathrm{kg} / \mathrm{yr})\end{array}$ & $\begin{array}{c}\text { Other } \\
\text { Vegetables } \\
(\mathrm{kg} / \mathrm{yr})\end{array}$ & $\begin{array}{c}\text { Milk } \\
(\mathrm{kg} / \mathrm{yr})\end{array}$ & $\begin{array}{l}\text { Meat } \\
(\mathrm{kg} / \mathrm{yr})\end{array}$ & $\begin{array}{l}\text { Finfish } \\
(\mathrm{kg} / \mathrm{yr})\end{array}$ & $\begin{array}{l}\text { Shellfish } \\
(\mathrm{kg} / \mathrm{yr})\end{array}$ & $\begin{array}{l}\text { Recreation } \\
\text { Population }\end{array}$ & $\begin{array}{c}\text { Discharge } \\
\text { Rate }\left(\mathrm{m}^{3} / \text { day }\right)\end{array}$ & $\begin{array}{l}\text { Exposure } \\
\text { Routes for } \\
\text { Receptor }\end{array}$ \\
\hline $\begin{array}{l}\text { Clinch River } \\
\text { Fishing }\end{array}$ & 0 & 2,438 & $0.00 \mathrm{E}+00$ & $0.00 \mathrm{E}+00$ & $0.00 \mathrm{E}+00$ & $0.00 \mathrm{E}+00$ & $1.00 \mathrm{E}+04$ & $0.00 \mathrm{E}+00$ & 0 & $1.17 \mathrm{E}+07$ & $s w(E 2)$ \\
\hline $\begin{array}{l}\text { Clinch River } \\
\text { Irrigation }\end{array}$ & 0 & -- & $1.40 \mathrm{E}+05$ & $4.03 \mathrm{E}+05$ & $3.41 \mathrm{E}+04$ & $5.18 \mathrm{E}+05$ & $0.00 \mathrm{E}+00$ & $0.00 \mathrm{E}+00$ & 0 & $1.17 \mathrm{E}+07$ & SW(E3,E4,E5) \\
\hline $\begin{array}{l}\text { Oak Ridge } \\
\text { GDP }\end{array}$ & 2,115 & -- & $0.00 \mathrm{E}+00$ & $0.00 \mathrm{E}+00$ & $0.00 \mathrm{E}+00$ & $0.00 \mathrm{E}+\infty 0$ & $0.00 \mathrm{E}+00$ & $0.00 \mathrm{E}+00$ & 0 & $1.17 \mathrm{E}+07$ & SW(E1,E6) \\
\hline $\begin{array}{l}\text { Clinch River } \\
\text { Recreation }\end{array}$ & $\mathbf{0}$ & -- & $0.00 \mathrm{E}+00$ & $0.00 \mathrm{E}+00$ & $0.00 \mathrm{E}+00$ & $0.00 \mathrm{E}+00$ & $0.00 \mathrm{E}+00$ & $0.00 \mathrm{E}+00$ & 182,259 & $1.17 \mathrm{E}+07$ & SW(E7,E8) \\
\hline Kingston & 5,000 & - & $0.00 \mathrm{E}+00$ & $0.00 \mathrm{E}+00$ & $0.00 \mathrm{E}+00$ & $0.00 \mathrm{E}+00$ & $0.00 \mathrm{E}+00$ & $0.00 \mathrm{E}+00$ & 0 & $5.19 \mathrm{E}+07$ & SW(E1,E6) \\
\hline Rockwood & 6,500 & - & $0.00 \mathrm{E}+00$ & $0.00 \mathrm{E}+00$ & $0.00 \mathrm{E}+00$ & $0.00 \mathrm{E}+\infty 0$ & $0.00 \mathrm{E}+00$ & $0.00 \mathrm{E}+00$ & 0 & $6.72 \mathrm{E}+07$ & SW(E1,E6) \\
\hline \multicolumn{12}{|c|}{ Key for Exposure Routes } \\
\hline \multicolumn{12}{|c|}{$\begin{array}{l}\text { SW-E1 }=\text { SW } \rightarrow \text { Ingestion } \\
\text { SW-E2 }=\text { SW } \rightarrow \text { Fish/Shellfish } \rightarrow \text { Ingestion } \\
\text { SW-E6 }=\mathbf{S W} \rightarrow \text { Bathing/Showering } \\
\text { sW-E7 }=\mathbf{S W} \rightarrow \text { Recreation } \rightarrow \text { External exposure } \\
\text { SW-E8 }=\mathbf{S W} \rightarrow \text { Recreation } \rightarrow \text { Ingestion }\end{array}$} \\
\hline
\end{tabular}


TABLE 4.4. ORNL Population Distribution for Atmospheric Pathway Inhalation Population $=841,211$

\begin{tabular}{||l|r|r|r|r|r|r|r|r|r|r||}
\hline \multirow{2}{*}{ Direction } & \multicolumn{10}{|c|}{ Distance from Site (km) } \\
\cline { 2 - 12 } & 1.6 & 3.2 & 4.9 & 6.5 & 8.1 & 16.1 & 32.3 & 48.4 & 64.5 & 80.1 \\
\hline \hline N & 0 & 0 & 0 & 0 & 1887 & 4793 & 1971 & 3732 & 5106 & 6545 \\
\hline NNE & 0 & 0 & 0 & 0 & 874 & 14789 & 7922 & 11412 & 16554 & 9100 \\
\hline NE & 0 & 0 & 0 & 0 & 0 & 7336 & 13865 & 9518 & 7239 & 7152 \\
\hline ENE & 0 & 0 & 0 & 0 & 0 & 0 & 39418 & 79791 & 18513 & 15796 \\
\hline E & 0 & 0 & 0 & 0 & 0 & 2615 & 50183 & 113337 & 16826 & 16354 \\
\hline ESE & 0 & 0 & 0 & 0 & 0 & 3740 & 12447 & 37001 & 6319 & 10958 \\
\hline SE & 0 & 0 & 0 & 0 & 0 & 3519 & 6739 & 20096 & 1000 & 1689 \\
\hline SSE & 0 & 0 & 0 & 0 & 329 & 4554 & 5451 & 4180 & 1461 & 2590 \\
\hline S & 0 & 0 & 0 & 0 & 0 & 4704 & 7719 & 7810 & 6861 & 3750 \\
\hline SSW & 0 & 0 & 0 & 0 & 0 & 1307 & 3321 & 10843 & 24040 & 13900 \\
\hline SW & 0 & 0 & 0 & 0 & 0 & 1066 & 2257 & 3422 & 6691 & 13983 \\
\hline WSW & 0 & 0 & 0 & 0 & 0 & 2078 & 9447 & 6387 & 6808 & 4690 \\
\hline W & 0 & 0 & 0 & 0 & 0 & 1804 & 13807 & 5707 & 10627 & 9922 \\
\hline WNW & 0 & 0 & 0 & 0 & 0 & 1364 & 4559 & 2336 & 3385 & 4431 \\
\hline NW & 0 & 0 & 0 & 0 & 0 & 1964 & 2717 & 2340 & 3303 & 6315 \\
\hline NNW & 0 & 0 & 0 & 0 & 0 & 3187 & 2426 & 2246 & 6830 & 6156 \\
\hline
\end{tabular}

The Pinellas Plant has two drainage sub-basins. Surface water in the Starkey Road Sub-basin flows to the west, and surface water in the Cross Bayou Subbasin flows to the southeast. Both empty into Boca Ciega Bay, which is connected to the Gulf of Mexico. Groundwater is found in three hydrological units: the Surficial Aquifer ( 8 to $120 \mathrm{~m}$ [25 to $400 \mathrm{ft}$ ] thick), the Upper Confining Bed of the Upper Floridian Aquifer (15 to $30 \mathrm{~m}$ [50 to $100 \mathrm{ft}$ ] thick of marl and clay), and the Upper Floridian Aquifer (hundreds to thousands of

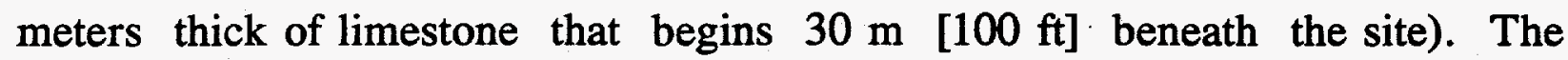


TABLE 4.5. Distribution of Agriculture Products Around the ORNL

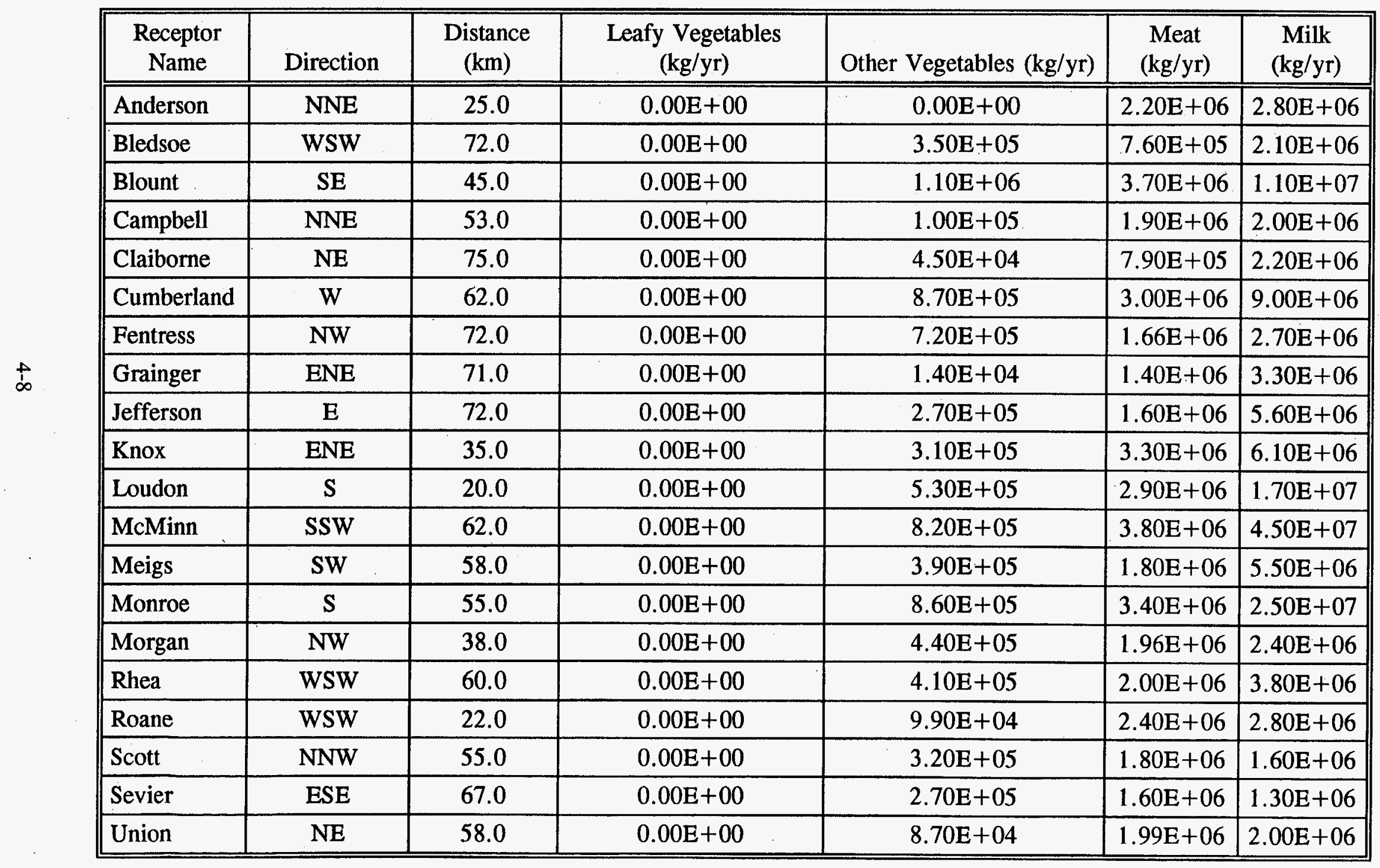




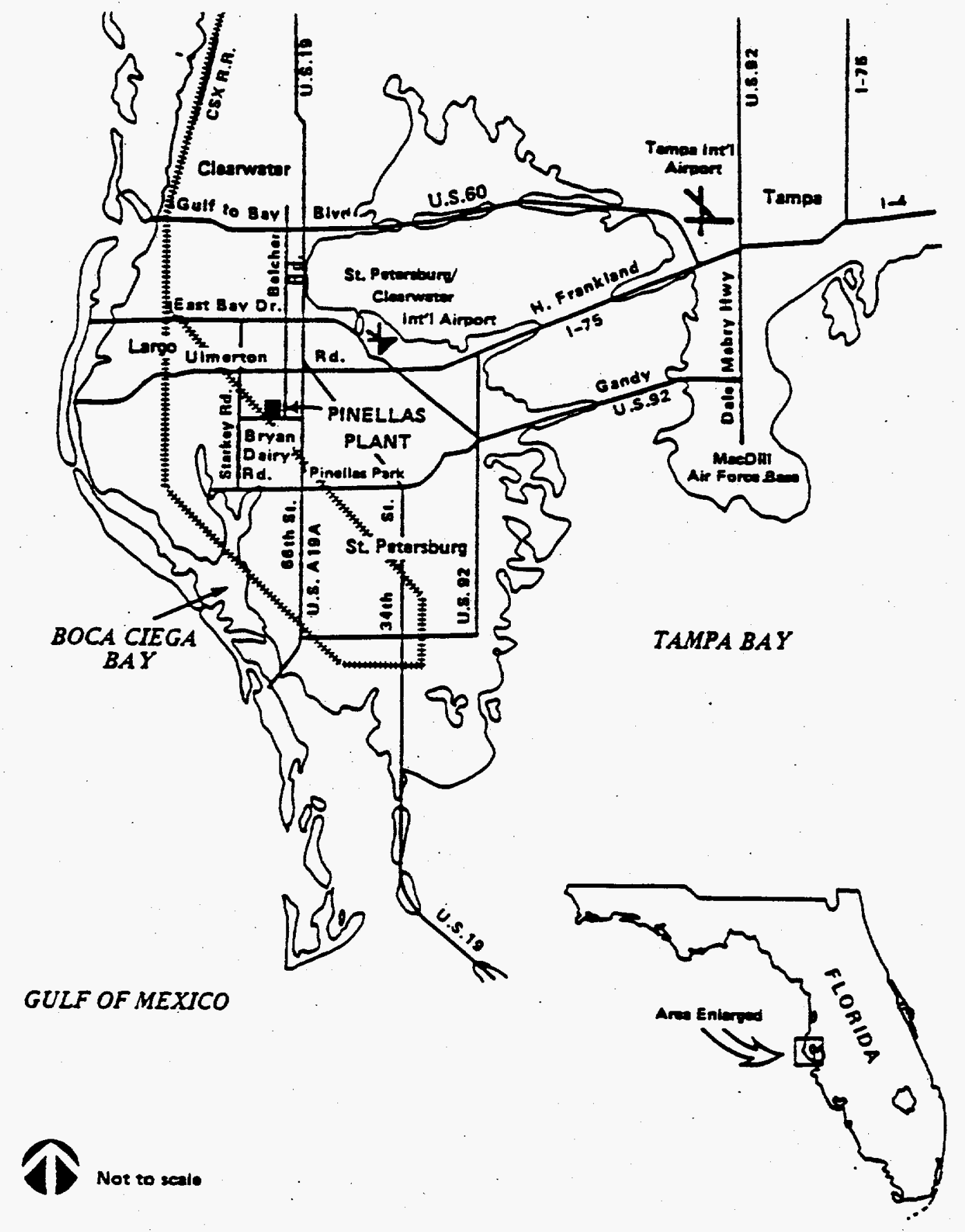

FIGURE 4.2. Location of the Pinellas Plant 


\section{TABLE 4.6. Pinellas Plant Average Local Climatology ${ }^{(a, b)}$}

Tampa Bay International Airport, Tampa Bay, Florida

Elevation:

Latitude:

Annual mean air temp:

Anemometer height:

Mean annual wind speed:

Fastest 1-min wind speed:

Annual precipitation:

Precipitation days:

Thunderstorms freq:

Avg morning mixing ht:

Avg afternoon mixing ht:

Topsoil moisture capacity:
$6 \mathrm{~m}$

$27.97^{\circ} \mathrm{N}$

$72.0^{\circ} \mathrm{F}$

$6.7 \mathrm{~m}$

$9 \mathrm{mph}$

$67 \mathrm{mph}$

46.7 in.

$197 \mathrm{yr}^{-1}$

$87 \mathrm{yr}^{-1}$

$700 \mathrm{~m}$

$1300 \mathrm{~m}$

$0.1 \mathrm{~cm}$

\begin{tabular}{|c|c|c|c|c|c|c|c|}
\hline \multirow[b]{2}{*}{ Month } & \multicolumn{5}{|c|}{ Monthly Averages } & \multicolumn{2}{|c|}{ Daily RH } \\
\hline & $\begin{array}{c}\text { Temp. } \\
\left({ }^{\circ} \mathbf{F}\right)\end{array}$ & $\begin{array}{l}\text { Precip. } \\
\text { (inches) }\end{array}$ & Wind Speed (mph) & $\begin{array}{c}\text { Cloud Cover } \\
\text { (tenths) }\end{array}$ & $\begin{array}{l}\text { Precip. } \\
\text { Days (\#) }\end{array}$ & $\begin{array}{l}\operatorname{Max} \\
(\%)\end{array}$ & $\begin{array}{l}\text { Min } \\
(\%)\end{array}$ \\
\hline Jan & 60 & 2.17 & 8.7 & 5.6 & 6.4 & 86 & 59 \\
\hline Feb & 61 & 3.04 & 9.3 & 5.5 & 6.9 & 85 & 56 \\
\hline Mar & 66 & 3.46 & 9.6 & 5.4 & 6.8 & 86 & 55 \\
\hline Apr & 72 & 1.82 & 9.4 & 4.9 & 4.7 & 87 & 51 \\
\hline May & 77 & 3.38 & 8.8 & 5.2 & 6.3 & 86 & 52 \\
\hline Jun & 81 & 5.29 & 8.1 & 6.1 & 11.6 & 87 & 60 \\
\hline Jul & 82 & 7.35 & 7.3 & 6.7 & 15.7 & 88 & 63 \\
\hline Aug & 82 & 7.64 & 7.1 & 6.6 & 16.8 & 91 & 64 \\
\hline Sep & 81 & 6.23 & 7.9 & 6.4 & 13.0 & 91 & 62 \\
\hline Oct & 74 & 2.34 & 8.6 & 5.2 & 7.0 & 89 & 57 \\
\hline Nov & 67 & 1.87 & 8.5 & 5.0 & 5.3 & 88 & 57 \\
\hline Dec & 61 & 2.14 & 8.6 & 5.6 & 6.4 & 87 & 59 \\
\hline
\end{tabular}

(a) Meteorological parameters are presented using the units with which they are routinely measured (e.g., temperature in ${ }^{\circ} \mathrm{F}$, wind speed in $\mathrm{mph}$ ). Temperature and precipitation averages are based on a 30-year climatologically representative period $(1951-1980)$. Other averages are based on 26 to 47 years of data.

(b) MEPAS Parameters: Climatic region index: 5

Precipitation-evaporation index: 95

Soil cons. serv. curve number: $\mathbf{5 0}$

Surficial Aquifer flow to the west and east and in places recharges the Upper

Floridian. Detailed geohydrologic data are presented in Table 4.7, and exposure/receptor data are presented in Table 4.8. 
TABLE 4.7. Geohydrological Data for the Pinellas Plant

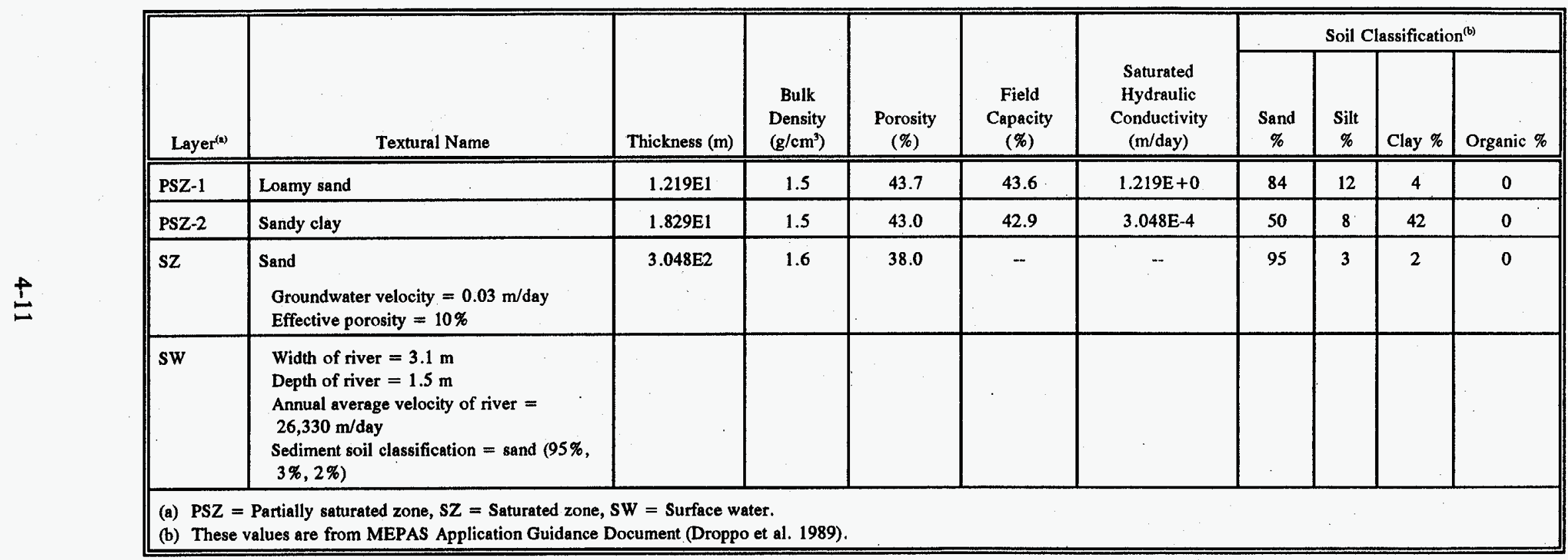


TABLE 4.8. Exposure Data for the Pinellas Plant

\begin{tabular}{|c|c|c|c|c|c|c|c|c|c|c|c|}
\hline $\begin{array}{c}\text { Receptor } \\
\text { Name }\end{array}$ & $\begin{array}{c}\text { Drinking Water } \\
\text { Population } \\
\end{array}$ & $\begin{array}{c}\text { Distance to } \\
\text { Receptor (m) }\end{array}$ & $\begin{array}{c}\text { Leafy } \\
\text { Vegetable } \\
(\mathrm{kg} / \mathrm{yr}) \\
\end{array}$ & $\begin{array}{c}\text { Other } \\
\text { Vegetables } \\
\text { (kg/yr) }\end{array}$ & $\begin{array}{c}\text { Milk } \\
\text { (kg/yr) }\end{array}$ & $\begin{array}{c}\text { Meat } \\
(\mathrm{kg} / \mathrm{yr}) \\
\end{array}$ & $\begin{array}{l}\text { Finfish } \\
(\mathrm{kg} / \mathrm{yr})\end{array}$ & $\begin{array}{c}\text { Shellfish } \\
(\mathrm{kg} / \mathrm{yr})\end{array}$ & $\begin{array}{l}\text { Recreation } \\
\text { Population } \\
\end{array}$ & $\begin{array}{c}\text { Discharge } \\
\text { Rate }\left(\mathrm{m}^{3} / \mathrm{day}\right)\end{array}$ & $\begin{array}{l}\text { Exposure } \\
\text { Routes for } \\
\text { Receptor } \\
\end{array}$ \\
\hline Well \#1 & 409 & 1,321 & $0.00 \mathrm{E}+00$ & $0.00 \mathrm{E}+00$ & $0.00 \mathrm{E}+00$ & $0.00 \mathrm{E}+00$ & - & - & - & -- & $\mathrm{GW}(\mathrm{E} 1, \mathrm{E} 2)$ \\
\hline Well $\# 2$ & 415 & 2,642 & $0.00 E+00$ & $0.00 \mathrm{E}+\infty 0$ & $0.00 \mathrm{E}+00$ & $0.00 E+\infty 0$ & - & -- & -- & - & $G W(E 1, E 2)$ \\
\hline Well \#3 & 15 & 3,603 & $0.00 \mathrm{E}+\infty$ & $0.00 \mathrm{E}+00$ & $1.03 E+04$ & $0.00 E+00$ & - & -- & - & - & $\begin{array}{c}\text { GW(E1,E2, } \\
\text { E5) }\end{array}$ \\
\hline Well \#4 & 469 & 5,044 & $0.00 \mathrm{E}+00$ & $0.00 \mathrm{E}+\infty$ & $5.07 \mathrm{E}+03$ & $0.00 \mathrm{E}+00$ & - & - & - & -- & $\begin{array}{c}\text { GW(E1,E2, } \\
\text { E5) } \\
\end{array}$ \\
\hline Well \#6 & 27 & 6,996 & $0.00 \mathrm{E}+\infty$ & $0.00 \mathrm{E}+00$ & $0.00 \mathrm{E}+00$ & $0.00 \mathrm{E}+00$ & - & -- & -. & - & $\mathrm{GW}(\mathrm{E} 1, \mathrm{E} 2)$ \\
\hline Well \#8 & 6 & 10,570 & $0.00 \mathrm{E}+00$ & $0.00 \mathrm{E}+\infty 0$ & $0.00 E+00$ & $0.00 E+00$ & - & -. & -- & -- & $\mathrm{GW}(\mathrm{E} 1, \mathrm{E} 2)$ \\
\hline Well \#10 & 6 & 14,170 & $0.00 \mathrm{E}+00$ & $0.00 \mathrm{E}+00$ & $0.00 \mathrm{E}+00$ & $0.00 \mathrm{E}+00$ & - & -- & - & -- & $\mathbf{G W}(\mathrm{E} 1, \mathrm{E} 2)$ \\
\hline Tampa Bay & 0 & 18,930 & $0.00 \mathrm{E}+00$ & $0.00 \mathrm{E}+00$ & $0.00 \mathrm{E}+00$ & $0.00 E+00$ & $5.17 \mathrm{E}+06$ & $3.23 \mathrm{E}+05$ & $1,544,415$ & $8.76 \mathrm{E}+08$ & $\mathrm{sW}(\mathrm{E} 2, \mathrm{E} 7, \mathrm{E} 8)$ \\
\hline \multicolumn{12}{|c|}{ Key for Exposure Routes } \\
\hline \multicolumn{12}{|c|}{$\begin{array}{l}\text { GW-E1 }=\text { GW } \rightarrow \text { Ingestion } \\
\text { GW-E2 }=\mathrm{GW} \rightarrow \text { Bathing/showering } \\
\text { GW-E5 }=\mathrm{GW} \rightarrow \text { Irrigation } \rightarrow \text { Animals } \rightarrow \text { Ingestion } \\
\text { SW-E2 }=\mathrm{SW} \rightarrow \text { Fish/Shellfish } \rightarrow \text { Ingestion } \\
\text { SW-E7 }=\mathrm{SW} \rightarrow \text { Recreation } \rightarrow \text { External Exposure } \\
\text { SW-E8 }=\mathbf{S W} \rightarrow \text { Recreation } \rightarrow \text { Ingestion }\end{array}$} \\
\hline
\end{tabular}


Within a few kilometers of the Pinellas Plant, the local population is on the order of a hundred thousand people. Within $80 \mathrm{~km}(50 \mathrm{mi})$ of the facility, the population is on the order of one million people. Detailed population data are presented in Table 4.9, and data on the distribution of agricultural products are presented in Table 4.10 .

\subsection{HANFORD RESERVATION}

The Hanford Site has an area of $560 \mathrm{mi}^{2}$ and is located in southcentral Washington State, a few miles north of Richland, Washington (Figure 4.3). There are 11 major operating areas scattered across a site that is generally characterized by gently rolling and flat topography. Natural vegetation consists of desert shrubs and grasses. Rattlesnake Mountain, Gable Butte, and Gable Mountain are significant terrain features located partly or completely within the Site. The Columbia River flows through the site and forms part of Hanford's eastern boundary. Except for the residential and some industrial development to the south of the Hanford Site, surrounding areas are primarily agricultural or undeveloped.

The climate of the region can be categorized as being of the semiarid type, a climate characteristic of the intermountain regions of the western states (see Table 4.11 for detailed climatic information). Precipitation is on the order of six inches per year. Meteorological data are obtained from onsite measurements in the Hanford Meteorology Station. Site winds are characterized using joint frequency distributions.

The Columbia and Yakima Rivers and several man-made ponds are the only significant surface water features located on or near the Site. Both confined and unconfined aquifers are present beneath the Hanford Site. The confined 
TABLE 4.9. Pinellas Plant Population Distribution for Atmospheric Pathway

Inhalation Population $=1,942,608$

\begin{tabular}{|l|r|r|r|r|r|r|r|r|r|r||}
\hline \multirow{2}{*}{ Direction } & \multicolumn{10}{|c|}{ Distance from Site $(\mathrm{km})$} \\
\cline { 2 - 14 } & 1.6 & 3.2 & 4.9 & 6.5 & 8.1 & 16.1 & 32.3 & 48.4 & 64.5 & 80.1 \\
\hline \hline N & 369 & 653 & 2800 & 5504 & 6213 & 49382 & 57152 & 81870 & 35693 & 2254 \\
\hline NNE & 1125 & 1000 & 2500 & 8231 & 1000 & 21056 & 10905 & 7401 & 10733 & 21909 \\
\hline NE & 1565 & 1000 & 1727 & 2000 & 500 & 0 & 59311 & 66893 & 8774 & 38229 \\
\hline ENE & 255 & 1000 & 752 & 1220 & 500 & 2546 & 139681 & 168184 & 30876 & 54623 \\
\hline E & 714 & 900 & 600 & 1431 & 300 & 5966 & 53458 & 61150 & 29043 & 36657 \\
\hline ESE & 27 & 850 & 2500 & 6819 & 1858 & 43665 & 4822 & 19815 & 2692 & 299 \\
\hline SE & 11 & 900 & 3000 & 6331 & 6000 & 67451 & 24017 & 6866 & 1727 & 197 \\
\hline SSE & 568 & 711 & 3492 & 4513 & 8176 & 70640 & 31827 & 69631 & 95142 & 100174 \\
\hline S & 519 & 3131 & 1000 & 3431 & 8669 & 31425 & 6486 & 8903 & 4717 & 0 \\
\hline SSW & 508 & 7000 & 1251 & 1945 & 5831 & 5069 & 0 & 0 & 0 & 0 \\
\hline SW & 0 & 1000 & 800 & 5951 & 5055 & 3307 & 0 & 0 & 0 & 0 \\
\hline WSW & 148 & 400 & 3209 & 4699 & 5917 & 8845 & 0 & 0 & 0 & 0 \\
\hline W & 433 & 1500 & 3941 & 1962 & 5550 & 8557 & 0 & 0 & 0 & 0 \\
\hline WNW & 289 & 1000 & 5356 & 3155 & 8454 & 5431 & 0 & 0 & 0 & 0 \\
\hline NW & 8 & 250 & 5299 & 2835 & 8878 & 7646 & 0 & 0 & 0 & 0 \\
\hline NNW & 42 & 176 & 3337 & 3531 & 8306 & 41880 & 3250 & 0 & 0 & 0 \\
\hline
\end{tabular}


TABLE 4.10. Distribution of Agriculture Products Around the Pinellas Plant

\begin{tabular}{|l|c|c|c|c|c|c||}
\hline \multicolumn{1}{|c|}{ Receptor Name } & Direction & $\begin{array}{c}\text { Distance } \\
(\mathrm{km})\end{array}$ & $\begin{array}{c}\text { Leafy } \\
\text { Vegetables } \\
(\mathrm{kg} / \mathrm{yr})\end{array}$ & $\begin{array}{c}\text { Other } \\
\text { Vegetables } \\
(\mathrm{kg} / \mathrm{yr})\end{array}$ & $\begin{array}{c}\text { Meat } \\
(\mathrm{kg} / \mathrm{yr})\end{array}$ & $\begin{array}{c}\text { Milk } \\
(\mathrm{kg} / \mathrm{yr})\end{array}$ \\
\hline \hline Hardee County & ESE & 76.6 & $0.00 \mathrm{E}+00$ & $2.70 \mathrm{E}+07$ & $1.91 \mathrm{E}+05$ & $8.95 \mathrm{E}+05$ \\
\hline Hernando County & NNE & 74.3 & $0.00 \mathrm{E}+00$ & $6.04 \mathrm{E}+05$ & $1.04 \mathrm{E}+06$ & $2.62 \mathrm{E}+06$ \\
\hline Hillsborough County & E & 50.3 & $3.70 \mathrm{E}+06$ & $4.06 \mathrm{E}+08$ & $8.44 \mathrm{E}+06$ & $8.39 \mathrm{E}+07$ \\
\hline Manatee County & SE & 57.1 & $5.50 \mathrm{E}+06$ & $3.23 \mathrm{E}+08$ & $2.97 \mathrm{E}+06$ & $2.69 \mathrm{E}+07$ \\
\hline Pasco County & NE & 54.9 & $0.00 \mathrm{E}+00$ & $2.20 \mathrm{E}+05$ & $4.71 \mathrm{E}+06$ & $2.95 \mathrm{E}+07$ \\
\hline Pinellas County & N & 28.9 & $0.00 \mathrm{E}+00$ & $5.47 \mathrm{E}+06$ & $1.56 \mathrm{E}+05$ & $5.61 \mathrm{E}+06$ \\
\hline Polk County & E & 73.1 & $0.00 \mathrm{E}+00$ & $1.57 \mathrm{E}+08$ & $8.38 \mathrm{E}+05$ & $1.86 \mathrm{E}+06$ \\
\hline Sarasota County & SSE & 69.7 & $3.62 \mathrm{E}+06$ & $2.90 \mathrm{E}+07$ & $6.84 \mathrm{E}+05$ & $1.60 \mathrm{E}+06$ \\
\hline
\end{tabular}




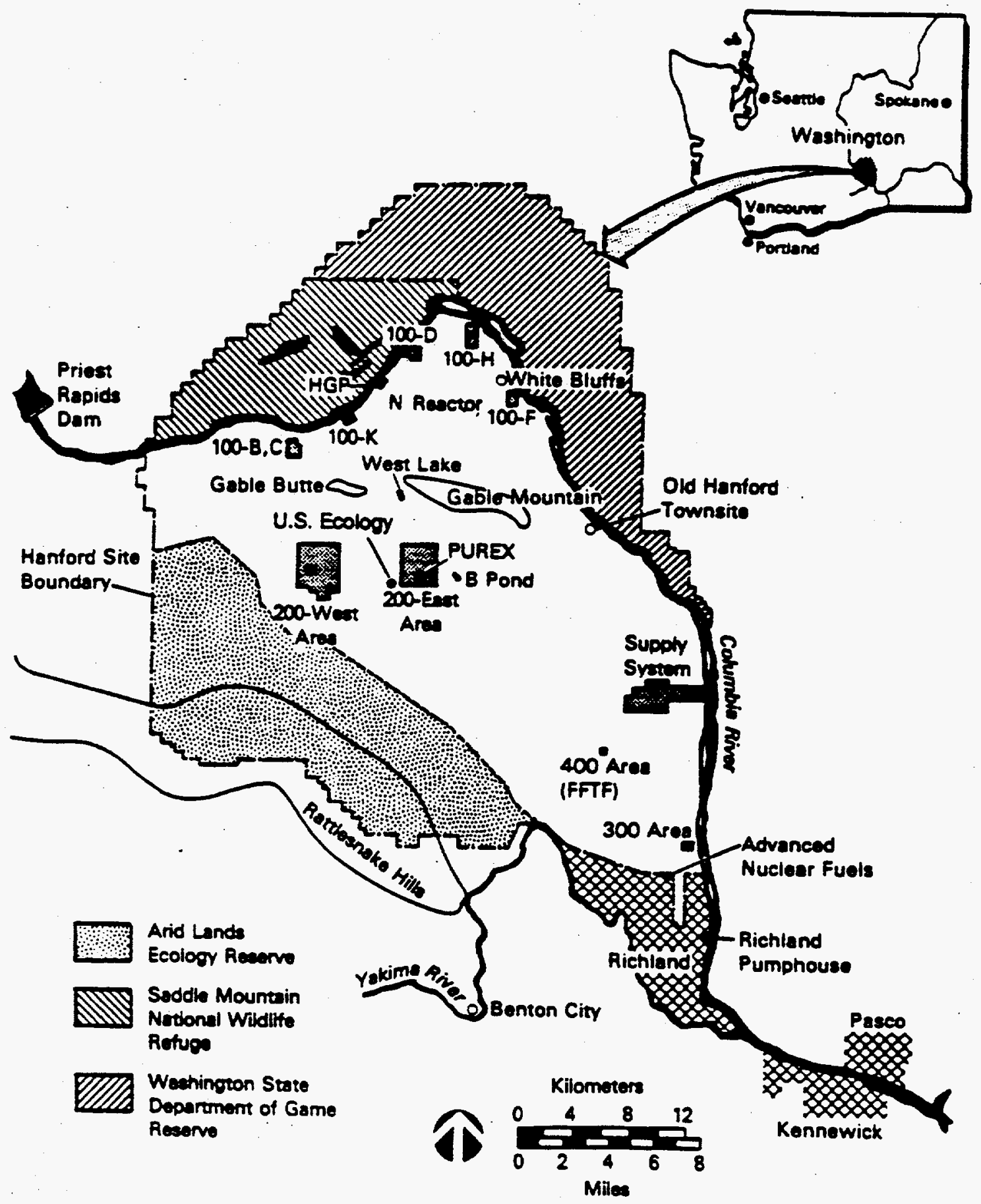

FIGURE 4.3. Location of the Hanford Site 
TABLE 4.11. Hanford Reservation Average Local Climatology

Hanford Meteorology Station, Hanford, Washington

Station Elevation:

Anemometer Height:

$223 \mathrm{~m}$

Station Latitude:

$7.0 \mathrm{~m}$

Topsoil Moisture Capacity: $0.3 \mathrm{~cm}$

SCS Curve Number:

62

\begin{tabular}{|l|c|c|c|c|c|c|c||}
\hline Month & $\begin{array}{c}\text { Temp. } \\
\left({ }^{\circ} \mathrm{F}\right)\end{array}$ & $\begin{array}{c}\text { Precip. } \\
\text { (inches) }\end{array}$ & $\begin{array}{c}\text { Wind } \\
\text { Speed } \\
(\mathrm{mph})\end{array}$ & $\begin{array}{c}\text { Cloud } \\
\text { Cover } \\
\text { (tenths) }\end{array}$ & $\begin{array}{c}\text { Precip. } \\
\text { Days (\#) }\end{array}$ & $\begin{array}{c}\text { Maximum } \\
\text { Humidity } \\
(\%)\end{array}$ & $\begin{array}{c}\text { Minimum } \\
\text { Humidity } \\
(\%)\end{array}$ \\
\hline Jan & 29.0 & 0.92 & 6.4 & 7.9 & 3.0 & 89 & 60 \\
\hline Feb & 36.0 & 0.60 & 7.1 & 7.6 & 2.0 & 87 & 54 \\
\hline Mar & 45.0 & 0.37 & 8.5 & 6.8 & 2.0 & 66 & 44 \\
\hline Apr & 53.0 & 0.39 & 9.0 & 6.4 & 1.0 & 65 & 37 \\
\hline May & 62.0 & 0.48 & 8.9 & 5.9 & 2.0 & 62 & 31 \\
\hline Jun & 69.0 & 0.54 & 9.2 & 5.3 & 2.0 & 54 & 30 \\
\hline Jul & 76.0 & 0.15 & 8.7 & 2.9 & 1.0 & 41 & 22 \\
\hline Aug & 74.0 & 0.24 & 8.0 & 3.4 & 1.0 & 48 & 25 \\
\hline Sep & 65.0 & 0.31 & 7.5 & 4.1 & 1.0 & 56 & 33 \\
\hline Oct & 53.0 & 0.56 & 6.6 & 5.8 & 2.0 & 74 & 43 \\
\hline Nov & 40.0 & 0.85 & 6.1 & 7.7 & 3.0 & 89 & 63 \\
\hline Dec & 33.0 & 0.89 & 6.1 & 8.1 & 3.0 & 91 & 69 \\
\hline
\end{tabular}

aquifers are found primarily in sediments between the Columbia River Basalt flows. The relatively shallow, unconfined aquifer consists of the Ringold Formation and glaciofluvial sediments, as well as some more recent alluvial sediments in areas adjacent to the Columbia River. Natural recharge to the unconfined system comes from precipitation and runoff from mountains near the western boundary of the Site. The Yakima River also recharges the unconfined aquifer as it flows along the southwest boundary of the Site. The unconfined system receives little recharge from precipitation falling over most of the 
Hanford Site; however, artificial recharge from liquid waste disposal has produced significant changes in local groundwater flow. Detailed geohydrologic data are presented in Table 4.12 and exposure/receptor data are presented in Table 4.13.

Within a few miles of Hanford, the local population is on the order of about ten thousand people. Within 50 miles of the facility, the population is on the order of two hundred thousand people. Detailed population data are presented in Table 4.14, and data on the distribution of agricultural products are presented in Table 4.15.

\subsection{Los Alamos National Laboratory}

The Los Alamos National Laboratory (LANL) occupies $113 \mathrm{~km}^{2}\left(44 \mathrm{mi}^{2}\right)$ located approximately $40 \mathrm{~km}(25 \mathrm{mi})$ northwest of Santa Fe, New Mexico (Figure 4.4). The site is located on the Pajarito Plateau between the Jemez Mountains and the Rio Grande Valley. The towns of Los Alamos and White Rock are adjacent to the site.

The climate of the region can be categorized as being of the semiarid type, a climate characteristic of the intermountain regions of the western states (see Table 4.16 for detailed climatic information). Meteorological data are obtained from onsite measurements and from measurements at the National Weather Service's Albuquerque station in Albuquerque, New Mexico. Precipitation onsite is on the order of $46 \mathrm{~cm}$ (18 in.) per year, compared with about $21 \mathrm{~cm}$ (8 in.) in Albuquerque. Site winds are characterized using joint frequency distributions obtained from measurements at LANL.

Sixteen drainage areas pass through or start within the site. Stream flow is intermittent; several spring fed streams have insufficient water to maintain flows 
TABLE 4.12. Geohydrologic Data for the Hanford Reservation

\begin{tabular}{|c|c|c|c|c|c|c|c|c|c|c|}
\hline \multirow[b]{2}{*}{ Layer (a) } & \multirow[b]{2}{*}{ Textural Name } & \multirow[b]{2}{*}{ Thickness (m) } & \multirow[b]{2}{*}{$\begin{array}{c}\text { Bulk } \\
\text { Density } \\
\left(\mathrm{g} / \mathrm{cm}^{3}\right)\end{array}$} & \multirow[b]{2}{*}{$\begin{array}{l}\text { Total } \\
\text { Porosity } \\
\text { (\%) }\end{array}$} & \multirow[b]{2}{*}{$\begin{array}{l}\text { Field } \\
\text { Capacity } \\
(\%)\end{array}$} & \multirow[b]{2}{*}{$\begin{array}{l}\text { Saturated } \\
\text { Hydraulic } \\
\text { Conductivity } \\
\text { (m/day) }\end{array}$} & \multicolumn{4}{|c|}{ Soil Classification ${ }^{(b)}$} \\
\hline & & & & & & & $\begin{array}{c}\text { Sand } \\
\%\end{array}$ & $\begin{array}{c}\text { Silt } \\
\%\end{array}$ & Clay \% & Organic \% \\
\hline PSZ-1 & Sandy clay loam & $1.520 \mathrm{E} 2$ & 1.6 & 39.8 & 24.0 & .4,900E-1 & 60 & 14 & 26 & $\mathbf{0}$ \\
\hline PSZ-2 & Sandy & $2.500 \mathrm{E} 2$ & 1.4 & 43.0 & 29.0 & $8.800 \mathrm{E} 2$ & 94 & 4 & 2 & $\mathbf{0}$ \\
\hline sz & $\begin{array}{l}\text { Loamy sand } \\
\text { Groundwater velocity }=0.6 \mathrm{~m} / \text { day } \\
\text { Effective porosity }=25 \% \\
\text { Depth of site below water table }=0.0 \mathrm{~m}\end{array}$ & $1.788 \mathrm{E} 2$ & 1.5 & 26.0 & -- & - & 84 & 12 & 4 & $\mathbf{0}$ \\
\hline sw & $\begin{array}{l}\text { Width of river }=457.0 \mathrm{~m} \\
\text { Depth of river }=7.6 \mathrm{~m} \\
\text { Annual average velocity of river }= \\
84,270 \mathrm{~m} / \text { day } \\
\text { Sediment soil classification }=\text { loamy } \\
\text { sand }(84 \%, 12 \%, 4 \%)\end{array}$ & & & & & & & & & \\
\hline
\end{tabular}


TABLE 4.13. Exposure Data for the Hanford Reservation

\begin{tabular}{|c|c|c|c|c|c|c|c|c|c|c|c|}
\hline $\begin{array}{l}\text { Receptor } \\
\text { Name }\end{array}$ & $\begin{array}{c}\text { Drinking Water } \\
\text { Population }\end{array}$ & $\begin{array}{l}\text { Distance to } \\
\text { Receptor (m) }\end{array}$ & $\begin{array}{c}\text { Leafy } \\
\text { Vegetable } \\
(\mathrm{kg} / \mathrm{yr})\end{array}$ & $\begin{array}{c}\text { Other } \\
\text { Vegetables } \\
(\mathrm{kg} / \mathrm{yr})\end{array}$ & $\begin{array}{c}\text { Milk } \\
(\mathrm{kg} / \mathrm{yr})\end{array}$ & $\begin{array}{c}\text { Meat } \\
(\mathrm{kg} / \mathrm{yr})\end{array}$ & $\begin{array}{l}\text { Finfish } \\
(\mathbf{k g} / \mathbf{y r}) \\
\end{array}$ & $\begin{array}{c}\begin{array}{c}\text { Shellfish } \\
(\mathrm{kg} / \mathrm{yr})\end{array} \\
\end{array}$ & $\begin{array}{l}\text { Recreation } \\
\text { Population } \\
\end{array}$ & $\begin{array}{c}\text { Discharge } \\
\text { Rate }\left(\mathrm{m}^{3} / \mathrm{day}\right)\end{array}$ & $\begin{array}{c}\text { Exposure } \\
\text { Routes for } \\
\text { Receptor }\end{array}$ \\
\hline $\begin{array}{l}\text { Farm Well } \\
\text { (GW) }\end{array}$ & 4 & 75 & $0.00 \mathrm{E}+00$ & $0.00 \mathrm{E}+00$ & $0.00 \mathrm{E}+00$ & $0.00 \mathrm{E}+00$ & -- & -- & -- & - & $\begin{array}{l}\text { GW(E1,E2, } \\
\text { E5) }\end{array}$ \\
\hline $\begin{array}{l}\text { Richland } \\
\text { Intake (SW) }\end{array}$ & 33,564 & 6,000 & $0.00 \mathrm{E}+00$ & $0.00 \mathrm{E}+00$ & $0.00 \mathrm{E}+00$ & $0.00 \mathrm{E}+00$ & $0.00 \mathrm{E}+00$ & $0.00 E+00$ & 0 & $3.1 \mathrm{E}+08$ & SW(E1,E6) \\
\hline 300 Area & 669 & - & $0.00 \mathrm{E}+00$ & $0.00 \mathrm{E}+00$ & $0.00 \mathrm{E}+00$ & $0.00 \mathrm{E}+00$ & $0.00 \mathrm{E}+00$ & $0.00 \mathrm{E}+00$ & 0 & $3.1 \mathrm{E}+08$ & sW(E1,E6) \\
\hline Franklin Co. & 0 & - & $0.00 \mathrm{E}+00$ & $5.80 \mathrm{E}+05$ & $8.40 \mathrm{E}+03$ & $2.80 \mathrm{E}+04$ & $0.00 \mathrm{E}+00$ & $0.00 \mathrm{E}+00$ & 0 & $3.0 \mathrm{E}+08$ & $\mathrm{SW}(\mathrm{E} 3, \mathrm{E} 4, \mathrm{E} 5)$ \\
\hline Kennewick & 320,000 & - & $0.00 \mathrm{E}+00$ & $0.00 \mathrm{E}+00$ & $0.00 \mathrm{E}+00$ & $0.00 \mathrm{E}+00$ & $0.00 \mathrm{E}+00$ & $0.00 \mathrm{E}+00$ & 0 & $3.1 E+08$ & SW(E1,E6) \\
\hline Pasco & 170,000 & $\cdots$ & $0.00 \mathrm{E}+00$ & $0.00 \mathrm{E}+00$ & $0.00 \mathrm{E}+00$ & $0.00 \mathrm{E}+00$ & $0.00 \mathrm{E}+00$ & $0.00 \mathrm{E}+00$ & 0 & $3.1 E+08$ & SW(E1,E6) \\
\hline Benton Co. & 0 & - & $0.00 \mathrm{E}+00$ & $1.40 \mathrm{E}+08$ & $1.20 \mathrm{E}+06$ & $2.10 \mathrm{E}+06$ & $0.00 \mathrm{E}+00$ & $0.00 \mathrm{E}+00$ & 0 & $4.4 \mathrm{E}+08$ & $\mathrm{SW}(\mathrm{E} 3, \mathrm{E} 4, \mathrm{E} 5)$ \\
\hline Walla Walla & 0 & -- & $1.60 \mathrm{E}+05$ & $8.30 \mathrm{E}+06$ & $1.80 \mathrm{E}+05$ & $2.80 \mathrm{E}+05$ & $0.00 \mathrm{E}+00$ & $0.00 \mathrm{E}+00$ & 0 & $4.4 \mathrm{E}+08$ & SW(E3,E4,E5) \\
\hline \multicolumn{12}{|c|}{$\begin{array}{l}\text { Key for Exposure Routes: } \\
\text { OW-E1 }=\mathbf{G W} \rightarrow \text { Ingestion } \\
\text { GW-E2 }=\mathbf{G W} \rightarrow \text { Bathing/showering } \\
\text { GW-E5 }=\mathbf{G W} \rightarrow \text { Animals } \rightarrow \text { Ingestion } \\
\text { SW-E1 }=\mathbf{S W} \rightarrow \text { Ingestion } \\
\text { SW-E2 }=\mathbf{S W} \rightarrow \text { Fish/Shellfish } \rightarrow \text { Ingestion } \\
\text { SW-E6 }=\mathrm{SW} \rightarrow \text { Bathing/Showering } \\
\text { SW-E7 }=\mathbf{S W} \rightarrow \text { Recreation } \rightarrow \text { External exposure } \\
\text { SW-E8 }=\mathbf{S W} \rightarrow \text { Recreation } \rightarrow \text { Ingestion }\end{array}$} \\
\hline
\end{tabular}


TABLE 4.14. Hanford Reservation Population Distribution for Atmospheric Pathway

Inhalation Population $=340,943$

\begin{tabular}{||l|r|r|r|r|r|r|r|r|r|r||}
\hline \multirow{2}{*}{ Direction } & \multicolumn{10}{|c|}{ Distance from Site $(\mathrm{km})$} \\
\cline { 2 - 11 } & 1.6 & 3.2 & 4.9 & 6.5 & 8.1 & 16.1 & 32.3 & 48.4 & 64.5 & 80.1 \\
\hline \hline N & 0 & 0 & 0 & 0 & 0 & 0 & 174 & 1124 & 772 & 1957 \\
\hline NNE & 0 & 0 & 0 & 0 & 0 & 0 & 92 & 656 & 5547 & 14822 \\
\hline NE & 0 & 0 & 0 & 0 & 0 & 0 & 262 & 5930 & 2963 & 596 \\
\hline ENE & 0 & 0 & 0 & 0 & 0 & 0 & 235 & 773 & 2366 & 435 \\
\hline E & 0 & 0 & 0 & 0 & 0 & 0 & 340 & 1329 & 1659 & 588 \\
\hline ESE & 0 & 0 & 0 & 0 & 0 & 0 & 283 & 1374 & 230 & 652 \\
\hline SE & 0 & 0 & 0 & 0 & 0 & 0 & 6757 & 48661 & 50519 & 3474 \\
\hline SSE & 0 & 0 & 0 & 0 & 0 & 0 & 1997 & 13161 & 2717 & 5218 \\
\hline S & 0 & 0 & 0 & 0 & 0 & 0 & 1532 & 1489 & 195 & 1799 \\
\hline SSW & 0 & 0 & 0 & 0 & 0 & 0 & 905 & 5283 & 652 & 129 \\
\hline SW & 0 & 0 & 0 & 0 & 0 & 0 & 1190 & 19786 & 2182 & 459 \\
\hline WSW & 0 & 0 & 0 & 0 & 0 & 0 & 1840 & 5063 & 15088 & 4573 \\
\hline W & 0 & 0 & 0 & 0 & 0 & 32 & 648 & 949 & 6874 & 78635 \\
\hline WNW & 0 & 0 & 0 & 0 & 0 & 73 & 444 & 802 & 833 & 2833 \\
\hline NW & 0 & 0 & 0 & 0 & 0 & 0 & 555 & 398 & 493 & 1454 \\
\hline NNW & 0 & 0 & 0 & 0 & 0 & 0 & 246 & 456 & 864 & 4521 \\
\hline
\end{tabular}


TABLE 4.15. Distribution of Agriculture Products Around the Reservation

\begin{tabular}{|l|c|c|c|c|c|c||}
\hline \hline Receptor Name & Direction & $\begin{array}{c}\text { Distance } \\
(\mathrm{km})\end{array}$ & $\begin{array}{c}\text { Leafy Vegetables } \\
(\mathrm{kg} / \mathrm{yr})\end{array}$ & $\begin{array}{c}\text { Other Vegetables } \\
(\mathrm{kg} / \mathrm{yr})\end{array}$ & $\begin{array}{c}\text { Meat } \\
(\mathrm{kg} / \mathrm{yr})\end{array}$ & $\begin{array}{c}\text { Milk } \\
(\mathrm{kg} / \mathrm{yr})\end{array}$ \\
\hline \hline Benton Co. & S & 35.0 & $0.00 \mathrm{E}+00$ & $1.10 \mathrm{E}+08$ & $4.20 \mathrm{E}+06$ & $7.40 \mathrm{E}+06$ \\
\hline Franklin Co. & SSE & 51.0 & $0.00 \mathrm{E}+00$ & $4.80 \mathrm{E}+07$ & $3.80 \mathrm{E}+06$ & $1.30 \mathrm{E}+07$ \\
\hline Walla Walla Co. & ESE & 77.0 & $1.20 \mathrm{E}+06$ & $3.50 \mathrm{E}+07$ & $1.40 \mathrm{E}+06$ & $2.20 \mathrm{E}+06$ \\
\hline Adams Co. & SE & 54.0 & $0.00 \mathrm{E}+00$ & $2.80 \mathrm{E}+07$ & $9.80 \mathrm{E}+05$ & $1.60 \mathrm{E}+06$ \\
\hline Grant Co. & N & 54.0 & $0.00 \mathrm{E}+00$ & $5.50 \mathrm{E}+07$ & $6.00 \mathrm{E}+06$ & $1.50 \mathrm{E}+07$ \\
\hline Kittitas Co. & NNW & 69.0 & $0.00 \mathrm{E}+00$ & $1.70 \mathrm{E}+06$ & $1.60 \mathrm{E}+06$ & $2.50 \mathrm{E}+06$ \\
\hline Klickitat Co. & SSW & 72.0 & $5.50 \mathrm{E}+04$ & $1.10 \mathrm{E}+06$ & $1.70 \mathrm{E}+05$ & $2.70 \mathrm{E}+05$ \\
\hline Yakima Co. & WSW & 51.0 & $3.80 \mathrm{E}+05$ & $2.02 \mathrm{E}+08$ & $6.00 \mathrm{E}+06$ & $2.60 \mathrm{E}+07$ \\
\hline
\end{tabular}




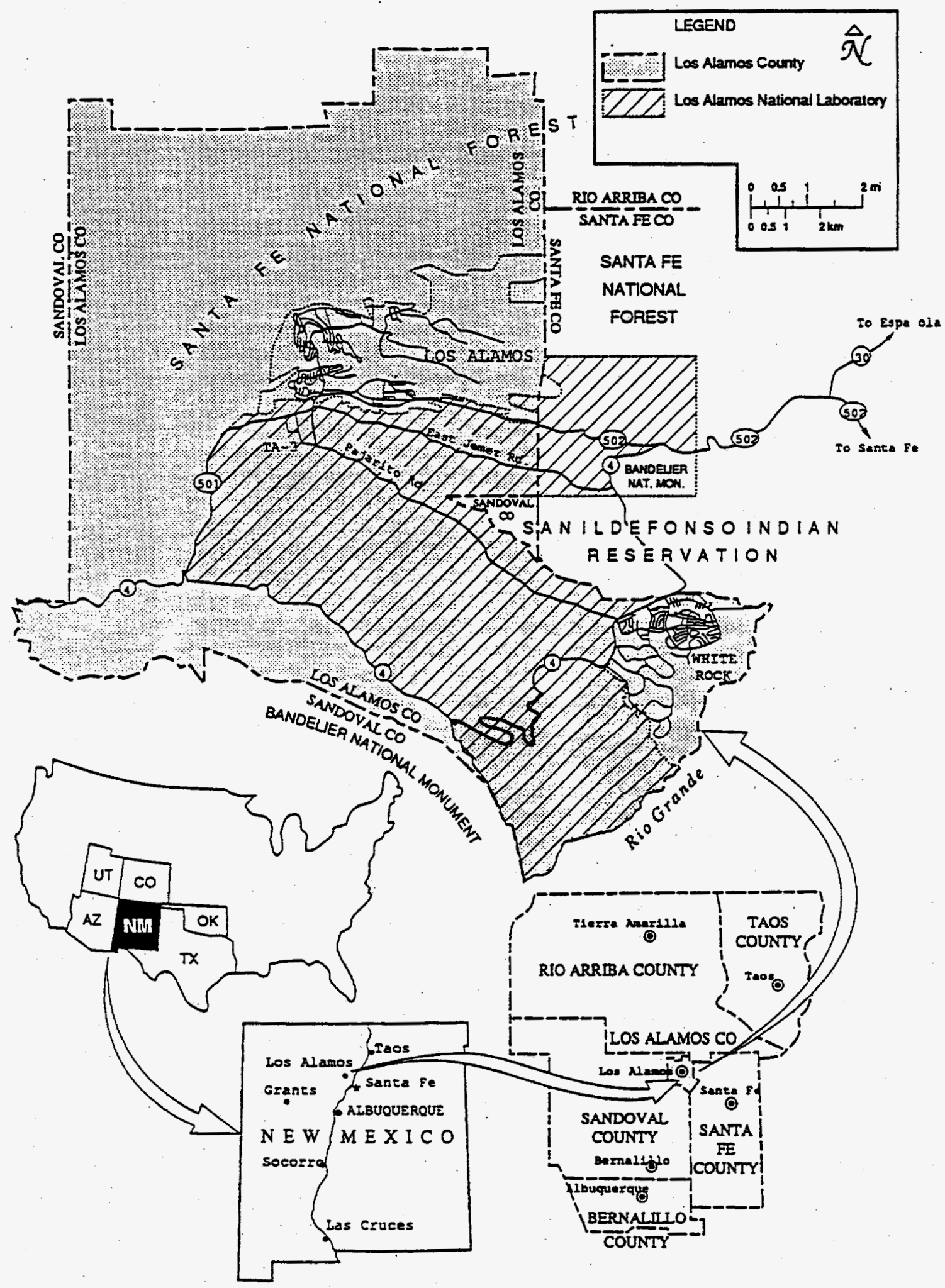

FIGURE 4.4. Location of the Los Alamos National Laboratory 


\section{TABLE 4.16. LANL Average Local Climatology ${ }^{(a, b)}$}

Albuquerque National Weather Station, Albuquerque, New Mexico

Elevation: $1,619 \mathrm{~m}$

Latitude: $35.05^{\circ} \mathrm{N}$

Los Alamos Meteorology Monitoring Site, Los Alamos, New Mexico

Elevation: $2,046 \mathrm{~m}$ Latitude: $38.25^{\circ} \mathrm{N}$
Annual Mean Air Temp:
$56.2^{\circ} \mathrm{F}^{(\mathrm{a})} / 48.0^{\circ} \mathrm{F}^{(\mathrm{b})}$
Anemometer Height:
$7.0 \mathrm{~m}^{(\mathrm{a}) / 11.0 \mathrm{~m}^{(\mathrm{b})}}$
Mean Annual Wind Speed:
$9 \mathrm{mph}^{(\mathrm{a})} / 7 \mathrm{mph}^{(\mathrm{b})}$
Fastest 1-Min Wind Speed:
$90 \mathrm{mph}^{(\mathrm{a})}$
Annual Precipitation:
$8.1 \mathrm{in}^{(\mathrm{a})} / 18.0 \mathrm{in} .^{(b)}$
Precipitation Days:
$60 \mathrm{yr}^{-1(a)} / 89 \mathrm{yr}^{-1(b)}$
Thunderstorms Freq:
$42 \mathrm{yr}^{-1}$
Avg Morning Mixing $\mathrm{Ht}$ :
$400 \mathrm{~m}$
Avg Afternoon Mixing Ht: $2600 \mathrm{~m}$
Topsoil Moisture Capacity: $3.0 \mathrm{~cm}$

\begin{tabular}{|c|c|c|c|c|c|c|c|}
\hline \multirow[b]{2}{*}{ Month } & \multicolumn{5}{|c|}{ Monthly Averages } & \multicolumn{2}{|c|}{ Daily RH } \\
\hline & $\begin{array}{l}\text { Temp. } \\
\left({ }^{\circ} \mathrm{F}\right)\end{array}$ & $\begin{array}{l}\text { Precip. } \\
\text { (inches) }\end{array}$ & Wind Speed (mph) & $\begin{array}{l}\text { Cloud Cover } \\
\text { (tenths) }\end{array}$ & $\begin{array}{l}\text { Precip. } \\
\text { Days (\#) }\end{array}$ & $\begin{array}{l}\operatorname{Max} \\
(\%)\end{array}$ & $\begin{array}{l}\text { Min } \\
(\%)\end{array}$ \\
\hline Jan & 35 & 0.41 & 8.0 & 4.8 & 4 & 71 & 40 \\
\hline Feb & 39 & 0.40 & 8.8 & 4.9 & 4 & 65 & 32 \\
\hline Mar & 46 & 0.52 & 10.1 & 5.1 & 5 & 56 & 24 \\
\hline Apr & 55 & 0.40 & 11.0 & 4.6 & 3 & 49 & 18 \\
\hline May & 64 & 0.46 & 10.5 & 4.2 & 4 & 48 & 18 \\
\hline Jun & 75 & 0.51 & 10.0 & 3.3 & 4 & 46 & 17 \\
\hline Jul & 79 & 1.30 & 9.1 & 4.5 & 9 & 60 & 27. \\
\hline Aug & 76 & 1.51 & 8.2 & 4.3 & 9 & 66 & 30 \\
\hline Sep & 69 & 0.85 & 8.6 & 3.6 & 6 & 62 & 31 \\
\hline Oct & 57 & 0.86 & 8.3 & 3.5 & 5 & 62 & 30 \\
\hline Nov & 44 & 0.38 & 7.9 & 4.0 & 4 & 66 & 36 \\
\hline Dec & 36 & 0.52 & 7.7 & 4.6 & 4 & 71 & 43 \\
\hline
\end{tabular}

(a) Meteorological parameters are presented using the units with which they are routinely measured (e.g., temperature in ${ }^{\circ} \mathrm{F}$, wind speed in $\mathrm{mph}$ ). Temperature and precipitation averages are based on a 30-year climatologically representative period (1951 - 1980). Other averages are based on 26 to 47 years of data.

(b) MEPAS Parameters: Climatic Region Index: 2

Precipitation-Evaporation Index: 46

Soil Cons. Serv. Curve Number: 30 
across the site. Runoff from heavy thunderstorms or snowmelt reaches the Rio Grande several times a year. The main aquifer is located within the Tesuque Formation that lies beneath the entire plateau and Rio Grande Valley. Depths to water below the mesa tops range from 180 to $365 \mathrm{~m}$ (600 to $1,200 \mathrm{ft}$ ). Detailed geohydrologic data are presented in Table 4.17 and exposure/receptor data are presented in Table 4.18.

Within a few kilometers of the LANL, the local population is about twenty thousand people. Within $80 \mathrm{~km}(50 \mathrm{mi})$ of the facility, the population is about one hundred thousand people. Detailed population data are presented in Table 4.19, and data on the distribution of agricultural products are presented in Table 4.20.

\subsection{MAYWOOD SITE (FUSRAP)}

The Maywood Site, ${ }^{(a)}$ which has been designated for inclusion in the Department of Energy's (DOE) Formerly Utilized Sites Remedial Action Program (FUSRAP), is located in Northwestern New Jersey, 12 miles (20 km) north-northwest of New York City. The site spans portions of the boroughs of Maywood and Lodi and the township of Rochelle Park, which lie in the suburban environs of the Bergen County-metropolitan New York City area (see Figure 4.5). The site consists largely of commercial buildings and properties and several residential neighborhoods that were contaminated by chemical/ industrial activity.

(a) U.S. Department of Energy (DOE). 1993. "Feasibility Study Environmental Impact Statement for the Maywood Site." Former Sites Restoration Division, DOE, Washington, D.C. 
TABLE 4.17. Geohydrologic Data for the LANL

\begin{tabular}{|c|c|c|c|c|c|c|c|c|c|c|}
\hline \multirow[b]{2}{*}{ Layer $^{(a)}$} & \multirow[b]{2}{*}{ Textural Name } & \multirow[b]{2}{*}{ Thickness (m) } & \multirow[b]{2}{*}{$\begin{array}{c}\text { Bulk } \\
\text { Density } \\
\left(\mathrm{g} / \mathrm{cm}^{3}\right)\end{array}$} & \multirow[b]{2}{*}{$\begin{array}{l}\text { Porosity } \\
\text { (\%) }\end{array}$} & \multirow[b]{2}{*}{$\begin{array}{c}\text { Field } \\
\text { Capacity } \\
(\%)\end{array}$} & \multirow[b]{2}{*}{$\begin{array}{c}\text { Saturated } \\
\text { Hydraulic } \\
\text { Conductivity } \\
\text { (m/day) }\end{array}$} & \multicolumn{4}{|c|}{ Soil Classification $^{(b)}$} \\
\hline & & & & & & & $\begin{array}{c}\text { Sand } \\
\%\end{array}$ & $\begin{array}{c}\text { Silt } \\
\%\end{array}$ & Clay \% & Organic $\%$ \\
\hline PSZ-1 & Sandy clay loam & $1.996 \mathrm{E} 2$ & 1.6 & 40.0 & 24.0 & $9.144 \mathrm{E}-02$ & 60 & 14 & 26 & $\mathbf{0}$ \\
\hline PSZ-2 & Sand & $1.981 \mathrm{E} 2$ & 1.6 & 38.0 & 9.0 & $6.096 \mathrm{E}+00$ & 95 & 3 & 2 & $\mathbf{0}$ \\
\hline \multirow[t]{2}{*}{ sz } & Silty loam & $9.144 \mathrm{E} 1$ & 1.4 & 46.3 & -- & -- & 25 & 63 & 12 & $\mathbf{0}$ \\
\hline & $\begin{array}{l}\text { Groundwater velocity }=0.31 \mathrm{~m} / \text { day } \\
\text { Effective porosity }=5 \%\end{array}$ & & & & & & & & & \\
\hline sw & $\begin{array}{l}\text { Width of river }=37 \mathrm{~m} \\
\text { Depth of river }=1.2 \mathrm{~m} \\
\text { Annual average velocity of river }= \\
100,000 \mathrm{~m} / \text { day } \\
\text { Sediment soil classification = loamy } \\
\text { sand }(84 \%, 12 \%, 4 \%)\end{array}$ & & & & & & & & & \\
\hline
\end{tabular}


TABLE 4.18. Exposure Data for the LANL

\begin{tabular}{|c|c|c|c|c|c|c|c|c|c|c|}
\hline Receptor Name & $\begin{array}{c}\text { Drinking Water } \\
\text { Population }\end{array}$ & $\begin{array}{c}\text { Distance to } \\
\text { Receptor }(\mathrm{m})\end{array}$ & $\begin{array}{c}\text { Leafy } \\
\text { Vegetable } \\
\text { (kg/yr) } \\
\end{array}$ & $\begin{array}{c}\text { Other } \\
\text { Vegetables } \\
\text { (kg/yr) }\end{array}$ & $\begin{array}{c}\text { Milk } \\
(\mathrm{kg} / \mathrm{yr})\end{array}$ & $\begin{array}{c}\text { Meat } \\
(\mathrm{kg} / \mathrm{yr})\end{array}$ & $\begin{array}{l}\text { Finfish } \\
(\mathrm{kg} / \mathrm{yr})\end{array}$ & $\begin{array}{c}\text { Shellfish } \\
(\mathrm{kg} / \mathrm{yr})\end{array}$ & $\begin{array}{l}\text { Recreation } \\
\text { Population } \\
\end{array}$ & $\begin{array}{l}\text { Exposure } \\
\text { Routes for } \\
\text { Receptor }\end{array}$ \\
\hline Rio Grande (SW) & $\mathbf{0}$ & 1,609 & 0.0 & 0.0 & 0.0 & 0.0 & $2.9 \mathrm{E}+05$ & 0.0 & 400,000 & SW(E2,E8) \\
\hline Bernalillo County (SW) & 0 & - & $7.6 \mathrm{E}+04$ & $6.4 \mathrm{E}+05$ & $1.9 E+06$ & $1.9 \mathrm{E}+07$ & 0.0 & 0.0 & -- & $\mathrm{SW}(\mathrm{E} 3, \mathrm{E} 4, \mathrm{E} 5)$ \\
\hline Sandoval County (SW) & 0 & - & $1.9 \mathrm{E}+05$ & $6.1 \mathrm{E}+05$ & $1.1 \mathrm{E}+06$ & 0.0 & 0.0 & 0.0 & -- & $\mathrm{SW}(\mathrm{E} 3, \mathrm{E} 4, \mathrm{ES})$ \\
\hline \multicolumn{11}{|l|}{ Key for Exposure Routes } \\
\hline \multicolumn{11}{|c|}{$\begin{array}{l}\text { SW-E2 }=\mathrm{SW} \rightarrow \text { Fish/Shellfish } \rightarrow \text { Ingestion } \\
\mathrm{SW-E3}=\mathrm{SW} \rightarrow \text { Irrigation } \rightarrow \text { Crops } \rightarrow \text { Ingestion } \\
\mathrm{SW-E4}=\mathrm{SW} \rightarrow \text { Irrigation } \rightarrow \text { Crops } \rightarrow \text { Animals } \rightarrow \text { Ingestion } \\
\mathrm{SW-ES}=\mathrm{SW} \rightarrow \text { Animals } \rightarrow \text { Ingestion }\end{array}$} \\
\hline
\end{tabular}


TABLE 4.19. LANL Population Distribution for Atmospheric Pathway

Inhalation Population $=159,122$

\begin{tabular}{|l|r|r|r|r|r|r|r|r|r|r||}
\hline \multirow{2}{*}{ Direction } & \multicolumn{10}{|c|}{ Distance from Site (km) } \\
\cline { 2 - 13 } & 1.6 & 3.2 & 4.9 & 6.5 & 8.1 & 16.1 & 32.3 & 48.4 & 64.5 & 80.1 \\
\hline \hline N & 0 & 0 & 0 & 0 & 0 & 0 & 0 & 642 & 0 & 936 \\
\hline NNE & 0 & 0 & 0 & 0 & 0 & 480 & 1832 & 3258 & 0 & 58 \\
\hline NE & 0 & 0 & 0 & 0 & 0 & 0 & 12271 & 1267 & 1744 & 2939 \\
\hline ENE & 0 & 63 & 0 & 0 & 0 & 1472 & 4359 & 899 & 2674 & 75 \\
\hline E & 0 & 0 & 0 & 0 & 0 & 0 & 1921 & 528 & 1 & 598 \\
\hline ESE & 0 & 0 & 0 & 0 & 0 & 0 & 548 & 4169 & 2163 & 0 \\
\hline SE & 0 & 0 & 0 & 2750 & 0 & 3423 & 9979 & 40933 & 196 & 6 \\
\hline SSE & 0 & 0 & 0 & 1902 & 1388 & 520 & 485 & 3670 & 814 & 289 \\
\hline S & 0 & 0 & 0 & 0 & 0 & 0 & 0 & 6 & 2974 & 2571 \\
\hline SSW & 0 & 0 & 0 & 0 & 0 & 0 & 839 & 2611 & 2385 & 17952 \\
\hline SW & 0 & 0 & 0 & 0 & 0 & 0 & 675 & 0 & 819 & 0 \\
\hline WSW & 0 & 0 & 0 & 0 & 0 & 0 & 0 & 316 & 141 & 5 \\
\hline W & 0 & 0 & 729 & 573 & 0 & 1275 & 0 & 1051 & 88 & 142 \\
\hline WNW & 0 & 0 & 1017 & 2138 & 2471 & 1152 & 0 & 0 & 0 & 1649 \\
\hline NW & 0 & 0 & 1684 & 0 & 0 & 0 & 0 & 768 & 0 & 459 \\
\hline NNW & 0 & 0 & 0 & 0 & 0 & 0 & 0 & 0 & 0 & 107 \\
\hline \hline
\end{tabular}


TABLE 4.20. Distribution of Agriculture Products Around the LANL

\begin{tabular}{||l|c|c|c|c|c|c||}
\hline Receptor Name & Direction & $\begin{array}{c}\text { Distance } \\
(\mathrm{km})\end{array}$ & $\begin{array}{c}\text { Leafy } \\
\text { Vegetables } \\
(\mathrm{kg} / \mathrm{yr})\end{array}$ & $\begin{array}{c}\text { Other } \\
\text { Vegetables } \\
(\mathrm{kg} / \mathrm{yr})\end{array}$ & $\begin{array}{c}\text { Meat } \\
(\mathrm{kg} / \mathrm{yr})\end{array}$ & $\begin{array}{c}\text { Milk } \\
(\mathrm{kg} / \mathrm{yr})\end{array}$ \\
\hline \hline Bernalillo & SSW & 80.0 & $7.60 \mathrm{E}+04$ & $3.78 \mathrm{E}+04$ & $3.72 \mathrm{E}+04$ & $3.89 \mathrm{E}+06$ \\
\hline Mora & ENE & 80.0 & $0.00 \mathrm{E}+00$ & $0.00 \mathrm{E}+00$ & $3.55 \mathrm{E}+04$ & $8.70 \mathrm{E}+04$ \\
\hline Rio Arribao & NNW & 80.0 & $5.26 \mathrm{E}+05$ & $3.24 \mathrm{E}+06$ & $1.36 \mathrm{E}+05$ & $3.72 \mathrm{E}+05$ \\
\hline San Miguel & ESE & 80.0 & $0.00 \mathrm{E}+00$ & $3.45 \mathrm{E}+04$ & $5.07 \mathrm{E}+05$ & $7.47 \mathrm{E}+05$ \\
\hline Sandoval & SW & 52.0 & $2.31 \mathrm{E}+05$ & $2.31 \mathrm{E}+04$ & $1.43 \mathrm{E}+05$ & $0.00 \mathrm{E}+00$ \\
\hline Santa Fe & SSE & 55.0 & $0.00 \mathrm{E}+00$ & $2.46 \mathrm{E}+06$ & $1.91 \mathrm{E}+05$ & $6.82 \mathrm{E}+05$ \\
\hline Taos & NE & 80.0 & $0.00 \mathrm{E}+00$ & $5.77 \mathrm{E}+04$ & $2.64 \mathrm{E}+04$ & $7.39 \mathrm{E}+04$ \\
\hline Los Alamos & NNW & 7.0 & $0.00 \mathrm{E}+00$ & $0.00 \mathrm{E}+00$ & $0.00 \mathrm{E}+00$ & $0.00 \mathrm{E}+00$ \\
\hline
\end{tabular}

Maywood is located in the humid continental warm summer climatic regime (see Table 4.21 for detailed climatic information). Precipitation averages 42 inches a year. Atmospheric dispersion data are obtained from measurements at the Newark International Airport in Newark, New Jersey.

The Maywood Site is located in the Newark Basin, which represents a southeastern branch of the Hudson River Valley Basin. The basin was the product of continental rifting and is characterized by numerous high-angle, northerly-trending normal faults, most of which also exhibit en echelon characteristics, with the tilted blocks dipping south. Since most of the sediments were deposited during or after the rifting event took place (TriassicJurassic periods), they display the red color common to rocks deposited during that time period. Some basaltic (igneous) rocks are also found within the basin sediments that, like the clastics, are the result of the continental rifting that took place in the early Mesozoic Era. These rocks are overlain by the unconsolidated sediments of the Pleistocene glaciation. These deposits are quite varied, due to the variety of processes and media that deposited them. Much of the 


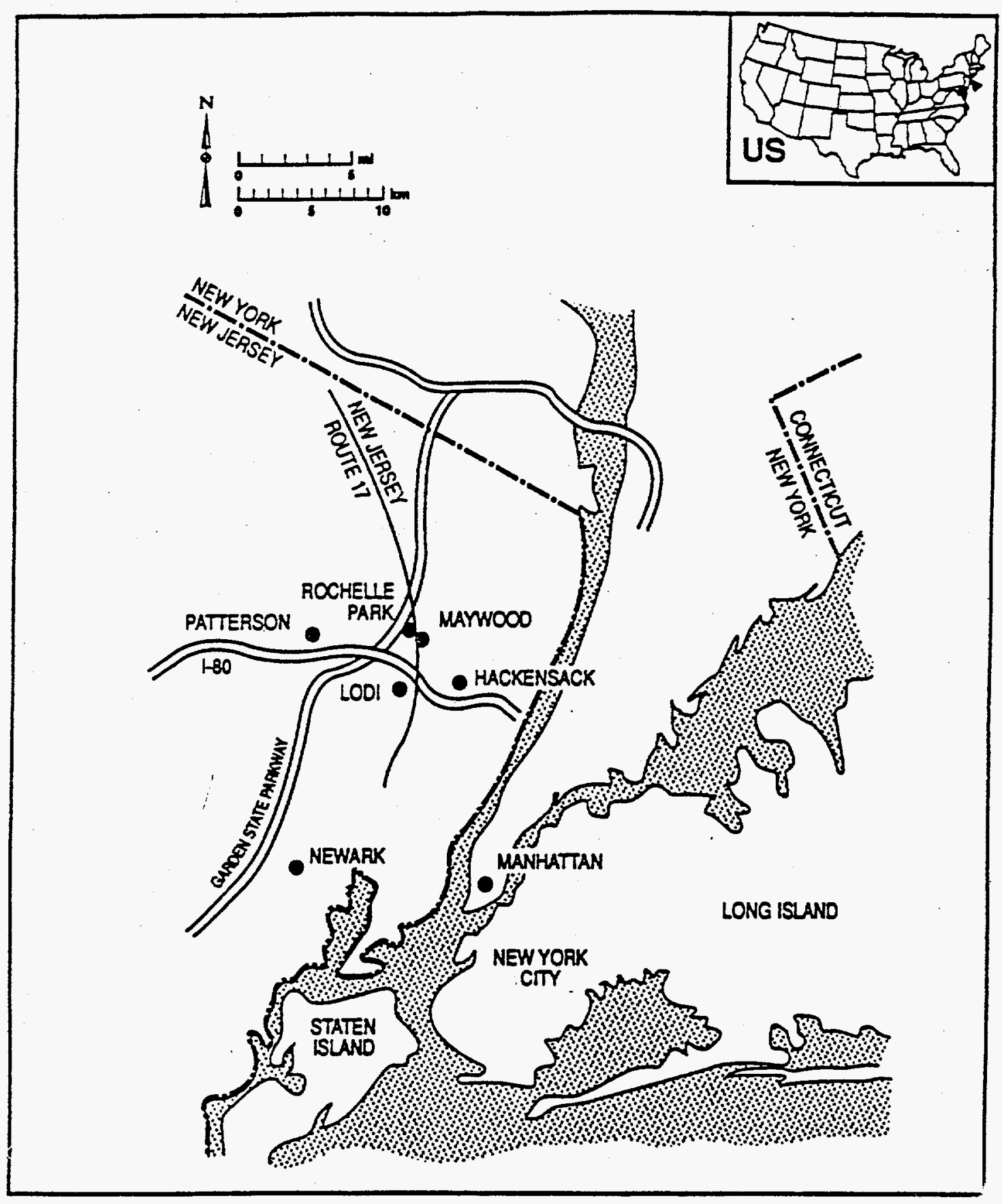

FIGURE 4.5. Location of the Maywood Site 


\section{TABLE 4.21. Maywood Average Local Climatology ${ }^{(a)}$}

Newark International Airport, Newark, New Jersey

Elevation:

Latitude:

Annual mean air temp:

Anemometer height:

Mean annual wind speed:

Fastest 1-min Wind speed:

Annual precipitation:

Precipitation days:

Thunderstorms freq:

Avg morning mixing ht:

Avg afternoon mixing ht:

Topsoil moisture capacity:

MEPAS parameters: (c)

Climatic region index:

Precipitation-Evaporation Index:

Soil Cons. Serv. Curve Number:
$2.13 \mathrm{~m}$

$40.70^{\circ} \mathrm{N}$

$54.2^{\circ} \mathrm{F}^{(\mathrm{b})}$

$6.1 \mathrm{~m}^{(\mathrm{b})}$

$10 \mathrm{mph}^{(\mathrm{b})}$

$82 \mathrm{mph}^{(\mathrm{b})}$

42.3 in. $^{(b)}$

$122 \mathrm{yr}^{-1(b)}$

$26 \mathrm{yr}^{-1(b)}$

$800 \mathrm{~m}^{(\mathrm{c})}$

$1300 \mathrm{~m}^{(0)}$

$5.8 \mathrm{~cm}^{(\mathrm{c})}$

$7^{(c)}$

$138^{(c)}$

$60^{(d)}$

\begin{tabular}{|c|c|c|c|c|c|c|c|}
\hline \multirow[b]{2}{*}{ Month } & \multicolumn{5}{|c|}{ MONTHLY AVERAGES } & \multicolumn{2}{|c|}{ DAILY RH } \\
\hline & $\begin{array}{c}\text { Temp. } \\
\left({ }^{\circ} \mathrm{F}\right)\end{array}$ & $\begin{array}{l}\text { Precip. } \\
\text { (inches) }\end{array}$ & Wind Speed (mph) & $\begin{array}{c}\text { Cloud Cover } \\
\text { (tenths) }\end{array}$ & $\begin{array}{l}\text { Precip. } \\
\text { Days (\#) }\end{array}$ & $\begin{array}{l}\operatorname{Max} \\
(\mathscr{\%})\end{array}$ & $\begin{array}{l}\text { Min } \\
(\mathscr{\%})\end{array}$ \\
\hline Jan & 31 & 3.13 & 11.3 & 6.4 & 11.1 & 74 & 58 \\
\hline Feb & 33 & 3.05 & 11.6 & 6.4 & 9.64 & 73 & 55 \\
\hline Mar & 41 & 4.15 & 12.1 & 6.3 & 11.4 & 69 & 51 \\
\hline Apr & 52 & 3.57 & 11.4 & 6.3 & 10.8 & 65 & 47 \\
\hline May & 62 & 3.59 & 10.1 & 6.5 & 12.7 & 71 & 51 \\
\hline Jun & 72 & 2.94 & 9.5 & 6.1 & 10.2 & 73 & 52 \\
\hline Jul & 77 & 3.85 & 8.9 & 6.2 & 9.99 & 72 & 51 \\
\hline Aug & 76 & 4.3 & 8.7 & 6 & 9.2 & 76 & 53 \\
\hline Sep & 68 & 3.66 & 9 & 5.7 & 8.3 & 78 & 55 \\
\hline Oct & 57 & 3.09 & 9.4 & 5.5 & 7.8 & 78 & 54 \\
\hline Nov & 47 & 3.59 & 10.2 & 6.4 & 10.3 & 77 & 57 \\
\hline Dec & 36 & 3.42 & 10.8 & 6.4 & 11.1 & 75 & 59 \\
\hline \multicolumn{8}{|c|}{$\begin{array}{l}\text { (a) Meteorological parameters are presented using the units with which they are routinely measured } \\
\text { (e.g., temperature: }{ }^{\circ} \mathrm{F} \text {, wind speed: mph). Data are from measurements made at the Newark } \\
\text { International Airport, } 13 \text { miles }(21 \mathrm{~km}) \text { southwest of Maywood, NJ. } \\
\text { (b) NCDC } 1986 . \\
\text { (c) Droppo et al. } 1989 . \\
\text { (d) DOE } 1992 .\end{array}$} \\
\hline
\end{tabular}


glacial sediment consists of fill or drift deposited by the glacier as it melted and retreated. Some of the finer clastics (clay) are the remains of the post-glacial Lake Hackensack, which stretched some 45 miles along the New Jersey coast from Tappan, New York, to a point south of Newark. This large glacial lake resulted in the deposition of up to $30.48 \mathrm{~m}$ of carved clays and stratified sand bodies.

These deposits have resulted in a fairly flat topography, with relief in the range of $9.14 \mathrm{~m}$. This glaciated portion of the Piedmont Plateau, of which the Maywood Site is a part, slopes slightly to the west and drains to the Passaic, Saddle, and Hackensack Rivers, which empty into the Hudson River and eventually the Atlantic Ocean.

Locally the site is underlain by the Passaic Formation, a thick sequence of sandstones and, less commonly, siltstones. The top of the Passaic is weathered and fractured, providing a conduit for groundwater flow. The overlying unconsolidated sediments are varied, but they can generally be separated into three different layers. The bottom layer, which rests on the Passaic Formation, is a group of fine-grained sands and silts that are well sorted and commonly stratified, representing relict deposits of glacial Lake Hackensack. The middle layer is a darker, clayey deposit, with localized soil horizons and sand channels, that likely represents the final stages of Lake Hackensack and its transition to a shallow, swampy environment. The upper unit consists of gravels, sands, and silts that are due to floodplain deposition in the Saddle River basin. These deposits have been reworked by natural processes and by human activity, including the ubiquitous fill that overlies these units.

The Maywood Site is characterized as one environmental setting containing four geohydrologic units (see Table 4.22). Although the unconsolidated sediments are rather heterogeneous, the data are sparse and really only allow for the 
TABLE 4.22. Geohydrologic Data for Maywood

\begin{tabular}{|c|c|c|c|c|c|c|c|c|c|c|}
\hline \multirow[b]{2}{*}{ Layer ${ }^{\left(a^{2}\right)}$} & \multirow[b]{2}{*}{ Textural Name } & \multirow[b]{2}{*}{ Thickness (m) } & \multirow[b]{2}{*}{$\begin{array}{c}\text { Bulk } \\
\text { Density } \\
\left(\mathrm{g} / \mathrm{cm}^{3}\right)\end{array}$} & \multirow[b]{2}{*}{$\begin{array}{l}\text { Total } \\
\text { Porosity } \\
(\%)\end{array}$} & \multirow[b]{2}{*}{$\begin{array}{c}\text { Field } \\
\text { Capacity } \\
(\%)\end{array}$} & \multirow{2}{*}{$\begin{array}{c}\text { Saturated } \\
\text { Hydraulic } \\
\text { Conductivity } \\
\text { (m/day) }\end{array}$} & \multicolumn{4}{|c|}{ SOIL CLASSIFICATION $^{(b)}$} \\
\hline & & & & & & & $\begin{array}{c}\text { Sand } \\
\%\end{array}$ & $\begin{array}{l}\text { Silt } \\
\%\end{array}$ & Clay \% & Organic \% \\
\hline PSZ-1 & Sandy clay loam ${ }^{(b)}$ & 0.91 & 1.6 & 40 & 22 & 0.18 & 60 & 14 & 26 & $\mathbf{0}$ \\
\hline PSZ-2 & Sandy loam & 0.91 & 1.48 & 20 & 17.5 & 25 & 65 & 25 & 10 & $\mathbf{0}$ \\
\hline SZ-1 & $\begin{array}{l}\text { Sandy loam } \\
\qquad \begin{array}{l}\text { Groundwater velocity }=2.5 \mathrm{~m} / \mathrm{day} \\
\text { Effective porosity }=10 \%\end{array}\end{array}$ & 2.1 & 1.48 & 20 & - & -- & 65 & 25 & 10 & $\mathbf{0}$ \\
\hline sZ-2 & $\begin{array}{l}\text { Sandy loam } \\
\quad \text { Groundwater velocity }=3.8 \mathrm{~m} / \mathrm{day} \\
\text { Effective porosity }=1 \%\end{array}$ & 2.4 & 1.42 & 47 & -- & -- & 45 & 40 & 15 & $\mathbf{0}$ \\
\hline sw & $\begin{array}{l}\text { Width of river }=30.5 \mathrm{~m} \\
\text { Depth of river }=1.2 \mathrm{~m} \\
\text { Annual average velocity of river }= \\
7.6 \mathrm{~cm} / \mathrm{s} \\
\text { Discharge rate }=2.8 \mathrm{~m}^{3} / \mathrm{s}\end{array}$ & & & & & & & & & \\
\hline
\end{tabular}


meaningful description of one general layer. Any attempt to produce a characterization with a higher resolution (i.e., more layers) would result in a complex maze of overlapping, discontinuous layers and would mislead the modeler into thinking the site had undergone more analysis than it really had or than is even possible.

Thicknesses were determined by extrapolating average thicknesses of beds (and the depth of the water table) from the cross-sections included in the Remedial Investigation (RI) Report.

It was determined that the overlying sediments had an approximate average thickness of $3.96 \mathrm{~m}$, and the water table had an approximate average depth of $1.83 \mathrm{~m}$. A topsoil/fill layer was also included, to account for the extensive human alteration of the land surface. Data for this topsoil layer were obtained from the RI Report's description of a CREAMS model run that used parameters similar to those used in MEPAS.

Soil class was chosen by relating a parameter value present in the RI to a similar value in a table of representative values (Table 2-1) found on page 2.5 in Volume II of the MEPAS manual (Droppo et al. 1989). The parameter found in the RI used in the determination varied from layer to layer; sometimes a field capacity and a porosity were given, as in the case of the topsoil/fill layer, or (more often) a saturated hydraulic conductivity test value was used. The soil class was then used to determine default values for parameters for which no value could be found.

Dispersivities were not found anywhere in the RI; they were determined by using default values per MEPAS procedures. For unsaturated zones, the dispersivity default value is 0.01 of the thickness of the geologic unit (THICK). For saturated zones, the longitudinal dispersivity is 0.1 of the distance from the 
middle of the site to the nearest receptor. Since the environmental settings task group was not privy to receptor information, it was assumed that the receptor is the nearest point of the Saddle River to the Maywood Site, which is the intersection of the Saddle River with the eastbound lanes of Interstate 80. Transverse and vertical dispersivity were then calculated using this longitudinal dispersivity value.

In general, a substantial amount of conservatism is built into this characterization. Many default values were used and, by design, lend a certain amount of conservatism to the model. Additionally, the highest flow velocities and conductivities were often chosen, causing the contaminant transport scenarios to appear much more pessimistic than is likely the case. For instance, the overburden was characterized as sandy loam, when the average measured conductivity falls in the sandy clay loam category. Numerous small clay layers exist in the overburden, but, as was mentioned before, they are too thin and discontinuous to characterize in this project. Therefore, it was determined that the most conservative conductivity would be used to choose the soil class, imparting a prudent conservatism to the characterization.

Exposure/receptor data, population data, and data on the distribution of agricultural products were not immediately available for this site. These data were compiled by Oak Ridge National Laboratory and are provided in Volume IV.

\subsection{Sandia National Laboratory - AlbuQuerQue}

The Sandia National Laboratory Albuquerque (SNLA) comprises $63 \mathrm{~km}^{2}$ (24 $\mathrm{mi}^{2}$ ) located in various technical areas and test sites on and next to Kirtland Air Force Base (KAFB) in the southeastern corner of Albuquerque, New Mexico (Figure 4.6). Most facilities are located on two mesas separated by the Tijeras Arroyo. 


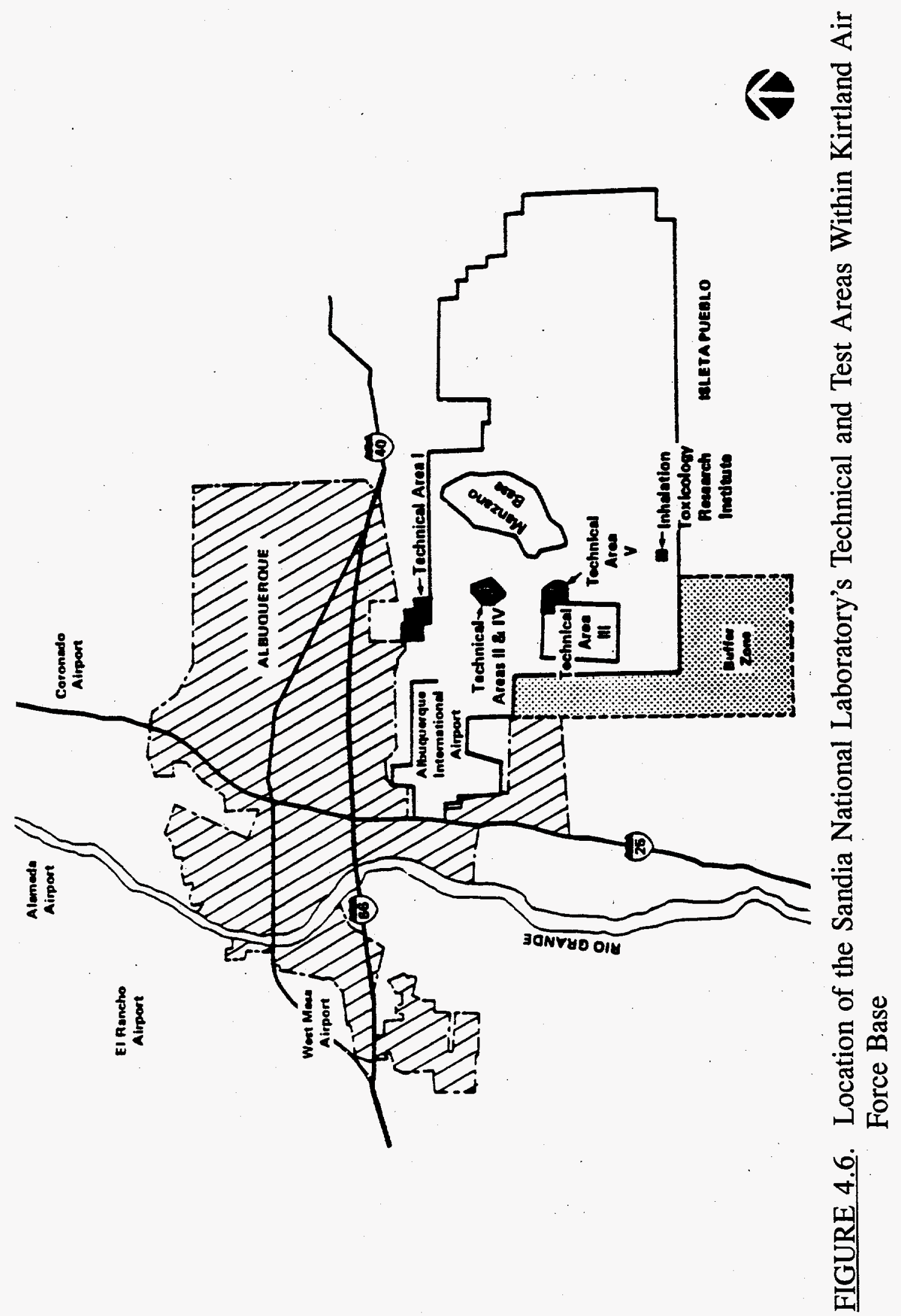


The climate of the region can be categorized as semiarid, a climate characteristic of much of the intermountain western states (see Table 4.23 for detailed climatic information). Meteorological data are obtained from the Albuquerque Airport. Precipitation averages $20 \mathrm{~cm}(8 \mathrm{in}$.) per year. Site winds are characterized using joint frequency distributions.

The Rio Grande River is located to the west of the SNLA site. The principal aquifer is termed "valley fill" and comprises unconsolidated and semiconsolidated sands, gravels, silts, and clays, as well as more recent alluvial deposits. It varies in thickness from a few feet adjacent to mountain ranges to a depth of over $6,400 \mathrm{~m}(21,000 \mathrm{ft})$. Detailed geohydrologic data are presented in Table 4.24 and exposure/receptor data are presented in Table 4.25.

Within a few kilometers of the SNLA site, the local population numbers several tens of thousands of people. Within $80 \mathrm{~km}(50 \mathrm{mi})$ of the facility, the population is approximately half a million people. Detailed population data are presented in Table 4.26, and data on the distribution of agricultural products are presented in Table 4.27 . 


\section{TABLE 4.23. Sandia National Laboratory Average Local Climatology ${ }^{(\mathrm{a}, \mathrm{b})}$}

Albuquerque National Weather Station, Albuquerque, New Mexico

$\begin{array}{ll}\text { Elevation: } & 1,619 \mathrm{~m} \\ \text { Latitude: } & 35.05^{\circ} \mathrm{N} \\ \text { Annual Mean Air Temp: } & 55.8^{\circ} \mathrm{F} \\ \text { Anemometer Height: } & 7.0 \mathrm{~m} \\ \text { Mean Annual Wind Speed: } & 9 \mathrm{mph} \\ \text { Fastest 1-Min Wind Speed: } & 90 \mathrm{mph} \\ \text { Annual Precipitation: } & 8.3 \mathrm{in} . \\ \text { Precipitation Days: } & 60 \mathrm{yr}^{-1} \\ \text { Thunderstorms Freq: } & 42 \mathrm{yr}^{-1} \\ \text { Avg Morning Mixing Ht: } & 450 \mathrm{~m} \\ \text { Avg Afternoon Mixing Ht: } & 2600 \mathrm{~m} \\ \text { Topsoil Moisture Capacity: } & 1.8 \mathrm{~cm}\end{array}$

\begin{tabular}{|c|c|c|c|c|c|c|c|}
\hline \multirow[b]{2}{*}{ Month } & \multicolumn{5}{|c|}{ Monthly Averages } & \multicolumn{2}{|c|}{ Daily RH } \\
\hline & $\begin{array}{c}\text { Temp. } \\
\left({ }^{\circ} \mathbf{F}\right)\end{array}$ & $\begin{array}{l}\text { Precip. } \\
\text { (inches) }\end{array}$ & Wind Speed (mph) & $\begin{array}{l}\text { Cloud Cover } \\
\text { (tenths) }\end{array}$ & $\begin{array}{l}\text { Precip. } \\
\text { Days (\#) }\end{array}$ & $\begin{array}{c}\text { Max } \\
(\%)\end{array}$ & $\underset{(\%)}{\operatorname{Min}}$ \\
\hline Jan & 35 & 0.41 & 8.0 & 4.8 & 3.9 & 71 & 40 \\
\hline Feb & 39 & 0.40 & 8.8 & 4.9 & 4.1 & 65 & 32 \\
\hline Mar & 46 & 0.52 & 10.1 & 5.1 & 4.6 & 56 & 24 \\
\hline Apr & 55 & 0.40 & 11.0 & 4.6 & 3.3 & 49 & 18 \\
\hline May & 64 & 0.46 & 10.5 & 4.2 & 4.3 & 48 & 18 \\
\hline Jun & 75 & 0.51 & 10.0 & 3.3 & 3.8 & 46 & 17 \\
\hline Jul & 79 & 1.30 & 9.1 & 4.5 & 8.9 & 60 & 27 \\
\hline Aug & 76 & 1.51 & 8.2 & 4.3 & 9.2 & 66 & 30 \\
\hline Sep & 69 & 0.85 & 8.6 & 3.6 & 5.7 & 62 & 31 \\
\hline Oct & 57 & 0.86 & 8.3 & 3.5 & 4.9 & 62 & 30 \\
\hline Nov & 44 & 0.38 & 7.9 & 4.0 & 3.5 & 66 & 36 \\
\hline Dec & 36 & 0.52 & 7.7 & 4.6 & 4.1 & 71 & 43 \\
\hline
\end{tabular}

(a) Meteorological parameters are presented using the units with which they are routinely measured (e.g., temperature in ${ }^{\circ} \mathrm{F}$, wind speed in $\mathrm{mph}$ ). Temperature and precipitation averages are based on a 30-year climatologically representative period (1951 - 1980). Other averages are based on 26 to 47 years of data.

(b) MEPAS Parameters: Climatic Region Index: 2

Precipitation-Evaporation Index: 18

Soil Cons. Serv. Curve Number: 41 


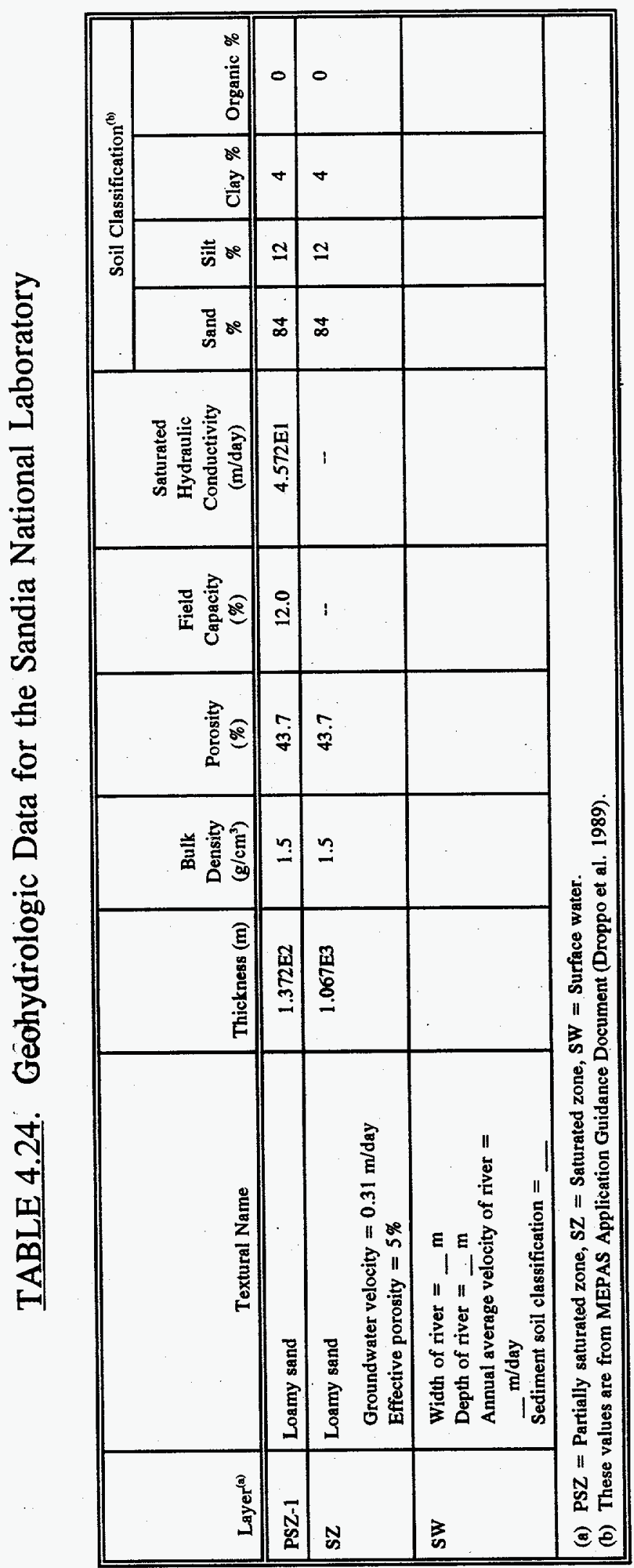


TABLE 4.25. Exposure Data for the Sandia National Laboratory

\begin{tabular}{|c|c|c|c|c|c|c|c|c|c|c|c|}
\hline $\begin{array}{l}\text { Receptor } \\
\text { Name }\end{array}$ & $\begin{array}{c}\text { Drinking Water } \\
\text { Population }\end{array}$ & $\begin{array}{c}\text { Distance to } \\
\text { Receptor }(\mathrm{m})\end{array}$ & $\begin{array}{c}\text { Leafy } \\
\text { Vegetable } \\
\text { (kg/yr) }\end{array}$ & $\begin{array}{c}\text { Other } \\
\text { Vegetables } \\
\text { (kg/yr) }\end{array}$ & $\begin{array}{c}\text { Milk } \\
(\mathrm{kg} / \mathrm{yr})\end{array}$ & $\begin{array}{c}\text { Meat } \\
(\mathrm{kg} / \mathrm{yr})\end{array}$ & $\begin{array}{l}\text { Finfish } \\
(\mathrm{kg} / \mathrm{yr})\end{array}$ & $\begin{array}{l}\text { Shellfish } \\
(\mathrm{kg} / \mathrm{yr})\end{array}$ & $\begin{array}{l}\text { Recreation } \\
\text { Population }\end{array}$ & $\begin{array}{c}\text { Discharge } \\
\text { Rate }\left(\mathrm{m}^{3} / \mathrm{day}\right)\end{array}$ & $\begin{array}{l}\text { Exposure } \\
\text { Routes for } \\
\text { Receptor }\end{array}$ \\
\hline $\begin{array}{l}\text { Albuquerque } \\
\# 11\end{array}$ & 43,922 & 5,102 & $0.00 E+00$ & $0.00 \mathrm{E}+00$ & $0.00 \mathrm{E}+00$ & $0.00 \mathrm{E}+00$ & -- & -- & -- & -- & $\mathrm{GW}(\mathrm{E} 1, \mathrm{E} 2)$ \\
\hline $\begin{array}{l}\text { Albuquerque } \\
\$ 2\end{array}$ & 35,995 & 8,321 & $0.00 E+00$ & $0.00 \mathrm{E}+00$ & $0.00 \mathrm{E}+00$ & $0.00 \mathrm{E}+00$ & -- & -- & -. & -- & GW(E1,E2) \\
\hline $\begin{array}{l}\text { OS Wells } \\
1, \mathbf{3}, \mathbf{4}, 7\end{array}$ & 912 & 3,219 & $0.00 E+00$ & $0.00 \mathrm{E}+00$ & $0.00 \mathrm{E}+\infty 0$ & $0.00 \mathrm{E}+\infty 0$ & -- & -- & - & -- & GW(E1) \\
\hline $\begin{array}{l}\text { OS Wells } \\
2,12,13,14\end{array}$ & 1,260 & 6,035 & $0.00 \mathrm{E}+\infty$ & $0.00 \mathrm{E}+00$ & $0.00 \mathrm{E}+00$ & $0.00 E+00$ & $\therefore$ & -- & - & -- & GW(E1) \\
\hline \multicolumn{12}{|c|}{ Key for Exposure Routes } \\
\hline $\begin{array}{l}\text { GW-E1 }=G 1 \\
G W-E 2=G 1\end{array}$ & $\begin{array}{l}\text { Ingestion } \\
\text { Bathing/show }\end{array}$ & & & & & & & & & & \\
\hline
\end{tabular}


TABLE 4.26. Sandia National Laboratory Population Distribution for Atmospheric Pathway

Inhalation Population $=496,191$

\begin{tabular}{||r|r|r|r|r|r|r|r|r|r|r||}
\hline \multirow{2}{*}{ Direction } & \multicolumn{7}{|c|}{ Distance from Site (km) } \\
\cline { 2 - 12 } & 1.6 & 3.2 & 4.9 & 6.5 & 8.1 & 16.1 & 32.3 & 48.4 & 64.5 & 80.1 \\
\hline \hline N & 0 & 0 & 0 & 1128 & 4087 & 72826 & 10477 & 4851 & 896 & 1013 \\
\hline NNE & 0 & 0 & 0 & 1493 & 1030 & 8724 & 3309 & 3448 & 2210 & 501 \\
\hline NE & 0 & 0 & 0 & 0 & 0 & 1500 & 2933 & 0 & 814 & 3670 \\
\hline ENE & 0 & 0 & 0 & 0 & 0 & 151 & 327 & 829 & 0 & 295 \\
\hline E & 0 & 0 & 0 & 0 & 0 & 0 & 0 & 1276 & 0 & 0 \\
\hline ESE & 0 & 0 & 0 & 0 & 0 & 697 & 0 & 1288 & 1695 & 82 \\
\hline SE & 0 & 0 & 0 & 0 & 0 & 0 & 0 & 802 & 166 & 222 \\
\hline SSE & 0 & 0 & 0 & 0 & 49 & 0 & 0 & 0 & 1526 & 0 \\
\hline S & 0 & 0 & 0 & 0 & 0 & 0 & 1503 & 290 & 0 & 0 \\
\hline SSW & 0 & 0 & 0 & 0 & 0 & 0 & 1273 & 8409 & 1385 & 1624 \\
\hline SW & 0 & 0 & 0 & 0 & 0 & 0 & 11083 & 6727 & 8 & 0 \\
\hline WSW & 0 & 0 & 0 & 0 & 0 & 51 & 3418 & 43 & 15 & 40 \\
\hline W & 0 & 0 & 0 & 0 & 0 & 5255 & 10967 & 0 & 168 & 1140 \\
\hline WNW & 0 & 0 & 0 & 0 & 0 & 14231 & 40465 & 0 & 848 & 172 \\
\hline NW & 0 & 0 & 0 & 0 & 0 & 61887 & 52485 & 0 & 0 & 69 \\
\hline NNW & 0 & 0 & 5510 & 0 & 0 & 75622 & 53124 & 1826 & 519 & 1719 \\
\hline \hline
\end{tabular}


TABLE 4.27. Distribution of Agriculture Products Around the Sandia National Laboratory

\begin{tabular}{|l|c|c|c|c|c|c|}
\hline \multicolumn{1}{|c|}{ Receptor Name } & Direction & $\begin{array}{c}\text { Distance } \\
(\mathrm{km})\end{array}$ & $\begin{array}{c}\text { Leafy } \\
\text { Vegetables } \\
(\mathrm{kg} / \mathrm{yr})\end{array}$ & $\begin{array}{c}\text { Other } \\
\text { Vegetables } \\
(\mathrm{kg} / \mathrm{yr})\end{array}$ & $\begin{array}{c}\text { Meat } \\
(\mathrm{kg} / \mathrm{yr})\end{array}$ & $\begin{array}{c}\text { Milk } \\
(\mathrm{kg} / \mathrm{yr})\end{array}$ \\
\hline Bernalillo City & $\mathrm{W}$ & 20.0 & $0.00 \mathrm{E}+00$ & $1.29 \mathrm{E}+06$ & $7.56 \mathrm{E}+05$ & $3.42 \mathrm{E}+06$ \\
\hline Cibola City & $\mathrm{W}$ & 70.0 & $0.00 \mathrm{E}+00$ & $4.30 \mathrm{E}+04$ & $9.61 \mathrm{E}+04$ & $5.47 \mathrm{E}+04$ \\
\hline Sandoval City & $\mathrm{N}$ & 60.0 & $0.00 \mathrm{E}+00$ & $7.67 \mathrm{E}+06$ & $2.62 \mathrm{E}+05$ & $5.82 \mathrm{E}+06$ \\
\hline Santa Fe City & $\mathrm{NE}$ & 40.0 & $0.00 \mathrm{E}+00$ & $8.84 \mathrm{E}+05$ & $3.83 \mathrm{E}+05$ & $4.59 \mathrm{E}+05$ \\
\hline Socorro City & $\mathrm{S}$ & 70.0 & $0.00 \mathrm{E}+00$ & $2.75 \mathrm{E}+05$ & $1.85 \mathrm{E}+05$ & $2.40 \mathrm{E}+06$ \\
\hline Torrance City & $\mathrm{SE}$ & 50.0 & $0.00 \mathrm{E}+00$ & $6.72 \mathrm{E}+06$ & $3.41 \mathrm{E}+05$ & $1.71 \mathrm{E}+05$ \\
\hline Valencia City & $\mathrm{SSW}$ & 40.0 & $0.00 \mathrm{E}+00$ & $4.17 \mathrm{E}+05$ & $4.38 \mathrm{E}+05$ & $3.20 \mathrm{E}+07$ \\
\hline
\end{tabular}




\section{CHAPTER 5: BIBLIOGRAPHY}

Autrey, J. W., O. A. Costanzo, W. H. Griest, L. L. Kaiser, J. M. Keller, C. E. Nix, and B. A. Tomkins. 1990. Sampling and Analysis of the Inactive Waste Storage Tank Contents at ORNL. ORNL/ER-13, Oak Ridge National Laboratory, Oak Ridge, Tennessee.

$\mathrm{CH}_{2} \mathrm{M}$ Hill. 1987. Contamination Assessment Report for the Pinellas Plant: Northeast Groundwater Investigation. Prepared for the U.S. Department of Energy and General Electric Company by $\mathrm{CH}_{2} \mathrm{M}$ Hill, Tampa, Florida.

Droppo, J. G. Jr., D. L. Strenge, J. W. Buck, B. L. Hoopes, R. D. Brockham, M. B. Walter, and G. Whelan. 1989. Multimedia Environmental Pollutant Assessment System. PNL-7216, Pacific Northwest Laboratory, Richland, Washington.

Egge, R. G. 1992. Annual Surveillance and Maintenance Report for the Retired Hanford Site Facilities: Fiscal Year 1992. WHC-EP-0535-1, Westinghouse Hanford Company, Richland, Washington.

Evans, J. C., R. W. Bryce, and D. J. Bates. 1992. Hanford Site Groundwater Monitoring for 1990. PNL-8073, Pacific Northwest Laboratory, Richland, Washington.

Hanford Environmental Impact Statement Database (HEIS). 1993. Data on Monitoring Wells. Pacific Northwest Laboratory, Richland, Washington.

Horton, J. R. 1984. Preliminary Decommissioning Study Reports, Volume 4, Gunite Storage Tanks. ORNL/M-1921, Oak Ridge National Laboratory, Oak Ridge, Tennessee.

Inhalation Toxicology Research Institute (ITRI). 1992. Assessment Plan, Hot Ponds. ADS \#ALIT-1015, ITRI, Albuquerque, New Mexico. 
Keele, B. D., C. R. Neff, and V. B. Subrahmanyam. 1990. Radiological Characterization of 233-S Facility. WHC-SD-CP-TI-163, Westinghouse Hanford Company, Richland, Washington.

Los Alamos National Laboratory (LANL). 1992. RFI Work Plan for OU 1148, Material Disposal Area L, Chapter 5 and Appendix A. LA-UR-92-855, LANL, Albuquerque, New Mexico.

Miller, R. L., and J. R. Steffes. 1986. Radionuclide Inventory and Source Terms for the Surplus Production Reactors at Hanford. UNI-3714, United Nuclear Industries, Richland, Washington.

National Climate Data Center (NCDC). 1986. Local Climatological Data - Annual Summary with Comparative Data - Newark (Newark International Airport), New Jersey. NCDC, Ashville, North Carolina.

Newcomer, D. R., K. D. Pohlod, and J. P. McDonald. 1991. Water-Table Elevations on the Hanford Site, 1990. PNL-7693, Pacific Northwest Laboratory, Richland, Washington.

Pacific Northwest Laboratory (PNL). 1975. Resource Book - Decommissioning of Contaminated Facilities at Hanford. PNL-MA-588, Pacific Northwest Laboratory, Richland, Washington.

Speer, D. R. 1992. REDOX and U-Plant Decommissioning: Long-Range Plan. WHC-SDDD-PD-003, Westinghouse Hanford Company, Richland, Washington.

U.S. Department of Energy (DOE). 1988a. Environmental Survey Preliminary Report. DOE/EH/OEV-18-P, Sandia National Laboratories, Albuquerque, New Mexico.

U.S. Department of Energy (DOE). 1988b. Environmental Survey Preliminary Report. DOE/EH/OEV-31-P, Oak Ridge National Laboratory, Oak Ridge, Tennessee. 
U.S. Department of Energy (DOE). March 1989. Draft Environmental Impact Statement, Decommissioning of Eight Surplus Production Reactors at the Hanford Site, Richland, Washington. DOE/EIS-0119D, DOE, Washington, D.C.

U.S. Department of Energy (DOE). 1992a. Integrated Data Base for 1992: U.S. Spent Fuel and Radioactive Waste Inventories, Projections, and Characteristics. DOE/RW-006 Rev. 8, DOE, Washington, D.C.

U.S. Department of Energy (DOE). 1992b. Remedial Investigation Report for the Maywood Site, New Jersey. DOE/OR/21949-337, Vols. 1 and 2, Bechtel National, Inc., Oak Ridge, Tennessee.

U.S. Department Of Energy (DOE). 1992c. Interim Record of Decision for the Oak Ridge National Laboratory Waste Area Grouping 13 Cesium Plots. DOE/OR-1059\&DO, Oak Ridge National Laboratory, Oak Ridge, Tennessee. 


\section{APPENDIX A}

\section{DESCRIPTION OF $1^{\text {TH }}$ EXAMPLE SITE}




\section{APPENDIX A}

\section{DESCRIPTION OF $11^{\text {TH }}$ EXAMPLE SITE}

\section{A.1 ACtinide-Contaminated Soll Site}

Overview of Site

A representative actinide-contaminated soil site is similar to the Ashland 1 property located at the Tonawanda Site, ${ }^{(a)}$ whose remediation is being addressed under the Formerly Utilized Sites Remedial Action Program (FUSRAP). Between 1944 and 1946, under the auspices of the Manhattan Engineering District (MED), this site served as a disposal site for approximately 7,250 metric tons $(t)$ of ore refinery residues. These residues were generated from the first of a three-phase process used to separate uranium from uranium ores and tailings. The principal solid waste resulting from Phase 1 was a solid, gelatinous cake consisting of impurities remaining after filtration of uranium carbonate solutions. Phase 1 also produced insoluble precipitates of the dissolved constituents, which were combined with the tailings. The precipitated species included large quantities of silicon dioxide, iron hydroxide, calcium hydroxide, calcium carbonate, aluminum hydroxide, lead sulfate, lead vanadate, barium sulfate, barium carbonate, magnesium hydroxide, magnesium carbonate, and iron complexes of vanadium and phosphorus.

(a) Remedial Investigation Report for the Tonawanda Site, New York, Volume I. December 1992. DOE/OR/21949-300, Oak Ridge, Tennessee. 


\section{Physical Description}

The location of this contaminated property, which is currently being used for disassembly of oil refinery equipment, is shown in Figure A.1. It is a 4.4-hectare tract of land approximately $358 \mathrm{~m}$ long by $122 \mathrm{~m}$ wide. The ore refinery residues, containing approximately $0.54 \%$ uranium oxide, were spread over roughly two-thirds of the property to estimated depths of 0.3 to $1.5 \mathrm{~m}$. The total volume of contaminated soil at this site is estimated to be approximately $64,200 \mathrm{~m}^{3}$. Table A.1 summarizes the physical characteristics of this contaminated soil region.

In the middle of the property, a 1.2-hectare area is enclosed by a large berm constructed in 1974 to capture spills from two large petroleum product storage tanks. Construction of the tanks, which were removed in 1989, involved excavation and removal of approximately $4,600 \mathrm{~m}^{3}$ of contaminated fill material. Some of the excavated contaminated fill material was then used to build the earthen berms surrounding the storage tanks. The area inside the berms, which are $2.1 \mathrm{~m}$ high at the highest point, and the inner area of the northern part of the property, is mostly bare soil. Native grasses, weeds, and shrubs make up the site vegetation.

\section{Description of Contamination}

The results of remedial investigation activities at this site produced the approximate areal extent and depths of the radiologically contaminated areas shown in Figure A.2. The estimated depths of contamination are conservative, because when only a lens of contamination is found (e.g., between 1.5 and $2.1 \mathrm{~m}$ ), all soil above the contamination (e.g., between 0 and $1.5 \mathrm{~m}$ ) is considered to be contaminated. 


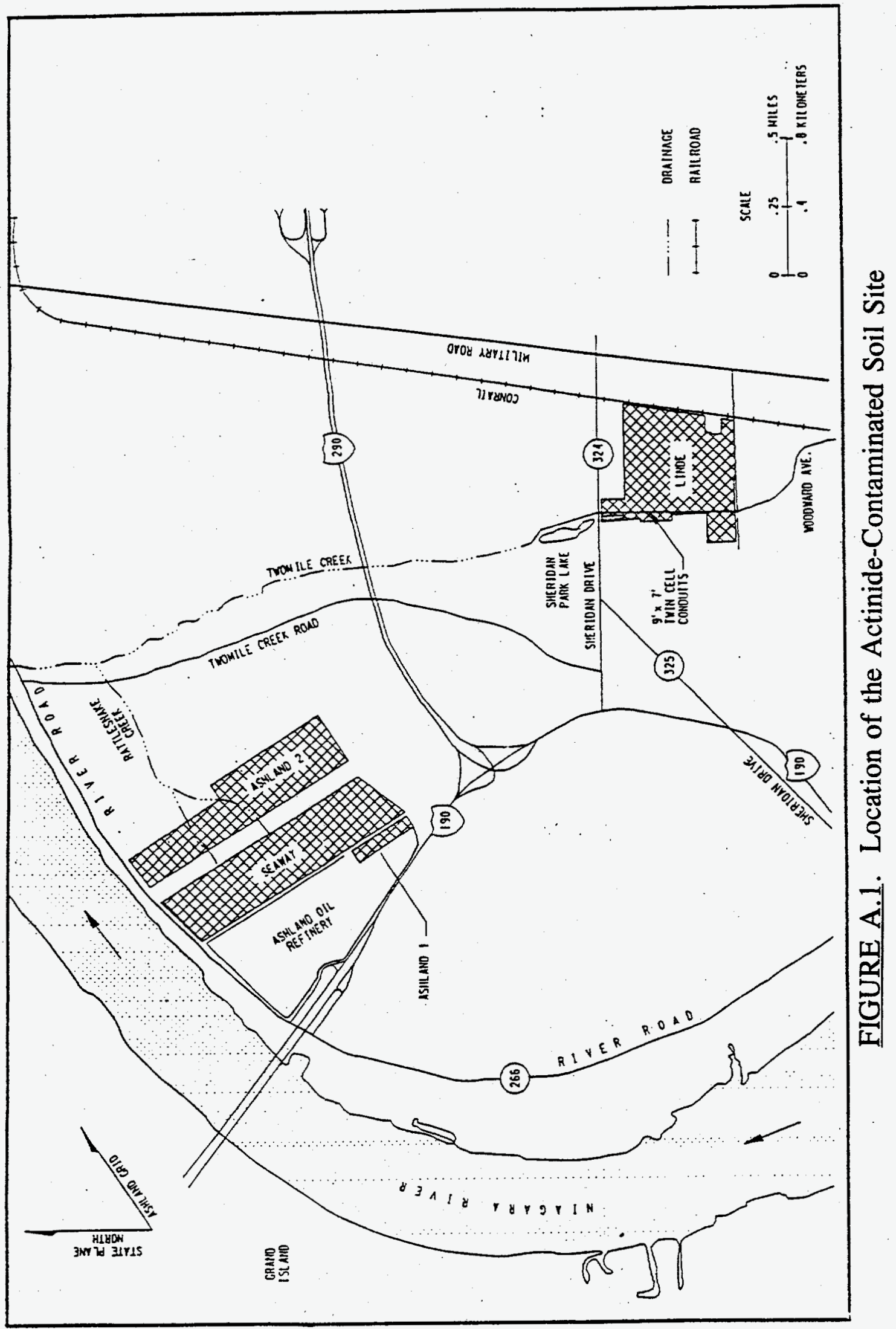


TABLE A.1. Physical Characteristics of Contaminated Soil

\begin{tabular}{||l|c|c||}
\hline \multicolumn{1}{|c|}{ Dimension } & Values & Units \\
\hline Length & 240 & $\mathrm{~m}$ \\
\hline Width & 122 & $\mathrm{~m}$ \\
\hline Depth & 2.1 & $\mathrm{~m}$ \\
\hline Overburden Depth & 0 & $\mathrm{~m}$ \\
\hline Surface Area & 3.1 & $\mathrm{ha}$ \\
\hline Volume of Contaminated Soil & 64,200 & $\mathrm{~m}^{3}$ \\
\hline Years of Disposal & $1944-1946$ & \\
\hline Elevation of Site Surface & 183 & $\begin{array}{c}\mathrm{m} \\
\mathrm{ms} 1^{(a)}\end{array}$ \\
\hline (a) mean seal level & & \\
\hline
\end{tabular}

The greatest depth of suspected contamination is found in just one borehole at $4.5 \mathrm{~m}$. It is thought that contamination was introduced to that depth when a PVC pipe was installed in the borehole to allow gamma-logging; no other boreholes show radioactive contamination below $3.3 \mathrm{~m}$. The varying depths of contamination at this site are a result of excavation activities that occurred after disposal of the ore refinery residues ceased.

The primary radioactive contaminants in the soils at this site are thorium-230 (Th-230), uranium-238 (U-238), and radium-226 (Ra-226). No thorium-232 (Th-232) concentrations exceed guidelines. Thorium-230 is the primary contaminant in the areas outside the property boundaries (i.e., west and north of the property). 


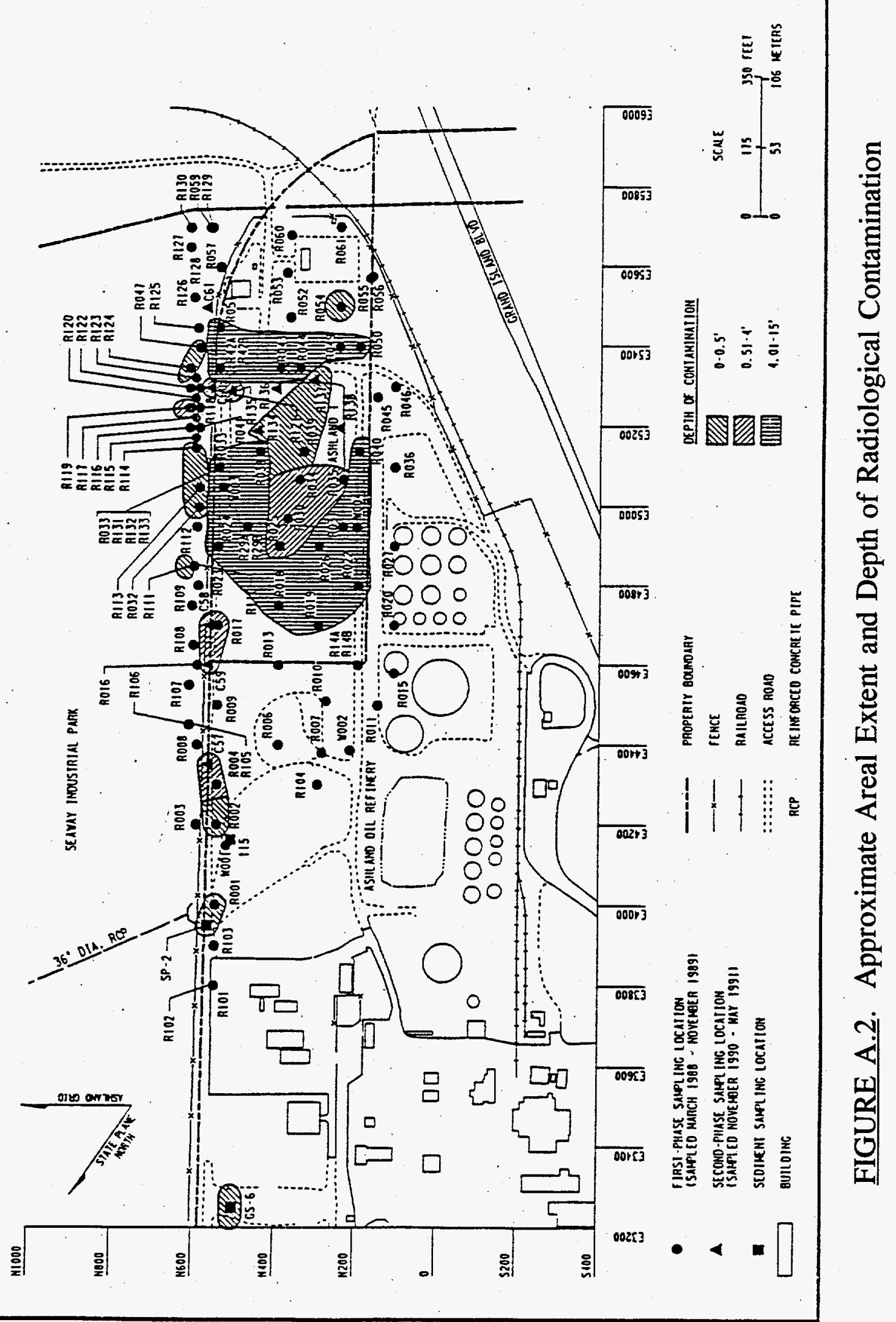


Concentrations of Th-230 that exceed guidelines are found predominantly between the surface and $0.6 \mathrm{~m}$ deep throughout the contaminated areas, both on and off of the property boundaries. The higher Th-230 concentrations are primarily in the southern portion and along the northern property line.

Uranium-238 contamination is found in conjunction with either Th-230 or Ra-226 or both and in the southern and western portions of the property. Because of mixing, there is no apparent pattern in the depth of U-238 contamination, and only one offsite borehole shows U-238 concentrations exceeding guidelines.

Radium-226 contamination, although found less frequently than either Th-230 or U-238 contamination, is found in the southern and western portions of the property. As with the other radionuclides, there is no apparent pattern in the depth of Ra-226 contamination. No offsite boreholes show Ra-226 concentrations that exceed guidelines.

Other constituents of interest at this site that may be due to the disposal of MED-related ore refinery residues include various metals such as aluminum, calcium, copper, iron, lead, magnesium, manganese, phosphorus, and vanadium. Because this site has been and is currently being used for nonMED-related activities, the site may also contain elevated levels of metals from slag used as a fill material (e.g., calcium, magnesium, manganese, and iron) and oil refinery wastes (e.g., arsenic, chromium, and lead), and organics from oil refinery wastes and accidental releases from the former petroleum product storage tanks.

Table A.2 summarizes the results of sampling activities at this site by providing the average and maximum concentration values detected for each constituent. 


\section{TABLE A.2. Constituent Concentrations and Inventories Present in the Contaminated Soil}

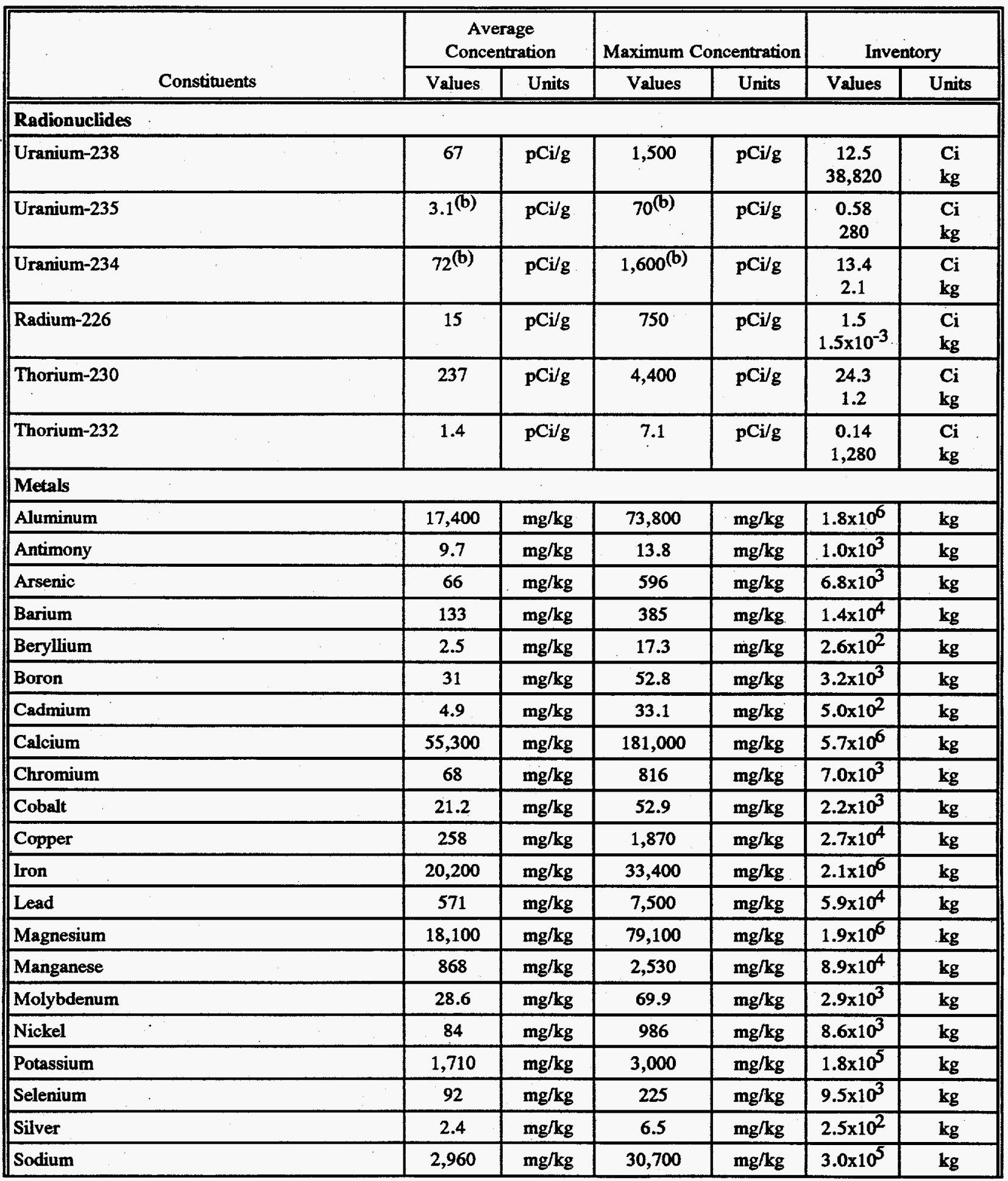


TABLE A.2. (contd)

\begin{tabular}{|c|c|c|c|c|c|c|}
\hline \multirow[b]{2}{*}{ Constituents } & \multicolumn{2}{|c|}{$\begin{array}{c}\text { Average } \\
\text { Concentration }\end{array}$} & \multicolumn{2}{|c|}{ Maximum Concentration } & \multicolumn{2}{|c|}{ Inventory } \\
\hline & Values & Units & Values & Units & Values & Units \\
\hline Thallium & 46.4 & $\mathrm{mg} / \mathrm{kg}$ & 65.4 & $\mathrm{mg} / \mathrm{kg}$ & $4.8 \times 10^{8}$ & kg \\
\hline Uranium & $\begin{array}{l}210^{(b)} \\
142^{(b)}\end{array}$ & $\begin{array}{l}\mathrm{mg} / \mathrm{kg} \\
\mathrm{pCi} / \mathrm{kg}\end{array}$ & $\begin{array}{l}4,680^{(b)} \\
3,170^{(b)}\end{array}$ & $\begin{array}{l}\mathrm{mg} / \mathrm{kg} \\
\mathrm{pCi} / \mathrm{g}\end{array}$ & $\begin{array}{l}3.9 \times 10^{4} \\
26.5\end{array}$ & $\begin{array}{l}\mathbf{k g} \\
\mathrm{Ci}\end{array}$ \\
\hline Vanadium & 232 & $\mathrm{mg} / \mathrm{kg}$ & 2,290 & $\mathrm{mg} / \mathrm{kg}$ & $2.4 \times 10^{4}$ & $\mathbf{k g}$ \\
\hline Zinc & 271 & $\mathrm{mg} / \mathrm{kg}$ & 1,610 & $\mathrm{mg} / \mathrm{kg}$ & $2.8 \times 10^{4}$ & kg \\
\hline \multicolumn{7}{|l|}{ Organics } \\
\hline 2-Methylnaphthalene & 31 & $\mu \mathrm{g} / \mathrm{kg}$ & 150 & $\mu \mathrm{g} / \mathrm{kg}$ & 3.2 & $\mathbf{k g}$ \\
\hline Acenaphthene & 16 & $\mu \mathrm{g} / \mathrm{kg}$ & 160 & $\mu \mathrm{g} / \mathrm{kg}$ & 1.6 & kg \\
\hline Acenaphthylene & -(a) & $\mu \mathrm{g} / \mathrm{kg}$ & 64 & $\mu \mathrm{g} / \mathrm{kg}$ & $-(\mathrm{a})$ & \\
\hline Anthracene & 21 & $\mu \mathrm{g} / \mathrm{kg}$ & 200 & $\mu \mathrm{g} / \mathrm{kg}$ & 2.2 & $\mathbf{k g}$ \\
\hline Benzo(a)anthracene & 115 & $\mu \mathrm{g} / \mathrm{kg}$ & 780 & $\mu \mathrm{g} / \mathrm{kg}$ & 11.8 & $\mathbf{k g}$ \\
\hline Benzo(b)fluoranthene & 107 & $\mu \mathrm{g} / \mathrm{kg}$ & 990 & $\mu \mathrm{g} / \mathrm{kg}$ & 11.0 & $\mathbf{k g}$ \\
\hline Benzo(k)fluoranthene & 75 & $\mu \mathrm{g} / \mathrm{kg}$ & 920 & $\mu \mathrm{g} / \mathrm{kg}$ & 7.7 & $\mathbf{k g}$ \\
\hline Benzo(g,h,i)perylene & 75 & $\mu \mathrm{g} / \mathrm{kg}$ & 960 & $\mu \mathrm{g} / \mathrm{kg}$ & 7.7 & $\mathbf{k g}$ \\
\hline Benzo(a)pyrene & 88 & $\mu \mathrm{g} / \mathrm{kg}$ & 820 & $\mu \mathrm{g} / \mathrm{kg}$ & 9.0 & $\mathbf{k g}$ \\
\hline Bensoic Acid & -(a) & $\mu \mathrm{g} / \mathrm{kg}$ & 700 & $\mu \mathrm{g} / \mathrm{kg}$ & $-(\mathrm{a})$ & \\
\hline Bis(2-ethylhexyl)phthalate & 352 & $\mu g / \mathbf{k g}$ & 1,500 & $\mu \mathrm{g} / \mathrm{kg}$ & 36.2 & $\mathbf{k g}$ \\
\hline Chloroform & -(a) & & 1.3 & $\mu \mathrm{g} / \mathrm{kg}$ & -(a) & \\
\hline Chrysene & 156 & $\mu g / \mathrm{kg}$ & 1,100 & $\mu \mathrm{g} / \mathrm{kg}$ & 16.0 & $\mathbf{k g}$ \\
\hline Dibenzofuran & -(a) & $\mu \mathrm{g} / \mathrm{kg}$ & 92 & $\mu \mathrm{g} / \mathrm{kg}$ & -(a) & \\
\hline Diethylphthalate & $-(a)$ & $\mu \mathrm{g} / \mathrm{kg}$ & 68 & $\mu \mathrm{g} / \mathrm{kg}$ & -(a) & \\
\hline Di-n-Butylphthalate & 82. & $\mu \mathrm{g} / \mathrm{kg}$ & 260 & $\mu \mathrm{g} / \mathrm{kg}$ & 8.4 & $\mathbf{k g}$ \\
\hline Ethylbenzene & -(a) & $\mu \mathrm{g} / \mathrm{kg}$ & 3.4 & $\mu \mathrm{g} / \mathrm{kg}$ & -(a) & \\
\hline Fluoranthene & 359 & $\mu \mathrm{g} / \mathrm{kg}$ & 1,000 & $\mu \mathrm{g} / \mathrm{kg}$ & 36.9 & $\mathbf{k g}$ \\
\hline Fluorene & 82 & $\mu \mathrm{g} / \mathrm{kg}$ & 1,300 & $\mu \mathrm{g} / \mathrm{kg}$ & 8.4 & $\mathbf{k g}$ \\
\hline Indeno $(1,2,3-c d)$ pyrene & 25 & $\mu \mathrm{g} / \mathrm{kg}$ & 260 & $\mu \mathrm{g} / \mathrm{kg}$ & 2.6 & $\mathbf{k g}$ \\
\hline Methylene Chloride & -(a) & $\mu \mathrm{g} / \mathrm{kg}$ & 8,000 & $\mu \mathrm{g} / \mathrm{kg}$ & -(a) & \\
\hline Naphthalene & 27 & $\mu \mathrm{g} / \mathrm{kg}$ & 120 & $\mu \mathrm{g} / \mathrm{kg}$ & 2.8 & $\mathbf{k g}$ \\
\hline Phenanthrene & 175 & $\mu \mathrm{g} / \mathrm{kg}$ & $1,100^{\circ}$ & $\mu \mathrm{g} / \mathrm{kg}$ & 18.0 & $\mathbf{k g}$ \\
\hline Pyrene & 194 & $\mu \mathrm{g} / \mathrm{kg}$ & 1,600 & $\mu \mathrm{g} / \mathrm{kg}$ & 19.9 & kg \\
\hline Tetrachloroethene & 92 & $\mu \mathrm{g} / \mathrm{kg}$ & 1,700 & $\mu \mathrm{g} / \mathrm{kg}$ & 9.5 & $\mathbf{k g}$ \\
\hline Toluene & 7.6 & $\mu \mathrm{g} / \mathrm{kg}$ & 57 & $\mu \mathrm{g} / \mathrm{kg}$ & 0.78 & $\mathbf{k g}$ \\
\hline
\end{tabular}

(a) Contaminant detected in only one sample; consequently, no average concentration calculated.

(b) Values calculated from measured data for U-238 assuming that U-238 contributes $47.3 \%$, U-234 contributes $50.5 \%$, and U-235 contributes $2.2 \%$ of the total activity of natural uranium. 
For all of the metals (except uranium) and organics, the total inventory present in the soil was estimated by multiplying the average concentration by the volume of contaminated soil provided in Table A.1 (assuming an average bulk soil density of 1.6 grams per cubic centimeter). This same approach was used to estimate the inventory for Ra-226, Th-230, and Th-232.

A total of $7,250 \mathrm{t}$ of ore refinery residues, containing approximately $0.54 \%$ uranium oxide, were disposed of on this property. This translates into approximately $39,100 \mathrm{~kg}$, or $26.5 \mathrm{Ci}$, of natural uranium. Because U-238 contributes approximately $47.3 \%$, U-235 approximately $2.2 \%$, and U-234 approximately $50.5 \%$ of the total activity of natural uranium, these percentages were multiplied by $26.5 \mathrm{Ci}$ to estimate the total inventory for these radioisotopes, as shown in Table A.2.

The top 2.1 meters of contaminated soil, the average thickness of the disposed ore refinery residues, is assumed to have the average radionuclide concentrations provided in Table A.2. The concentration profile of each radionuclide in the natural soil column below a depth of 2.1 meters was estimated using a onedimensional contaminant transport model that used the environmental parameters for the environmental setting described below. The results of this effort are presented in Table A.3.

The organic constituents were all assumed to have been discharged onto the surface of the radioactively-contaminated ore refinery residue soil. The concentration profile for each of these constituents, with depth below the ground surface, is provided in Table A.4. These profiles were estimated using the one-dimensional contaminant transport model discussed above. 
TABLE A.3. Concentration Profile of Radionuclides in the Soil Column

\begin{tabular}{|c|c|c|c|c|c|c|c|c|}
\hline \multirow[b]{2}{*}{$\begin{array}{c}\text { Inventory } \\
\text { Fraction (\%) }\end{array}$} & \multicolumn{4}{|c|}{ U-238 } & \multicolumn{4}{|c|}{ U-235 } \\
\hline & $\begin{array}{c}\text { Depth } \\
(\mathrm{cm})\end{array}$ & $\begin{array}{c}\text { Concentration } \\
(\mathrm{pCi} / \mathrm{g})\end{array}$ & $\begin{array}{c}\text { Inventory } \\
\text { (Ci) }\end{array}$ & $\begin{array}{c}\text { Soil Volume } \\
\left(\mathrm{m}^{3}\right)\end{array}$ & $\begin{array}{l}\text { Depth } \\
(\mathrm{cm})\end{array}$ & $\begin{array}{c}\text { Concentration } \\
(\mathbf{p C i} / \mathrm{g})\end{array}$ & $\begin{array}{c}\text { Inventory } \\
\text { (Ci) }\end{array}$ & \begin{tabular}{|c} 
Soil Volume \\
$\left(\mathrm{m}^{3}\right)$
\end{tabular} \\
\hline 0.0 &.- & $1.4 \times 10^{4}$ & -- & - & - & $6.3 \times 10^{2}$ & - & - \\
\hline 50.0 & 1.3 & $8.7 \times 10^{3}$ & 6.3 & 370 & 1.3 & $4.1 \times 10^{2}$ & 0.29 & 370 \\
\hline 90.0 & 3.4 & $2.8 \times 10^{3}$ & 1.1 .2 & 990 & 3.4 & $1.3 \times 10^{2}$ & 0.52 & 990 \\
\hline 99.0 & 5.9 & $3.2 \times 10^{2}$ & 12.4 & 1,700 & 5.9 & $1.5 \times 10^{1}$ & 0.57 & 1,700 \\
\hline 99.0 & 7.6 & $4.6 \times 10^{1}$ & 12.5 & 2,200 & 7.6 & 2.1 & 0.58 & 2,200 \\
\hline \multirow[t]{2}{*}{100.0} & 12.2 & $2.3 \times 10^{-2}$ & 12.5 & 3,600 & 12.2 & $1.1 \times 10^{-3}$ & 0.58 & 3,600 \\
\hline & \multicolumn{4}{|c|}{ U-234 } & \multicolumn{4}{|c|}{ Th-232 } \\
\hline $\begin{array}{c}\text { Inventory } \\
\text { Fraction (\%) }\end{array}$ & $\begin{array}{c}\text { Depth } \\
(\mathrm{cm})\end{array}$ & $\begin{array}{c}\text { Concentration } \\
(\mathrm{pCi} / \mathrm{g})\end{array}$ & $\begin{array}{c}\text { Inventory } \\
\text { (Ci) }\end{array}$ & \begin{tabular}{|c|}
$\begin{array}{c}\text { Soil Volume } \\
\left(\mathrm{m}^{3}\right)\end{array}$ \\
\end{tabular} & $\begin{array}{l}\text { Depth } \\
\text { (cm) }\end{array}$ & $\begin{array}{c}\text { Concentration } \\
(\mathrm{pCi} / \mathrm{g})\end{array}$ & \begin{tabular}{|c|} 
Inventory \\
(Ci)
\end{tabular} & $\begin{array}{c}\text { Soil Volume } \\
\left(\mathrm{m}^{3}\right)\end{array}$ \\
\hline 0.0 & - & $1.5 \times 10^{4}$ & - & - & - & $4.4 \times 10^{2}$ & -- & -- \\
\hline 50.0 & 1.3 & $9.4 \times 10^{3}$ & 6.7 & 370 & 0.5 & $2.5 \times 10^{2}$ & 0.07 & 150 \\
\hline 90.0 & 3.4 & $3.0 \times 10^{3}$ & 12.1 & 990 & 1.3 & $7.3 \times 10^{1}$ & 0.13 & 390 \\
\hline 99.0 & 5.9 & $3.4 \times 10^{2}$ & 13.3 & 1,700 & 2.3 & 8.5 & 0.14 & 680 \\
\hline 99.0 & 7.6 & $4.9 \times 10^{1}$ & 13.4 & 2,200 & 3.0 & 1.3 & 0.14 & 870 \\
\hline \multirow[t]{2}{*}{100.0} & 12.2 & $2.5 \times 10^{-2}$ & 13.4 & 3,600 & 5.1 & $2.7 \times 10^{-4}$ & 0.14 & 1,500 \\
\hline & \multicolumn{4}{|c|}{ Th-230 } & \multicolumn{4}{|c|}{$\mathrm{Ra}-226$} \\
\hline $\begin{array}{c}\text { Inventory } \\
\text { Fraction (\%) }\end{array}$ & \begin{tabular}{|c|} 
Depth \\
$(\mathrm{cm})$
\end{tabular} & $\begin{array}{c}\text { Concentration } \\
(\mathrm{pCi} / \mathrm{g})\end{array}$ & $\begin{array}{c}\text { Inventory } \\
\text { (Ci) }\end{array}$ & \begin{tabular}{|c|}
$\begin{array}{c}\text { Soil Volume } \\
\left(\mathrm{m}^{3}\right)\end{array}$ \\
\end{tabular} & $\begin{array}{l}\text { Depth } \\
(\mathrm{cm})\end{array}$ & \begin{tabular}{|c|}
$\begin{array}{c}\text { Concentration } \\
(\mathrm{pCi} / \mathrm{g})\end{array}$ \\
\end{tabular} & $\begin{array}{c}\text { Inventory } \\
\text { (Ci) }\end{array}$ & \begin{tabular}{|c}
$\begin{array}{c}\text { Soil Volume } \\
\left(\mathrm{m}^{3}\right)\end{array}$ \\
\end{tabular} \\
\hline 0.0 & - & $7.6 \times 10^{4}$ & - & - & - & $5.7 \times 10^{2}$ & - & - \\
\hline 50.0 & 0.5 & $4.4 \times 10^{4}$ & 12.2 & 150 & 3.9 & $3.8 \times 10^{2}$ & 0.75 & 1,100 \\
\hline 90.0 & 1.3 & $1.3 \times 10^{4}$ & 21.9 & 390 & 8.8 & $1.3 \times 10^{2}$ & 1.4 & 2,600 \\
\hline 99.0 & 2.3 & $1.5 \times 10^{3}$ & 24.1 & 680 & 13.6 & $1.9 \times 10^{1}$ & 1.5 & 4,000 \\
\hline 99.0 & 3.0 & $2.3 \times 10^{2}$ & 24.3 & 870 & 18.5 & 1.3 & 1.5 & 5,400 \\
\hline 100.0 & 5.0 & $1.0 \times 10^{-1}$ & 24.3 & 1,500 & 27.3 & $1.0 \times 10^{-3}$ & 1.5 & 8,000 \\
\hline
\end{tabular}




\section{TABLE A.4. Concentration Profile of Organics in the Soil Column}

\begin{tabular}{|c|c|c|c|c|c|c|c|c|}
\hline & \multicolumn{4}{|c|}{ Toluene } & \multicolumn{4}{|c|}{ Bis(2-Ethylhexyl) Phthalate } \\
\hline $\begin{array}{l}\text { Inventory } \\
\text { Fraction (\%) }\end{array}$ & $\begin{array}{c}\text { Depth } \\
\text { (m) }\end{array}$ & $\begin{array}{c}\text { Concentration } \\
(\mu \mathrm{g} / \mathrm{kg})\end{array}$ & $\begin{array}{c}\text { Inventory } \\
(\mathrm{kg})\end{array}$ & $\begin{array}{c}\text { Soil Volume } \\
\left(\mathrm{m}^{3}\right)\end{array}$ & $\begin{array}{l}\text { Depth } \\
\text { (cm) }\end{array}$ & $\begin{array}{c}\text { Concentration } \\
(\mu \mathrm{g} / \mathrm{kg})\end{array}$ & $\begin{array}{c}\text { Inventory } \\
(\mathrm{kg})\end{array}$ & $\begin{array}{c}\text { Soil Volume } \\
\left(\mathrm{m}^{3}\right)\end{array}$ \\
\hline 0.0 & - & $1.6 \times 10^{1}$ & -- & - & - & $5.1 \times 10^{4}$ & - & - \\
\hline 50.0 & 0.6 & $2.4 \times 10^{1}$ & 0.39 & $1.75 \times 10^{4}$ & 0.8 & $4.8 \times 10^{4}$ & 18.1 & 240 \\
\hline 90.0 & 1.0 & $1.0 \times 10^{1}$ & 0.71 & $2.92 \times 10^{4}$ & 1.8 & $1.5 \times 10^{4}$ & 32.6 & 540 \\
\hline 99.0 & 1.3 & 2.0 & 0.77 & $3.65 \times 10^{4}$ & 3.0 & $1.6 \times 10^{3}$ & 35.8 & 890 \\
\hline 99.0 & 1.5 & $2.5 \times 10^{-1}$ & 0.78 & $4.24 \times 10^{4}$ & 3.9 & $2.2 \times 10^{2}$ & 36.2 & 1,100 \\
\hline 100.0 & 2.0 & $6.9 \times 10^{-5}$ & 0.78 & $5.70 \times 10^{4}$ & 6.1 & $1.5 \times 10^{-1}$ & 36.2 & 1,800 \\
\hline & \multicolumn{4}{|c|}{ Anthracene } & \multicolumn{4}{|c|}{ Tetrachloroethene } \\
\hline $\begin{array}{c}\text { Inventory } \\
\text { Fraction (\%) }\end{array}$ & $\begin{array}{c}\text { Depth } \\
\text { (cm) }\end{array}$ & $\begin{array}{c}\text { Concentration } \\
(\mu \mathrm{g} / \mathrm{kg})\end{array}$ & $\begin{array}{c}\text { Inventory } \\
\text { (kg) }\end{array}$ & $\begin{array}{c}\text { Soil Volume } \\
\left(\mathbf{m}^{3}\right)\end{array}$ & $\begin{array}{c}\text { Depth } \\
\text { (m) }\end{array}$ & $\begin{array}{c}\text { Concentration } \\
(\mu \mathrm{g} / \mathrm{kg})\end{array}$ & $\begin{array}{c}\text { Inventory } \\
(\mathrm{kg})\end{array}$ & $\begin{array}{c}\text { Soil Volume } \\
\left(\mathrm{m}^{3}\right)\end{array}$ \\
\hline 0.0 & - & $7.7 \times 10^{2}$ & - & -- & -- & 4.4 & -- & - \\
\hline 50.0 & 2.3 & $1.1 \times 10^{3}$ & 1.0 & 670 & 0.5 & $3.4 \times 10^{2}$ & 4.7 & $1.46 \times 10^{4}$ \\
\hline 90.0 & 5.1 & $3.7 \times 10^{2}$ & 1.9 & 1,500 & 0.85 & $1.4 \times 10^{1}$ & 8.7 & $2.48 \times 10^{4}$ \\
\hline 99.0 & 8.6 & $3.7 \times 10^{1}$ & 2.2 & 2,500 & 1.1 & $2.1 \times 10^{1}$ & 9.4 & $3.21 \times 10^{4}$ \\
\hline 99.0 & 10.9 & 4.4 & 2.2 & 3,200 & 1.3 & 3.5 & 9.5 & $3.65 \times 10^{4}$ \\
\hline 100.0 & 16.6 & $2.8 \times 10^{-3}$ & 2.2 & 4,900 & 1.7 & $1.1 \times 10^{-3}$ & 9.5 & $4.97 \times 10^{4}$ \\
\hline & \multicolumn{4}{|c|}{ Pyrene } & \multicolumn{4}{|c|}{ Indeno $(1,2,3-C D)$ Pyrene } \\
\hline $\begin{array}{c}\text { Inventory } \\
\text { Fraction (\%) }\end{array}$ & $\begin{array}{c}\text { Depth } \\
(\mathrm{cm})\end{array}$ & $\begin{array}{c}\text { Concentration } \\
(\mu \mathrm{g} / \mathrm{kg})\end{array}$ & $\begin{array}{c}\text { Inventory } \\
\text { (kg) }\end{array}$ & \begin{tabular}{|c|}
$\begin{array}{c}\text { Soil Volume } \\
\left(\mathrm{m}^{\mathbf{3}}\right)\end{array}$ \\
\end{tabular} & $\begin{array}{l}\text { Depth } \\
\text { (cm) }\end{array}$ & $\begin{array}{c}\text { Concentration } \\
(\mu \mathrm{k} / \mathrm{kg})\end{array}$ & $\begin{array}{c}\text { Inventory } \\
(\mathrm{kg})\end{array}$ & $\begin{array}{c}\text { Soil Volume } \\
\left(\mathrm{m}^{3}\right)\end{array}$ \\
\hline 0.0 & - & $2: 2 \times 10^{4}$ & - & - & - & $7.4 \times 10^{2}$ & - & - \\
\hline 50.0 & 1.0 & $1.4 \times 10^{4}$ & 10.0 & 280 & 0.13 & $4.1 \times 10^{2}$ & 1.4 & 40 \\
\hline 90.0 & 2.6 & $4.2 \times 10^{3}$ & 17.9 & 750 & 0.35 & $1.1 \times 10^{2}$ & 2.3 & 100 \\
\hline 99.0 & 4.5 & $4.8 \times 10^{2}$ & 19.7 & 1,300 & 0.62 & $1.3 \times 10^{1}$ & 2.6 & 180 \\
\hline 99.0 & 5.8 & $7.1 \times 10^{1}$ & 19.9 & 1,700 & 0.84 & 1.3 & 2.6 & 250 \\
\hline 100.0 & 9.3 & $4.5 \times 10^{-2}$ & 19.9 & 2,700 & 1.3 & $1.4 \times 10^{-3}$ & 2.6 & 390 \\
\hline & \multicolumn{4}{|c|}{ Benzo(b)Fluoranthene } & \multicolumn{4}{|c|}{ Fluoranthene } \\
\hline $\begin{array}{c}\text { Inventory } \\
\text { Fraction (\%) }\end{array}$ & $\begin{array}{c}\text { Depth } \\
(\mathrm{cm})\end{array}$ & $\begin{array}{c}\text { Concentration } \\
(\mu \mathrm{g} / \mathrm{kg})\end{array}$ & $\begin{array}{c}\text { Inventory } \\
\text { (kg) }\end{array}$ & $\begin{array}{c}\begin{array}{c}\text { Soil Volume } \\
\left(\mathrm{m}^{3}\right)\end{array} \\
\end{array}$ & $\begin{array}{l}\text { Depth } \\
\text { (cm) }\end{array}$ & $\begin{array}{c}\text { Concentration } \\
(\mu \mathrm{k} / \mathrm{kg})\end{array}$ & $\begin{array}{c}\text { Inventory } \\
(\mathrm{kg})\end{array}$ & $\begin{array}{c}\text { Soil Volume } \\
\left(\mathrm{m}^{3}\right)\end{array}$ \\
\hline 0.0 & - & $1.1 \times 10^{4}$ & - & - & - & $4.3 \times 10^{4}$ & - & - \\
\hline 50.0 & 0.23 & $6.2 \times 10^{3}$ & 5.5 & 70 & 1.0 & $2.7 \times 10^{4}$ & 18.5 & 280 \\
\hline 90.0 & 0.61 & $1.7 \times 10^{3}$ & 9.9 & 180 & 2.6 & $8.2 \times 10^{3}$ & 33.2 & 750 \\
\hline 99.0 & 1.1 & $2.0 \times 10^{2}$ & 10.9 & 310 & 4.5 & $9.5 \times 10^{2}$ & 36.5 & 1,300 \\
\hline 99.0 & 1.5 & $2.0 \times 10^{1}$ & 11.0 & 430 & 5.8 & $1.4 \times 10^{2}$ & 36.9 & 1,700 \\
\hline 100.0 & 2.4 & $8.9 \times 10^{-3}$ & 11.0 & 700 & 9.3 & $8.9 \times 10^{-2}$ & 36.9 & 2,700 \\
\hline
\end{tabular}


TABLE A.4. (contd)

\begin{tabular}{|c|c|c|c|c|c|c|c|c|}
\hline & \multicolumn{4}{|c|}{ Benzo(k)Fluoranthene } & \multicolumn{4}{|c|}{ Chrysene } \\
\hline $\begin{array}{c}\text { Inventory } \\
\text { Fraction (\%) }\end{array}$ & \begin{tabular}{|c} 
Depth \\
$(\mathrm{cm})$
\end{tabular} & \begin{tabular}{|c|}
$\begin{array}{c}\text { Concentration } \\
(\mu \mathrm{k} / \mathrm{kg})\end{array}$ \\
\end{tabular} & $\begin{array}{c}\text { Inventory } \\
(\mathrm{kg})\end{array}$ & \begin{tabular}{|c|}
$\begin{array}{c}\text { Soil Volume } \\
\left(\mathrm{m}^{3}\right)\end{array}$ \\
\end{tabular} & $\begin{array}{l}\text { Depth } \\
(\mathrm{cm})\end{array}$ & $\begin{array}{c}\text { Concentration } \\
(\mu \mathrm{g} / \mathrm{kg})\end{array}$ & $\begin{array}{c}\text { Inventory } \\
\text { (kg) }\end{array}$ & $\begin{array}{c}\text { Soil Volume } \\
\left(\mathrm{m}^{3}\right)\end{array}$ \\
\hline 0.0 & - & $1.1 \times 10^{4}$ & -- & -- & - & $4.3 \times 10^{4}$ & -- & -- \\
\hline 50.0 & 0.23 & $6.2 \times 10^{3}$ & 5.5 & 70 & 1.0 & $2.7 \times 10^{4}$ & 18.5 & 280 \\
\hline 90.0 & 0.61 & $1.7 \times 10^{3}$ & 9.9 & 180 & 2.6 & $8.2 \times 10^{3}$ & 33.2 & 750 \\
\hline 99.0 & 1.1 & $2.0 \times 10^{2}$ & 10.9 & 310 & 4.5 & $9.5 \times 10^{2}$ & 36.5 & 1,300 \\
\hline 99.0 & 1.5 & $2.0 \times 10^{1}$ & 11.0 & 430 & 5.8 & $1.4 \times 10^{2}$ & 36.9 & 1,700 \\
\hline 100.0 & 2.4 & $8.9 \times 10^{-3}$ & 11.0 & 700 & 9.3 & $8.9 \times 10^{-2}$ & 36.9 & 2,700 \\
\hline & \multicolumn{4}{|c|}{ Benzo(a)Pyrene } & \multicolumn{4}{|c|}{ Benzo(a)Anthracene } \\
\hline $\begin{array}{c}\text { Inventory } \\
\text { Fraction (\%) }\end{array}$ & $\begin{array}{c}\text { Depth } \\
(\mathrm{cm})\end{array}$ & $\begin{array}{c}\text { Concentration } \\
(\mu \mathrm{g} / \mathrm{kg})\end{array}$ & $\begin{array}{c}\text { Inventory } \\
(\mathrm{kg})\end{array}$ & \begin{tabular}{|c|}
$\begin{array}{c}\text { Soil Volume } \\
\left(\mathrm{m}^{3}\right)\end{array}$ \\
\end{tabular} & $\begin{array}{l}\text { Depth } \\
(\mathrm{cm})\end{array}$ & $\begin{array}{c}\text { Concentration } \\
(\mu \mathrm{g} / \mathrm{kg})\end{array}$ & $\begin{array}{c}\text { Inventory } \\
(\mathrm{kg})\end{array}$ & $\begin{array}{c}\text { Soil Volume } \\
\left(\mathrm{m}^{3}\right)\end{array}$ \\
\hline 0.0 & -- & $1.0 \times 10^{4}$ & -- & -- & - & $7.4 \times 10^{3}$ & -- & -- \\
\hline 50.0 & 0.07 & $5.5 \times 10^{3}$ & 4.8 & 20 & 0.14 & $4.1 \times 10^{3}$ & 6.3 & 40 \\
\hline 90.0 & 0.19 & $1.5 \times 10^{3}$ & 8.1 & 60 & 0.38 & $1.1 \times 10^{3}$ & 10.6 & 110 \\
\hline 99.0 & 0.33 & $1.8 \times 10^{2}$ & 8.9 & 100 & 0.67 & $1.3 \times 10^{2}$ & 11.7 & 200 \\
\hline 99.0 & 0.45 & $1.8 \times 10^{1}$ & 9.0 & 130 & 0.91 & $1.3 \times 10^{1}$ & 11.8 & 270 \\
\hline 100.0 & 0.71 & $2.0 \times 10^{-2}$ & 9.0 & 210 & 1.4 & $1.4 \times 10^{-2}$ & 11.8 & 420 \\
\hline & \multicolumn{4}{|c|}{ Acenaphthene } & \multicolumn{4}{|c|}{ Di-n-butylphthalate } \\
\hline $\begin{array}{c}\text { Inventory } \\
\text { Fraction (\%) } \\
\end{array}$ & $\begin{array}{l}\text { Depth } \\
(\mathrm{cm})\end{array}$ & $\begin{array}{c}\text { Concentration } \\
(\mu \mathrm{g} / \mathrm{kg})\end{array}$ & $\begin{array}{c}\text { Inventory } \\
(\mathrm{kg})\end{array}$ & \begin{tabular}{|c|}
$\begin{array}{c}\text { Soil Volume } \\
\left(\mathrm{m}^{3}\right)\end{array}$ \\
\end{tabular} & $\begin{array}{l}\text { Depth } \\
\text { (cm) }\end{array}$ & $\begin{array}{c}\text { Concentration } \\
(\mu \mathrm{g} / \mathrm{kg})\end{array}$ & \begin{tabular}{|c|} 
Inventory \\
$(\mathrm{kg})$
\end{tabular} & $\begin{array}{c}\begin{array}{c}\text { Soil Volume } \\
\left(\mathrm{m}^{3}\right)\end{array} \\
\end{array}$ \\
\hline 0.0 & - & $1.7 \times 10^{2}$ & - & - & - & $1.8 \times 10^{4}$ & -- & - \\
\hline 50.0 & 5.7 & $3.6 \times 10^{2}$ & 0.83 & 1,700 & 0.57 & $1.6 \times 10^{4}$ & 4.2 & 170 \\
\hline 90.0 & 11.3 & $1.2 \times 10^{2}$ & 1.4 & 3,300 & 1.3 & $4.9 \times 10^{3}$ & 7.6 & 370 \\
\hline 99.0 & 17.0 & $1.5 \times 10^{1}$ & 1.6 & 5,000 & 2.1 & $5.1 \times 10^{2}$ & 8.3 & 620 \\
\hline 99.0 & 21.6 & 1.5 & 1.6 & 6,300 & 2.7 & $7.4 \times 10^{1}$ & 8.4 & 790 \\
\hline 100.0 & 30.6 & $2.6 \times 10^{-3}$ & 1.6 & 9,000 & 4.3 & $5.9 \times 10^{-2}$ & 8.4 & 1,300 \\
\hline & \multicolumn{4}{|c|}{ Phenanthrene } & \multicolumn{4}{|c|}{ Fluorene } \\
\hline $\begin{array}{c}\text { Inventory } \\
\text { Fraction (\%) }\end{array}$ & \begin{tabular}{|} 
Depth \\
$(\mathrm{cm})$
\end{tabular} & $\begin{array}{c}\text { Concentration } \\
(\mu \mathrm{g} / \mathrm{kg})\end{array}$ & $\begin{array}{c}\text { Inventory } \\
(\mathrm{kg})\end{array}$ & \begin{tabular}{|c|}
$\begin{array}{c}\text { Soil Volume } \\
\left(\mathrm{m}^{3}\right)\end{array}$ \\
\end{tabular} & $\begin{array}{c}\text { Depth } \\
(\mathrm{cm})\end{array}$ & $\begin{array}{c}\text { Concentration } \\
(\mu \mathrm{g} / \mathrm{kg})\end{array}$ & $\begin{array}{c}\text { Inventory } \\
(\mathbf{k g})\end{array}$ & $\begin{array}{c}\text { Soil Volume } \\
\left(\mathrm{m}^{3}\right)\end{array}$ \\
\hline 0.0 & -- & $6.3 \times 10^{3}$ & -- & - & - & $1.6 \times 10^{3}$ & -- & - \\
\hline 50.0 & 2.3 & $8.6 \times 10^{3}$ & 8.5 & 670 & 4.2 & $2.5 \times 10^{3}$ & 4.6 & 1,200 \\
\hline 90.0 & 5.1 & $3.0 \times 10^{3}$ & 15.9 & 1,500 & 8.5 & $7.7 \times 10^{2}$ & 7.6 & 2,500 \\
\hline 99.0 & 8.6 & $3.0 \times 10^{2}$ & 17.9 & 2,500 & 12.7 & $1.0 \times 10^{2}$ & 8.3 & 3,700 \\
\hline 99.0 & 10.9 & $3.6 \times 10^{1}$ & 18.0 & 3,200 & 16.1 & $1.1 \times 10^{1}$ & 8.4 & 4,700 \\
\hline 100.0 & 16.6 & $2.3 \times 10^{-2}$ & 18.0 & 4,900 & 24.6 & $4.2 \times 10^{-3}$ & 8.4 & 7,200 \\
\hline
\end{tabular}


TABLE A.4. (contd)

\begin{tabular}{|c|c|c|c|c|c|c|c|c|}
\hline & \multicolumn{4}{|c|}{ Phenanthrene } & \multicolumn{4}{|c|}{ Fluorene } \\
\hline $\begin{array}{c}\text { Inventory } \\
\text { Fraction (\%) }\end{array}$ & $\begin{array}{c}\text { Depth } \\
\text { (m) }\end{array}$ & $\begin{array}{c}\text { Concentration } \\
(\mu \mathrm{g} / \mathrm{kg})\end{array}$ & $\begin{array}{c}\text { Inventory } \\
(\mathrm{kg})\end{array}$ & $\begin{array}{c}\text { Soil Volume } \\
\left(\mathrm{m}^{3}\right)\end{array}$ & $\begin{array}{c}\text { Depth } \\
\text { (cm) }\end{array}$ & $\begin{array}{c}\text { Concentration } \\
(\mu \mathrm{g} / \mathrm{kg})\end{array}$ & $\begin{array}{c}\text { Inventory } \\
\text { (kg) }\end{array}$ & $\begin{array}{c}\text { Soil Volume } \\
\left(\mathrm{m}^{3}\right)\end{array}$ \\
\hline 0.0 & $-\ldots$ & $2.1 \times 10^{1}$ & - & - & - & $3.3 \times 10^{2}$ & - & - \\
\hline 50.0 & 0.20 & $2.2 \times 10^{2}$ & 1.3 & $5.9 \times 10^{3}$ & 5.8 & $7.1 \times 10^{2}$ & 1.7 & 1,700 \\
\hline 90.0 & 0.37 & $8.5 \times 10^{1}$ & 2.5 & $1.1 \times 10^{4}$ & 11.6 & $2.4 \times 10^{2}$ & 2.9 & 3,400 \\
\hline 99.0 & 0.50 & $1.5 \times 10^{1}$ & 2.8 & $1.5 \times 10^{4}$ & 17.3 & $3.1 \times 10^{1}$ & 3.2 & 5,100 \\
\hline 99.0 & 0.64 & 1.0 & 2.8 & $1.9 \times 10^{4}$ & 22.0 & 3.0 & 3.2 & 6,400 \\
\hline 100.0 & 0.87 & $8.8 \times 10^{-4}$ & 2.8 & $2.6 \times 10^{4}$ & 32.4 & $1.9 \times 10^{-3}$ & 3.2 & 9,500 \\
\hline
\end{tabular}

Each of the metals shown in Table A.2 is assumed to be evenly distributed throughout the ore refinery residue zone and was not analyzed to determine the extent of transport into the natural soil column, because the radionuclides and the organics were assumed to be the primary contaminants of concern.

\section{Environmental Setting}

The environmental setting for this contaminated soil site is provided in Section A.2.

\section{A.2 Environmental Setting for The Tonwanda Site}

The Tonawanda installation consists of four separate properties covering a total of 354 acres in the town of Tonawanda, New York. Ecologically, the Tonawanda site lies within the beech-maple forest section of the eastern deciduous forest division. The predominant forest cover type in this area is ash-elm-maple surrounded by a maple-beech-birch cover type.

Tonawanda is located near the transition between humid continental warm summer and cool summer climatic regimes (see Table A.5 for detailed climatic 


\section{TABLE A.5. Ashland 1 Average Local Climatology}

Greater Buffalo International Airport, Buffalo, New York

Elevation:

Latitude:

Annual mean air temp:(a)

Anemometer height:(a)

Mean annual wind speed:(a)

Fastest $1-\min$ wind speed:(a)

Annual precipitation:(a)

Precipitation days: ${ }^{(a)}$

Thunderstorm freq: $:^{(a)}$

Avg. morning mixing ht: ${ }^{(b)}$

Avg. afternoon mixing ht:(b)

Topsoil moisture capacity:(b)
$215 \mathrm{~m}$

$42.93^{\circ} \mathrm{N}$

$47.6^{\circ} \mathrm{F}$

$10.0 \mathrm{~m}$

$23 \mathrm{mph}$

$91 \mathrm{mph}$

37.5 in

$169 \mathrm{yr}$

$31 \mathrm{yr}$

$600 \mathrm{~m}$

$1300 \mathrm{~m}$

$0.35 \mathrm{~cm}$

\begin{tabular}{|c|c|c|c|c|c|c|c|c|}
\hline \multirow{2}{*}{\multicolumn{2}{|c|}{ Month }} & \multicolumn{5}{|c|}{ Monthly Averages } & \multicolumn{2}{|c|}{ Daily RH } \\
\hline & & $\begin{array}{c}\text { Temp. } \\
\left({ }^{\circ} \mathrm{F}\right)\end{array}$ & $\begin{array}{l}\text { Precip. } \\
\text { (inches) }\end{array}$ & $\begin{array}{l}\text { Wind } \\
\text { Speed } \\
(\text { mph })\end{array}$ & $\begin{array}{c}\text { Cloud } \\
\text { Cover } \\
\text { (tenths) }\end{array}$ & $\begin{array}{c}\text { Precip } \\
\text { Days (\#) }\end{array}$ & $\operatorname{Max}(\%)$ & Min (\%) \\
\hline Jan & & 24 & 3.02 & 14.3 & 8.4 & 20.2 & 79 & 73 \\
\hline Feb & & 25 & 2.40 & 13.7 & 8.2 & 17.0 & 80 & 71 \\
\hline Mar & & 33 & 2.97 & 13.5 & 7.6 & 16.2 & 80 & 66 \\
\hline Apr & & 45 & 3.06 & 12.8 & 7.1 & 14.3 & 76 & 58 \\
\hline May & & 56 & 2.89 & 11.5 & 6.8 & 12.4 & 75 & 56 \\
\hline Jun & & 66 & 2.72 & 11.0 & 6.2 & 10.4 & 77 & 57 \\
\hline Jul & & 71 & 2.96 & 10.4 & 6.0 & 9.9 & 78 & 55 \\
\hline Aug & & 69 & 4.16 & 9.8 & 6.2 & 10.6 & 83 & 58 \\
\hline Sep & & 62 & 3.37 & 10.4 & 6.4 & 10.9 & 84 & 60 \\
\hline Oct & & 52 & 2.93 & 11.1 & 6.7 & 11.4 & 82 & 61 \\
\hline Nov & & 40 & 3.62 & 12.7 & 8.3 & 16.0 & 81 & 70 \\
\hline Dec & & 29 & 3.42 & 13.4 & 8.6 & 19.7 & 81 & 74 \\
\hline (b) & $\begin{array}{l}\text { Me } \\
\text { mea } \\
\text { ave } \\
\text { ave } \\
\text { ME }\end{array}$ & $\begin{array}{l}\text { rologica } \\
\text { Ired ( e.g } \\
\text { ges are b } \\
\text { ges are b } \\
\text { AS Paran }\end{array}$ & $\begin{array}{l}\text { arameters } \\
\text { temperatu } \\
\text { d on a } 30 \\
\text { d on } 26 \mathrm{t} \\
\text { ers (Drop) }\end{array}$ & $\begin{array}{l}\text { present } \\
\text { in }{ }^{\circ} \mathrm{F}, \mathrm{w} \\
\text { ar clima } \\
7 \text { years } \\
\text { et al. } 19\end{array}$ & $\begin{array}{l}\text { using the } \\
\text { d speed in } \\
\text { logically } r \\
\text { data (DO } \\
\text { ): Clima } \\
\text { Precip } \\
\text { Soil ce }\end{array}$ & $\begin{array}{l}\text { its with wh } \\
\text { ph). Temp } \\
\text { esentative } \\
\text { 987). } \\
\text { region inde } \\
\text { ion-evapor } \\
\text { ervation, se }\end{array}$ & $\begin{array}{l}\text { they are ro } \\
\text { ture and pre } \\
\text { od (1951-1s } \\
4 \\
\text { n index: } 11 \\
\text { Curve Nun }\end{array}$ & $\begin{array}{l}\text { inely } \\
\text { ipitation } \\
\text { 0). Other } \\
\text { er: } 71\end{array}$ \\
\hline
\end{tabular}


information). Precipitation averages 38 inches a year. Atmospheric dispersion data are obtained from measurements at the Greater Buffalo International Airport.

The Niagara River is the major surface water feature near the Tonawanda site, receiving drainage from the site via Rattlesnake Creek and Two Mile Creek. Rattlesnake Creek flows northwest about 1.5 miles, crossing both Seaway and Ashland 2 waste sites before joining Two Mile Creek. Two Mile Creek originates south of the Linde site and flows roughly north approximately 2 miles until it empties into the Niagara River. Groundwater at the Tonawanda Site has been observed in three distinct hydrogeologic systems: a perched system, a shallow semi-confined system, and a contact-zone aquifer. The perched system is composed of alluvial fill and its groundwater flow is intermittent, associated with precipitation events. The shallow semi-confined system is composed of sand lenses, and its groundwater discharges to Rattlesnake Creek downstream of the site. Groundwater in the contact-zone aquifer occurs under confined conditions within the coarse-grained basal material and the fractured and jointed upper part of the underlying bedrock. The suspected discharge area for this aquifer is the Niagara River, north-northwest of the site. Refer to Table A.6 for a description of the geohydrology of this site.

Exposure/receptor data, population data, and data on the distribution of agricultural products were not immediately available for this site. These data were compiled by Oak Ridge National Laboratory and are provided in Volume IV. 
TABLE A.6. Geohydrologic Data for Tonawanda

\begin{tabular}{|c|c|c|c|c|c|c|c|c|c|c|}
\hline \multirow[b]{2}{*}{ Layer(s) } & \multirow[b]{2}{*}{ Textural Name } & \multirow[b]{2}{*}{$\begin{array}{c}\text { Thickness } \\
\text { (cm) }\end{array}$} & \multirow[b]{2}{*}{$\begin{array}{c}\text { Bulk } \\
\text { Density } \\
\left(\mathrm{g} / \mathrm{cm}^{3)}\right. \\
\end{array}$} & \multirow[b]{2}{*}{$\begin{array}{c}\text { Total } \\
\text { Porosity } \\
(\%)\end{array}$} & \multirow[b]{2}{*}{$\begin{array}{c}\text { Field } \\
\text { Capacity } \\
(\%) \\
\end{array}$} & \multirow[b]{2}{*}{$\begin{array}{c}\text { Saturated } \\
\text { Hydraulic } \\
\text { Conductivity } \\
\text { (cm/day) } \\
\end{array}$} & \multicolumn{4}{|c|}{ Soil Classification ${ }^{(b)}$} \\
\hline & & & & & & & $\begin{array}{c}\text { Sand } \\
\% \\
\end{array}$ & $\begin{array}{l}\text { Silt } \\
\%\end{array}$ & $\begin{array}{c}\text { Clay } \\
\%\end{array}$ & Organic \% \\
\hline \multicolumn{11}{|c|}{ Shallow Semi-Confined System } \\
\hline PSZ-1 & Sandy Clay Loam ${ }^{(b)}$ & $7.50 \mathrm{E}+01$ & 1.6 & 39.8 & 24 & $4.90 \mathrm{E}+01$ & 60 & 14 & 26 & 0 \\
\hline PSZ-2 & Sandy Clay & $1.10 \mathrm{E}+02$ & 1.51 & 37 & 32 & $8.64 \mathrm{E}+01$ & 50 & 8 & 42 & 0 \\
\hline PSZ-3 & Sandy Clay & $6.20 \mathrm{E}+01$ & 1.51 & 37 & 37 & $8.64 \mathrm{E}+01$ & 50 & 8 & 42 & 0 \\
\hline PSZ-4 & Sandy Clay & $2.52 \mathrm{E}+02$ & 1.51 & 37 & 32 & $8.64 \mathrm{E}-02$ & 50 & 8 & 42 & 0 \\
\hline $\mathrm{sZ}=1$ & $\begin{array}{l}\text { Sandy Clay } \\
\text { Groundwater velocity }=3.24 \mathrm{E}-04 \mathrm{~cm} / \text { day } \\
\text { Effective porosity }=8 \%\end{array}$ & $7.00 \mathrm{E}+02$ & 1.51 & 37 & - & -- & 50 & 8 & 42 & 0 \\
\hline \multicolumn{11}{|c|}{ Storm Flow Zone } \\
\hline PSZ-1 & Sandy Clay Loam & $7.50 \mathrm{E}+01$ & 1.6 & 39.8 & 24 & $4.90 E+01$ & 60 & 14 & 26 & 0 \\
\hline PSZ-2 & Sandy Clay & $1.10 \mathrm{E}+02$ & 1.51 & 37 & 32 & $8.64 E+01$ & 50 & 8 & 42 & 0 \\
\hline SZ-1 & $\begin{array}{l}\text { Sandy Clay } \\
\text { Groundwater Velocity }=0.324 \mathrm{~cm} / \mathrm{day} \\
\text { Effective porosity }=8 \%\end{array}$ & $6.20 \mathrm{E}+01$ & 1.51 & 37 & - & - & 50 & 8 & 42 & 0 \\
\hline sw1 & $\begin{array}{l}\text { Width of river }=1.5 \mathrm{~m} \\
\text { Depth of river }=0.2 \mathrm{~m} \\
\text { Annual average velocity of river }=5 \mathrm{~cm} / \mathrm{s} \\
\text { Discharge rate }=0.015 \mathrm{~m}^{3} / \mathrm{s}\end{array}$ & & & & & & & & & \\
\hline sw2 & $\begin{array}{l}\text { Width of river }=6.1 \mathrm{~m} \\
\text { Depth of river }=0.9 \mathrm{~m} \\
\text { Annual average velocity of river }=3.09 \mathrm{~cm} / \mathrm{s} \\
\text { Discharge rate }=0.169 \mathrm{~m}^{3} / \mathrm{s}\end{array}$ & & & & & & & & & \\
\hline sw3 & $\begin{array}{l}\text { Width of river }=488 \mathrm{~m} \\
\text { Depth of river }=7.6 \mathrm{~m} \\
\text { Annual average velocity of river }=80 \mathrm{~cm} / \mathrm{s} \\
\text { Discharge rate }=2620 \mathrm{~m}^{3} / \mathrm{s}\end{array}$ & & & & & & & & & \\
\hline
\end{tabular}




\section{A.3 ReFERENCES}

A. U.S. Department of Commerce. 1987. Local Climatological Data Annual Summaries for 1986 Part I Eastern Region. National Oceanic and Atmospheric Administration, National Climatic Data Center, Ashville, North Carolina.

B. Droppo, J. G., Jr., D. L. Strenge, J. W. Buck, B. L. Hoopes, R. D. Brockhaus, M. B. Walter, G. Whelan. 1989. Multimedia Environmental Pollutant Assessment System (MEPAS) Application Guidance. Volume 2 Guidelines for Evaluating MEPAS Input Parameters. PNL-7216, Pacific Northwest Laboratory, Richland, Washington. 


\section{Distribution}

No. of

Copies

\section{OFFSITE}

12 DOE/Office of Scientific and Technical Information

L. Oates

ICF/EG\&G

Route 1, Box 1750

Benton City, WA 99320

J. Reisenauer

ICF/Kaiser Engineers

470 B Street

Idaho Falls, ID 83402

R. Coley

Argonne National Laboratory

EID/900 M/S-15

9700 South Cass Avenue

Argonne, IL 60439-4832

T. Lewis

LBA

100 Halsted Street

East Orange, NJ 07019

2 T. Deputy

META/Berger

814 West Diamond Avenue

Suite 101

Gaithersburg, MD 20878
No. of

Copies

W. Wisenbaker

U.S. Department of Energy

Quince Orchard Blvd., EM-43

19901 Germantown Road

Germantown, MD 20874

J. Morris

Oak Ridge National Laboratory

1060 Commerce Park Drive

MS-6480, Rm. 178

Oak Ridge, TN 37830

\section{ONSITE}

DOE Richland Operations Office

T. W. Ferns

A5-19

17 Pacific Northwest Laboratory

J. W. Buck

K6-55

L. L. Clark

K7-97

C. S. Glantz

$\mathrm{K} 6-55$

G. R. Holdren

K6-81

L. R. Huesties

K6-61

M. D. Patridge

M. R. Shay

K7-94

S. M Short (2)

K7-94

G. Whelan

R3-85

M. D. Williams

K6-77

K6-77

Publishing Coordination

Technical Report Files (5) 